
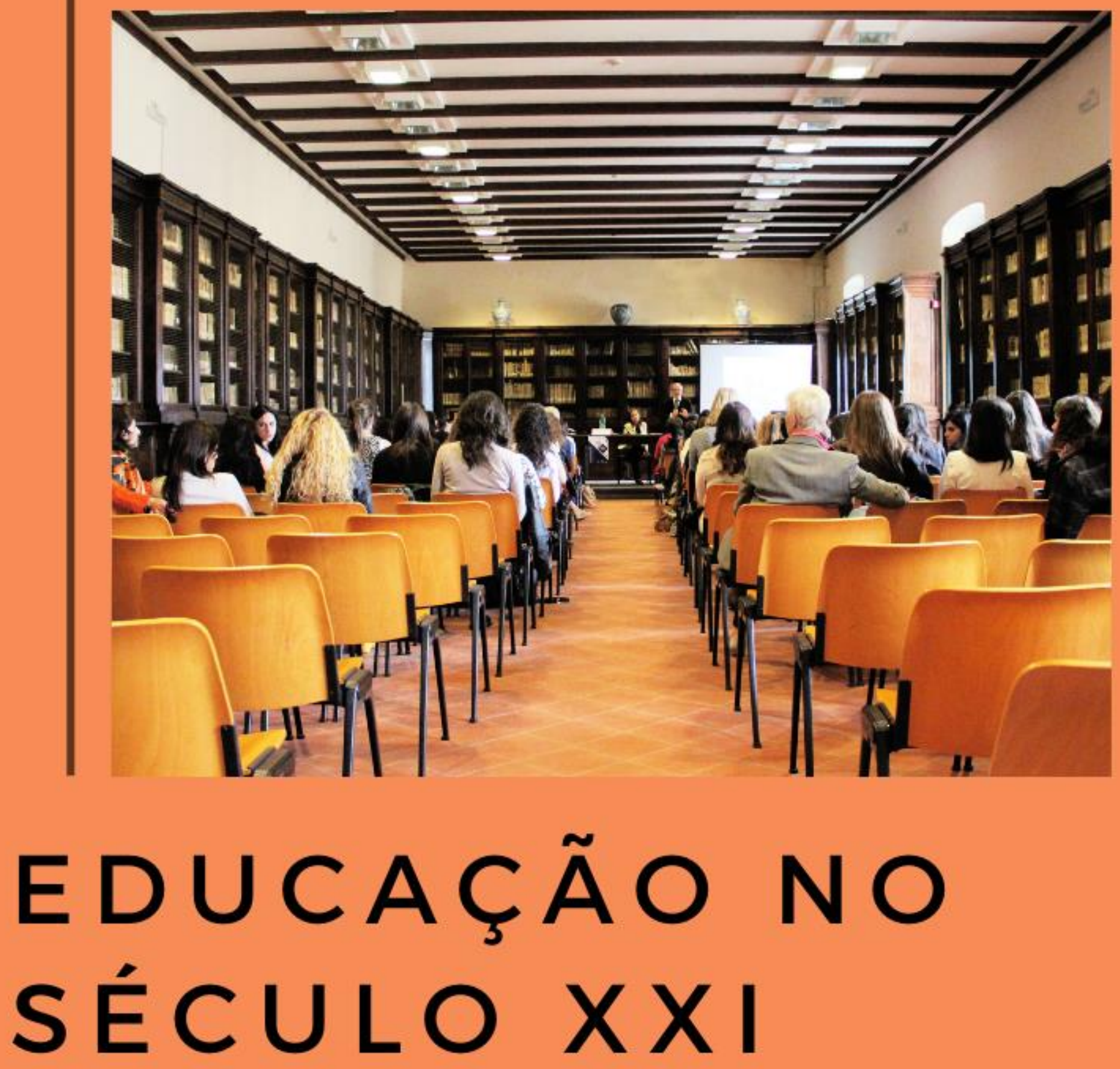

Prática Pedagógica

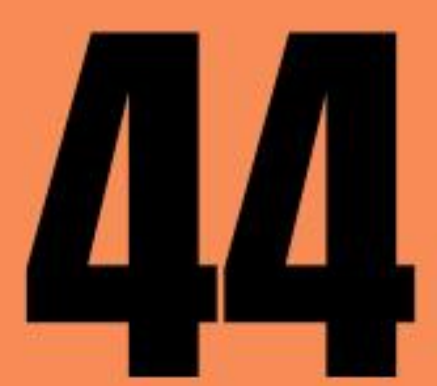

VOLUME

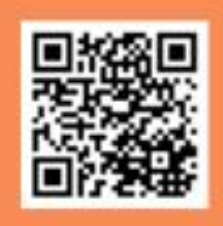


Editora Poisson

(organizadora)

\title{
Educação no Século XXI - Volume 44 \\ Prática Pedagógica
}

\author{
1a Edição
}

Belo Horizonte

Poisson

2019 
Editor Chefe: Dr. Darly Fernando Andrade

\section{Conselho Editorial}

Dr. Antônio Artur de Souza - Universidade Federal de Minas Gerais

Ms. Davilson Eduardo Andrade

Dra. Elizângela de Jesus Oliveira - Universidade Federal do Amazonas

Msc. Fabiane dos Santos

Dr. José Eduardo Ferreira Lopes - Universidade Federal de Uberlândia

Dr. Otaviano Francisco Neves - Pontifícia Universidade Católica de Minas Gerais

Dr. Luiz Cláudio de Lima - Universidade FUMEC

Dr. Nelson Ferreira Filho - Faculdades Kennedy

Ms. Valdiney Alves de Oliveira - Universidade Federal de Uberlândia

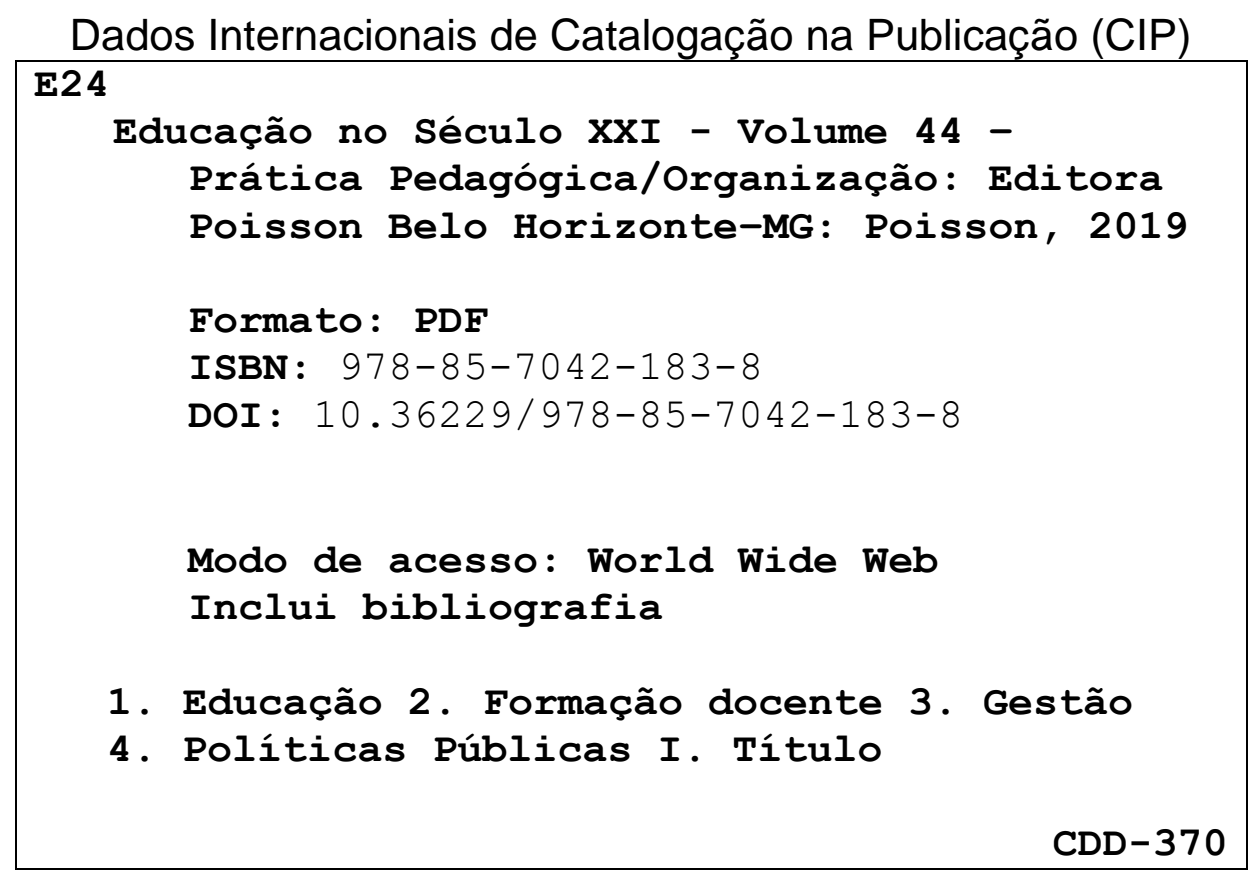

O conteúdo dos artigos e seus dados em sua forma, correção e confiabilidade são de responsabilidade exclusiva dos seus respectivos autores

www.poisson.com.br

contato@poisson.com.br 


\section{SUMÁRIO}

Capítulo 1: Representações sociais do campo de atuação do pedagogo: Reflexões sobre a técnica de associação livre de palavras. 08

Thamyris Mariana Camarote Mandú

DOI: 10.36229/978-85-7042-183-8.CAP.01

Capítulo 2: Cidadania e sustentabilidade: 0 papel da escola no século XXI para a formação de um "currículo transformador". 17

Gisely Capitulino da Fonseca

DOI: 10.36229/978-85-7042-183-8.CAP.02

Capítulo 3: Combatendo a indisciplina: Estratégias utilizadas pelo professor que podem contribuir para um ambiente de cooperação 21

Adriana Ferreira de Souza

DOI: 10.36229/978-85-7042-183-8.CAP.03

Capítulo 4: Os organismos multilaterais e a educação profissional e tecnológica: Um direito mercantilizado? 27

Jeane dos Santos Silva Viana

DOI: 10.36229/978-85-7042-183-8.CAP.04

Capítulo 5: 0 ensino de matemática do século XX no espaço Francês - Em busca de sua própria identidade

Luiz Fernandes da Costa

DOI: 10.36229/978-85-7042-183-8.CAP.05

Capítulo 6: A leitura do ambiente como ponto de partida para a educação ambiental integrada ao ensino de Matemática. 41

Daniana de Costa, Edilson Pontarolo

DOI: $10.36229 / 978-85-7042-183-8 . C A P .06$

Capítulo 7: Os resultados da avaliação diagnóstica em língua portuguesa e matemática para os alunos das primeiras séries do ensino médio da rede pública Estadual do Ceará: Um instrumento de gestão que orienta a formação e o planejamento docente. 48

Luciano Nery Ferreira Filho, Gezenira Rodrigues da Silva, Ana Paula Pequeno Matos, José Alves Ferreira Neto 


\section{SUMÁRIO}

Capítulo 8: A ação do reforço escolar por meio da ludicidade: Abordagem metodológica no ambiente do subprojeto matemática PIBID 57

Rodiney Marcelo Braga dos Santos, Maria de Fátima Pereira da Silva, José Jorge de Souza Silva, Fabrícia dos Santos Pereira, Felipe Erick Moura da Silva, Sabrina Karina da Silva Sousa

DOI: $10.36229 / 978-85-7042-183-8 . C A P .08$

Capítulo 9: 0 pedagogo e a formação do parfor: A práxis no ensino de história no interior da Bahia. 66

Keite Maria Santos do Nascimento Lima

DOI: $10.36229 / 978-85-7042-183-8 . C A P .09$

Capítulo 10: Aula de campo como recurso metodológico para o ensino de geografia física. 73

Patrícia Araújo de Sousa, Janiele Pereira da Silva Santos, Tamires dos Santos Cirilo Diniz, Alane de Souza Silva

DOI: $10.36229 / 978-85-7042-183-8 . C A P .10$

Capítulo 11: Uso de dispositivos móveis e aplicativos (APPS) no ensino da química: Revisão sistemática da literatura. 80

Fernanda Marcondes de Paiva

DOI: $10.36229 / 978-85-7042-183-8 . C A P .11$

Capítulo 12: Uma avaliação do modelo sala de aula invertida no ensino superior ..... 91 Adriana Doroteu Dantas, Luiz Sérgio Oliveira Barbosa, Isomar Lima da Silva, Thaís Helena Chaves de Castro, Nara Vieira da Silva, António Ribeiro da Costa Neto

DOI: $10.36229 / 978-85-7042-183-8 . C A P .12$

Capítulo 13: Filme como recurso didático no ensino de História 100 Mário Cézar Alves Ferreira, Eliane dos Santos Malheiros

DOI: $10.36229 / 978-85-7042-183-8 . C A P .13$

Capítulo 14: Reflexões do filme Escritores da liberdade a partir de uma prática pegagógica. 107

Eliane Picão da Silva Costa, Yasmin Coelho Figueiredo, Lucila Akiko Nagashima

DOI: $10.36229 / 978-85-7042-183-8 . C A P .14$ 


\section{SUMÁRIO}

Capítulo 15: Do ensino tradicional à abordagem humanista: Uma análise do filme sociedade dos poetas mortos..

Demóstenes Dantas Vieira, Efraim de Alcântara Matos, Pedro Felipe de Lima Henrique, Josenildo Pinheiro da Silva

DOI: $10.36229 / 978-85-7042-183-8 . C A P .15$

Capítulo 16: Direito e comunicação: Análise da relação entre língua portuguesa e comunicação não-verbal e a atuação profissional do bacharel em direito sob a perspectiva dos alunos de uma ies particular de Fortaleza (CE)

Raquel Figueiredo Barretto, Afonso de Deus Nunes Neto

DOI: $10.36229 / 978-85-7042-183-8 . C A P .16$

Capítulo 17: Gêneros e tipologias textuais na escola: Alternativas didáticas com o diário de leituras. 128

Geam Karlo Gomes, Josimere Maria da Silva, Josefa Maria dos Santos

DOI: $10.36229 / 978-85-7042-183-8 . C A P .17$

Capítulo 18: Estratégias Juri simulado e dramatização: Análise de suas contribuições numa proposta de superação da educação bancária. 137

Marinalva da Silva Ferreira, Marli Teresinha Quartieri, Miriam Ines Marchi

DoI: 10.36229/978-85-7042-183-8.CAP.18

Capítulo 19: Ficha catalográfica dinâmica como recurso educacional para cursos de biblioteconomia.

Graciane Silva Bruzinga Borges, Letícia dos Santos Miranda, Mariana Freitas Canielo de Carvalho, Celsiane Aline Vieira Araújo, Benildes Coura Moreira dos Santos Maculan

DOI: 10.36229/978-85-7042-183-8.CAP.19

Capítulo 20: Acessibilidade digital: Um estudo acerca da acessibilidade, usabilidade e comunicabilidade em portais institucionais federais 150

Mariano Castro Neto, Leonardo Rodrigues de Almeida

DOI: 10.36229/978-85-7042-183-8.CAP.20

Capítulo 21: Reflexões sobre a formação de professores de língua portuguesa em contexto escolar: Um estudo comparativo entre teoria e prática. 158

Paulo Ricardo Ferreira Pereira, Luciene Maria Patriota

DOI: 10.36229/978-85-7042-183-8.CAP.21 


\section{SUMÁRIO}

Capítulo 22: Levantamento florístico da Praia de Intermares - Cabedelo (PB-NE) ... 165 Rita Braga Soares da Silva, Maria Clara Gomes da Silva, Priscila Santos Fidelis da Silva, Hermes Machado Filho

DOI: $10.36229 / 978-85-7042-183-8 . C A P .22$

Capítulo 23: De mentes atadas se condiciona o saber: Eurocentrismo e colonialidade no ensino de história 172

Cauê Almeida Galvão

DOI: $10.36229 / 978-85-7042-183-8 . C A P .23$

Autores: 


\section{Capítulo 1}

Representações sociais do campo de atuação do pedagogo: Reflexões sobre a técnica de associação livre de palavras

\section{Thamyris Mariana Camarote Mandú}

Resumo: 0 presente capítulo vista discutir o uso da técnica de associação livre de palavras como importante recurso nas pesquisas em educação em que se utiliza a Teoria das Representações Sociais (TRS), tomando como suporte teórico-metodológico a abordagem estrutural da TRS. A partir do recorte de nossa pesquisa de mestrado, buscou-se discutir as representações sociais do campo de atuação do pedagogo tratando mais especificamente de seu conteúdo e estrutura. A pesquisa foi realizada no curso de Pedagogia oferecido no Centro de Educação da Universidade Federal de Pernambuco, da qual participaram 103 estudantes concluintes (8o e 9o períodos), matriculados nos três turnos oferecidos (manhã, tarde e noite). Os dados foram coletados a partir do teste de associação livre de palavras, que tem por objetivo fazer vir à tona os elementos constitutivos de uma representação mediante um estímulo indutor. Foi utilizado como ferramenta de análise o software EVOC. Na análise das evocações realizadas pelos sujeitos, contabilizamos um quantitativo total de 511 palavras, sendo 139 destas diferentes entre si. Após o tratamento dos dados, foi construído o quadro de quatro casas referente à expressão "Campo de atuação do pedagogo", que nos possibilitou apreender o conteúdo geral da representação social dos estudantes. 0 quadro indica que os elementos que possivelmente constituem o núcleo central da representação são escola e professor. Os resultados evidenciam uma representação do campo de atuação do pedagogo pautada em duas perspectivas: ao mesmo tempo em que o campo de atuação do pedagogo é concebido pelos estudantes como voltado para a escola e para a docência, ele também é considerado amplo, com possibilidade de atuação em diversos ambientes. A análise da organização interna dos elementos constituintes da representação nos permitiu entender tais contradições. Assim, destacamos a utilização do método de associação livre de palavras como importante instrumento na pesquisa ora apresentada.

Palavras-chave: Atuação do Pedagogo, Curso de Pedagogia, Representações Sociais, Estudantes. 


\section{INTRODUÇÃO}

0 presente capítulo visa discutir o uso da técnica de associação livre de palavras como importante recurso nas pesquisas em educação em que se utiliza a Teoria das Representações Sociais (TRS), tomando como suporte teórico-metodológico a abordagem estrutural da TRS. A partir do recorte de uma pesquisa mais ampla, buscou-se discutir, nesse trabalho, também apresentado em congresso científico, as representações sociais do campo de atuação do pedagogo tratando mais especificamente de seu conteúdo e estrutura.

De acordo com a trajetória histórica da formação do pedagogo, os espaços de atuação profissional do pedagogo passaram por mudanças decorrentes das configurações sociais, econômicas e políticas de cada época, bem como das grandes e rápidas mudanças ocorridas nos modelos de trabalho e nos padrões de relações sociais (BRZEZINSKI, 2011)

O curso de Pedagogia, lócus de formação desse profissional, foi passando por inúmeras modificações e adquirindo novas características quanto ao seu funcionamento, perfil, currículo e finalidade, seguindo decretos, leis e necessidades profissionais. Tais mudanças repercutiram diretamente no perfil do pedagogo, no seu campo de atuação profissional e nas funções por ele desempenhadas. A esse respeito, Peternella e Galuch (2012, p.1) consideram que "este espaço de atuação mostrou-se oscilante: ora a ênfase voltou-se às funções de técnico em educação, professor, ou seja, especialista; ora buscou-se a formação do docente, gestor, pesquisador, ou seja, generalista".

Atualmente, o curso de Pedagogia vem seguindo as especificações instituídas pelas Diretrizes Curriculares Nacionais - DCNs (BRASIL, 2006), passando a compreender diversas formações e campos de atuação. Segundo o art. $2^{\circ}$ das Diretrizes Curriculares Nacionais para o curso de Pedagogia, a área de atuação do pedagogo consistirá no

exercício da docência na Educação Infantil e nos anos iniciais do Ensino Fundamental, na modalidade Normal, e em cursos de Educação Profissional na área de serviços e apoio escolar, bem como em outras áreas nas quais sejam previstos conhecimentos pedagógicos (BRASIL, 2006, p. 1).

Depreende-se, portanto, que o curso de Pedagogia passa a ter como base de sua formação a docência e, ao mesmo tempo, ampliam-se as possibilidades de atuação profissional do pedagogo. Nesse sentido, reconhecemos que o conceito de docência instituído pelas DCNs compreende uma prática além do ensino na sala de aula, incluindo as funções de gestão, planejamento, coordenação, formulação e avaliação de políticas públicas na área de educação, produção e difusão do conhecimento científico e tecnológico, além de atividades de cunho educativo em espaços escolares e não-escolares (BRASIL, 2006).

Este estudo utilizou a Teoria das Representações Sociais (TRS) como suporte para essa compreensão, sobretudo à luz das teorias de Moscovici (1978), Jodelet (2005) e Abric (2000). A escolha dessa teoria se deu pelo fato de que as Representações Sociais vêm atuando como um importante suporte para os estudos na área educacional, ajudando a compreender o homem como ser social que se constitui através de processos de interações sociais com outros sujeitos. 0 estudo das representações sociais investiga como se formam e como funcionam os sistemas de referência que utilizamos para classificar pessoas e grupos, e para interpretar os acontecimentos da realidade cotidiana, se constituindo numa forma de pensamento social (MOSCOVICI, 1978; JODELET, 2005)

Conhecer os elementos constituintes da representação social e compreender como se configura sua organização interna apresenta-se como um procedimento de suma importância na apreensão das representações sociais construídas por determinados grupos acerca de objetos sociais. Nesse sentido, lançamos mão do uso da técnica de associação livre de palavras como um instrumento importante na apreensão dos elementos que constituem a representação social do campo de atuação do pedagogo pelos estudantes de Pedagogia, bem como na identificação da organização interna dessa representação, de onde emergiram os prováveis candidatos a núcleo central e sistema periférico da representação.

O teste de associação livre é uma técnica de coleta de dados que tem por objetivo fazer vir a tona os elementos constitutivos de uma representação; mediante um estímulo indutor, os sujeitos são solicitados a expressar palavras ou expressões que lhes tenham vindo instantaneamente à memória (SÁ, 1996; ABRIC, 2000). Abric (2000) ressalta que o método possui a vantagem de possuir um caráter mais espontâneo, permitindo uma facilidade de acesso aos elementos que compõem o universo semântico da representação maior do que, por exemplo, na entrevista. Segundo Sá (1996) a associação livre ainda permite que os elementos implícitos ou latentes da representação venham à tona. 


\subsection{CURSO DE PEDAGOGIA NO ÂMBITO DO CENTRO DE EDUCAÇÃO DA UFPE}

O curso de Pedagogia do Centro de Educação da UFPE também passou por reformulações com o intuito de se adequar às novas exigências da legislação e às novas demandas profissionais da sociedade, instituindo sua reforma em 2007, a fim de buscar uma formação mais sólida e completa para o profissional nela formado, e de adequar seu curso às normatizações das Diretrizes Curriculares Nacionais do Curso de Pedagogia (UFPE, 2007).

Constituindo-se em um curso de Licenciatura, tem o objetivo de formar para a atuação no Magistério em Educação Infantil e Séries Iniciais do Ensino Fundamental, cursos de Ensino Médio, na modalidade Normal e em outras áreas nas quais sejam previstos conhecimentos pedagógicos, funcionando nos três turnos, matutino, vespertino e noturno e possuindo uma carga horário total de 3.210 horas/aula e duração mínima de 5 anos (UFPE, 2007).

o Centro de Educação visa consolidar uma proposta de Curso de Pedagogia que assume a docência como base para a formação e a identidade profissional do pedagogo, na perspectiva da democratização da sociedade, do conhecimento e da educação, da valorização da educação e da escola pública (visando construir um ensino público de qualidade), buscando formar os profissionais da educação para a educação básica e para atuarem em vários outros campos profissionais formais e não formais em que sejam necessários conhecimentos pedagógicos, articulando ensino, pesquisa e extensão (UFPE, 2007).

\section{A TEORIA DAS REPRESENTAÇÕES SOCIAIS}

Moscovici (1978) concebe as representações sociais como teorias do senso comum, produzidas e partilhadas socialmente que orientam as práticas e justificam as condutas de grupos sociais, assim como a compreensão de mundo dos sujeitos a partir da criação e difusão de conceitos, explicações e afirmações acerca de determinado objeto social.

Nesse sentido, as representações sociais servem como guias da ação, uma vez que modelam e constituem os elementos do contexto no qual ocorrem, e desempenham, ainda, certas funções na manutenção da identidade social e do equilíbrio sociocognitivo, já que o sujeito, ao representar um objeto, se representa nesta relação (MOSCOVICI, 1978; JODELET, 2005).

Depreende-se, portanto, que a concepção de sujeito defendida pela teoria é a de um indivíduo ativo, inserido socialmente em determinado grupo social, mas também construtor dessa realidade social. 0 sujeito não é considerado um mero processador de informações externas, nem interage com o objeto social de forma neutra, ao contrário, ele interage de forma ativa no processo de apropriação da realidade objetiva e no processo de construção das representações sociais (SANTOS, 2005).

Para Jodelet (2001), o ato de representar envolve um processo ativo de construção e reconstrução mental do sujeito, de caráter referencial - as representações sempre são de alguém sobre algum objeto, de caráter imaginativo, construtivo, autônomo e social.

Por essa razão, ao representar, o sujeito, de forma ativa, realiza um processo de reconstrução do real permeada por uma dinâmica de comunicação que exerce um papel essencial no processo de construção e difusão de uma representação, pois permite uma troca de ideias entre os sujeitos, através de sua interação com seu grupo social, e o surgimento de novas representações ou a propagação de representações já construídas no grupo (JODELET, 2001). Outro aspecto a ser considerado no estudo das representações sociais é a orientação prática que a representação desempenha, permitindo ao indivíduo situar-se no mundo e compreendê-lo.

As representações contribuem, ainda, em processos como a assimilação de conhecimento, a construção de identidades pessoais e sociais, o comportamento intra e intergrupal, as práticas individuais e grupais, as ações de resistência e de mudança social. Assim, as representações sociais servem como guias da ação, uma vez que modelam e constituem os elementos do contexto no qual ocorrem, e desempenham, ainda, certas funções na manutenção da identidade social e do equilíbrio sociocognitivo, já que o sujeito, ao representar um objeto, se representa nesta relação (MOSCOVICI, 2007; JODELET, 2005). As Representações Sociais auxiliam na compreensão do pensamento e da prática social, permitindo entender como o pensamento social possibilita a construção de práticas comuns entre os sujeitos de determinado grupo. 


\section{A ABORDAGEM ESTRUTURAL DAS REPRESENTAÇÕES SOCIAIS}

Enquanto estruturas cognitivas, sociais e afetivas que se constituem em formas de conhecimento prático orientado para a compreensão do mundo e da comunicação, as representações sociais possuem uma estrutura organizacional e um conteúdo interno.

Abric (2000) propõe uma abordagem estrutural no estudo das representações sociais, que, segundo ele, são formadas por um núcleo central e um sistema periférico, sendo o núcleo central determinado pela natureza do objeto, pelo tipo de relações que o grupo mantém com o objeto e pelo sistema de valores e normas sociais que estão enraizados no grupo. Ele é o elemento estável e rígido da representação, assegurando sua continuidade em contextos móveis e evolutivos, resistente a mudanças. 0 núcleo central é que vai definir a representação, ou seja, se ele mudar, toda a representação mudará; e para que duas representações sejam diferentes, elas precisam ter núcleos centrais diferentes.

Ainda conforme Abric (2001), o núcleo central é o elemento estruturador da representação, possuindo um caráter gerador, organizador e estável. 0 núcleo central é determinado pela natureza do objeto, pelo tipo de relações que o grupo mantém com o este e pelo sistema de valores e normas sociais que estão enraizados no grupo. Ele é o elemento estável e rígido da representação, assegurando sua continuidade em contextos móveis e evolutivos, resistente a mudanças.

Esse elemento desempenha duas funções: i) função geradora: em que se cria o significado dos outros elementos que constituem a representação, dando-lhes um sentido, um valor; ii) função organizadora: unifica os elementos da representação e, assim, estabiliza-a. 0 núcleo central vai definir a representação, isto é, se ele mudar, toda representação mudará; e para que duas representações sejam diferentes, elas precisam ter núcleos centrais diferentes.

Os elementos periféricos também são componentes da representação, situando-se em torno do núcleo central. Sua principal função é a de proteger o núcleo, porém também exercem a função de ancoragem da representação e de regulação. Eles são mais móveis e flexíveis e mais sujeitos a mudanças. 0 sistema periférico está mais ligado às características individuais e ao contexto imediato; aqui o sistema cognitivo do sujeito tem vez, resultando em práticas diferenciadas.

Não obstante a grande importância do núcleo central para a representação social, o sistema periférico apesar de sua não centralidade na organização estrutural da representação, apresenta-se como elemento essencial na estrutura, definição e entendimento das representações sociais. Segundo Sá (1996), a estrutura das RS deve ser compreendida a partir do duplo sistema constituído pelo núcleo central e pelo sistema periférico, o que explica o caráter ao mesmo tempo estável e rígido, mutante e flexível das representações, que são simultaneamente consensuais e marcadas por diferenças interindividuais. Por isso as representações sociais não podem ser consideradas coros coletivos, sendo marcadas por fortes influências subjetivas.

Os elementos periféricos são os mais acessíveis e concretos das representações, assegurando o funcionamento quase instantâneo da representação, sendo menos estáveis que os elementos centrais; o sistema periférico desempenha um papel de modulação individual, sem colocar em xeque a significação central. Abric (2001) afirma que a periferia serve de zona de defesa entre a realidade que a desafia e o núcleo central, que não deve mudar facilmente. Os desacordos com a realidade são absorvidos pelos elementos periféricos, que asseguram a estabilidade da representação. Desse modo, o sistema periférico tem como função principal a proteção do núcleo central.

Além da função de defesa, os elementos periféricos desempenham mais duas funções essenciais: a função de concretização e a função de regulação. A função de concretização desempenhada pelo sistema periférico diz respeito à mediação que este realiza entre o núcleo central e a realidade concreta em que a representação é elaborada, sendo mais sensível ao contexto imediato; na função de regulação, o sistema periférico desempenha um papel de adaptação da representação aos contextos evolutivos, adaptando a representação aos novos contextos, integrando novas informações à representação, mas sem que haja mudança ou desestabilidade no núcleo central, por isso sua função de defesa, mantendo o núcleo central intacto e permitindo contradições (ABRIC, 1994; SÁ, 1996).

0 autor afirma que "a homogeneidade de uma população não é definida pelo consenso entre seus membros, mas sim pelo fato de que sua representação se organiza em torno do mesmo núcleo" (ABRIC, 2000, p.34), ou seja, um grupo pode ter uma representação de determinado objeto (determinada pelo núcleo central), mas pode ter práticas diferenciadas sobre o mesmo, o que é explicado pelo sistema periférico. 


\section{PERCURSO TEÓRICO-METODOLÓGICO DA PESQUISA}

A pesquisa foi realizada no curso de Pedagogia oferecido no Centro de Educação da Universidade Federal de Pernambuco, da qual participaram 103 estudantes concluintes ( $8^{\circ}$ e 9o períodos), matriculados nos três turnos oferecidos (manhã, tarde e noite).

Os dados aqui tratados constituem-se um recorte de pesquisa de mestrado, da etapa em que foi aplicado o teste de associação livre. A técnica da associação livre permite um acesso mais rápido e fácil aos elementos constituintes do universo semântico do objeto de investigação, além de conhecer sua estrutura e organização interna, particularmente com a identificação dos elementos centrais e periféricos da representação; mediante um estímulo indutor, os sujeitos são solicitados a expressar palavras ou expressões que lhes tenham vindo instantaneamente à memória. 0 método possui a vantagem de possuir um caráter mais espontâneo, permitindo uma facilidade de acesso aos elementos da representação (ABRIC, 2000).

Na presente investigação utilizamos como estímulo indutor a expressão "Campo de atuação do pedagogo", à qual o estudante tinha que atribuir as cinco primeiras palavras ou expressões que lhes viessem à lembrança ao lê-la. Em seguida os estudantes foram solicitados a escolher, dentre os elementos elencados, os dois que eles consideravam mais importantes a respeito da expressão e justificar o porquê.

$\mathrm{Na}$ análise de tais evocações, utilizamos como ferramenta o software EVOC desenvolvido pelo pesquisador Pierre Vergès (2000), que auxilia no cálculo estatístico de correlação entre dois critérios, a frequência de emissão das palavras evocadas no teste de associação livre, combinada com a ordem de importância atribuída pelo sujeito, formando um quadro de análise, denominado quadro de quatro casas, que permite uma melhor sistematização de tais dados e que possibilitará o levantamento dos possíveis elementos constitutivos do núcleo central e do sistema periférico.

Para Schuch et al (2008),

este programa organiza as palavras evocadas em quadrantes de acordo com a sua freqüência e ordem média de evocação. A freqüência é utilizada para avaliar o grau de compartilhamento das evocações no grupo pesquisado: quanto mais freqüente, mais compartilhada é a palavra. A ordem média é considerada como um índice de saliência: a evocação mais rápida significa que a palavra está mais acessível na memória de trabalho do sujeito, sendo facilmente ativada pelo estímulo indutor, o que sugere uma forte ligação com o mesmo (SCHUCH et al, 2008, p. 4891).

Os elementos dos quatro quadrantes que constituem o quadro de quatro casas produzido pelo EVOC (2000) podem ser interpretados de acordo com seus níveis de centralidade, uma vez que, no primeiro quadrante (superior esquerdo), estão situados os elementos que possivelmente integram o núcleo central da representação e que são os que possuem maior frequência de evocação e também os mais prontamente evocados; o segundo e terceiro quadrantes (superior direito e inferior esquerdo, respectivamente), por sua vez, representam os elementos constitutivos do sistema periférico (SÁ, 1996; VERGÈS, 2000), mas se encontram numa relação mais próxima ao núcleo central. 0 segundo quadrante comporta os elementos que possuem uma alta frequência, mas que foram evocados em últimas posições, e a terceira casa é constituída dos elementos que tiveram uma baixa frequência de evocação, mas que foram prontamente citados (MACHADO; ANICETO, 2010). No quarto quadrante encontram-se os elementos que constituem uma periferia mais distante do núcleo central.

\section{CONTEÚDO E ESTRUTURA DAS REPRESENTAÇÕES SOCIAIS DO CAMPO DE ATUAÇÃO DO PEDAGOGO}

$\mathrm{Na}$ análise das evocações realizadas pelos sujeitos, contabilizamos um quantitativo total de 511 palavras, sendo 139 destas diferentes entre si. Após o tratamento dos dados, foi construído o quadro de quatro casas referente à expressão "Campo de atuação do pedagogo", que nos possibilitou apreender o conteúdo geral da representação social dos estudantes e, mais especificamente, sua organização interna, identificando os elementos que possivelmente constituem o núcleo central da representação, bem como os elementos do sistema periférico, conforme podemos observar no quadro 1. 
Quadro 1 - Quadro de quatro casas gerado pelo EVOC a partir dos elementos associados à expressão indutora "campo de atuação do pedagogo"

\begin{tabular}{|c|c|c|c|c|c|}
\hline \multicolumn{3}{|c|}{$\mathrm{F}>=10 / \mathrm{OME}<2,5$} & \multicolumn{3}{|c|}{$\mathrm{F}>=10 / \mathrm{OME}>2,5$} \\
\hline \multirow{9}{*}{$\begin{array}{l}\text { Escola } \\
\text { Professor }\end{array}$} & $f$ & OME & & $f$ & OME \\
\hline & \multirow{8}{*}{$\begin{array}{l}65 \\
10\end{array}$} & \multirow{8}{*}{$\begin{array}{c}1,615 \\
2,00\end{array}$} & Coordenação & 16 & 3,313 \\
\hline & & & Empresa & 49 & 3,306 \\
\hline & & & Gestão & 13 & 3,615 \\
\hline & & & Hospitais & 35 & 3,914 \\
\hline & & & Movimentos-sociais & 10 & 2,900 \\
\hline & & & Ongs & 35 & 3,314 \\
\hline & & & Recursos-humanos & 12 & 3,500 \\
\hline & & & Sala-de-aula & 17 & 2,882 \\
\hline \multicolumn{3}{|c|}{$\mathrm{F}<10 / \mathrm{OME}<2,5$} & \multicolumn{3}{|c|}{$\mathrm{F}<10 / \mathrm{OME}>2,5$} \\
\hline & $f$ & OME & & $f$ & OME \\
\hline \multirow{7}{*}{$\begin{array}{l}\text { Diversificado } \\
\text { Educação }\end{array}$} & \multirow{7}{*}{$\begin{array}{l}5 \\
6\end{array}$} & \multirow[t]{7}{*}{$2,400,2,333$} & Amplo & 9 & 2,556 \\
\hline & & & Creche & 5 & 3,400 \\
\hline & & & Ensino & 7 & 2,857 \\
\hline & & & Formação & 7 & 4,000 \\
\hline & & & Mal-remunerado Pesquisa & 7 & 2,714 \\
\hline & & & Universidade & 8 & 2,875 \\
\hline & & & & 9 & 2,889 \\
\hline
\end{tabular}

Fonte: A autora

O quadro indica que os elementos que possivelmente constituem o núcleo central da representação social do campo de atuação do pedagogo pelos estudantes de Pedagogia são escola e professor, situando-se no quadrante superior esquerdo do quadro de quatro casas.

Levando em conta que o núcleo central constitui a base comum e consensual da representação, resultante da memória social do grupo e de seu sistema de normas, compreendemos que os elementos escola e professor encontram-se diretamente relacionados à função histórica do pedagogo e do curso de Pedagogia. 0 sistema central é essencialmente social e ligado às condições históricas, sociológicas e ideológicas, associadas aos valores e às normas do grupo social.

Esses elementos apontam para uma representação estritamente vinculada ao ambiente escolar, enquanto espaço de atuação profissional do pedagogo, e à função de professor enquanto principal atribuição a ser desempenhada nesse espaço. É importante observar que, historicamente, o pedagogo sempre teve a escola como espaço primordial de sua atuação. Além disso, as próprias DCNs estabelecem a docência como base de formação do pedagogo e a escola como campo prioritário de atuação desse profissional. Nesse sentido, a representação do campo de atuação do pedagogo é permeada por valores históricos e sociais atribuídas a esse objeto.

Dessa forma, é possível inferir que essa representação vai se firmando na formação inicial do pedagogo, levando em conta não só a base legislativa que regulamenta o curso, como também seu funcionamento e estrutura, pois prioriza em sua grade curricular disciplinas voltadas para a formação docente e os estágios curriculares (práticas pedagógicas) prioritariamente em ambientes escolares. Compreendemos, pois, que os elementos centrais dessa representação estão fundamentados em elementos históricos do objeto, mas também do contexto social e cultural em que atualmente está inserido.

O núcleo central das RS é definido pela natureza do objeto representado, pelas relações mantidas pelo grupo com o objeto, e regido pelo sistema de valores e normas sociais que fazem parte do ambiente em que o grupo está inserido. Possui a característica de manter a estabilidade da representação em contextos móveis e evolutivos, resistindo às mudanças, o que explicaria, em meio às novas aptidões exigidas do egresso do curso de Pedagogia e aos novos espaços de atuação atribuídas ao pedagogo, a permanência da representação desse profissional enquanto professor e da escola enquanto espaço de trabalho.

No quadrante superior direito, que representa os elementos periféricos mais ligados ao núcleo central, podemos perceber a presença dos termos coordenação, empresa, gestão, hospitais, movimentos-sociais, ONGs, recursos-humanos e sala-de-aula.

Os elementos empresa, hospitais, ONGs, movimentos-sociais e sala-de-aula podem ser categorizados como espaços de atuação, e permitem uma compreensão de quais espaços são considerados como possíveis para o exercício profissional do pedagogo. 0 sistema periférico protege o núcleo central, incorporando novos 
elementos à representação sem que a mesma seja modificada. Podemos, então, inferir que esses elementos foram integrados às representações, mas sem que houvesse ruptura do núcleo central.

Essas novas áreas de atuação do pedagogo começam a fazer parte da formação desse profissional e da realidade do curso de Pedagogia a partir da definição das DCNs, que passaram a reger o curso desde 2006. Embora reconheçam a profissão docente como eixo da formação do pedagogo e a escola como principal campo de atuação desse profissional, as Diretrizes Curriculares Nacionais relacionam outros espaços não escolares como locais de exercício profissional do pedagogo, onde este deverá desempenhar funções educativas e pedagógicas (BRASIL, 2006).

Os elementos coordenação, gestão e recursos-humanos indicam as funções que o pedagogo pode exercer nesses diversos ambientes. Como dispõem as diretrizes curriculares nacionais, as atividades elencadas como atribuições do pedagogo são: planejamento, execução, coordenação, acompanhamento e avaliação de tarefas, projetos e experiências educativas em ambientes escolares e não escolares. 0 termo sala-deaula, por sua vez, apresenta ligação mais direta com os elementos do núcleo central, uma vez que é o ambiente, dentro da escola, em que o professor exercerá sua profissão.

A representação dos estudantes, portanto, é de uma possibilidade de inserção do pedagogo em ambientes profissionais como empresa, hospitais, ONGs, sala-de-aula e movimentos-sociais, exercendo atividades de coordenação, gestão, recursos-humanos. Autores como Libâneo (2010) e Pimenta (2011) identificam a possibilidade de atuação do pedagogo em espaços escolares e não escolares, citando como principais ambientes extra-escolares as empresas, instituições hospitalares, meios de comunicação, espaços nãoformais de educação, entre outros. Considera-se, portanto, que, em todo ambiente em que houver práticas educativas ou pedagógicas, haverá a necessidade de contratação de um pedagogo.

Já no terceiro quadrante (inferior esquerdo), reconhecemos a presença dos termos diversificado e educação. 0 termo educação se constitui elemento dessa representação pelo fato de que a inserção do pedagogo em quaisquer que sejam os ambientes de trabalho está diretamente ligada à concepção de que a educação constitui-se como o elemento norteador de sua atividade profissional. Ou seja, o pedagogo atua em espaços em que sejam previstas práticas educativas, entendendo-se educação em seu sentido mais amplo. Por isso, esse elemento dialoga com o outro termo presente nessa periferia, diversificado, que corrobora a interpretação de que a educação pode acontecer em contextos e ambientes diversificados.

Os termos constituintes do quarto quadrante (inferior direito) são considerados elementos da periferia mais distante do núcleo central, a saber: amplo, creche, ensino, formação, mal-remunerado, pesquisa e universidade.

A periferia mais distante inclui os elementos mais diversificados da representação, mas que, ainda assim, apresentam ligação com os demais elementos e resguardam as características mais subjetivas da representação. Dessa maneira, podemos considerar que os estudantes de Pedagogia, ao representarem o campo de atuação do pedagogo, articulam elementos estáveis e enraizados socialmente que constituem o núcleo central com outros recém-incorporados à representação, mais ligados ao contexto imediato, sem que a representação fique comprometida. Constatamos, então, que, enquanto escola e professor constituem-se os prováveis elementos do núcleo central, a representação também incorporou outros elementos que vão além do entendimento proporcionado pelos do núcleo central, como amplo, diversificado, e pelos demais elementos que, na representação dos estudantes, definem o campo de atuação do pedagogo.

\section{CONSIDERAÇõES FINAIS}

No decorrer desta pesquisa, buscamos compreender as representações sociais do campo de atuação do pedagogo elaboradas pelos estudantes do curso de Pedagogia. Entendemos que na elaboração de tais representações entrelaçam-se diversos aspectos, de ordem social e subjetiva, dos quais podemos destacar os sentidos atribuídos ao curso, as concepções das atividades profissionais exercidas pelo pedagogo, a questão da valorização e da remuneração, as expectativas profissionais, entre outros.

Essas considerações nos fazem compreender que as representações sociais não são apenas opiniões, atitudes ou imagem de, mas também uma teoria sobre um objeto, integrando-o a uma rede de relações e significados de sua realidade social, num processo de interação com os demais membros desse meio, funcionando como um sistema de interpretação dessa realidade que orienta as práticas e justifica as condutas dos indivíduos. Dessa forma, foi possível apreender que os estudantes de Pedagogia articulam diversos aspectos na construção de sua representação social do campo de atuação do pedagogo. 
Os resultados evidenciam uma representação do campo de atuação do pedagogo pautada em duas perspectivas: ao mesmo tempo em que o campo de atuação do pedagogo é concebido pelos estudantes como voltado para a escola e para a docência, ele também é considerado amplo, com possibilidade de atuação em diversos ambientes.

A análise da organização interna dos elementos constituintes da representação nos permitiu entender tais concepções. Na elaboração dessas representações destacamos aspectos históricos e mais concretos que regem o curso quando nos deparamos com a concepção mais voltada para o pedagogo no ambiente escolar e exercendo principalmente atividades de ensino. Essas representações são mais relacionadas ao sistema central, que está ligado à memória social e à história do grupo, além de ser mais estável e rígida.

Ao mesmo tempo é possível identificar outro aspecto mobilizado na construção dessas representações, mais voltado para o contexto atual, integrando as mudanças e novas configurações desse campo, e, por isso, mais relacionado ao sistema periférico. Essa representação em que o estudante atribui ao campo de atuação do pedagogo um aspecto de amplitude e de possibilidade de exercício em diversos ambientes articula-se com perspectivas de ascensão profissional, de melhores condições de trabalho e de remuneração, e de maior valorização profissional.

Assim, destacamos a utilização do método de associação livre de palavras como importante instrumento na pesquisa ora apresentada, uma vez que sua utilização permitiu um aprofundamento na compreensão das representações sociais do campo de atuação do pedagogo, além de terem possibilitado a percepção das contradições que permeiam tais representações.

Por fim, destacamos que a formação e a especificidade profissional do pedagogo vêm se refazendo historicamente, sendo atualmente regulamentadas pelas Diretrizes Curriculares Nacionais, que instituem novas características para esse profissional, bem como abrem novas possibilidades de atuação e de atribuições para o mesmo. Nesse contexto, os cursos de Pedagogia sofreram mudanças quanto a seu funcionamento, estrutura e especificidade. Consideramos, portanto, que, diante dessa reconfiguração do curso de Pedagogia e das atribuições profissionais do pedagogo, torna-se importante a realização de pesquisas que tratem das novas configurações profissionais que vem se delineando a com base nessas novas regulamentações do curso.

\section{REFERÊNCIAS}

[1] Abric, J. C. "Les représentationssociales: aspects théoriques." In: Abric J-C. Pratiques sociales et représentations. Paris: PressesUniversitaires de France, 1994.

[2] Abric, J. C. A abordagem estrutural das Representações Sociais. In: Moreira, A.S.P.; Oliveira,D.C. Estudos interdisciplinares de Representação Social. 2.ed. Goiânia: AB, 2000. p. 27-37.

[3] Abric, J. C. O estudo experimental das representações sociais. In: Jodelet, D. As Representações Sociais. Rio de Janeiro: EdUERJ, 2001. p. 155-171.

[4] Brasil. Resolução Cne/CP № 1, de 15 de maio de 2006. Institui Diretrizes Curriculares Nacionais para o Curso de Graduação em Pedagogia, licenciatura. CNE, 2006.

[5] Brzezinski, I. Pedagogo: delineando identidade(s). Revista UFG, Ano XIII, no 10, Julho 2011.

[6] Jodelet, D. Representações sociais: um domínio em expansão. In: Jodelet, D. (Org.). As representações sociais. Rio de Janeiro: Eduerj, 2001. Trad. Lilian Ulup.

[7] Jodelet, D. Loucuras e representações sociais. Petrópolis: Vozes, 2005. Trad. Lucy Magalhães.

[8] Libâneo, J. C. Pedagogia e pedagogos, para quê? 12. ed. São Paulo: Cortez, 2010.

[9] Machado, L. B.; Aniceto, R. A. Núcleo central e periferia das representações sociais de Ciclos de Aprendizagem entre professores. Ensaio: Avaliação e Políticas Públicas em Educação, Fundação Cesgranrio, v. 18, n.67, p. 345-363, Rio de Janeiro, Abr./Jun. 2010.

[10] Moscovici, S. A representação Social da Psicanálise. Rio de Janeiro: Zahar Editores, 1978. Trad. Álvaro Cabral.

[11] Moscovici, S. Representações Sociais: investigações em psicologia social. 5. ed. Trad. Pedrinho A. Guareschi. Petrópolis: Vozes, 2007

[12] Peternella, A.; Galuch, M. T. B. A formação do pedagogo sob a orientação de documentos elaborados no início do século XXI: da necessidade de continuar o debate. In: XI Seminário de Pesquisa em Educação da Região Sul (Anped SUL), 2012, Caxias do Sul. Anais do IX Seminário de Pesquisa da Região Sul, 2012. Disponível em: 
<http://www.ucs.br/etc/conferencias/index.php/anpedsul/9anpedsul/paper/viewFile/1872/477>. Acesso em: $21 / 07 / 2014$.

[13] Pimenta, S. G. Pedagogia e pedagogos: caminhos e perspectivas. 3. ed. São Paulo: Cortez, 2011.

[14] Sá, C.P.Núcleo central das representações sociais. 2. ed. Petrópolis, RJ:Vozes, 1996.

[15] Santos, M. F. S. A teoria das representações sociais. In: Santos, M. F. S.; Almeida, L. M. Diálogos com a teoria das representações sociais. Recife: Ed Universitária da Ufpe/Ufal, 2005. p. 13-38.

[16] Schuch, D. S. et al. O uso de instrumentos teórico metodológicos da representação social na pesquisa em Educação Ambiental. In: Anais do VIII Congresso Internacional de Educação - Educere. Curitiba: Editora Champagnat, 2008. Disponível em: <http://www.pucpr.br/eventos/educere/educere2008/anais/pdf/678_425.pdf >. Acesso em: $06 / 05 / 2012$.

[17] Universidade Federal de Pernambuco - Ufpe. Projeto Pedagógico do curso de licenciatura em Pedagogia do Centro de Educação/Ufpe. Recife, 2007.

[18] Vergès, P. Ensemble de programm espermettant l'analyse dês evocations. Evoc2000. Manuel. Paris, 2000. Disponível em: <http://www.pucsp.br/pos/ped/rsee/evoc.htm>. Acesso em: 06/05/2012. 


\section{Capítulo 2}

\section{Cidadania e sustentabilidade: O papel da escola no século XXI para a formação de um "currículo transformador"}

\section{Gisely Capitulino da Fonseca}

Resumo: Este trabalho tem função primordial de pensar o papel do educador/professor como agente participante do processo de crescimento das forças produtivas e inovações tecnológicas (quer nas áreas das Ciências Biológicas, ou nas áreas das Ciências Humanas), bem como explorar a concepção de projetos políticos pedagógicos nas escolas que envolvessem o papel dos professores (de boa parte das disciplinas escolares) em sala de aula e que englobasse conteúdos ou assuntos (tais quais o próprio conceito de sustentabilidade e globalização) de forma interdisciplinar e de forma a garantir uma educação menos desvinculada do mundo e do tempo em que estes jovens e adolescentes vivem.

Palavras-chave: Prática Educativa; Sustentabilidade; Cidadania; Globalização. 


\section{INTRODUÇÃO}

O enfoque e a intenção primordial deste trabalho, que ainda está em fase inicial, tendo sido apresentado no IV Congresso Nacional de Pesquisa e Ensino em Ciências, é o de evidenciar o papel da escola no século XXI, como um meio para que se reflita o caráter cidadão e formador de uma educação voltada para a sustentabilidade em meio ao mundo globalizado. Com isso, a escola é uma das instituições presentes na sociedade que melhor poderia contribuir para um pensamento sustentável, consciente e transformador.

Por isso, os objetivos, antes de tudo, são de justamente demonstrar como a escola (bem como seus espaços hierarquizados, institucionalmente acrescentando) poderia auxiliar para o fomento dos nossos jovens e adolescentes com base na ideia de um mundo que encontra-se em sucessivas mudanças tanto tecnologicamente, quanto ainda, mudanças no contexto ambiental e da natureza com a exploração dos recursos naturais. Além de que, a própria ideia de sustentabilidade atrela-se ao conceito de não apenas educar para formar cidadãos conscientes acerca de como tornar a sua comunidade ou o mundo, um lugar melhor para se viver, mas ainda, de educar para o futuro e de conceber ainda, formar de repensar acerca do próprio fazer econômico, político e social, para compreender o caráter global do planeta e sua vinculação com a relação "produtividade X sustentabilidade":

A visão superficial (das aparências) nos mostra o crescimento espantoso das forças produtivas [...] que chegaram a níveis inéditos. E as inovações tecnológicas - o famoso progresso técnico - seguem em ritmo e velocidade alucinantes, impulsionadas por dispêndios que chegam a quase um trilhão de dólares por ano em pesquisa e desenvolvimento. (RATTNER, 2008, P. 53)

Desta maneira, ainda, este trabalho tem função primordial de pensar também o papel do educador/professor como agente participante deste processo (quer nas áreas das Ciências Biológicas, ou nas áreas das Ciências Humanas), bem como explorar a concepção de projetos políticos pedagógicos nas escolas que envolvessem o papel dos professores (de boa parte das disciplinas escolares) em sala de aula e que englobasse conteúdos ou assuntos (tais quais o próprio conceito de sustentabilidade e globalização) de forma interdisciplinar e de forma a garantir uma educação menos desvinculada do mundo e do tempo em que estes jovens e adolescentes vivem.

\section{MATERIAIS E MÉTODOS}

Pretende-se efetuar assim, todo o levantamento bibliográfico necessário com a finalidade de analisar alguns aspectos e problemáticas apresentadas, sendo desta maneira, utilizados teóricos da área da Educação, bem como as próprias obras de Paulo Freire que constituem-se no âmbito educacional. Ademais, quanto aos objetivos e seguindo os parâmetros de elaboração de projetos de pesquisas, este trabalho tem caráter "exploratório, lidando com uma base mínima de dados" a fim de considerar análises que expliquem as problemáticas, levando a uma solução viável, possível, diante dos objetivos propostos (GIL, 2008, p. 41).

Além disso, quanto à abordagem do problema, possui um teor qualitativo, pois interpreta os problemas gerais atribuindo significado e análise aos mesmos, já que estes não podem ser compreendidos ou refletidos apenas de forma quantitativa, de acordo com Prodanov e Freitas (2013). Quanto ao método de abordagem do trabalho, segue-se o processo de método dialético de abordagem das problemáticas e considerações ora apresentadas, pois é um método de interpretação dinâmica e totalizante da realidade, pois considera que os fatos não podem ser revelados fora de um contexto social, político, econômico, etc (PRODANOV; FREITAS, 2013, p. 34).

Desta maneira, como forma de acesso às fontes e referências será utilizado uma vasta gama de materiais online que advieram de pesquisas em sítios de busca para que se pudesse realizar as reflexões, análises e demonstrações aqui presentes. Dentre eles foi-se utilizado nos estágios iniciais, o acervo online da biblioteca de Paulo Freire para aquisição de materiais de sua autoria, bem como materiais de autores contemporâneos e ligados à área educativa. 


\section{DESENVOLVIMENTO}

Com isso, é preciso ressaltar que a linha teórico-metodológica para discussões sobre a temática aqui apresentada seguirá os pressupostos das visões de Paulo Freire e sua teoria da educação transformadora/emancipadora, onde apenas suas obras e suas teorias serão aqui repensadas de forma a aplicar suas ideias ao ensino da sustentabilidade no meio globalizado e de quais etapas e embasamentos seriam possíveis para que fossem implementadas bases gerais de discussões desta temática em sala de aula, contribuindo para uma educação que, além de cidadã, como já ressaltado, é conscientizadora. É esta ideia de "conscientização" que Freire também trabalha em seus estudos, ou seja, essa "consciência" que deve ser despertada no indivíduo, e aplicada a busca pela ação e a compreensão, tornando o pensamento de Freire bastante atualizado para a proposta em questão. Além deste autor, que é de suma importância para o desenvolvimento das bases gerais por um currículo transformador, ainda serão trabalhados teóricos como o historiador e filósofo francês, Jules Michelet e ainda, teóricos da área da educação, tais como Carlos Alberto Torres, Moacir Gadotti e Ângela Biz Antunes.

\section{RESULTADOS E DISCUSSÃO}

Sendo assim, como um dos resultados esperados, pretende-se lançar etapas de propostas procedimentais de conteúdos, questionamentos ou assuntos que se relacionem ao eixo da educação ambiental e da globalização, de forma a criar conteúdos interdisciplinares, especialmente de forma a interligar os eixos das Ciências Humanas e Biológicas, mas com o embasamento geral vinculado a aplicabilidade de práticas de ensino que possibilitasse a simplicidade na associação teóricometodológica destes eixos. Além disso, é preciso pensar e repensar os projetos políticos pedagógicos nas escolas brasileiras, pois uma problemática inicial que encontra-se no impedimento de um currículo transformador, mais vinculado ao mundo em que estes jovens vivem e de certa forma, mais popular e acessível, é justamente a característica fixa a que boa parte das escolas seguem seus planos políticos pedagógicos o que dificulta a real efetivação de algo que vá além do que "estudar para passar na prova".

Logo, a efetivação por uma educação popular e acessível, de acordo com a concepção freiriana, pois temáticas como sustentabilidade e educação ambiental não podem ou não deveriam ser assunto exclusivo de alguns, é que evidencia a possibilidade não-utópica de uma real implementação da temática de modo a vinculá-la ao caráter interdisciplinar que possibilita e facilita, para estes jovens em idade escolar, o processo de conhecimento e que viabiliza à chamada para uma conscientização crítica, que deve ser iniciada não apenas na fase adulta:

A sensação de pertencimento à Terra não se inicia na idade adulta e nem por um ato de razão. Desde a infância, sentimo-nos ligados com algo que é muito maior do que nós. Desde criança, nos sentimos profundamente ligados ao universo e nos colocamos diante dele num misto de espanto e de respeito. E, durante toda a vida, buscamos respostas ao que somos, de onde viemos, para onde vamos, enfim, buscamos respostas à questão do sentido da nossa existência. É uma busca incessante, que jamais termina. (TORRES; GADOTTI, 2018, p. 360)

\section{CONSIDERAÇõES FINAIS}

Portanto, a escola tradicional ou a chamada escola velha é algo que precisa ser considerada como fruto de longas e intermináveis reflexões, bem como a análise de maneiras que possam minimizar, pelo menos, a desatualização que boa parte das escolas trazem consigo no que concerne aos seus projetos políticos pedagógicos e a não representatividade do professor como autor que possibilite um currículo transformador. Contudo, como bem podemos também concluir, nestas fases iniciais, é de que há ainda educadores que também inviabilizam este "currículo transformador", capaz de fazer despertar nos jovens e adolescentes em idade escolar, meios de diálogo para soluções cotidianas e sustentáveis ao meio ambiente e que se relacionam ao mundo globalizado.

São estes ciclos e relações intermináveis que deterioram a prática de um fazer pedagógico mais dinâmico, inovador e atual, pois em pleno século XXI, temos ainda que refletir e ainda encontrar soluções para o fazer teórico-metodológico nas salas de aula, ou seja, este assunto está longe de esgotar-se. 
Por isso, a temática aqui apresentada neste trabalho não é algo que devêssemos pensar moderadamente, devido ao alto teor deste tipo de educação tradicional em grande parte das escolas brasileiras e que, como vemos, não traz resultados à nível, não de uma revolução (este não é ponto), mas à nível de mudanças na vida das pessoas, dos jovens, no meio em que convivem (comunidade ou demais outras instituições) e principalmente, no modo como podem encontrar soluções relacionadas a sustentabilidade para o mundo globalizado em que vivem, de como podem ser cidadãos conscientes também com os ecossistemas, e principalmente, como eles próprios podem pensar o futuro para as próximas gerações.

\section{REFERÊNCIAS}

[1] Antunes, Ângela Biz. Exercício da Cidadania desde a Infância. In: Reinventando Freire: A práxis do Instituto Paulo Freire. São Paulo, 2018.

[2] Gil, A. C. Como Elaborar Projetos de Pesquisa. 4. ed. São Paulo:Atlas, 2002.

[3] Prodanov, C.C.; Freitas E. C. Metodologia do Trabalho Científico: Métodos e Técnicas da Pesquisa e do Trabalho Acadêmico. 2. ed. Novo Hamburgo: Feevale, 2013.

[4] Rattner, Henrique. Economia Solidária: Por quê? In: Desafios da Economia Solidária. 1. ed. São Paulo: 2018.

[5] Torres, C. A.; Gadotti, M. Educar para a Cidadania Global e Planetária. In: Reinventando Freire: A práxis do Instituto Paulo Freire. São Paulo, 2018. 


\section{Capítulo 3}

Combatendo a indisciplina: Estratégias utilizadas pelo professor que podem contribuir para um ambiente de cooperação

\section{Adriana Ferreira de Souza}

Resumo: 0 presente trabalho é uma pesquisa-ação realizada numa escola pública estadual da cidade de Inhambupe sobre a indisciplina em sala de aula. Elaborado numa abordagem qualitativa, tem por objetivo apresentar como o professor está criando condições para garantir um ambiente propício para as relações interpessoais em sala de aula, por meio do detalhamento das ações de intervenção e estratégias aplicadas na escola, fundamentando-se na leitura de textos sobre a questão. Assim, propomos uma reflexão do docente sobre a sua práxis, criando estratégias que contribuem para um ambiente de cooperação, baseando-se no trabalho com a ética e valores humanos, possibilitando, assim, um melhor desempenho do aluno na escola.

Palavras-chave: indisciplina; ambiente; ações de intervenção e estratégias. 


\section{INTRODUÇÃO}

A gestão escolar, prevista na legislação, deve ser democrática, abrangendo as dimensões pedagógica, administrativa e financeira. Nessa perspectiva, o papel político-pedagógico do diretor implica na criação e consolidação de espaços onde haja a articulação entre todos os componentes da comunidade escolar com o objetivo de construir uma gestão democrática.

Assim, cabe ao gestor escolar o papel de coordenador, mediador e interventor nos processos pedagógicos desenvolvidos na unidade de ensino, constituindo um passo importante a criação de órgãos colegiados que possibilitem o processo de discussão com os representantes dos segmentos da comunidade escolar e a tomada de decisão em grupo acerca dos problemas ocorridos no ambiente escolar, apontando solução para os mesmos.

A indisciplina é um reflexo das desigualdades econômicas e sociais, da crise de valores e do conflito de gerações que afetam as relações interpessoais na sociedade e na escola. Alguns problemas no sistema de ensino relacionados às áreas pedagógica, administrativa e financeira também afetam o cotidiano escolar.

Assim, ao começar a trabalhar no Colégio Estadual Mário Costa Filho, na cidade de Inhambupe, em 2009, atuando como vice-diretora, observei que a indisciplina era um dos principais problemas do cotidiano escolar. Diante dessa situação, foi necessário que a escola elaborasse um projeto de intervenção que possibilitasse criar um clima propício para as boas relações em sala de aula e para a aprendizagem, utilizando o trabalho com a ética e valores humanos como estratégias para alcançar esse objetivo.

0 projeto de intervenção buscou promover um novo olhar em relação à indisciplina, com base em conceitos de desenvolvimento moral e ético aplicados ao processo educacional, incentivando os professores a refletir sobre a própria postura, considerando os princípios de um ambiente de cooperação na mudança de atitudes diante de situações de conflitos.

Com base nessa realidade, pretendo com esse trabalho apresentar a vivência de uma gestão democrática, onde foi possível a participação dos diferentes segmentos da unidade escolar na resolução de uma situação-problema, visando melhorar o funcionamento da escola.

0 projeto de intervenção teve por objetivo mudar a perspectiva em relação à indisciplina, pois a escola tem que se responsabilizar cotidianamente por garantir um ambiente de cooperação, em que o valor o humano, o respeito, a dignidade e a integridade marquem as relações interpessoais.

A problemática citada precisava amenizar ou solucionar os problemas da indisciplina dos alunos em sala de aula, possibilitando um ambiente propício ao estudo e uma melhor interação entre professor $\mathrm{x}$ aluno, baseando-se em estratégias que podem contribuir na resolução dos conflitos, destacando o trabalho com a ética e valores no processo ensino-aprendizagem.

\section{METODOLOGIA}

A pesquisa foi realizada com base na pesquisa-ação que, segundo Thiollent (1988), é um tipo de pesquisa social com base empírica que é concebida e realizada em estreita associação com uma ação ou com a resolução de problema. A pesquisa-ação teve início com a formulação do problema definido a partir da realidade da comunidade escolar.

Esse método contou com a participação da comunidade escolar na observação do problema para busca de uma solução. A partir das diversas ações propostas por um grupo (colegiado escolar) foi decidido as metas e meios necessários que contribuíram para melhor solução do problema investigado com o objetivo não apenas de solucioná-lo, mas obter uma mudança de postura diante de uma determinada situação.

Portanto, o presente trabalho foi realizado com base na pesquisa-ação concebida e realizada a partir da realidade do CEMCF em associação às diversas ações propostas pela comunidade escolar buscou a solução do problema investigado com o objetivo não apenas de solucioná-lo, mas para obter uma mudança de postura da escola diante de uma determinada realidade.

\section{RESULTADOS E DISCUSSÃO}

A palavra disciplina é de origem latina e significa discípulo. É um termo marcado pela polissemia. Segundo Estrela (1992, p.13), o termo disciplina designa um ramo de conhecimento ou matéria de estudo: punição, 
dor, instrumento de punição, direção moral, regra de conduta para colocar ordem numa coletividade, obediência a essa regra.

A disciplina na escola não é questão de boa conduta nem de formação. "Disciplina se aprende e é do interesse de todo mundo, porque facilita a relação da gente com as coisas." (MACEDO, 2005, p.24). Ser disciplinado significa saber cumprir regras, é saber se comportar como deve em diferentes situações.

A Escola deve se constituir em um espaço de normas, de convivência e, principalmente, um espaço para a realização do ato de educar. Ou seja, "um lugar de acolhimento, onde as diferenças são importantes para que o coletivo e ainda cada um, na sua individualidade, tenham uma educação significativa, de qualidade, criando condições para uma vida melhor e mais segura". (BRASIL, 2005, p.15).

Entre as maiores preocupações dos professores está indisciplina, um problema que interfere na aprendizagem dos alunos. Manter a indisciplina é, sem dúvida, uma arte que poucos professores dominam. O autoritarismo, os gritos e mandar os alunos para a diretoria não adianta mais. É necessário que os professores revejam os seus conceitos sobre esse tema.

Em 2009, ao fazer parte da nova equipe gestora do Colégio Estadual Dr. Mário Costa Filho, percebi que os professores não sabiam lidar com os conflitos existentes em sala de aula, prejudicando a convivência entre professores e alunos e interferindo na aprendizagem dos alunos.

A partir dessa situação, comecei a questionar que estratégias de intervenção os professores poderiam utilizar para contribuir para um ambiente de cooperação.

Segundo uma pesquisa realizada pela revista NOVA ESCOLA e dados extraídos do Ibope, em 2007, com 500 professores de todo o país, $69 \%$ dos professores apontavam a indisciplina e a falta de atenção entre os principais problemas em sala de aula. Sobre isso Vichessi diz que: "Mas o comportamento inadequado do aluno não pode ser visto como uma causa da dificuldade para ensinar. Ele é resultado da falta de adequação no processo de ensino." (VICHESSI, 2009, p.79)

Para que os professores possam refletir sobre esse assunto é preciso que os mesmos entendam "que a indisciplina é a transgressão de dois tipos de regra. 0 primeiro são as morais, construídas socialmente com base em princípios (...) étnicos. 0 segundo tipo, são as chamadas convencionais, definidas por um grupo com objetivos específicos." (VICHESSI, 2009, p.79)

0 projeto de intervenção surgiu dessa situação com o objetivo de mudar a perspectiva em relação à indisciplina, responsabilizando a escola em garantir um ambiente de cooperação, marcado por relações que valorizem o respeito, a dignidade e o outro.

Para isso, foi necessário organizar um projeto que, pelo menos, amenizasse essa situação e favorecesse as relações no ambiente escolar, proporcionando um melhor desempenho do corpo discente e docente, no que tange a sua motivação em dar aulas.

O aluno indisciplinado não é mais aquele que conversa e se movimenta na sala. É o que não tem limites, não respeita os sentimentos alheios e tem dificuldades de autonomia.

Alves (2005) afirma que a indisciplina é associada a três pontos: metodologia, conteúdo e relações interpessoais. Os professores que não enfrentam problemas de indisciplina são exatamente os que têm melhor desempenho nesses três aspectos.

O primeiro passo foi reunir o colegiado da escola para informá-los sobre a escolha do tema: Combatendo a indisciplina. A reunião ocorreu no dia 14 de julho de 2010 com a participação dos representantes dos segmentos que o compõe, onde foi discutido sugestões de ações que poderiam fazer parte desse projeto. Entre elas, o acordo de realizar mensalmente reuniões com o colegiado.

Antes de agir sobre o conflito, o professor deve procurar a causa do conflito, sendo essencial "saber como o ser humano se desenvolve moralmente." (VICHESSI, 2009, p.80). O que significa dizer que desde pequenas, as relações entre crianças e adultos devem ser baseadas "na cooperação e no entendimento do que é ou do que não é moralmente aceito e por quê. (VICHESSI, 2009, p.81). Outro fator que causa a indisciplina diz respeito à estrutura familiar. Antigamente, a família era cúmplice da escola, mas hoje tem deixado a desejar na educação dos filhos, contribuindo para muitos se tornarem rebeldes.

O segundo passo foi reunir grande parte do segmento professor para explicar a todos sobre o projeto, incluindo também sugestões de atividades (ações), contando com a colaboração de toda a comunidade escolar. Nessa reunião, foram distribuídas cartilhas com todas as informações necessárias sobre o projeto de intervenção, uma das ações que estava prevista no projeto. 
As ações previstas foram as seguintes:

1. Reunião da equipe escolar com os professores

2. Palestra

3. Fazer reuniões mensais com o colegiado escolar

4. Semana de integração

5. Distribuição de material escrito contendo reflexões (cartilhas)

6. Formação de grêmio estudantil

\section{Formação de comitês de evento e atividades esportivas}

8. Escolha de líderes de classe

9. Formação de grupo de teatro e de dança

A questão da indisciplina é apresentada aos professores de forma limitada e restrita desse comportamento. Muitos professores esperam que as crianças saibam se comportar perante aos colegas e aos professores, outros consideram que "essa formação moral seja feita $100 \%$ pela família." (VICHESSI, 2009 , p. 80). Isto não significa destituir a família na formação moral do aluno, mas considerar que a escola oferece um espaço propício para essa formação moral do aluno, a partir das relações interpessoais.

Os problemas da indisciplina em sala de aula interferem no andamento das aulas. "Os professores referem-se a este problema como um dos aspectos mais difíceis e perturbadores para quem leciona." (PICAD0, 2009, p.1).

Quanto à resolução de conflito, o professor precisa ter em mente que os mesmos não acabarão, sempre vão ocorrer. 0 mais importante é lidar com a causa do conflito e não atribuir culpa e impor punições. Não importa quem iniciou a discussão, mas analisar o que levou as pessoas a não saber solucionar o problema de forma justa e respeitosa.

Segundo Picado (2009), a psicologia cognitiva e comportamental pode auxiliar o professor em situações de conflito. Enquanto a ênfase em técnicas cognitivas dependerá da personalidade do aluno, do tipo de situação e das características da turma; as técnicas com ênfase na psicologia comportamental consideram o comportamento atual do aluno e nas interações com o meio imediato, buscando-se na observação e na importância da atuação do professor no comportamento do aluno.

A primeira ação do projeto aconteceu com a reunião com os professores para tratar da definição das outras ações que faziam parte do projeto. Em seguida, coloquei em prática com a ajuda dos outros componentes da equipe gestora e dos professores, a escolha dos líderes das turmas nos três turnos: matutino, vespertino e noturno. Depois da escolha dos líderes de turmas, eu e os avisei que os vice-líderes fariam uma reunião com eles. Na pauta, constavam esclarecimentos sobre o projeto de intervenção e orientações sobre as suas atribuições de líder e recomendações quanto a sua postura, incluindo a função dos líderes em ajudar os professores a manter a disciplina em sala de aula. Ficou acordado que as reuniões com líderes das turmas se realizariam mensalmente.

Algumas ações previstas durante a reunião com os professores foram colocadas em prática, como a reativação da rádio, do blog da escola e a formação dos comitês de evento e atividades esportivas. Foram organizados comissões de professores para cada um desses eventos e esses grupos formaram comissões de alunos para ajudá-los na sua realização.

Segundo (COULL, MARCHESI \& PALACIOS, 2004, p. 125), “a estratégia mais adequada é a do tipo preventiva. Ou seja, é preciso considerar o bem estar e a saúde dos alunos para um bom rendimento escolar."

Coull, Marchesi e Palacios (2004) afirmam ainda que uma proposta preventiva globalizadora não deveria centrar-se somente no âmbito escolar, mas teria que incidir também no contexto social. Portanto, as políticas sociais incentivam os fatores que geram bem estar, atuando positivamente no ambiente da escola.

Para realização dos grupos de teatro e de dança, procurei me informar se na escola existiam alunos que se identificavam com essas atividades. A funcionária de serviço de apoio do colégio da escola me ajudou nessa ação. Ela me informou o nome do estudante da 1a série, do turno matutino, que gostava de ensaiar passos de dança com outros alunos e de criar cenas teatrais também. Então, conversei com ele, expliquei 
mais detalhadamente sobre o projeto de intervenção, uma vez que os líderes de turma na qual estudava já haviam falado um pouco sobre isso.

Ficou combinado que ele convidaria alguns alunos para participar do grupo de dança e de teatro com a finalidade também de apresentar algo no dia da Semana de integração do CEMCF.

Dentre as ações propostas, apenas duas não foram realizadas: a formação do grêmio estudantil e o jornal da escola. No dia da reunião com os professores, dois professores ficaram responsáveis por essas duas ações. Essas ações não foram realizadas devido à falta de espaço onde fosse possível criar um grêmio e o tempo indisponível para a confecção do jornal.

Duas ações realizadas não estavam entre as ações planejadas. Uma foi a palestra proferida pelo Juiz da Comarca de Inhambupe. Essa palestra realizada na sala de eventos do CEMCF, às 14 horas, teve como objetivo informar aos alunos da importância dos estudos para a vida deles, a responsabilidade da conservação do patrimônio escolar e as consequências perante a lei caso isso não ocorresse.

Não foi possível a presença de todos os alunos do turno vespertino na palestra, pois o espaço não comportava muitas pessoas. Por isso, selecionamos alguns alunos com problemas de indisciplina de todas as turmas. Os alunos presentes se mostraram interessados no assunto discutido, uma vez que fizeram muitas perguntas sobre o assunto. No momento da apresentação, não se ouvia barulho na sala. Será que a postura do juiz influenciou nesse comportamento?

A segunda ação que não estava prevista foi a reunião de pais ou responsáveis dos alunos com a presença dos professores da escola. A reunião foi realizada nos três turnos (matutino, vespertino e noturno), com uma diferença, a reunião do noturno não contou com a presença dos pais ou responsáveis dos alunos, pois os mesmos já possuíam maior idade.

A formação moral do aluno sofre influência da família, dos meios de comunicação, do convívio com outras pessoas. A escola não é a única instituição social responsável pela educação moral dos alunos.

A atual Lei de Diretrizes e Bases (LDB), em seu título II, artigo $2^{\circ}$, afirma que:

"a educação, dever da família e do Estado, inspirada nos princípios de liberdade e nos idéias de solidariedade humana, tem por finalidade o pleno desenvolvimento do educando, seu preparo para o exercício da cidadania e sua qualificação para o trabalho." (BRASIL, 1996, p. 4)

Verifica-se que a escola como instituição específica destinada à educação tem participação no desenvolvimento da moral de seus alunos, embora não seja a única instituição que participa dessa formação. Sendo a família o primeiro espaço de convivência do aluno, mas não o único também, em que "o ser humano se relaciona com regras e valores da sociedade em que está inserido" (BRASIL, 1998, p.62)

A última ação colocada em prática foi a Semana de integração que ocorreu nos dias 20, 21 e 22 de outubro. A semana teve início com a palestra proferida pelo Juiz da comarca de Inhambupe. No dia 22 de outubro, houve a apresentação dos grupos de dança e de teatro da escola.

O último dia foi marcado pela competição de bolos em comemoração aos 38 anos da fundação do CEMCF e a homenagem ao Dia do Professor. A competição consistia na confecção de um bolo em obediência a alguns critérios. Cada sala teve professores responsáveis para ajudar na organização do evento. As salas foram avaliadas por jurados que analisaram os bolos de acordo com os critérios pré-estabelecidos. Os professores foram organizados por sala e por sorteio. Houve ganhadores nos turnos matutino (6M1 e 7M1) e vespertino (1V2). 0 turno noturno participou da confecção dos bolos, mas não competiram. Os jurados que fizeram o julgamento dos bolos foram os funcionários do turnos matutino, vespertino e noturno e a coordenadora do Colégio.

A escola por ser um espaço pautado nos princípios democráticos, coloca-se para ela a questão de como enfrentar o conflito entre os valores que o aluno traz e as normas e regras existentes no contexto escolar. Conflito que pode se traduzir em problema como, por exemplo, a indisciplina e a violência.

Então, cabe à escola definir regras para superar esse problema, afirmando valores que inclua o aluno numa situação de diálogo, onde o mesmo possa compreender a situação e possa sentir os princípios expressos em regras de convivência.

Ainda, segundo os Parâmetros Curriculares Nacionais, é necessário que o professor tenha conhecimento crítico da realidade em que se desenvolve seu trabalho, dos valores que fazem parte dessa realidade e que servirá para direcioná-lo na organização do trabalho. 
Para que o professor tenha condições de pensar em conteúdos de ensino que o auxilie na construção do plano de ação da área de conhecimento com a qual trabalha, é preciso que ele conheça criticamente a realidade do aluno, criando "estratégias que possibilitem o desenvolvimento das atividades desejáveis." (BRASIL, 1998, p. 77).

\section{CONCLUSÕES}

Antes de colocar em prática o projeto, muitas eram as reclamações dos professores quanto à indisciplina dos alunos e destes quanto à postura tomada pelo professor para conseguir dar as suas aulas sem muitas interferências.

A partir dessa realidade foi desenvolvido o projeto. 0 primeiro passo foi listar quais situações de indisciplina eram mais presentes no ambiente escolar e, principalmente, em sala de aula, com o objetivo de mudar a concepção de indisciplina que tinham os professores, em seguida, fazê-los refletir sobre a postura diante desses conflitos no cotidiano escolar, sem esquecer que regras são necessárias para a construção de um ambiente saudável.

Ao todo foram dez ações, entre elas, tivemos oito planejadas e realizadas, apesar das dificuldades encontradas na intervenção. Dentre as ações planejadas, somente duas não foram colocadas em prática: a formação do grêmio estudantil e o jornal da escola. Essas ações não foram realizadas devido à falta de espaço onde fosse possível criar um grêmio e o tempo indisponível para a confecção do jornal.

Em compensação, tivemos duas ações realizadas que não estavam entre as ações planejadas. Uma foi a palestra proferida pelo Juiz da Comarca de Inhambupe. A segunda ação que não estava prevista foi a reunião de pais ou responsáveis dos alunos com a presença dos professores da escola.

Com base nas ações e estratégias utilizadas pelo professor em sala de aula, durante a aplicação do projeto de intervenção, constatei que foi possível conseguir manter um ambiente harmonioso, capaz de despertar o interesse do aluno pelas aulas na escola.

Esclareço que os problemas no CEMCF não acabaram, apenas diminuíram os casos de indisciplina e as agressões físicas. E isso só foi possível, primeiramente, a partir da reflexão feita pelos professores sobre a sua postura em sala de aula e a utilização de novas estratégias diante de situações de conflitos para a resolução dos mesmos. A partir do empenho do professor no ensino da disciplina através do diálogo para a resolução de situações-problemas, o aluno pode torna-se disciplinado com o passar do tempo.

\section{REFERÊNCIAS}

[1] Alves, Cândido Maria Daltro. Disciplina. Rev. Nova Escola. Junho/Julho, 2005, ano XX, n. 183, p. 45-49.

[2] Bahia, Secretaria da Educação. Orientações Curriculares Estaduais para o Ensino Médio: Área de Linguagens, Códigos e suas Tecnologias/Secretaria da Educação - Salvador: A Secretaria, 2005.

[3] Brasil, Secretaria de Educação. Parâmetros Curriculares Nacionais: terceiro e quarto ciclos: apresentação dos temas transversais / Secretaria de Educação Fundamental. - Brasília: MEC/SEF, 1998. 436 p.

[4] _ _ _ LDB 9394/96 - Lei de Diretrizes e Bases da Educação Nacional, de 20 de dezembro de 1996.

[5] Coull, Marchesi, Palacios e Colaboradores. Desenvolvimento Psicológico e Educação. Porto Alegre: Artmed, 2004, 3v.

[6] Estrela, Maria Teresa. Relação Pedagógica, disciplina e indisciplina na sala de aula. Porto Editora, LDA. 1992.

[7] Macedo, Lino de. Disciplina. Rev. Nova Escola. Julho, 2005, ano XX, n.183, p. 24-26.

[8] Picado, Luís. A indisciplina em sala de aula: uma abordagem comportamental e cognitiva. 2009.

[9] Thiollent, Michel. Metodologia da pesquisa-ação. São Paulo: Cortez \& Autores Associados, 1988.

[10] Vichessi, Beatriz. Indisciplina. Rev. Nova Escola. Outubro, 2009, ano XXIV, n. 226, pp. 79-89. 


\section{Capítulo 4}

Os organismos multilaterais e a educação profissional e tecnológica: Um direito mercantilizado?1

\section{Jeane dos Santos Silva Viana}

Resumo: 0 sistema educacional brasileiro foi concebido como estratégia para viabilizar as novas configurações ou adaptações do projeto capitalista neoliberal. Essa mercantilização do processo educativo, sob influência dos Organismos Multilaterais vem produzindo alterações significativas em todos os níveis da educação. Nessa perspectiva, o texto objetiva-se a contribuir com discussão de alguns elementos acerca do impacto dos Organismos Internacionais na política educacional, mais especificamente na Educação Profissional e Tecnológica e tentará compreender como a mercantilização da educação fere a Constituição dos Direitos Humanos. Para isso, foi utilizada a pesquisa bibliográfica como instrumento metodológico. Este estudo possui a pretensão de colaborar com os debates que se contrapõem a mercantilização da educação em prol de uma educação pública que seja, de fato, democrática, laica e com qualidade social almejada em todos os níveis e modalidades de educação.

Palavras-chave: Organismos multilaterais; Educação profissional e tecnológica; Direitos humanos.

${ }^{1}$ A primeira versão deste artigo foi publicada nos anais da IV Jornada Ibero-Americana de Pesquisas em Políticas Educacionais e Experiências Interdisciplinares na Educação, 2019. 


\section{INTRODUÇÃO}

A entrada no século XXI foi marcada por modificações importantes no cenário político, social e econômico. 0 pensamento neoliberal passou a exercer forte e incisiva influência na constituição das políticas públicas e a educação brasileira, começou a lidar com reformas circundadas por acordos e recomendações dos organismos multilaterais (DE TOMMASI, WARDE e HADDAD, 2009). Instituições como o Banco Mundial (BM), o Fundo Monetário Internacional (FMI), a Organização das Nações Unidas para a Educação, a Ciência e a Cultura (UNESCO), a Organização Mundial do Comércio (OMC) e a Organização para a Cooperação e Desenvolvimento Econômico (OCDE) possuem grande poder influenciador no direcionamento de políticas educacionais.

A política educacional, segundo Nunes (2005), constitui um dos aparelhos necessários à formação de indivíduos em um modelo social determinado, é, assim, repleta de intenções. 0 sistema educacional brasileiro, a partir dos anos 1990, torna-se alvo estratégico para viabilizar as recomendações do projeto capitalista; os acordos e influências dos Organismos Multilaterais (OM), impostos pelas necessidades do capital, impuseram novas condições de efetivação do trabalho, conduzindo às mudanças significativas na modalidade de educação profissional e tecnológica (EPT) e, por sua vez, na formação de um novo perfil de trabalhador delineado à luz da lógica de competências.

Dessa maneira, o vigente estudo visa contribuir com alguns elementos acerca das influências e interferências dos OM nas políticas educacionais brasileiras, mais especificamente na EPT, apoiando-se na premissa da garantia do direito humano à educação e sua inserção no mundo do trabalho. Entendendo que o conteúdo desta discussão se faz presente e atuante na tessitura social mundial, em uma dinâmica de mundialização do capital, este texto possui a pretensão de colaborar com os debates que se contrapõem a mercantilização da educação em prol de uma educação pública que seja, de fato, democrática, laica e com qualidade social almejada em todos os níveis e modalidades de educação.

\section{INTERNACIONALIZAÇ̃̃O DAS POLÍTICAS EDUCACIONAIS}

Ao falar sobre internacionalização das políticas educacionais, importa destacar a concepção de Agenda Globalmente Estruturada para a Educação (AGEE) proposto por Dale (2004). A abordagem da AGEE é fundamentada por estudos atuais relacionados à política internacional, os quais apontam a economia capitalista mundial como a "mola propulsora" da globalização, a qual é estabelecida como:

Um conjunto de dispositivos político-econômicos para a organização da economia global, conduzido pela necessidade de manter o sistema capitalista, mais do que qualquer outro conjunto de valores. A adesão aos seus princípios é veiculada através da pressão econômica e da percepção do interesse nacional próprio. (DALE, 2004, p. 436).

Assim, de acordo AGEE no que tange os efeitos da globalização sobre a educação, a política nacional é demarcada, gerida e adaptada, em maior ou menor escala, conforme interesses internacionais. Segundo Dale (2004, p. 441), é "através da influência sobre o estado e sobre o modo de regulação, que a globalização tem os seus mais óbvios e importantes efeitos sobre os sistemas educativos nacionais".

Um dos marcos históricos para a internacionalização das políticas educacionais foi a Conferência de Jomtien/Tailândia - 1990. Este encontro proporcionou um desencadeamento de discussões a respeito da realidade educacional dos 155 países participantes da conferência mediante representação de seus governos. A UNESCO, o UNICEF - Fundo das Nações Unidas para a Infância, o PNUD - Programa das Nações Unidas para o Desenvolvimento e o BM foram os patrocinadores e financiadores deste evento.

A UNESCO representa o agente político que mais atua nas coordenadas da educação na América Latina. No setor educacional, este órgão ampara os países membros para que consigam atingir as metas do documento Educação para Todos ${ }^{2}$ no intuito de promover o acesso e a qualidade da educação em todos os níveis e modalidades. De acordo com Haddad (2008), foi com base no discurso da necessidade em melhorar a qualidade educacional, por meio de indicadores de avaliação, que foram apresentados os planos que reivindicam a mobilização e responsabilização de diferentes setores sociais para sua efetivação. Medeiros (2011, p. 85) reforça esta percepção apontando que

20 documento elaborado pela Comissão Mundial de Educação para Todos - Dakar (2000), uma década depois da Declaração Mundial de Educação para Todos, visa reiterar os compromissos assumidos quando da realização da conferência, estabelecendo metas para os compromissos então assumidos. 
Os ditames do capital, se apropriam dos discursos empreendidos ideologicamente para converter a educação num campo de disputa, onde individualidade e competitividade mascarada sob bases mercadológicas se configuram enquanto palavras de ordem do momento e se assumem enquanto "Educação para Todos" ou até mesmo "Todos pela educação", consolidando os pressupostos de uma sociedade plural. (Destaques no original).

A UNESCO avigora os ditames da política neoliberal, uma vez que atribui a sociedade civil uma responsabilidade pelas políticas sociais de educação que é do Estado, ou seja, a sociedade civil passa a ser vista como um espaço um espaço de ajuda mútua, de solidariedade e de fundamento da cidadania.

A atuação do BM na educação brasileira teve início durante a década de 1970, por meio da cooperação técnica e financeira, porém as relações foram fortalecidas a partir da década de 1990 quando o Brasil optou pelo apoio e sustento das estratégias e orientação dos OM em função da inserção brasileira nos moldes neoliberais (DE TOMMASI, 2009). A gerência do BM se dá através da aplicabilidade de programas de ajuste estrutural, os quais intervém diretamente na formulação, aplicação e controle de políticas sociais destes países. Gentili (2001, p. 29) ao se referir sobre o BM e a educação, expõe que estes organismos internacionais

[...] não se limitam a desempenhar as tarefas próprias de simples agências de crédito, mas exercem atualmente uma função político-estratégica fundamental nos processos de ajuste e reestruturação neoliberal que estão levados a cabo em nossos países [...].

Tais acordos, conforme apresentado por Oliveira (2000, p. 42), acabam "aprofundando os níveis preexistentes de desigualdade e exclusão social". O BM atua juntamente com o FMI no intuito de implementar e aprofundar políticas que beneficiem a reprodução do capital global (HADDAD, 2008). Os OM cumprem, portanto, com bastante eficiência o domínio dos processos produtivos e de acumulação do capital.

O setor de serviços representado pela OMC trata a educação em seus documentos como uma das esferas em que é possível a comercialização e ainda a destaca como uma das mais lucrativas. 0 objetivo da cooperação da OMC, juntamente com o FMI aos países periféricos, é a liberalização do comércio de bens e serviços e entre estes, a educação. A conexão predominante das influências dos OM são as condicionalidades entres estes órgãos, de maneira a manter em todas as ações a mesma lógica de dominação e conservação da hegemonia do capital.

0 movimento de internacionalização das políticas na educação expressa a dinamicidade da realidade econômica, política e cultural (LIBÂNEO, 2014). Os documentos gerados pelas agências internacionais, incisivamente influentes nas políticas educacionais do Brasil, possui o intuito de fazer com o sistema educacional se adeque ao capital, uma vez que este necessita de profissionais flexíveis e competentes tecnicamente (MALANCHEN, 2007).

\section{A CONCEPÇÃO DA EDUCAÇÃO PROFISSIONAL E TECNOLÓGICA: REORGANIZAÇÃO DO PROCESSO PRODUTIVO}

A Educação no Brasil historicamente serviu aos ditames do modelo econômico correspondente ao seu período e a Educação Profissional (EP), tal como hoje é conhecida, surge em um contexto de necessidade de qualificação das classes trabalhadoras diante de novas demandas e funções mercadológicas.

Segundo Moura (2010), são do início do século XIX, a partir de 1809, os primeiros vestígios da EP, com a criação do Colégio das Fábricas pelo Príncipe Regente, futuro D. João VI; surgiu como instrumento político de caráter assistencialista. Em 1909, foram criadas as Escolas de Aprendizes Artífices, pelo então Presidente da República, Nilo Peçanha; neste início do século XX, além do esforço público na disposição das 19 escolas nas unidades da Federação, houve uma modificação da perspectiva assistencial para a de preparação de operários para o exercício profissional. No período de 1930 a 1945, grandes transformações políticas, econômicas e educacionais marcam o Brasil, sendo proclamados diversos Decretos-Lei para normatizar a educação nacional, entre eles, o Decreto-Lei no 12 4.048/1942, o qual transformou as Escolas de Aprendizes Artífices em Escolas Industriais e Técnicas; criou o Serviço Nacional de Aprendizagem Industrial (SENAI), dando procedência ao que hoje se conhece como Sistema "S" (MOURA, 2010), formado pelo conjunto de organizações das entidades corporativas voltadas para o treinamento profissional, assistência social, consultoria, pesquisa e assistência técnica. 
Em 1959, por meio do Decreto no 47038 de 16 de fevereiro, as Escolas Industriais e Técnicas passaram a ser transformadas em autarquias denominadas de Escolas Técnicas Federais, ganhando autonomia didática e na gestão. No ano de 1971, a Lei no 5.692/71, Lei da Reforma de Ensino de 1ํ e 2o graus, "sob o discurso de uma escola única para ricos e pobres" (TAVARES, 2012, p. 6), transforma todo o currículo do antigo segundo grau em técnico-profissional, se apropriando de uma concepção de educação direcionada ao trabalho e estabelecendo um novo paradigma: formação de técnicos em caráter de urgência. Em 1978, promulga-se a Lei no 6.545 e três Escolas Técnicas Federais (Paraná, Minas Gerais e Rio de Janeiro) são transformadas em Centros Federais de Educação Tecnológica (CEFET's), recebendo a incumbência de formar engenheiros de operação e tecnólogos. Neste sentido, o vínculo com o mundo da produção é reafirmado e abre prerrogativa que se amplia posteriormente à outras instituições (BRASIL, 2010, p. 12).

A década de 1980 desponta com um novo panorama econômico e produtivo em escala mundial, a chamada globalização. Em 1986, a implantação do Programa de Expansão e Melhoria do Ensino Técnico (PROTEC) marca o início da relação do Estado brasileiro com os OM. O governo obteve empréstimo do Banco Mundial e, por meio do PROTEC, "visava implantar 200 escolas de nível técnico e agrotécnico, esses investimentos eram justificados pela necessidade de aumentar a assistência no ensino técnico" (TOMÉ, 2012, p. 8).

É a partir do final da década de 1980 e entrada na década de 1990 que se estabelece o "processo de readequação do Estado brasileiro aos desígnios do capitalismo internacional” (MINTO, 2010, p. 184). Paralelamente, o movimento da Educação Profissional e Tecnológica (EPT) lidou com diversas mudanças, passando a ser influenciada incisivamente pelos OM.

O processo de expansão da Rede Federal de Educação Profissional, Científica e Tecnológica foi promovido no decorrer do governo de Luiz Inácio Lula da Silva (2003-2010), ganhando continuidade no governo de Dilma Rousseff, mais intenso no primeiro mandato (2011-2014). Esse projeto de expansão

[...]se constituiu num marco histórico desta rede, inaugurada em 1909, na medida em que a ampliação do seu raio de atuação produziu mudanças tanto de ordem quantitativa, com o aumento significativo das unidades de ensino, quanto de natureza estrutural, fatores estruturantes da política implantada neste início de século XXI, com o objetivo de promover a formação de trabalhadores para atuar nos sistemas produtivos do país. (FRIGOTTO, 2016, p. 135)

Em 2018 completou-se dez anos da criação dos Institutos Federais de Educação, Ciência e Tecnologia (IFs) que possibilitou a instalação de várias unidades de EP por todos os estados do Brasil completando 659 instituições ${ }^{3}$.

A EPT compõe um dos eixos das ações do Plano de Desenvolvimento da Educação (PDE), o qual veio carregando uma série de medidas e adequações à política educacional do país e que, não diferente de vários projetos da política educacional brasileira, apresenta forte consonância com os objetivos propostos pelos organismos financeiros internacionais. A análise da trajetória centenária da educação profissional no Brasil mostra sua forte relação com o trabalho, que se fortalece com os arranjos do capitalismo mundial.

\section{A MERCANTILIZAÇÃo DA EDUCAÇÃO: VIOLAÇÃo DE UM DIREITO HUMANO PARA CONSERVAÇÃo DA HEGEMONIA}

De acordo com a Declaração Universal dos Direitos Humanos, os direitos humanos (DH) são inerentes a todos os seres humanos, independente de raça, sexo, nacionalidade, etnia, idioma, religião ou qualquer outra condição. Os DH incluem o direito à vida e à liberdade, à liberdade de opinião e de expressão, o direito ao trabalho e à educação, entre e muitos outros. Portanto, o acesso à educação, é um direito humano básico.

A proposta teórica dos DH de acesso à educação torna-se utópica, na medida em que desigualdades marcam a educação no Brasil e diferentes propostas educacionais intensificam estas disparidades. A configuração da universalização da educação básica a partir dos anos 90 foi consensual; este consenso constitui característica e estratégia da política neoliberal com a finalidade de manutenção do poder vigente, ou seja, para conservação da hegemonia.

3 Disponível em: http://portal.mec.gov.br/setec-programas-e-acoes/expansao-da-rede-federal. Acesso em 29 de jun. 2019. 
O conceito de hegemonia, segundo o autor italiano Gramsci, é fundamental para as reflexões que envolvem o desenvolvimento da sociedade capitalista burguesa e sua predominante ação. Para Gramsci (2002), a ascendência de um grupo social se traduz de duas maneiras; mediante o domínio e como direção intelectual e moral. Em outras palavras, um grupo sobressai na sociedade por meio da coerção (comando da força) ou do consenso, através da vigência de uma dominação ideológica. Na concepção gramsciana, o componente essencial da hegemonia é a sociedade civil e esta, por sua vez, representa o cenário legítimo do confronto de aspirações, desejos, objetivos, imagens, crenças e projetos que expressam a diversidade constituinte do social. A habilidade do grupo detentor do poder em agregar as manifestações dessa diversidade ao seu projeto global, a fim de obter o consenso para o controle social é a chamada hegemonia.

As relações hegemônicas são também relações pedagógicas, pois podem causar e desenvolver posições passivas e acríticas diante do predomínio ideológico, assim como podem também agir de maneira antagônica a anterior, expandindo a capacidade crítica, travando lutas políticas e ideológicas. Para que isso sobrevenha, as classes dominadas necessitam organizar sua própria ideologia para apresentarem condições de enfrentamento com a conjuntura dominante. Portanto, o exercício da hegemonia, para Gramsci (2002) se dá numa relação pedagógica que procura subordinar em termos morais e intelectuais grupos sociais por meio do convencimento e da educação.

Lima (2007, p. 48) afirma que "para os neoliberais o mercado é tudo e (...) os países devem subordinar suas políticas públicas aos imperativos da eficiência e da eficácia, ditadas pela racionalidade nova de um mercado globalizado". Nesta tessitura social, o neoliberalismo possui como estratégica a real manutenção da divisão de classes e dominação. A ofensiva neoliberal faz uso de singelas ações no âmbito educacional, de maneira a obter o apoio da sociedade civil e fazer com que esta não perceba as discrepâncias de propostas neoliberais para educação, o que viola os direitos humanos no que tange a uma educação igualitária para todos. Gentili (2001) reforça tal percepção quando fala que

a educação como direito social remete inevitavelmente a um tipo de ação associada a um conjunto de direitos políticos e econômicos sem os quais a categoria de cidadania fica reduzida a uma mera formulação retórica sem conteúdo algum. Partindo de uma perspectiva democrática, a educação é um direito apenas quando existe um conjunto de instituições públicas que garantam a concretização e a materialização de tal direito. Defender "direitos" esquecendo-se de defender e ampliar as condições materiais que os asseguram é pouco menos que um exercício de cinismo [...] (p. 247).

Dessa maneira, o novo contexto de produção desencadeou novas demandas e exigências para a educação, com destaque para a educação profissional e tecnológica. A apropriação que o capitalismo faz da educação, transformando-a em instrumento mercadológico vincula um direito humano universal aos interesses da classe dominante. Dallari (apud HADDAD, 2008, p. 12-13), afirma que

a educação escolar é um bem público e um direito humano. É fator essencial para a constituição e o desenvolvimento de uma sociedade e para a constituição de uma nação. No caso brasileiro, a educação, mesmo quando ofertada pela iniciativa privada, é considerada uma atividade de natureza pública, portanto, delegada pelo Estado, o que, em princípio, eliminaria a possibilidade da participação de estrangeiros nesse setor.

Esta defesa da educação como bem público já afronta os interesses da OMC, para o qual a educação é um dos serviços dispostos para fins de comercialização. Esta reestruturação do processo produtivo promove a "[...] citada privatização da função econômica atribuída à escola, uma das dimensões centrais que definem a própria desintegração do direito à educação [...]" (GENTILI, 1998, p. 89).

Os discursos neoliberais entram na defesa da educação como instrumento de emancipação humana, mas intimamente objetiva a formação de mão de obra para manutenção do mercado produtivo capitalista. Para Silva, Azzi e Boock (2008, p. 27), "a educação é encarada pelo Banco como a prestação (pública ou privada) de um serviço, e não como um direito de todos à transmissão e trocas de sabres, culturas e valores". A apropriação que o capitalismo faz da educação, transformando-a em instrumento mercadológico vincula um direito humano universal aos interesses da classe dominante. 


\section{CONSIDERAÇÕES FINAIS}

Considerando a discussão dos elementos envolvendo o modelo capitalista neoliberal, a educação profissional e tecnológica e o acesso à educação como direito humano, é possível delimitar alguns posicionamentos: No domínio das políticas recomendadas pelos organismos multilaterais, a afirmação e defesa da educação como direito universal é contraposta pela submissão à uma concepção economicista de educação, com interesses no retorno econômico por meio da formação de mão de obra; a análise da trajetória centenária da educação profissional no Brasil mostra sua forte relação com o trabalho, que se fortalece com os arranjos do capitalismo mundial. A origem e desenvolvimento das instituições de EPT, em função de determinações históricas, estiveram mais comprometidas com o capital do que com o trabalho, embora, em uma luta contra hegemônica, tentou-se e ainda tenta-se inverter esse sentido. A ofensiva neoliberal faz uso de várias ações no âmbito educacional para obter o apoio da sociedade civil e fazer com que esta não perceba as discrepâncias, incoerências e injustiças das propostas mercadológicas para educação.

Entende-se, contudo, que a anuência e efetivação das políticas educacionais no Brasil, mesmo sendo influenciada por orientações dos organismos multilaterais, depende da concepção de educação e de sociedade que a instituição se propõe a defender. Os projetos atuais de sociedade e de educação não são carregados apenas pelos determinantes de dominação, controle e imposição; há e sempre haverá espaço, tempo e força para a construção de resistências, lutas e oposições.

\section{REFERÊNCIAS}

[1] Brasil. Ministério da Educação. Concepções e diretrizes: Instituto Federal de Educação, Ciência e Tecnologia. Brasília: MEC/Setec, 2010.

[2] Dale, R. Globalização e educação: demonstrando a existência de uma "cultura educacional mundial comum" ou localizando uma "agenda globalmente estruturada para a educação"? Educ. Soc., Campinas, v. 25, n. 87, p. 423-460, mai/ago, 2004.

[3] De Tommasi, L.; Warde, M. J.; Haddad, S. (Org.) O Banco Mundial e as Políticas Educacionais. 6. ed. São Paulo: Cortez, 2009.

[4] Frigotto, G. [Coord.]. Os institutos Federais de Educação, Ciência e Tecnologia e sua Relação com o Ensino Médio Integrado e o Projeto Societário de Desenvolvimento (2003-2014). Relatório Técnico Científico Final do Projeto. Rio de Janeiro: CNPq e FAPERJ, abr, 2016.

[5] Gentili, P. Educar para o desemprego: a desintegração da promessa integradora. In: Frigotto, G. (Org.). Educação e crise do trabalho: perspectivas de final de século. 4. ed. Petrópolis: Vozes, 1998. p. 76-99.

[6] _ A falsificação do consenso: simulacro e imposição na reforma educacional do Neoliberalismo. 2. ed. Vozes: Petrópolis, 2001.

[7] Gramsci, A. Cadernos do cárcere. Trad. de Carlos Nelson Coutinho com a colaboração de Luiz Sergio Henriques e Marco Aurélio Nogueira. Rio de Janeiro: Civilização Brasileira, 2002.

[8] Haddad, S. (org). Banco Mundial, OMC e FMI: o impacto nas políticas educacionais. São Paulo: Cortez, 2008.

[9] Libâneo, J. C. Internacionalização das políticas educacionais: elementos para uma análise pedagógica de orientações curriculares para o ensino fundamental e de propostas para a escola pública. In: Silva, M. A. da; Cunha, C. da (Org.). Educação básica: políticas, avanços, pendências. Campinas: Autores Associados, 2014.

[10] Lima, M. J. C. de L. Neoliberalismo e Educação. Studia Diversa, CCAE-UFPB, v. 1, n. 1, out. 2007.

[11] Malanchen, J. As políticas de formação inicial a distância de professores no Brasil: democratização ou mistificação? 2007. 237f. Dissertação de mestrado - Universidade Federal de Santa Catarina. Florianópolis, SC, 2007.

[12] Medeiros, M. L. C. PDE: Um plano de desenvolvimento da educação na contramão do ensino público. In: III Encontro Norte/Nordeste - Trabalho, Educação e Formação Humana, Anais [...]. Alagoas, 2011. Disponível em: http://www.enntefh.com.br/anais/EIXO\%207.pdf. Acesso em 12 de jun. 2019.

[13] Minto, L. W. A administração escolar no contexto da Nova República e do Liberalismo. In: Andreotti, A.; LOMBARDI, J. C.; Minto, L. (Org.). História da Administração Escolar no Brasil: do diretor ao gestor. Campinas: Alínea, 2010. p. 173-200.

[14] Moura, D. H. A Relação entre a Educação Profissional e a Educação Básica na Conae 2010: Possibilidades e Limites para a Construção do Novo Plano Nacional de Educação. Educ. Soc., Campinas, v. 31, n. 112, p. 875-894, jul-set, 2010 .

[15] Nunes, A.I.B.L. Políticas e Reformas Educacionais: arenas de contradições e embates em torno da formação do professor. O público e o Privado, Fortaleza, v. 3, p. 113-136, 2015.

[16] Oliveira, D. A. Educação básica: gestão do trabalho e da pobreza. Petrópolis: Vozes, 2000.

[17] Silva, C. C. S.; Azzi, D.; Bock, R. Banco Mundial em foco: sua atuação na educação brasileira e na dos países que integram a Iniciativa Via Rápida na América Latina. In: HADDAD, S. (Org). Banco Mundial, OMC e FMI: o impacto nas políticas educacionais. São Paulo: Cortez, 2008. p. 15-86. 
[18] Tavares, M. G. Evolução da Rede Federal de Educação Profissional e Tecnológica: As etapas Históricas da Educação Profissional no Brasil. In: IX Seminário de Pesquisa em Educação da Região Sul - Anped Sul 2012. Anais [...] Caxias do Sul, $2012 . \quad$ Disponível http://www.ucs.br/etc/conferencias/index.php/anpedsul/9anpedsul/paper/viewFile/177/103. Acesso em 28 de mai. 2019.

[19] Tomé, A. C. de A. Trabalho e/ou Educação: História da Educação Profissional no Brasil. R. Educ. Ci. Tec., Canoas, v.1, n.2, 2012. 


\section{Capítulo 5}

\section{0 ensino de matemática do século $X X$ no espaço Francês - Em busca de sua própria identidade}

\section{Luiz Fernandes da Costa}

Resumo: Ao pesquisar-se o cotidiano escolar da França, país de renomada participação na história da Matemática e um dos berços de diversas ciências, tem-se por objetivo analisar o percurso da Matemática durante o século XX, seus conteúdos, discussões, avanços e retrocessos. Essa busca histórica servirá em momento posterior para comparar com as diferenças e similitudes que ocorreram no mesmo período com a Matemática em solo brasileiro. Para tal alcance utilizou-se a metodologia de revisão de bibliografia, conhecimento das principais reformas e leis que nortearam as mudanças na política educacional, e que por sua vez contribuíram para os resultados alcançados ao fim do século XX. A conclusão a que se chega é que a França acompanhou de perto o ensino de Matemática, intervindo sempre que necessário. Mesmo assim algumas das propostas feitas ao longo do século em foco não alcançaram de imediato os resultados esperados. Finalmente na década de 1980 a nação parece ter encontrado a solução para suas intensas buscas na construção de um padrão de educação nacional. Nesse período foi construído um currículo que contempla todos os níveis de ensino, ensejando a continuidade dos estudos. 0 trabalho prossegue buscando atender o binômio formação e progresso, pelo qual se procura manter a qualidade de ensino, da formação de professores e de fomento para o progresso nacional. Essa ideologia é fortalecida no fim dos anos de 1990 quando foi feito um balanço sobre as realizações educacionais da França durante o século e os resultados finais foram considerados satisfatórios. 


\section{DESENVOLVIMENTO}

Durante a Terceira República (1870 - 1940), ano de 1899, o parlamento francês buscou discutir as questões educacionais com a intenção de qualificar e aperfeiçoar a formação de seus cidadãos. Para essa busca formularam algumas teses. Dentre elas figuravam: - Que tipo de qualificação deve ser oferecido ao homem moderno? - De que a França precisa para fomentar a modernização e humanização do homem? Juntou-se a essas questões a apreciação dos valores culturais, as propostas científicas, a Língua e a Literatura, assim como, o ensino de Matemática e de Ciências. Tal investigação remeteu a revisão de ações educativas do século XIX.

Assim o ponto de partida adotado para esse estudo começa em 1802 quando a escola de ensino médio cumpria a função de formar as elites administrativas e intelectuais do país. A época, o Latim era a disciplina mais importante e o foco da educação se concentrava na área de humanas. Quanto a Matemática era trabalhada a parte de Geometria e figurava no fim do curso, por isso pouco estudada. A amplitude e profundidade desses conteúdos eram reservadas à elite. Nessa época pela primeira vez se cogitou socializar os conhecimentos de Geometria para a comunidade escolar, tornando-o prioridade ao lado do Latim. Dentre as considerações foi orientado que o ensino da disciplina tivesse cunho prático em detrimento do teórico, até então praticado nas escolas. Já a abordagem teórica ficaria reservada para o ensino secundário. Em 1833 a palavra Matemática ainda não estava configurada como corpus disciplinar no espaço escolar francês, de modo que seu ensino se ramificava em alguns campos conhecidos a época como Geometria, Desenho Linear, Topografia... .

Ainda dentro da Terceira República surge em 1882 a "Lei de Ferry"4, nela a palavra Matemática é introduzida na legislação de Educação do Ensino Primário, mas de forma tímida, através da expressão "Elementos das Ciências Matemáticas" a qual alcançou até o ensino básico superior 5 . Para os teóricos que participaram ativamente da legislação, a referida expressão refletia uma nova ambição em relação à formação intelectual que começava, conforme consideravam nos primeiros anos de escolarização. A Álgebra e a Aritmética já figuravam nos planejamentos escolares, e seguiam o modelo empírico. Esse aspecto priorizava a experiência sensorial, observação e a construção de uma educação matemática, uma cultura prática, com grau de exigência e eficiência consideradas satisfatórias. A mesma metodologia foi adotada na escola primária superior (curso Normal) para formar professores que atendessem as novas demandas.

Ao fim do século XIX as mudanças econômicas exigiram a modernização do paradigma de educação para atender novas demandas que surgiam. A escola é então chamada à responsabilidade na preparação de um novo protótipo de homem que atendesse a modernidade. Um novo projeto de educação é articulado com a Reforma (1902 - 1905), que através de um novo currículo buscou combinar as humanidades clássicas com as modernas ciências humanas. Nesse aspecto a Matemática foi beneficiada, alcançando um maior grau de importância. Como considera Émile Borel, para quem, "O ensino da Matemática deve partir de fatos da realidade do cotidiano para que os alunos possam perceber que não se trata de uma simples abstração". (BOREL, 1877).

Esse autor ainda considera a necessidade de um ensino consistente desde o primeiro ciclo, com utilização de material e ações concretas, focalizando experiências e observações, que priorize e desenvolva a parte indutiva, ficando para o segundo plano a parte dedutiva, a partir do encadeamento de raciocínios. Ele prossegue nas suas considerações dando credibilidade ao segundo ciclo, como aquele no qual deve ser introduzido novos conceitos relacionados com o estudo das funções e suas variações. A partir de então a Matemática passou a ser concebida como um lugar reconhecido na "educação geral da mente". Émile Borel procurou esclarecer à Reforma em 1904, em uma conferência para professores onde buscou apoio para cumprimento dos seguintes objetivos estabelecidos: - Propor a utilização de fatos cotidianos no ensino da Matemática, a fim de que o aluno não conceba o ensino como algo descontextualizado; - Dar relevância a Matemática como necessária na formação da educação; - Evitar a supressão de conhecimentos que poderiam ser considerados desnecessários; e por fim tornar o ensino mais prático e menos teórico.

Na contramão, a Reforma de 1923, do reformista Berard ${ }^{6}$ vai propor a retomada da educação clássica do século XIX indo de encontro às propostas anteriormente estabelecidas, o que não se consolidou. Contudo essa Reforma acontece em um período de guerra, e avança beneficiada pelas circunstâncias históricas.

\footnotetext{
4 Lei de autoria do Ministro Jules Ferry (1882-1893)que com suas leis, entre 1882 e 1883, reorganizou totalmente o ensino de francês, estabelecendo a escola obrigatória, gratuita e leiga. (Luzuriaga, 1990)

50 ensino básico superior corresponde ao ensino Normal brasileiro, formador de professores para atuarem no $1^{\circ}$ o segmento do ensino fundamental.

${ }^{6}$ Léon Berard - determinou a reforma do $1^{\circ}$ ciclo do ensino secundário e a obrigatoriedade do Latim na $6^{\underline{a}}$ série.
} 
Trata-se de um momento em que a França está mais nacionalista e deseja promover novas humanidades clássicas, o que culmina com a obrigatoriedade do ensino do Latim e consequente redução da carga horária de Ciências e de Matemática. Berard considerou que a perda da prioridade de humanidades clássicas no currículo foi como uma perda de identidade nacional.

0 referido modelo persistiu por um período significativo, apesar da queda de obrigatoriedade do Latim em 1925. Nesse período o ensino secundário ainda era caracterizado como uma educação cultural, liberal, desinteressada, o que excluía qualquer objetivo prático ou de perspectiva. Os esforços educacionais não foram suficientes para fazer mudanças significativas no ensino de Matemática, que encerra o século XIX com três diferentes programas escolares de acordo com os extratos sociais e status, como segue: - o primeiro tipo reservado a elite intelectual - incluía o ensino de Ciências ao final do curso. A tônica da formação persistia em uma educação clássica e humanista apesar de prejudicar parte dos alunos que tinham interesse em ingressar na École Polytechnique. O segundo e terceiro modelos de educação destinavam-se a formação de técnicos (gestores) para a área industrial e comercial.

Porém a visão educativa que antevinha a essa reforma triunfa, levando a França a experimentar um ensino enraizado na realidade, através do uso de atividades concretas ou material concreto. Mas quanto a formação dos mestres enfrenta um impasse - a questão de gênero. Trata-se de uma formação que se dá em classes distintas para homens e mulheres. Para essas o currículo é ligeiramente diferenciado, primando pelas humanidades clássicas e a prática de Matemática acontece sem experimentar o rigor e abstração trabalhada no currículo masculino. Tal diferencial outorga aos homens o título de bacharel ao fim do curso.

O quadro começa a mudar a partir de 1920 quando os programas de formação de professores passa a ser realizado desconsiderando-se a questão de gênero, e portanto, permitindo também as mulheres o alcance do título de bacharel. Contudo a Reforma da década de 1930, cognominada como Reforma Vichy ${ }^{7}$, ainda considera insuficiente a formação de profissionais de educação pela Escola Normal. Posteriormente a Terceira República, a França ainda contemplou o desdobramento da Reforma Vichy (1940 - 1944). Nela procurou-se reestruturar o sistema educacional francês, considerando que o mesmo estava afetado e comprometia o avanço educacional. Assim por razões políticas foram tomadas as seguintes medidas: _ encerradas as atividades da escola primária superior, responsável pela formação de professores que atendia o curso primário. A justificativa para essa perda era a de que essa agência formativa estava muito ligada a ideias republicanas. Os novos postulantes ao ofício teriam que cursar o ensino secundário em escolas mais modernas e alcançar a formação em bacharel, proposta que vigorou até o ano de 1965.

A partir de 1955 a Organização de Cooperação e Desenvolvimento Econômico (OCDE) ${ }^{8}$ passou a contribuir enfaticamente para a reforma do ensino de Matemática. Essa organização visando uma participação ativa e efetiva no processo, ocupou um escritório bem no centro de Paris para acompanhar de perto as negociações em torno da reforma. Antes de se transformar em uma importante organização já financiava reunião de especialistas, engenheiros e professores do ensino secundário, que culminou com o Encontro de Royaumont em 1959, do qual participaram figuras influentes como Choquet e Dieudonné. Com o avanço do movimento de reforma dos estudos de Matemática, o projeto alcançaria dimensão internacional.

Com o projeto da OCDE em ação, especialistas de diferentes disciplinas reuniram-se em torno da Matemática para estruturarem uma linguagem comum que os unissem. Assim conforme descreve Strauss (1954) "biólogos, linguistas, economistas e matemáticos, de repente se veem lado a lado favorecidos pela posse de um grande aparato conceitual que é a linguagem". Coube ao grupo Bourbaki a responsabilidade pela construção da reforma, da qual emergiram as seguintes ideias: 1ํ - apresentar uma noção central da estrutura da Matemática, que passou a ser prioridade, e um novo papel a ser desempenhado pela disciplina; $2^{-}$Justificar a Reforma como uma necessidade de modernizar a Matemática a qual deve ser explicada a partir de fatos reais.

Nesse aspecto Lévi-strauss enfatizou a necessidade do estruturalismo para a Matemática, o que estava em processo em todas as ciências, inclusive as humanas e sociais e que viviam naquele momento a

\footnotetext{
7 Na II Guerra Mundial a França foi derrotada pela Alemanha. O regime Vichy representou a força de resistência francesa em defesa de autonomia da pátria, da família e do trabalho. 0 que se realizou através da promulgação de uma nova constituição.

${ }^{8}$ É uma organização internacional, composta por 34 países e com sede em Paris, França. A OCDE tem por objetivo promover políticas que visem o desenvolvimento econômico e o bem-estar social de pessoas por todo o mundo.
} 
" mainstream" Filosófica 9 . Por isso a nova base sobre a qual se assentava os novos pilares da disciplina e que buscava consolidação do projeto de Matemática foi considerada como uma ferramenta científica e uma linguagem essencial para comunicação de todo o conhecimento. Tal evidência propiciou a convergência de matemáticos do grupo Bourbaki, filósofos e Psicólogos como Jean Piaget os quais passaram a se reunir na década de 1950 , e que culminou com a criação da Comissão Internacional para o Estudo e Aperfeiçoamento da Matemática (CIEAEM).

Ao fim desse período uma nova comissão designada por " Commission Lichnerowicz" retomou a reforma: a reforma da "Matemática Moderna". Nesse aspecto foi dado o primeiro passo que foi o estabelecimento em dezembro de 1966, da Comissão Ministerial para o estudo da Educação Matemática, presidida por André Lichnerowicz. Essa reforma foi baseada na crítica do ensino de Matemática tradicional representado pela Geometria Clássica, considerada como uma ciência muito distante para a formação atual, um ensino ultrapassado. A nova meta era que a Matemática devia desempenhar um papel de liderança no desenvolvimento da ciência e da tecnologia, incluindo as ciências humanas e Sociais. Todas versando temas da atualidade. Quanto a Matemática, apesar das orientações, continuou seguindo o modelo de ensino de 1950 através da priorização do estudo de álgebra dos conjuntos, regras de estruturas, formalismo, ao lado da probabilidade e estatística.

Em 1970, durante o trabalho de organização curricular da educação Básica, ficou constatado que faltava aos professores melhor formação para atender a proposta nacional. Essa consideração desestruturou os mentores do novo currículo. A partir de então, dentro e fora da academia, físicos e matemáticos passaram a criticar o documento em construção, criticando o domínio das abordagens formais e abstratas presentes na Matemática Moderna. Por fim concluíram que tal formalismo e abstração não eram produtivos para a grande maioria de alunos e professores, mas que esse modelo estava em consonância com a formação de futuros físicos e engenheiros. As discussões em curso levaram esses profissionais a buscarem um novo modelo. Novamente a educação clama por reforma. E dessa vez com a conscientização de parte considerável dos educadores e físicos.

Agora por se tratar de uma reforma desejada foi amplamente apoiada na França. 0 programa trouxe novas orientações para o ensino da Matemática na educação primária e secundária. Também estabeleceu um sistema de formação de professores através de instituições específicas. Apesar da aceitação houve dificuldade na implementação da reforma. Constatou-se que menos de $20 \%$ dos professores de Matemática eram concursados, e os $80 \%$ restantes estavam distribuídos entre professores auxiliares, muitas vezes não licenciados nessa disciplina, ou aqueles que provieram de antigos cursos adicionais primários, sem a qualificação necessária para o exercício da profissão.

Com a universalização do atendimento escolar foi proposto um currículo único tanto para os alunos que tinham a intenção em atuar no mercado de trabalho quanto para os que ensejavam uma carreira no ensino superior. Novamente há um descontentamento. A elite discorda de tal modelo e reivindica outro que atenda em maior qualificação. Essa circunstância desconstruiu as tradições herdadas pelo ensino primário, que foram abandonadas, e em seu lugar foram colocadas em prática as metas do ensino secundário. Ocorre que essa medida foi dificultada pela falta de um número significativo de professores com melhor formação, o que gerou um descompasso. Tal constatação provocou uma ampla discussão entre os Matemáticos e Físicos, dentro e fora da comissão. Nas discussões foram criticadas as abordagens formais e abstratas estabelecidas pelo programa de Matemática que foram consideradas inapropriadas para uma grande maioria de alunos despreparados.

Em busca de uma estrutura e enfrentamento do problema houve uma mobilização nacional, matemáticos e professores de Matemática se organizaram individualmente e coletivamente através da Associação de Professores de Matemática do Ensino Público (APMEP). As salas de aulas foram transformadas em grandes laboratórios, através de reflexão e experimentação, que seguiam as orientações da proposta de mudanças. Tinha tudo para dar certo, mas o projeto seguia sem que houvesse atenção à formação de professores param o novo modelo, justamente os atores que poderiam colaborar para o êxito da proposta, o que se constitui um entrave nos anos de 1970. Em face dos desencontros, falta de objetivos comuns, Lichnerowicz renunciou em 1973 e a comissão não conseguiu concluir a segunda etapa da reforma.

\footnotetext{
9 Mainstream é um conceito que expressa uma tendência ou moda principal e dominante. A tradução literal de mainstream é "corrente principal" ou "fluxo principal"
} 
Em 1975 ocorre a última etapa de reformas estruturais, que ficou conhecida como Reforma Haby ${ }^{10}$. Essa reforma fez diversas intervenções no ensino colegial e superior, apresentando outra visão de Matemática e, ao mesmo tempo, criticou a posição dos reformadores da Matemática Moderna e suas ambições na universalização do ensino. Para esse reformista e equipe,

Existem dois tipos de Matemática, dois tipos de cultura Matemática. Uma é a Matemática concreta que conduz a "aquisição" de técnicas computacionais, útil para todas as empresas, muitas vezes essencial - essa é a Matemática para todos. Já a Matemática Moderna "abstrata" é para aqueles que formam a mente, aqueles que podem "dominar" as técnicas de computação. Esse modelo de ensino é reservado para aqueles que, pela sua capacidade, desejam prosseguir os estudos de alto nível.

Apesar dos esforços a Reforma Haby não obteve apoio das faculdades, que não concordarem com a nova proposta, e por isso mantiveram os programas de 1977 atrelado as ambições de alcance da Matemática Moderna. Mesmo assim os trabalhos de Bourbaki, cujo projeto orientou os estudos matemáticos na proposta do Movimento de Matemática Moderna e que foram reforçados por estudos de psicólogos da época, como os de Jean Piaget, não alcançou o êxito desejado. Na análise desse psicólogo, a maneira que o Movimento de Matemática Moderna chegou aos alunos, pouco ou nada contribuiria com o ensino da Matemática. Para ele

O triste paradoxo que nos apresenta o excesso de ensaios educativos contemporâneos é querer ensinar Matemática "moderna" com métodos na verdade arcaicos, ou seja, essencialmente verbais e fundados exclusivamente na transmissão mais do que na reinvenção ou na redescoberta pelo aluno. Em outras palavras, a iniciação à Matemática Moderna não pode ser confundida com uma entrada no chofre em sua axiomática. Na realidade, só é possível axiomatizar um dado intuitivo prévio, e psicologicamente, uma axiomática só tem sentido a título de tomada de consciência ou de reflexão retroativa, o que supõe toda uma construção proativa anterior. A criança desde os 7 anos e o adolescente manipulam o tempo todo operações de conjuntos, de grupos, de espaço vetorial etc., mas não tem qualquer consciência disso, pois esses são esquemas fundamentais de comportamento e depois de raciocínio, muito antes de poderem ser objetos de reflexão. Toda uma gradação é, portanto, indispensável para passar da ação ao pensamento representativo e uma não menos longa série de transições contínua sendo necessária à reflexão sobre o pensamento. 0 último escalão é então a passagem da reflexão à axiomatização propriamente dita (Piaget, 1998, p.221)

Essa reforma também enfrentou algumas dificuldades por conta de suas exigências. Uma delas diz a respeito a sua implementação, já que deveria ser aplicada a todos os alunos, independente de escola, de carreira social, e a todos os níveis de estudo - da educação infantil a universidade. Para tal alcance, o Ministério de Educação foi incumbido de organizar um currículo único com desdobramentos do primário a faculdade. A época a APMEP lançou o slogan " Matemática para todos, do Jardim de Infância à Sobornne".

Mas há um resultado positivo nessa reforma, é que a proposta de Haby deixou a descoberto o despreparo da Comissão Lichnerowicz que deveria atender o objetivo de "democratização", mas que se ateve a uma reforma para cursos de curta duração e por isso recebeu duras críticas. Um participante dessa comissão chegou a questionar à equipe sobre a visão educativa do grupo a partir da seguinte frase: " devemos ensinar Matemática ultrapassada para as crianças menos inteligentes?". Tal fato se tornou em uma tese equivocada para aquela comissão que era formada por personalidades da antiga ordem secundária, e que por isso não tinha nenhuma experiência no "ensino primário".

Em 1980, André Revuz"11 escreveu um livro com título provocador, a saber: "É possível ensinar Matemática?" Nessa obra ele descreve um quadro sombrio sobre o ensino. A ideologia do livro funcionou

10 Essa reforma teve por objetivo a modernização do sistema educativo (pour une modernisation de système educatif). A Lei foi promulgada em 11/07/1975.

11 Professor honorário de Matemática da Universidade Diderot Paris 7, membro da Commission Internationale de L'Enseignement Mathemátique de 1967 a 1970. Foi o primeiro diretor do Commission on Matehmatical Instruction da França. Desempenhou um papel importante no desenvolvimento e na implementação da reforma "Matemática Moderna" na França. 
como um alerta a comunidade educacional francesa. Dessa forma de 1980 a 2000 novos ingredientes são lançados para uma formação básica sustentável. E atendendo as exigências dos programas da década de 1980 tanto o ensino médio como as faculdades buscam atualizar o ensino comprometendo-se a priorizar do método intuitivo ao formalismo, através de uma abordagem pedagógica de experiência e ação. Novas diretrizes, novos ramos e novas ferramentas matemáticas conquistam lugar de destaque nos programas. Dentre elas o estudo de Estatística em conexão com a Física, Biologia e os fatores econômicos. As calculadoras passam a ser consideradas como material escolar de uso cotidiano. Por isso indispensável às aulas. 0 seu uso altera as práticas de cálculos e também permite construir algoritmos simples. 0 ensino de Geometria é direcionado para um "método plenamente experimental", ficando o estudo da formalização para o ensino médio. Em resumo, os programas oficiais em vigor a partir de 1981 estabeleceram no ensino uma concepção de educação e cultura matemática, o seguinte:

- evitar o formalismo e abstração, a priori, para prevenir a evasão de alunos;

- introduzir idéias e problemas da vida real, a fim de dar sentido e legitimidade a essas noções;

- trabalhar a contextualização da Matemática com outras disciplinas;

- desenvolver o uso da calculadora e software (geometria dinâmica, planilha, plotter);

- Fornecer marcos da História da Matemática “(...) que deve melhorar o conteúdo cultural da Matemática, em particular a introdução de uma perspectiva histórica que pode ajudar os alunos a compreender melhor o significado e o alcance dos conceitos e problemas estudados (...)".

Em 1999, a pedido da APMEP, o Ministério de Educação elegeu uma comissão para fazer um balanço sobre o ensino da Matemática e estabelecer propostas para o novo milênio. Os eleitos buscaram nortear o trabalho a partir da frase "Por que ensinar Matemática?". Os resultados são aqui conhecidos: a equipe reiterou a necessidade dos estudos de Matemática contextualizada com Física, Biologia e Economia. Ressaltou a necessidade do fortalecimento do binômio imaginação/raciocínio incrementados pela abordagem da disciplina para desenvolvimento e formação consistente. Além disso, foram relevadas as disciplinas como Geometria, Computação, Cálculo, Probabilidade e Estatística. Questionou-se sobre os subsídios ou vantagens que esses conhecimentos podem dar aos jovens, capacitando-os para o enfrentamento de problemas, de prevenção de problemas futuros, de equacionamento de problemas cotidianos.

Por fim a missão concluiu que o ensino da Matemática é por natureza um pensamento de longo prazo em descompasso com a versão geral da juventude, pais e professores em suas práticas, que é de curto prazo. Somou-se a essas observações a constatação de escassez de professores em muitas áreas e ainda a provisão de computadores nas escolas, que tem sido realizado de forma irregular. Soma-se a isso a questão das classes escolares que estão cada vez mais heterogêneas e tem dificultado a atuação didática dos professores.

Ao apreciar o balanço Gispert (2014) considera que quando se mergulha no documento fornecido pela Direção-Geral da Educação escolar intitulado como "Base Comum de Conhecimentos e Competências" (Handbook, set, 2000) é possível perceber a falta de orientação dos professores. O documento é considerado como catálogo que norteia o lidar com múltiplas tarefas simultaneamente. Ao que parece está caminhando, mas longe de alcançar os objetivos da Matemática.

\section{CONCLUSÃO}

A França, país comprometido com uma educação de qualidade busca desde os primórdios do século XX combinar as humanidades clássicas com as ciências. Partindo dessa visão dá início à construção do ensino contextualizado, trazendo para a sala de aula, fatos reais e do cotidiano. A Geometria parece assumir o principal papel na aprendizagem de Matemática por propiciar a utilização de procedimentos práticos. 0 que se dá mesmo antes da Matemática se tornar um corpo disciplinar. 0 ensino era oferecido em suas ramificações, como a Geometria, a Álgebra e a Aritmética. No Brasil essas disciplinas eram consideradas como as matemáticas e foi fruto de profícuas discussões em torno de sua unificação. Um fato chama atenção sobre o modelo de ensino francês que é a defesa em quase todo o processo de reforma do século $\mathrm{XX}$, de um ensino indutivo, que parta da prática para a teoria. O modelo empírico parece dominar as séries iniciais, preparando os alunos para compreenderem conceitos e demonstrações futuras. Quanto aos professores há uma preocupação do governo com a qualidade de formação o que se efetiva com a mudança da escola primária superior para o ensino secundário. Contudo a maior contribuição acontece após as guerras mundiais quando o ensino de Matemática é pensado por um grupo de peritos de 
formação inquestionável. Assim Filósofos, Psicólogos e Matemáticos buscam uma estrutura que lhes forneça uma base comum através de uma linguagem, o que foi propiciado a partir dos trabalhos acadêmicos do grupo Bourbaki. Os estudos alcançam o nível de estrutura desejado, e servem de base para a criação da Comissão Internacional para Estudo e Aperfeiçoamento de Matemática (CIEAEM). A nova abordagem se espalha pelo mundo. 0 Brasil adota o novo modelo a partir da década de 1960. Apesar de ser um projeto que tinha tudo para dar certo, não avançou em nenhum dos países. Como observa Jean Piaget, principal estudioso de Psicologia para a Matemática Moderna, para quem tal ensino era praticado a partir de métodos arcaicos. A reforma de 1975 corrobora com Piaget ao constatar o despreparo dos professores para esse alcance. Com esse histórico a década de 1980 inaugura uma nova página na educação francesa.0 primeiro passo se dá com o lançamento do livro de título "É possível ensinar Matemática?", de André Revuz. Essa produção inspirou a reestruturação escolar da época, agora trazendo à tona a preocupação com a evasão escolar. Nesse aspecto o foco educacional se desloca de "como se ensina" para "como se aprende", o que é um ganho. Contudo é mantido o objetivo do ensino de Matemática, a priori indutivo, caminhando e direção a conceitualização e dedução, ingredientes necessários a educação consistente. Em 1999, o Ministério de Educação francês, através de uma comissão de estudos faz levantamento de um século de educação, com vista a lançar luz nos procedimentos de Matemática do terceiro milênio, e chega as seguintes conclusões: - a questão do descompasso entre metodologias e turmas heterogêneas continuará exigindo dos professores novas práticas educativas, entre elas a de contextualizar o ensino. É preciso reinventar. A necessidade de atender de forma regular à implantação e manutenção das mídias necessárias as atividades escolares. E ainda introduzir as perspectivas da história da disciplina para melhorar o entendimento dos significados e conceitos abordados. Os avanços na educação francesa colaboraram também com a educação brasileira em busca de um padrão de qualidade. Com a Lei de Diretrizes e Bases (LDB 9394/96) foi estabelecido o Plano decenal de Educação (PDE) permitindo a revisão e ajustes necessários para corrigir o curso em suas necessidades a cada dez anos. Quanto à França continuará sendo um exemplo de atualização e realização no campo educacional.

\section{REFERÊNCIAS}

[1] Berard, L. Homme Politique. fr.wikipedia.org.wiki/Léon_Berard. Acesso em 30 de abril de 2016.

[2] Berti, N. M. O ensino de matemática no Brasil: buscando uma compreensão histórica.In http://www.histedbr.fe.unicamp.br/acer histedbr/jornada/jornada6/trabalhos/617/617.pdf, acesso em 15 de março de 2016.

[3] Borderíe, R. Les grands noms de l'eduction. Editions Nathan/ Vuef, 2001. Isbn: 2-09-191151-8

[4] Borel, Pétrus. Madame Putiphar. Tome Premier. (2ª Edição). Paris: Léon Willem, Éditeur, 1877. Domínio Público via Internet Archives: http://www.archive.org.

[5] Dassie, B. A.; Rocha, J. L. O ensino de Matemática no Brasil nas primeiras décadas do século XX. In. http://www.uff.br/dalicenca/images/stories/caderno/volume4/da Licena Bruno.pdf , acesso em 05 de março de 2016.

[6] Gispert, H. (Éd.), La France mathématique de la Troisième République avant la Grande Guerre, Paris: Société mathématique de France, 2015.

[7] Gispert, H. Mathematics education in France, 1980 - 1980. In A. Karp \& G. schubring (Eds.) Handbook on the History of Mathematics Education, pags. 229 - 240, 2014.

[8] Gispert, H. Two mathematics reforms in the context of twentieth century France: Similarities and differences. International Journal for the History of Mathematics Education, 4, 43-50, 2009.

[9] Gispert, H., Hulin, N., Robic, M.-C. (eds.), Science et enseignement. L'exemple de la grande réforme des programmes du lycée au début du XXe siècle. Paris: Vuibert \& INRP, 2007.

[10] Les cent ans de L"Enseignement Mathématique (1899 - 1999). L”Enseignement Mathématique no 45, p. 3-4, 1999.

[11] Luzuriaga, L. História da educação e da pedagogia. 18. Ed. São Paulo: Nacional, 1990

[12] Novaes, B. N. D., Pinto, N. B., França, I. S. Estruturalismo e Matemática Moderna: Dilemas e implicações para o ensino. In http://www.pucpr.br/eventos/educere/educere2008/anais/pdf/653 790.pdf , acesso 15 de fevereiro de 2016.

[13] Piaget, J. Sobre a Pedagogia: Textos inéditos. São Paulo: Casa do Psicólogo, 1998.

[14] Portier, P. Regulação Estatal da Religião na França (1880 - 2008) Ensaio de Periodização. Revista de Estudos da Religião setembro, pp. 24-47 ISSN 1677-1222, 2010. 


\section{Capítulo 6}

A leitura do ambiente como ponto de partida para a educação ambiental integrada ao ensino de Matemática

Daniana de Costa

Edilson Pontarolo

Resumo: A problemática relacionada às questões ambientais surgiu nas últimas décadas do século XX como uma crise ambiental oriunda da acumulação de capital, maximização de lucro em curto prazo e formas de consumo que conduziram à exploração da natureza afetando até mesmo as condições de regeneração dos ecossistemas naturais. Desse modo, as ações humanas no meio ambiente acabaram por criar uma situação limite para a sobrevivência sadia no Planeta. Ao considerar a crise ambiental, suas implicações e como o homem se relaciona com o ambiente, verifica-se que é de extrema importância a prática da Educação Ambiental nos diversos espaços da sociedade a fim de que a relação homem ambiente seja repensada. Nesse sentido, foi planejada e desenvolvida a prática pedagógica Leitura do Ambiente para a introdução da temática ambiental na disciplina de matemática visto que a temática ambiental ainda é comumente explorada em disciplinas como Ciências e Geografia. 0 público-alvo foi composto por 79 estudantes de quatro turmas do 9o ano do Ensino Fundamental de uma escola municipal localizada na zona urbana do município de São Lourenço do Oeste, SC. A prática pedagógica ocorreu nos ambientes internos e arredores da escola e foi socializada por meio de registros fotográficos obtidos pelos estudantes. Além de tal prática ter permitido a introdução da temática ambiental na disciplina de matemática, as concepções de meio ambiente evidenciadas nas imagens geraram discussões entre os estudantes e lhes despertaram o interesse quanto à temática ambiental contribuindo para a condução da prática da Educação Ambiental na disciplina de matemática em atividades que foram desenvolvidas posteriormente a esta.

Palavras-chave: Educação Básica; Educação Ambiental; Análise de Fotografias; Concepção de Meio Ambiente. 


\section{INTRODUÇÃO}

Apesar dos Parâmetros Curriculares Nacionais (PCN) indicarem o tratamento das questões ambientais de maneira transversal no Ensino Fundamental, da Política Nacional de Educação Ambiental (PNEA, Lei № 9.597/99) tratar que a Educação Ambiental deve estar presente de maneira articulada, contínua e interdisciplinar em todas as modalidades de ensino formal e não formal, e das Diretrizes Curriculares Nacionais para a Educação Ambiental (DCNEA) reafirmarem e evidenciarem a obrigatoriedade da Educação Ambiental tanto na Educação Básica quanto no Ensino Superior (BRASIL, 1997, 1999, 2012), no contexto escolar, a Educação Ambiental vem sendo praticada esporadicamente por meio de projetos pontuais ou apenas em disciplinas como Ciências e Geografia.

Diante do exposto, surgem questionamentos por parte dos docentes sobre como tratar do tema Meio Ambiente de modo transversal na disciplina de matemática, conforme está proposto pelos PCN, tendo como foco a prática da Educação Ambiental no contexto escolar assim como está preconizado na PNEA e nas DCNEA. De acordo com a proposta dos PCN os temas transversais são prescritos como comuns a todas as disciplinas, ou seja, permeiam transversalmente as diferentes áreas do saber (CUNHA, 2007).

Nesse sentido, este trabalho relata uma prática pedagógica cujo intuito foi introduzir a temática ambiental transversalmente na disciplina de matemática em quatro turmas de 9o ano do Ensino Fundamental de uma escola municipal de São Lourenço do Oeste, SC. Este trabalho foi apresentado previamente no XIII EDUCERE Congresso Nacional de Educação, na PUC-PR, Curitiba, PR, 2017.

\section{MEIO AMBIENTE E EDUCAÇ̃̃O AMBIENTAL NO CONTEXTO ESCOLAR}

À medida que os efeitos adversos do processo de desenvolvimento industrial capitalista foram se agravando na vida cotidiana devido a Revolução Industrial e ganhando espaço nas ciências e nos meios de comunicação de massa, o homem passou a voltar seu pensamento para as questões ambientais. Assim, começaram a surgir os marcos legais sobre a Educação Ambiental por meio das Conferências da ONU. No ano de 1972, em Estocolmo, Suécia houve a primeira Conferência sobre Meio Ambiente Humano para discutir sobre os problemas ambientais. Na oportunidade surge, pela primeira vez, a definição de Educação Ambiental devido à importância da ação educativa referente às questões ambientais.

Daquele momento em diante, a discussão sobre Educação Ambiental se intensificou em âmbito mundial. Em 1977 na Conferência Intergovernamental sobre Educação Ambiental em Tbilisi, ex-URSS, organizada pela UNESCO e PNUMA (Programa das Nações Unidas para o Meio Ambiente) foram dadas as definições, os objetivos, os princípios e as estratégias para a Educação Ambiental até hoje adotados em todo o mundo.

Para o tratamento da Educação Ambiental no contexto escolar brasileiro, em 1997, os Parâmetros Curriculares Nacionais foram publicados pelo MEC para indicar o tratamento das questões ambientais de maneira transversal no Ensino Fundamental. Em 1999 foi aprovada a Lei № 9.597 que institui a Política Nacional de Educação Ambiental para o avanço da Educação Ambiental no contexto educacional e em 2012 foram estabelecidas as Diretrizes Curriculares Nacionais para a Educação Ambiental reafirmando a relevância e a obrigatoriedade da Educação Ambiental na Educação Básica e Superior, além do seu enfoque interdisciplinar (BRASIL, 1997, 1999, 2012).

Dentre as perspectivas de Educação Ambiental, destacam-se a Conservadora e a Crítica, oriundas de uma multiplicidade de visões de mundo. A perspectiva Conservadora sustenta uma relação desintegrada entre sociedade e natureza, baseada na dominação da primeira sobre a segunda, que não supera o cientificismo cartesiano e o antropocentrismo e estando fundamentada em uma visão fragmentada da realidade, com dificuldade em pensar a totalidade complexa, levando em conta que a transmissão do conhecimento "correto" fará com que o indivíduo compreenda a problemática ambiental para que seu comportamento e a sociedade sejam transformados (GUIMARÃES, 2004).

Em contrapartida, segundo Guimarães (2004), a perspectiva Crítica subsidia uma leitura de mundo mais complexa e instrumentalizada no intuito de contribuir para a transformação da complexa realidade socioambiental que implica no fomento do pensamento crítico e reflexivo face às condutas automatizadas, próprias do pragmatismo e do utilitarismo da sociedade atual.

Nesse sentido, é importante que o professor, em sua práxis, conduza seus educandos a refletir frente aos problemas ambientais, levando-os a encarar o desafio de repensar o modo como a humanidade enxerga e se relaciona com o meio ambiente.

Portanto, em se tratando de como a humanidade enxerga e se relaciona com o meio ambiente, destaca-se a necessidade de levar em conta a percepção dos estudantes quanto ao meio ambiente. 
Não há consenso na literatura sobre o conceito de meio ambiente. Para Raynaut (2004, p. 27), a noção de meio ambiente "[...] integra o ser humano, individualmente ou coletivamente, como ocupante e utilizador de um espaço e do conjunto de objetos e seres bióticos e abióticos que abarca". Em contrapartida, Reigota (2007) afirma que o termo meio ambiente indica uma amplitude maior do que a noção de ecossistemas, ou sistemas físicos ou biológicos, pois tal conceito considera a inserção humana como parte desse espaço interagindo com os demais componentes, além de levar em conta a dimensão social em seus vários aspectos, por exemplo, o histórico, o cultural, o político e o econômico.

Diante do proposto pelo autor, pode-se dizer que o conceito de meio ambiente é subjetivo, pois depende da forma como cada indivíduo percebe o meio ambiente levando em conta que cada sujeito o delimita a partir de suas representações, informações específicas, experiências e vivências cotidianas em seu tempo e espaço. Por conseguinte, ainda conforme Reigota (2007), na concepção antropocêntrica de meio ambiente, fruto da formação cartesiana, o homem é considerado como centro e ser mais importante do ambiente, portanto o foco está na utilidade dos recursos naturais para a sobrevivência do ser humano. Assim, o ambiente é visto como fonte de recursos ambientais a serem explorados para garantir melhor condição de vida para si, logo se evidencia uma postura individualista e quase sem compromisso socioambiental.

Segundo a concepção naturalista, o meio ambiente é concebido como o entorno natural, ressaltando-se conceitos como ecossistema, habitat, ecologia e sustentabilidade ambiental, por exemplo. O ser humano é um observador passivo que estaria fora do contexto da fauna e da flora e do meio abiótico não tendo, portanto, fortes laços de pertencimento.

Por outro lado, segundo a concepção globalizante, o homem/sociedade e a natureza tecem relações de reciprocidade levando em conta não só os aspectos naturais, mas também os aspectos políticos, sociais, econômicos, históricos, filosóficos e culturais do ambiente.

\section{METODOLOGIA DA PRÁTICA PEDAGÓGICA}

A prática pedagógica “Leitura do ambiente”, inspirada em Carvalho (2008), foi realizada na Escola Básica Municipal Irmã Cecília, localizada na zona urbana de São Lourenço do Oeste, SC durante o segundo semestre letivo de 2016 nas aulas regulares da disciplina de matemática em quatro turmas do $9^{\circ}$ ano do Ensino Fundamental tendo como participantes 79 alunos com idade entre 13 e 17 anos.

A referida prática ocorreu nos ambientes interno e externo à escola para introduzir a temática Meio Ambiente de maneira transversal (BRASIL, 1997) na disciplina de matemática com o objetivo de que os estudantes observassem o ambiente e o fotografassem (Figura 1) ${ }^{12}$ para assim demonstrar sua concepção de meio ambiente por meio do registro fotográfico.

Figura 1 - Estudantes do $9^{\circ}$ ano fotografam o ambiente nos arredores da escola

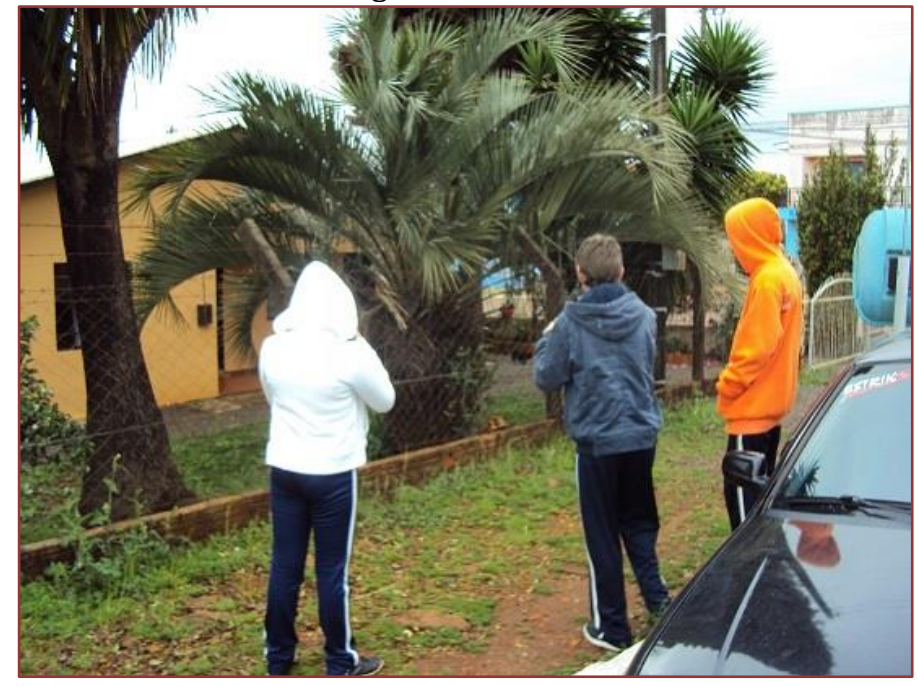

Fonte: Os autores.

\footnotetext{
12 A divulgação de imagens pessoais dos estudantes participantes foi autorizada pelo responsável legal mediante assinatura do Termo de Consentimento para Uso de Imagem e Som de Voz (TCUISV), incluso em projeto previamente aprovado pelo Comitê de Ética em Pesquisa da instituição de vínculo dos autores.
} 
As imagens fotografadas foram socializadas em sala de aula por meio de slides dando início a uma discussão sobre a concepção de meio ambiente entre a professora e os estudantes. Posteriormente, os estudantes selecionaram parte das fotografias e confeccionaram painéis que foram expostos em diferentes locais do ambiente escolar, conforme ilustrado na Figura 2.

Figura 2 - Painel confeccionado pelos estudantes com as fotografias selecionadas pelos estudantes

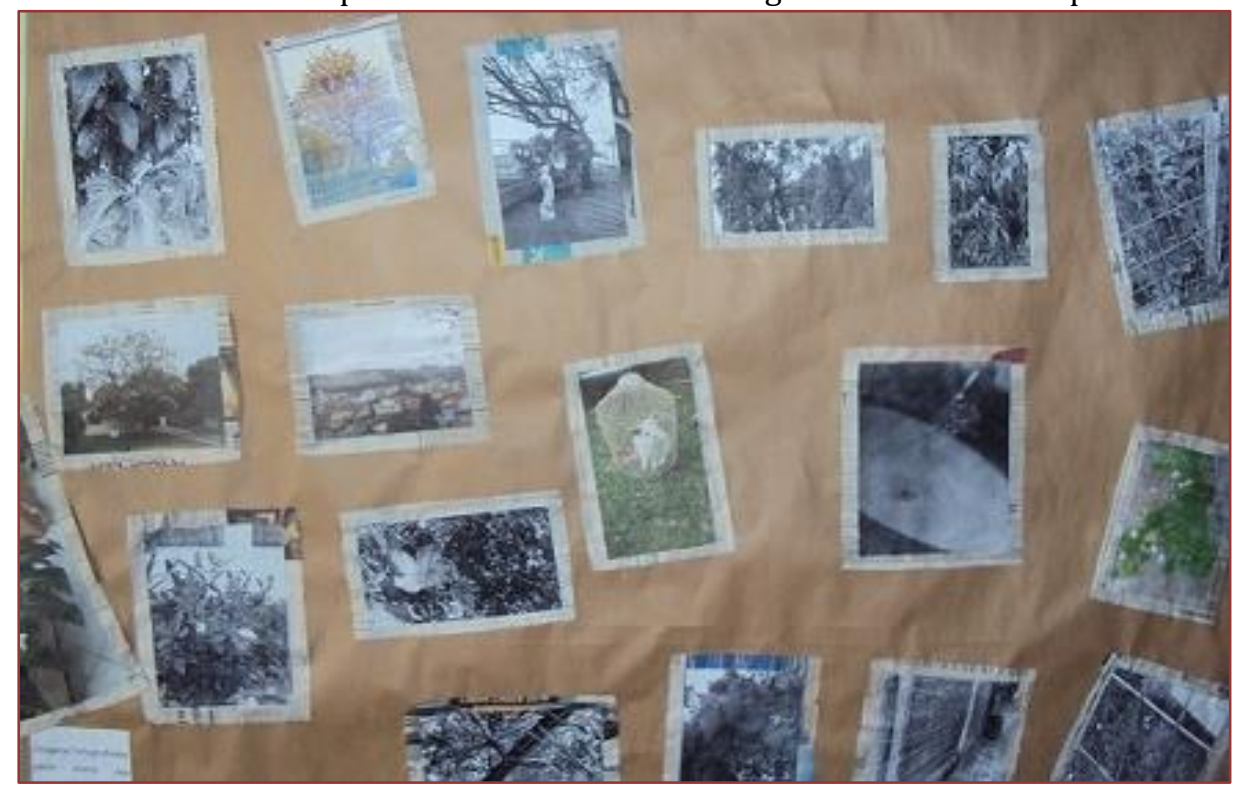

Fonte: Os autores.

\section{RESULTADOS E DISCUSSÕES}

Nas Figuras 3, 4 e 5 são apresentadas algumas fotografias produzidas pelos participantes durante a atividade Leitura do Ambiente, as quais foram empregadas para análise neste trabalho.

\section{Figura 3 - Árvores nos arredores da escola e troncos de árvores cortados em residência próxima}

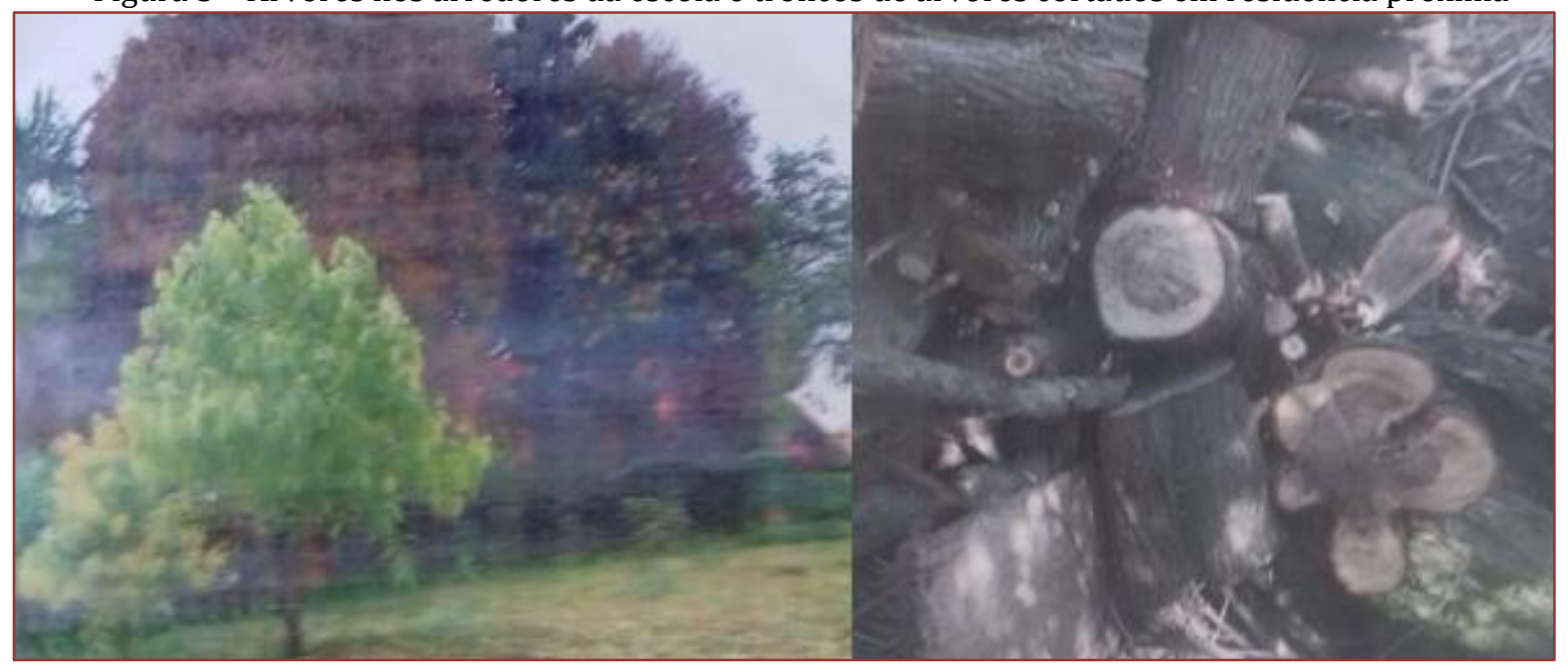

Fonte: Participantes da prática pedagógica.

Os dados analisados referem-se ao conteúdo das imagens fotografadas pelos estudantes durante a prática pedagógica, ou seja, os textos visuais (MAUAD, 2005) com o intuito de articular a discussão teóricometodológica sobre concepções de meio ambiente a uma análise da linguagem fotográfica relativa à modalidade de registro visual. 
Figura 4 - Lixo jogado no canteiro da rua e em terreno baldio

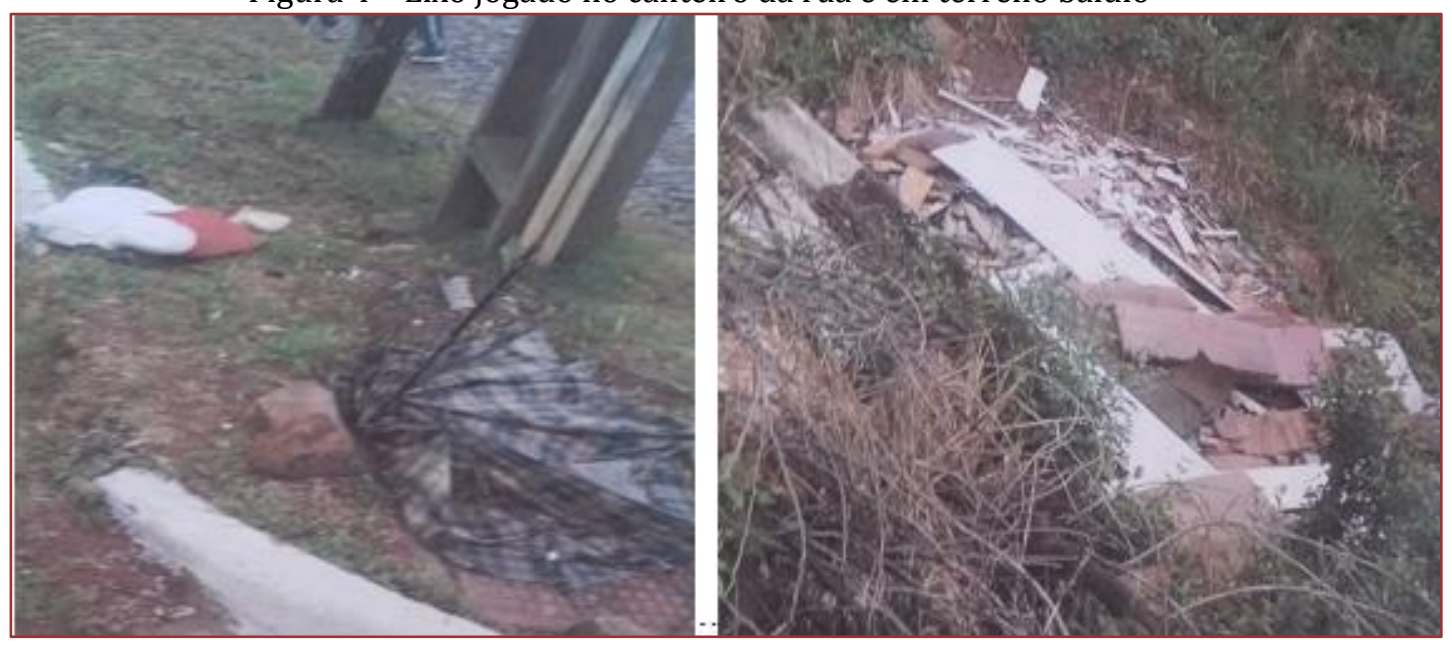

Fonte: Participantes da prática pedagógica.

Ao observarmos as fotografias registradas pelos estudantes, notames verificamos que há elementos comuns em destaque os quais pertencem à natureza, tal como árvores (Figura 4), flores e água (Figura 5), o que demonstra uma concepção naturalista de meio ambiente por parte dos participantes.

Figura 5 - Flores no pátio da escola e açude próximo à residência de um dos estudantes
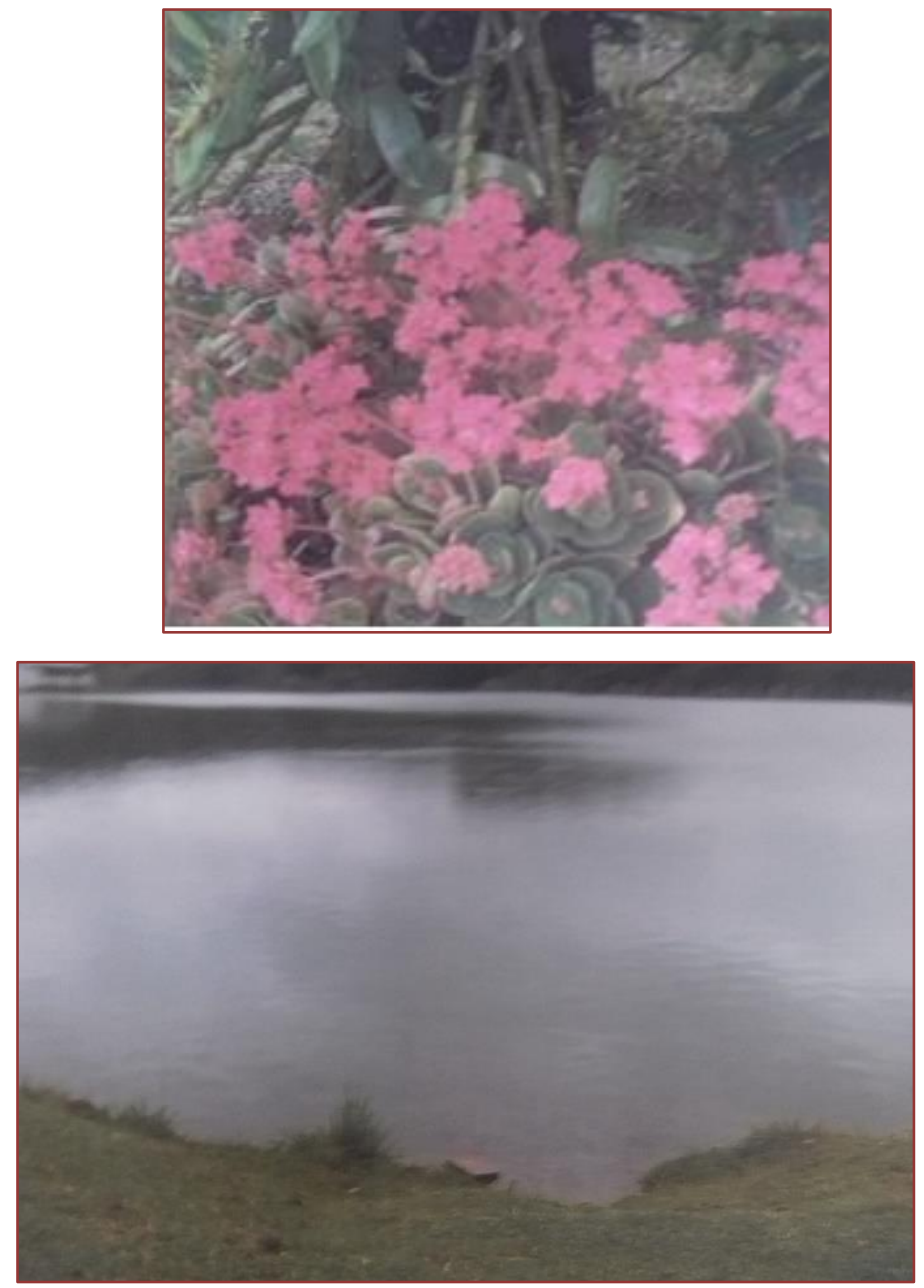

Fonte: Participantes da prática pedagógica. 
Os troncos de árvores cortados (Figura 4) evidenciam natureza como sendo apenas uma fonte de recursos a serem utilizados pelo ser humano, o lixo jogado em terreno baldio e no canteiro da rua (Figura 5) aponta para a superioridade do homem em relação à natureza, ou seja, o homem considera-se à parte da natureza e isto é demonstrado pela atitude desrespeitosa do homem para com a natureza. Logo, inferimos que estes registros visuais indicam uma concepção antropocêntrica do meio ambiente.

Inicialmente os estudantes mostraram certo estranhamento frente ao desenvolvimento desta prática pelo fato de não ser tão comum na disciplina de matemática. Apesar disso, a prática pedagógica propiciou indagações e uma discussão muito positiva entre os estudantes e a professora visto que apesar do tema parecer muito comum, se depararam com situações inesperadas durante a realização da atividade como, por exemplo, se o ser humano ou animais poderiam ser fotografados. Muitos estudantes não queriam ir para o centro da cidade pelo fato de afirmar que existe "pouca natureza" devido a ocupação pelas construções (casas, ruas, calçadas). Desse modo estes discursos durante a realização da atividade indicam que a concepção naturalista e antropocêntrica de meio ambiente está muito arraigada nos estudantes, de tal maneira que o que ficou em destaque nas fotos foram os aspectos biológicos e eles mesmos não conseguiam se enxergar como parte do meio ambiente.

\section{CONSIDERAÇõES FINAIS}

Ainda que a temática ambiental seja discutida com mais frequência em disciplinas como Ciências ou Geografia, verifica-se que essa problemática não deve pertencer apenas a algumas disciplinas. É importante que todos os docentes estejam engajados neste propósito, portanto torna-se fundamental a abordagem do tema Meio Ambiente tratado de modo transversal para a prática da Educação Ambiental, inclusive na disciplina de matemática.

A prática pedagógica relatada neste trabalho, além de ter permitido a introdução da temática ambiental na disciplina de matemática, se mostrou válida, pois serviu para gerar discussões sobre a temática ambiental e diagnosticar a concepção de meio ambiente dos estudantes.

Diante dos resultados obtidos, podemos dizer que prevalece uma perspectiva naturalista e antropocêntrica entre os estudantes em detrimento de uma perspectiva globalizante de meio ambiente. Nesse sentido, podemos inferir que a Educação Ambiental, no contexto escolar destes estudantes, ainda tem sido trabalhada em uma perspectiva Conservadora.

Nesse sentido, acreditamos que a concepção de meio ambiente dos estudantes contribui para que o professor tenha uma orientação quanto ao desenvolvimento de um trabalho com Educação Ambiental pelo fato de que estas concepções podem servir como um ponto de partida para uma prática de Educação Ambiental haja vista as perspectivas Conservadora ou Crítica de Educação Ambiental que perpassa a prática deste professor.

Esperamos que este relato contribua para ampliar a discussão entre os docentes das diversas disciplinas quanto o tratamento da Educação Ambiental no contexto escolar, visto que a relação do homem com ambiente depende muito da maneira como a Educação Ambiental vêm sendo praticada nas escolas, pois neste espaço há a possibilidade de dialogar e refletir sobre o meio ambiente, as ações do homem e suas implicações.

\section{REFERÊNCIAS}

[1] Brasil. Ministério da Educação. Secretaria de Educação Fundamental. Parâmetros Curriculares Nacionais: Meio Ambiente. Brasília: MEC, 1997.

[2] Brasil. Lei no 9.795, de 27 de abril de 1999. Dispõe sobre a educação ambiental, institui a Política Nacional de Educação Ambiental e dá outras providências. Diário Oficial da União. Brasília, 28 abr. 1999.

[3] Brasil. Ministério da Educação. Diretrizes Curriculares Nacionais para a Educação Ambiental. Brasília: MEC, 2012.

[4] Carvalho, I. C. M. Educação Ambiental: a formação do sujeito ecológico. 4⿳ạ ed., São Paulo: Cortez, 2008.

[5] Cunha, M. M. S. A temática ambiental na Educação Científica segundo as Políticas Curriculares Oficiais Brasileiras. Linhas Críticas, Brasília, v. 13, n. 25, p.219-234, jul./dez. 2007.

[6] Guimarães, M. Educação Ambiental crítica. In: Brasil. Ministério do Meio Ambiente / Secretaria Executiva / Diretoria de Educação Ambiental (Org.). Identidades da educação ambiental brasileira. Brasília: Ministério do Meio Ambiente, 2004. p. 25-35.

[7] Mauad, A. M. Na mira do olhar: um exercício de análise da fotografia nas revistas ilustradas cariocas, na primeira metade do século XX. Anais do Museu Paulista, São Paulo, n.1, v.13, p.133-174, jan./jun. 2005. 
[8] Raynaut, C. Meio ambiente e desenvolvimento: construindo um novo campo do saber a partir da perspectiva interdisciplinar. Desenvolvimento e meio ambiente, Curitiba, v.10, p.21-32, jul./dez. 2004.

[9] Reigota, M. Meio ambiente e representação social. 7̣ ed. São Paulo: Cortez Editora, 2007. 


\title{
Capítulo 7
}

Os resultados da avaliação diagnóstica em língua portuguesa e matemática para os alunos das primeiras séries do ensino médio da rede pública Estadual do Ceará: Um instrumento de gestão que orienta a formação e o planejamento docente

\author{
Luciano Nery Ferreira Filho
}

Gezenira Rodrigues da Silva

Ana Paula Pequeno Matos

José Alves Ferreira Neto

Resumo: A Secretaria da Educação Básica do Estado do Ceará - SEDUC/CE iniciou no ano de 2017 uma ação sistêmica de avaliação diagnóstica de todos os alunos regularmente matriculados no ensino médio dessa rede de ensino. Essa ação objetiva traçar um panorama que oriente professores e gestores na elaboração de ações pedagógicas com vistas à melhoria do processo de ensino e aprendizagem. Entendese que uma avaliação com características diagnósticas e formativas possa traçar um desenho que oriente de forma mais eficaz as ações para o saneamento das deficiências cognitivas encontradas contribuindo dessa forma para a determinação e elaboração de estratégias metodológicas com foco no sucesso acadêmico e criando, a nível de rede, um instrumento fundamental para basear políticas de formação continuada de professores. Essa avaliação diagnóstica foi aplicada em dois momentos do ano letivo: ao início desse, como avaliação de entrada, e no início do segundo semestre letivo, como avaliação de processo. No primeiro momento a avaliação mensura, a partir das habilidades que historicamente se mostraram no Sistema Permanente de Avaliação da Educação do Ceará - SPAECE como mais frágeis, o grau de desenvolvimento que os estudantes deveriam ter desenvolvidos na série anterior à avaliada, e a partir disso orienta ações pedagógicas e gerenciais de superação dessas fragilidades. No segundo momento, a avaliação, utilizando-se dos mesmo descritores do primeiro momento, objetiva avaliar o grau de eficácia das ações planejadas a partir do que foi detectado no primeiro momento, contribuindo para a continuidade ou reformulação dessas ações. Essas avaliações são aplicados preferencialmente de forma on line, a partir de sistema informatizado próprio da secretaria, ou, naquelas escolas onde há qualquer impedimento à essa forma de aplicação, ela acontece impressa e posteriormente os resultados são inseridos pela própria escola no mesmo sistema operacional. Isso permite que os resultados e relatórios sejam gerados em curto prazo, promovendo, assim, a construção do desenho do desenvolvimento cognitivo dos alunos das $1^{1^{\mathrm{a}}}, 2^{\mathrm{a}}$ e $3^{\mathrm{a}}$ séries do ensino médio. 0 artigo apresentado estudou a aplicação e os resultados dessa avaliação na contribuição para o sucesso acadêmico dos alunos das $1^{\underline{a}}$ séries do ensino médio dessa rede mostrando sai contribuição para a elaboração de estratégias de intervenção. Para isso implicou no acompanhamento dos resultados da primeira e da segunda etapa da avaliação. Além disso, objetiva também associar essa ação avaliativa de rede à construção histórica de uma avaliação com caráter diagnóstico em contraponto a uma avaliação simplesmente verificatória sendo fundamental para entender a sua função democratizadora do ensino e promovente da equidade dentro da educação, características essenciais na busca pela integração social e formação humana emancipatória construtoras de uma sociedade mais justa e igualitária. 


\section{INTRODUÇÃO}

O planejamento de ações pedagógicas, com vistas à melhoria do processo de ensino e aprendizagem e ao sucesso acadêmico dos alunos, é uma ação complexa e essencial na rotina da regência de professores de qualquer modalidade ou etapa de ensino e de gestores educacionais, sejam estes das redes de educação pública ou privada.

Sendo assim, torna-se essencial a criação de mecanismos capazes de traçar um panorama inicial que identifique, de forma clara, o grau de desenvolvimento das competências e habilidades dos alunos ao início de cada série. Para Souza e Teodora (2015) este cenário propicia ao professor um conhecimento acerca da realidade cognitiva de seus educandos e possibilita, a partir disso, tomadas de decisão que sejam capazes de sanar as deficiências encontradas e fortalecer o processo de consolidação do conhecimento adquirido.

A avaliação de caráter diagnóstico é um mecanismo que, se bem estruturado, pode suprir essa necessidade de apropriação inicial e orientar professores e gestores no planejamento de suas intervenções pedagógicas e políticas de rede. Para Hadji (2001), a importância deste modelo diagnóstico ou prognóstico de avaliação está em sua função primordial que é a possibilidade de se construir um desenho capaz de servir como base para subsidiar o estabelecimento de metas a serem cumpridas, e constituir elemento de apoio à elaboração de planos de ação capazes de contribuir positivamente para o processo de construção e aquisição de conhecimento. Segundo o autor, a avaliação prognóstica e com caráter formativo "precede a ação de formação. (...) tem a função de permitir um ajuste recíproco aprendiz/programa de estudos" (Hadji, 2001, p. 19).

Infere-se, portanto, que essa ação, a nível de rede, constitui-se importante política de democratização da aprendizagem. Segundo Lerche (2007) é fundamental que essas políticas sejam voltadas para a principal função da escola, o ensinar e o aprender. A autora defende que "é importante insistir que as políticas e a gestão da educação básica necessitam encontrar seu foco na essência da tarefa educativa bem ensinar e bem aprender" (Lerche, 2007, p. 67).

Portanto, utilizar os resultados da avaliação com caráter diagnóstico como panorama inicial para as tomadas de decisão, sejam elas no que se refere à determinação de conteúdos e metodologias mais apropriadas ou à necessidade de políticas de formação pedagógica específicas, torna-se essencial para a construção de um modelo equânime de ensino.

A rede pública estadual de ensino do Ceará propôs, no ano de 2017, a construção e aplicação de um modelo de avaliação diagnóstica de entrada e de processo, a fim de amparar os trabalhos dos professores, coordenadores pedagógicos e superintendentes educacionais dessa rede de ensino. Afonso (2000) argumenta que uma avaliação com esses objetivos torna-se instrumento essencial para a gestão, propiciando a vários níveis de atores educacionais alunos, professores, gestores de escola e de rede a ressignificação de sua prática e a proposição de modelos de ação capazes de superar as dificuldades encontradas.

Essa avaliação com caráter diagnóstico é aplicada a todos os alunos das 1aㅡ $2^{\underline{a}}$ e $3^{\underline{a}}$ séries do ensino médio da rede pública estadual, nas disciplinas de Língua Portuguesa e Matemática em dois momentos do ano letivo ao início deste, como avaliação de entrada, objetivando mensurar o grau de desenvolvimento cognitivo que esses educandos possuem ao chegar na série avaliada e orientar a formulação de ações pedagógicas de correção das dificuldades encontradas; e uma outra, como avaliação de processo, no início da segunda metade do ano letivo, para avaliar o grau de eficácia dessas ações no saneamento das dificuldades encontradas e assim orientar sua continuidade ou sua reformulação.

Os resultados obtidos, a partir da avaliação supracitada, são disponibilizados inclusive ao aluno que a realizou, proporcionando meios de autoconhecimento e auto avaliação, os quais se constituem como instrumentos fundamentais para a superação de suas dificuldades cognitivas. Isso conduz a um modelo mais interativo e democrático da prática pedagógica fazendo com que "os seus resultados e planejamentos de ações sejam participativos, entre alunos e professores, e que todos possam ser corresponsáveis no planejamento de ações de superação das dificuldades encontradas." (Luckesi, 2011, p. 118).

Explicita-se, a partir do exposto, os objetivos geral e específicos desse artigo: 


\section{OBJETIVO GERAL}

- Analisar a importância e os impactos da avaliação com caráter diagnóstico para o processo educativo, a partir da experiência de elaboração, aplicação e dos resultados da avaliação diagnóstica implementada pela rede pública de ensino estadual do Ceará.

\subsection{OBJETIVOS ESPECÍFICOS}

- Entender historicamente a construção da proposição de um modelo de avaliação diagnóstica e formativa como substitutiva aos exames verificatórios, de caráter autoritário e classificatório;

- Discutir a importância da avaliação diagnóstica, e sua função formativa, como subsídio para elaboração de ações gerenciais e pedagógicas capazes de influenciar positivamente a melhoria do processo educativo;

- Investigar os resultados da utilização de uma avaliação com caráter diagnóstico, a partir da experiência implantada na rede pública de ensino estadual do Ceará.

\section{METODOLOGIA}

Para fins de composição teórico-conceitual, neste artigo, entende-se o estudo da avaliação com finalidade diagnóstica como um instrumento de construção histórica e fundamentação social, uma vez que possibilita a mudança de preceitos arraigados à prática pedagógica, e possibilita, desde a sua composição, até à conduta adotada diante dos resultados apresentados, uma reflexão acerca do processo avaliativo e de como ele contribui para o processo pedagógico de ensino e aprendizagem em sua totalidade. 0 estudo de um modelo proposto de avaliação que preze pelos preceitos descritos é importante tanto para a compreensão dos fatores que levaram a essa ação, bem como para subsidiar melhorias e ressignificações desse modelo.

A partir disso, desenvolveu-se um método de pesquisa baseado em três momentos:

a) Estudo histórico brasileiro dos modelos de avaliação educacional, levando em conta a importância da avaliação e sua significação para a construção do homem como ser social, com foco nas concepções teóricas que, contrariando os modelos clássicos de exames e provas que caracterizam a pedagogia tradicional, contribuem para a elaboração de um modelo avaliativo capaz de superar o autoritarismo clássico;

b) Estudo da proposição de um modelo avaliativo mais democrático de identificação e intervenção das dificuldades cognitivas apresentadas pelos alunos, contribuindo para a construção de saberes, para a equidade, para a inserção social e para a emancipação humana;

c) Pesquisa de campo objetivando a descrição e análise qualitativa e quantitativa dos resultados obtidos a partir de um modelo de avaliação diagnóstica implantado pela rede de ensino estadual do Ceará, para os alunos das primeiras séries do ensino médio.

Portanto, entende-se que esse artigo possa contribuir para a análise acadêmica dos processos avaliativos como instrumentos de uma pedagogia libertadora e também como meio de refinamento do próprio projeto proposto pela rede de ensino estadual do Ceará.

\section{FUNDAMENTAÇ̃̃O TEÓRICA E RESULTADOS DA PESQUISA DE CAMPO}

\subsection{O ATO DE EXAMINAR: ANÁLISES HISTÓRICAS E CONCEITUAIS}

A construção do processo de avaliação da aprendizagem no Brasil é o resultado de um conjunto de fatores históricos que a conduziram à aplicação de uma metodologia classificatória e punitiva, que buscava apenas a verificação dos conhecimentos adquiridos, sem a preocupação de sanar as dificuldades identificadas.

Segundo Luckesi (2011), essa prática apoiava-se historicamente em três aspectos básicos constituintes da nossa cultura: em primeiro lugar, a nossa formação escolar de caráter jesuítico, dos tempos de colonização, que primavam pela centralidade do saber nos processos de exame e provas finais, classificando os indivíduos como aptos ou não a prosseguir seus estudos, além de objetivarem uma hegemonia católica contra as "heresias protestantes"; em segundo lugar, a pedagogia comeniana, originada de Comênio, que 
primava como centro do processo educativo o professor, e tinha como pressuposto a utilização de provas e exames como forma de manter a disciplina e a atenção dos alunos às aulas proferidas; e em terceiro lugar, a construção cultural brasileira como sociedade burguesa, que através dos seus processos econômicos, sociais e políticos oprime excluídos e opera o medo como forma de controle social, utilizandose para isso, na educação, do instrumento da avaliação, e dos conceitos que fundamentam a pedagogia tradicional.

Essa construção levou ao desenvolvimento de uma cultura amplamente difundida de valorização intensa do resultado final - a nota - em detrimento da aprendizagem e de seus métodos para a consolidação dos conhecimentos. Perrenoud (1999) argumenta que esse sistema clássico de avaliação favorece uma relação utilitarista com o saber, fazendo com que alunos, professores, e comunidade escolar como um todo trabalhem em função da nota.

Luckesi (2011) chama a essa construção de "fetiche" e a conceitua como criação humana que supervaloriza os exames e as provas que levam à nota como objetivo final do processo educativo. Nesse contexto, percebe-se que a relação entre os sujeitos professor e aluno, como relação de construção de saberes, é posta em segundo plano, sendo substituída pela nota como objetivo e objeto dessa relação. Ora, ao se valorizar a nota como produto final do processo educativo, tende-se a inferiorizar a importância do aprendizado e das necessidades individuais e, por conseguinte, a tratar a todos da mesma forma, tornando difícil, segundo Afonso (2000), a identificação das realidades cognitivas individuais e a ação equânime a partir da realidade dos alunos, ação essa essencial ao fazer pedagógico.

Luckesi (2011) diferencia, assim, o ato de examinar do ato de avaliar. 0 primeiro ato sendo identificado como o processo simples de mensuração do conhecimento que, de forma estanque, classifica, em aptos ou não, os educandos de forma definitiva, sem permitir, aos atores envolvidos, a oportunidade de reflexão sobre os resultados obtidos e a modificação da ação, se assim for necessário, que levaram àquele resultado.

Ao se aprofundar no estudo do ato de examinar percebe-se que este possui algumas características que são próprias dele, tais como, o uso de instrumentos inadequados para coletar dados sobre o desempenho, a atenção indevida às necessidades dos educandos e a pressuposição de que educandos possuem menos dificuldades do que existe na realidade (Luckesi, 2011). Além disso, segundo Perrenoud (1999), este ato está associado à criação de "hierarquias de excelência", que promovem a comparação e o classificação de alunos, minimizando a ação educacional, e tornando-a uma ação de legitimação do dominador (professor) sobre o dominado (aluno), pois segundo o autor "a nota é uma mensagem que não diz de início ao aluno o que ele sabe, mas o que pode lhe acontecer se continuar assim até o final do ano" (PERRENOUD, 1999, p. 12).

\subsection{O ATO DE AVALIAR: UM INSTRUMENTO DIAGNÓSTICO E FORMATIVO}

O segundo ato - o de avaliar - para Luckesi (2000), é caracterizado como uma atividade de intervenção para melhoria da realidade e inclusão daqueles que não conseguiram consolidar, ainda, o conhecimento desejado. Segundo o autor, ele envolve a construção de um panorama sobre a realidade do educando e sua reflexão sobre ela, buscando meios de superação. Desta forma, segundo ele, o ato de avaliar é democrático por excelência, pois preocupa-se com a transformação, e fundamenta-se em "um julgamento de valor sobre manifestações relevantes da realidade para uma tomada de decisão" (Luckesi, 2011, p. 90). Assim sendo, identifica realidades diferentes para agir diferentemente sobre elas, tornando mais eficaz e equânime a construção do conhecimento.

Perrenoud (1999) entende que o ato de avaliar tem como objetivo orientar e reorientar o processo de ensino, contribuindo de forma decisiva para sua lapidação e consequentemente com a melhoria da aprendizagem. Além disso, o autor defende que uma avaliação formativa contribui para sanar as dificuldades individuais, pois "não funciona sem regulação individualizada das aprendizagens" (Perrenoud, 1999, p. 149). Segundo ele, a verdadeira ação pedagógico se fundamenta na "intervenção diferenciada", propiciando meios para que todos os sujeitos do processo aprendam.

Ensinar para a perspectiva de sucesso na aquisição de conhecimento e emancipação humana pressupõe entender continuamente em que ponto os estudantes estão e, a partir disso, orientar ações de desenvolvimento cognitivo (Souza; Teodora, 2015). Para as autoras o ato educacional exige que se estabeleça antecipadamente o currículo a ser trabalhado e que tipo de homem se quer formar, e o instrumento avaliativo deve estar a serviço dessa definição. 
Essa concepção também é explorada por Freitas (1995), o autor defende que professores e alunos trazem consigo valores definidores das suas concepções de mundo e que "isso abre um horizonte maior para a própria superação das atuais práticas" (Freitas, 1995, p. 233). O conhecimento pleno do caminho que educadores estão trilhando no desenvolvimento da cognição dos educandos é fator primordial para o sucesso escolar, visto que permite aos primeiros a ressignificação e aprimoramento de sua prática.

No entanto, mais que a mudança no instrumento avaliativo, cabe ao educador "aprender um novo modo de ser e de agir, abrindo mão de conceitos e modos de agir que estão impregnados em nossas crenças conscientes e inconscientes." (Luckesi, 2011, p. 32). Essa inversão paradigmática da avaliação exige que o professor tenha claro os objetivos da sua ação pedagógica e de sua contribuição para a formação humana (Souza; Teodora, 2015). A partir deste viés, o ato de avaliar supera o caráter meramente verificatório e passa a ter o caráter intervencionista, primordial na formação do educando. Para Luckesi (2011), esse rompimento é essencial, pois permite ao professor a mudança de foco apenas no produto entendido aqui como acabado e sem capacidade de mudanças para o processo, que cria um leque de possibilidades de novas práticas pedagógicas mais eficientes.

Nesse contexto, vale ressaltar a reflexão de Freitas (1995) que argumenta sobre o perigo da avaliação ser utilizada como forma científica de consolidação e explicação da exclusão de classes, segundo o autor o conhecimento das diferenças a partir da avaliação que permitiria "uma ação pedagógica diversificada, é elevada à categoria de contradição, na medida em que passa a ser uma 'explicação científica' para a exclusão das camadas populares da escola" (Freitas, 1995, p. 246). A partir disso, torna-se essencial a ressalva de que $o$ ato de avaliar sem a tomada de decisão no sentido de sanar os problemas detectados com vistas à melhoria da aprendizagem pode torna-se perigoso por constituir-se instrumento de reafirmação de exclusão de classes. A ação avaliativa com função diagnóstica deverá estar a serviço da superação dessa exclusão, constituindo instrumento importante de inserção e transformação social. Tal ação objetiva superar o preceito autoritário do exame clássico, levando a um modelo mais democrático, pois "deverá ser o instrumento dialético do avanço, terá de ser o instrumento de identificação de novos rumos" (Luckesi, 2011, p. 91).

\subsection{CARACTERÍSTICAS DA AVALIAÇÃO DIAGNÓSTICA CEARENSE}

A rede pública de ensino estadual do Ceará, iniciou, em 2017, um programa sistêmico de avaliação diagnóstica para todas as suas séries do ensino médio nas disciplinas de Língua Portuguesa e Matemática.

Essa ação visa, além da construção de um panorama que indique o nível de conhecimento que os alunos tem ao entrar nas três séries do ensino médio e possibilite aos professores maiores subsídios na formulação dos seus planos de aula, também promovam, a nível de rede, a detecção das necessidades de formação de docentes e de gestores educacionais. De acordo com o projeto norteador dessa avaliação, por meio desta ferramenta

poderão ser avaliadas as competências construídas e as habilidades desenvolvidas até então, de forma que se consiga detectar os problemas de aprendizagem, através dos resultados obtidos. Estas informações subsidiarão a adoção de medidas que superem as dificuldades observadas e que contribuam para a melhoria da qualidade de ensino não só na escola, mas em toda rede estadual. (SEDUC/CE, 2016, p. 7).

Essa avaliação leva em conta os descritores que, historicamente, se mostraram mais frágeis a partir do Sistema Permanente de Avaliação da Educação Básica do Ceará Spaece, que é a avaliação externa própria da rede pública cearense. No projeto base dessa ação é explicitada que foram identificados, para a composição da avaliação diagnóstica das primeiras séries do ensino médio, os cinco descritores ${ }^{13}$ com maiores fragilidades históricas em Língua Portuguesa e Matemática captados na avaliação externa citada e aplicada aos 9o anos do ensino fundamental ${ }^{14}$ e descritos na tabela 1.

\footnotetext{
13 Os descritores avaliados são originados da matriz de referência do Centro de Avaliação da Educação (CAEd), órgão ligado à Universidade Federal de Juiz de Fora (UFJF), que por sua vez, se utilizou da matriz do Sistema de Avaliação da Educação Básica (SAEB) como referência para essa composição.

14 O SPAECE avalia historicamente, de forma censitária, três séries do ensino fundamental, o 2o, o 5o e o 9o ano. No ensino médio o SPAECE possui certa variação, em algumas edições foram avaliadas às três séries, e em outras edições a apenas algumas das séries. Na última edição, de 2016, apenas a 3ª série foi avaliada, e de forma censitária.
} 
Tabela 1 Descritores avaliados na avaliação diagnóstica da 1aa série do ensino médio

\begin{tabular}{|l|l|}
\hline D06 & Distinguir fato de opinião relativa ao fato. \\
\hline D07 & Diferenciar a informação principal das secundárias em um texto. \\
\hline D12 & Identificar semelhanças e/ou diferenças de ideias e opiniões na comparação entre os textos. \\
\hline D17 & Reconhecer o sentido das relações lógico-discursivas marcadas por conjunções, advérbios, etc. \\
\hline D21 & Reconhecer o efeito decorrente do emprego de recursos estilísticos e morfossintáticos. \\
\hline Descritores de Matemática
\end{tabular}
Fonte: Projeto de Avaliação Diagnóstica Seduc/CE, 2016

Para cada um dos descritores citados acima foram construídos e pré-testados três itens com níveis crescentes de dificuldade, compondo assim a avaliação diagnóstica da série inicial do ensino médio. Essa avaliação foi aplicada de forma censitária, de forma on line, em sistema informatizado da própria secretaria, e nas escolas onde houve dificuldade para a aplicação on line, a avaliação pôde ser realizada de forma impressa, e, posteriormente, os resultados foram inseridos no mesmo sistema, gerando relatórios para posterior intervenção.

A apropriação desses resultados é feita de forma generalizada por todos os que compõe a rede pública estadual de ensino, desde o aluno, que tem acesso aos seus resultados individuais, até aos professores e gestores, possibilitando um conjunto de ações com vistas a sanar as dificuldades apresentadas. Essa ação formativa reflete "a forma de uma regulação interativa, isto é, uma observação e uma intervenção em tempo real" (Perrenoud, 1999, p, 101), que objetiva o sucesso acadêmico dos alunos.

\subsection{ALGUNS RESULTADOS DA AVALIAÇÃO DIAGNÓSTICA DA PRIMEIRA SÉRIE}

Alguns dados são importantes de serem analisados comparando a primeira com a segunda aplicação da avaliação diagnóstica em 2017. 0 gráfico 1 mostra a participação dos alunos da primeira série do ensino médio da rede pública discriminando por modalidade de escola e por turno. É importante ressaltar que nessa etapa foram avaliados, na primeira aplicação, um total de 115.761 alunos e na segunda aplicação 111.827 alunos, o que constitui, respectivamente, $85,1 \%$ e $84,2 \%$ do total de alunos matriculados nessa etapa do ensino médio. Apesar de leve decréscimo 0,9 pontos percentuais entre as duas aplicações, o percentual é maior que $80,0 \%$ possibilitando valor estatístico aceitável para posteriores análises.

Gráfico 1 Análise comparativa da participação dos alunos da 1aㅗ série do EM na $1^{\underline{a}}$ e $2^{a}$ aplicações da av. Diagnóstica

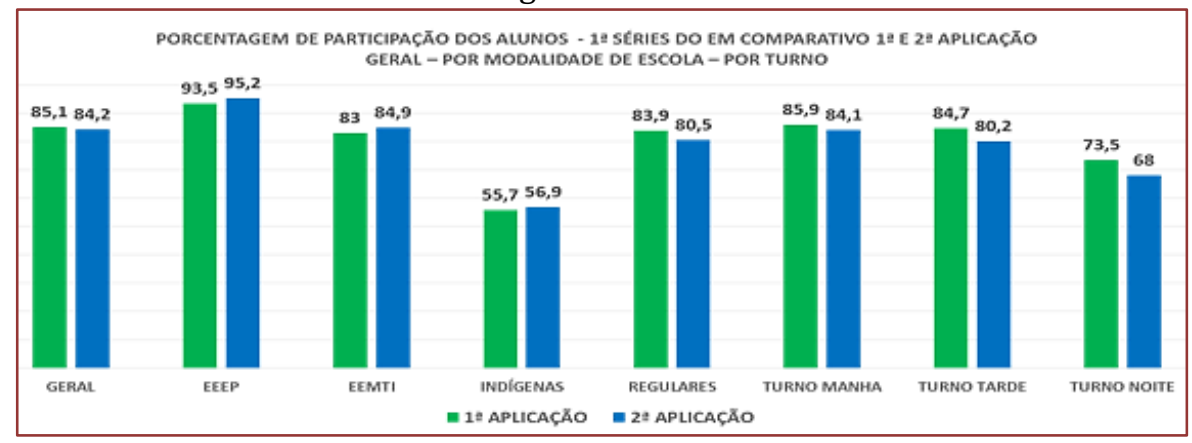


Dentre as modalidades de escolas estaduais, aquelas com maior percentual de alunos avaliados foram as EEEP15 com 93,5\% e 95,2\%, respectivamente, na primeira e segunda aplicações. As EEMTI16, apresentaram aumento de participação entre a primeira (83\%) e a segunda aplicação (84,9\%). Percebe-se um comportamento inverso nas escolas que ofertam turmas de primeira série em meio expediente (escolas regulares), nesse grupo houve decréscimo de participação entre a primeira (83,9\%) e a segunda aplicação (80,5\%). As escolas indígenas do estado, possuem o menor grau de participação, um pouco acima de 50,0\%, no entanto, percebe-se, nessas escolas, um aumento do número de alunos avaliados entre a primeira $(55,7 \%)$ e a segunda aplicação $(56,9 \%)$.

Entre os turnos, observa-se no turno da manhã maior percentual de alunos avaliados em ambas as aplicações, apesar de leve decréscimo, entre a primeira aplicação $(85,9 \%)$ e a segunda $(84,1 \%)$. 0 turno com menor participação foi o noturno, que ainda apresentou decréscimo de alunos avaliados entre a primeira aplicação $(75,5 \%)$ e a segunda (68\%).

Os descritores avaliados e seu percentual de acertos constitui outra análise importante a se fazer a partir dos dados colhidos. 0 gráfico 2 detalha a porcentagem média de acertos entre os três itens componentes de cada descritor de Língua Portuguesa.

Gráfico 2 Análise comparativa (1ํㅗ e $2^{\underline{a}}$ aplicação) do percentual médio de acertos dos itens de Língua Portuguesa por descritor.

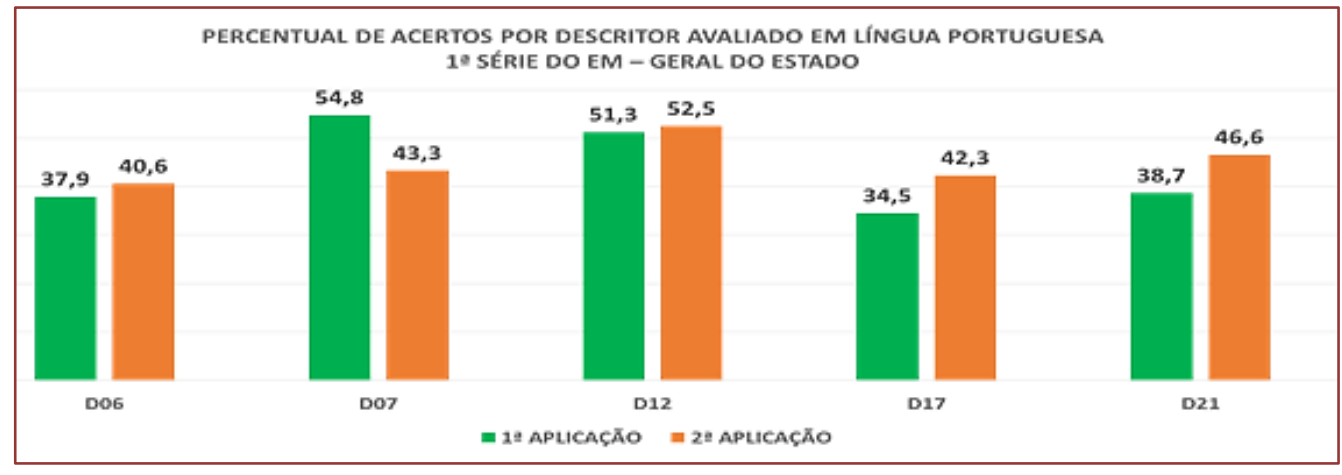

Pela análise do gráfico 2 percebe-se que houve melhoria da quantidade de acertos em quatro dos cinco descritores, quando se compara a primeira aplicação com a segunda. Infere-se, a partir dessa análise, que as ações pedagógicas estratégicas traçadas para se desenvolver essas habilidades nos alunos tiveram impacto positivo. Dentre as ações, aquelas que focaram os descritores D17 e D21 foram as mais bem sucedidos, pois houve aumento de mais de 7,5 pontos percentuais de acertos nos itens referentes a esses descritores entre a primeira e a segunda aplicação. No entanto, o descritor D0717 ainda preocupa, pois apresentou decréscimo de acertos entre a primeira $(54,8 \%)$ e a segunda aplicação $(43,3 \%)$, ou seja, uma diminuição de 11,5 pontos percentuais. Portanto, as ações programadas para consolidação dos conhecimentos referentes ao desenvolvimento das competências referentes a esse descritor precisam ser revistas e aprimoradas.

Da mesma forma o gráfico 3 refere-se a porcentagem média de acertos entre os itens que avaliaram os descritores de matemática.

\footnotetext{
15 EEEP - Escolas Estaduais de Educação Profissional

16 EEMTI - Escolas de Ensino Médio em Tempo Integral

170 descritor D07 refere-se, segundo a tabela 1, a "Diferenciar a informação principal das secundárias em um texto".
} 
Gráfico 3 Análise comparativa (1ํㅗ e 2ª aplicação) do percentual da média de acertos dos itens de Matemática

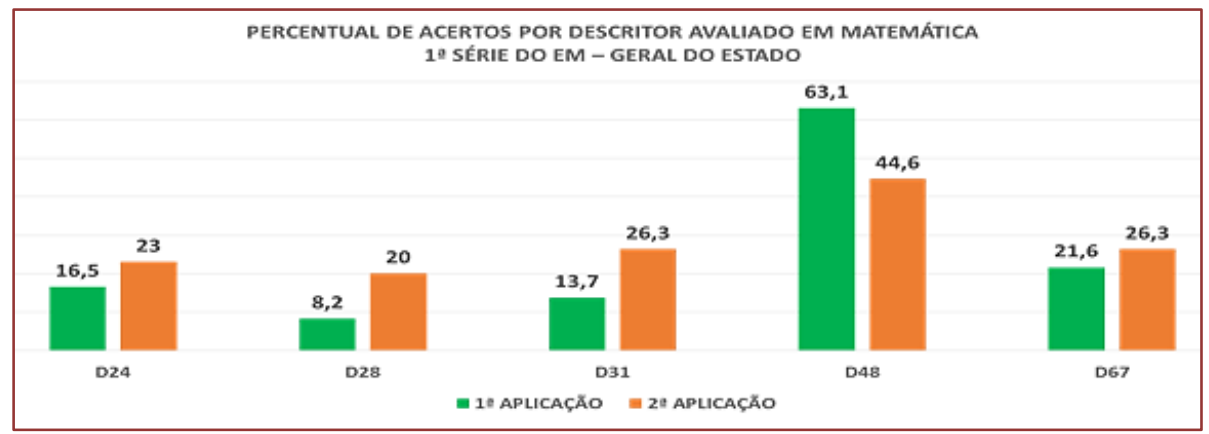

Pela análise do gráfico 3 percebe-se que houve melhoria da quantidade de acertos em quatro dos cinco descritores, quando se compara a primeira aplicação com a segunda. Pela análise, infere-se que as ações pedagógicas estratégicas traçadas para se desenvolver essas habilidades nos alunos tiveram impacto positivo. Dentre as ações, aquelas que focaram os descritores D28 e D31 foram as mais bem sucedidos, pois houve aumento de mais de 11,5 pontos percentuais de acertos nos itens referentes a esses descritores entre a primeira e a segunda aplicação. No entanto, o descritor D48 ${ }^{18}$ ainda preocupa, pois apresentou decréscimo de acertos entre a primeira $(63,1 \%)$ e a segunda aplicação $(44,6 \%)$, ou seja, uma diminuição de 18,5 pontos percentuais. Portanto, as ações programadas para consolidação dos conhecimentos referentes ao desenvolvimento das competências referentes a esse descritor precisam ser revistas e aprimoradas.

\section{ANÁLISES CONCLUSIVAS}

A partir disso, pode-se entender então que a avaliação com função diagnóstica cumpre os pressupostos de uma avaliação formativa, na medida em que promove o conhecimento da realidade para posterior intervenção, contribuindo sobremaneira na promoção da equidade dentro do ambiente escolar. Além disso, uma avaliação diagnóstica promove uma regulação interativa, pois desenvolve uma relação entre professores e alunos, na busca de soluções para a superação das dificuldades encontradas, possibilitando uma avalanche crescente de conhecimentos que permitem, cada vez mais, tornar claro as causas da não aprendizagem e, consequentemente, os modelos de ações necessárias para intervenções individualizadas.

Deste modo, uma avaliação diagnóstica é parte de um conjunto de ações e de estratégias metodológicas que "permite que todos (docente, discente e sistema de ensino) possam se auto compreender, diagnosticando deficiências e capacidades e direcionando ações corretivas" (Ribeiro; Figueiredo, 2010, p. 6). Essa análise possibilita inferir que o processo avaliativo permite a tomada de decisão que ultrapassa a ação pedagógica dentro da escola e chega até a tomada de decisão a nível de rede de ensino, orientando, inclusive, o planejamento de ações para formações continuadas de professores e gestores com foco em metodologias, práticas e conteúdos que favoreçam o saneamento das dificuldades apontadas.

Sendo assim, a avaliação ganha contornos de importante instrumento de gestão, contribuindo para orientar passos concretos e essenciais a serem dados no caminho da construção de uma escola democrática e equânime que possibilite a seus alunos e professores a superação do autoritarismo e promoção da construção do conhecimento como objetivo primordial da educação.

\footnotetext{
${ }^{18}$ O descritor D48 refere-se, segundo a tabela 1, a "Identificar e classificar figuras planas: quadrado, triângulo e círculo, destacando algumas de suas características (número de lados e tipo de ângulos)".
} 


\section{REFERÊNCIAS}

[1] Afonso, Almerindo Janela. Avaliação Educacional: regulação e emancipação. 2a ed., São Paulo/SP: Cortez Editora, 2000.

[2] Freitas, Luis Carlos de. Crítica da organização do trabalho pedagógico e da didática. Campinas/SP: Papirus Editora, 1995.

[3] Hadji, Charles. Avaliação desmistificada. 1a ed., Porto Alegre/RS: Artmed Editora, 2001.

[4] Lerche, Sofia. Politica(s) e gestão da educação básica: revisitando conceitos simples. RBPAE. v.23, n.1, p. 5369, jan/abr. 2007.

[5] Luckesi, Cipriano Carlos. A avaliação da aprendizagem escolar: estudos e proposições. 22ª ed., São Paulo/SP: Cortez Editora, 2011.

[6] Perrenoud, Philippe. Avaliação: da excelência à regulação das aprendizagens: entre duas lógicas. Porto Alegre/RS: Artmed Editora, 1999.

[7] Ribeiro, Ledacy Paiva; Figueiredo, Jorge Alberto. Avaliação diagnóstica: uma breve reflexão. Curitiba/PR: Seduc/Paraná, 2010.

[8] Seduc/CE, Secretaria da Educação Básica do Estado do Ceará. Projeto de avaliação diagnóstica para o ensino médio. Fortaleza/CE, 2016.

[9] Souza, Clarilza Prado de; Teodora, Romilda. Avaliação Formadora. In: Torres, Patrícia Lupion (Org.). Metodologias para a construção do conhecimento: da concepção à prática. 1aa ed., Paraná: Senar Editora, Curitiba/PR, 2015. (p. 325-369). 


\section{Capítulo 8}

A ação do reforço escolar por meio da ludicidade: Abordagem metodológica no ambiente do subprojeto matemática PIBID

\section{Rodiney Marcelo Braga dos Santos}

Maria de Fátima Pereira da Silva

José Jorge de Souza Silva

Fabrícia dos Santos Pereira

Felipe Erick Moura da Silva

Sabrina Karina da Silva Sousa

José Rufino Rodrigues Filho

Matheus de Oliveira Silva

Resumo: Historicamente, o ensino da matemática esteve condicionado à metodologia tradicional baseada na exposição minimamente dialogada e por meio da (re)produção de objetos de conhecimento descontextualizados. Todavia, com a urgência em ressignificar a tríade ensino, aprendizagem e avaliação, enfatizamos a apropriação das estratégias de ensino através das metodologias ativas no cotidiano escolar. Este estudo se justifica pelo baixo índice de aprendizagem dos alunos matriculados nos ciclos III e IV da modalidade de Educação de Jovens e Adultos (EJA), na E.M.E.I.E.F Crispim Coêlho, Cajazeiras, Paraíba. 0 objetivo deste estudo consiste em realizar um diagnóstico preliminar com o referido público-alvo, bem como aplicar uma proposta metodológica balizada na apropriação das metodologias ativas de ensino e abordagem do letramento matemático, na perspectiva da ludicidade, e desenvolvida no âmbito do subprojeto da área da matemática do Programa Institucional de Bolsa de Iniciação à Docência (Pibid) pelo Instituto Federal de Educação, Ciência e Tecnologia da Paraíba, campus Cajazeiras. A ordenação e apropriação das tendências metodológicas já supracitadas, nas aulas de matemática, é um campo complexo no que concerne seu ensino. Foi possível refletir sobre de que forma essas atividades assistiram e ampliaram os objetivos de ensino, pois a essência da prática pedagógica por meio de projetos acontece a partir de um planejamento comprometido com um fazer matemática dirigido a demanda do públicoalvo em questão.

Palavras-chave: Matemática; ludicidade; jogos educativos; Pibid. 


\section{INTRODUÇÃO}

Historicamente, o ensino da matemática esteve condicionado à metodologia tradicional baseada na exposição minimamente dialogada e por meio da (re)produção de objetos de conhecimento descontextualizados. Todavia, com a urgência em ressignificar a tríade ensino, aprendizagem e avaliação, enfatizamos a apropriação das estratégias de ensino através das metodologias ativas no cotidiano escolar. Destarte, o professor deve assumir o papel de mediador e o aluno de protagonista do processo, sendo o ensino estimulado por percursos metodológicos dinâmicos e inovadores e que a aprendizagem seja concebida de forma significativa.

Este estudo se justifica pelo baixo índice de aprendizagem dos alunos matriculados nos ciclos III e IV da modalidade de Educação de Jovens e Adultos (EJA), na E.M.E.I.E.F Crispim Coêlho, Cajazeiras, Paraíba. Nosso objetivo consiste em realizar um diagnóstico preliminar com o referido público-alvo, bem como aplicar uma proposta metodológica balizada na apropriação das metodologias ativas de ensino e abordagem do letramento matemático, na perspectiva da ludicidade, e desenvolvida no âmbito do subprojeto da área da matemática do Programa Institucional de Bolsa de Iniciação à Docência (Pibid) pelo Instituto Federal de Educação, Ciência e Tecnologia da Paraíba, campus Cajazeiras. O Pibid é uma ação da Política Nacional de Formação de Professores do Ministério da Educação que visa proporcionar aos discentes, na primeira metade do curso de licenciatura, uma aproximação e estreitamento da teoria com a prática no ambiente cotidiano do processo educativo das escolas públicas da educação básica e com o contexto em que elas estão inseridas.

0 uso das metodologias ativas de ensino é tomada de partida para o avanço de ambientes de aprendizagem mais elaborados (MORÁN, 2015). 0 autor sinaliza que a aprendizagem significativa deve ser promovida por meio da problematização. Os Parâmetros Curriculares Nacionais abordam alguns percursos metodológicos para fazer matemática na sala de aula. À guisa de exemplificação, destacamos a ludicidade e o recurso aos jogos educativos que podem fornecer os contextos dos problemas, bem como as ferramentas para a construção das estratégias de resolução (BRASIL, 1998). Os jogos são atrativos para quem exercita essa prática e instigantes, gerando recompensa, autonomia, criatividade, competição e engajamento coletivo (GRANDO, 2000).

No que concerne à prática do letramento, se faz necessária a construção de significados e aplicabilidade no cotidiano do aprendiz. A primazia pelo uso do termo letramento matemático é uma concepção universal, que propõe reflexão e ação, bem como suas interconexões com o conceito de alfabetização utilizado na língua (GONÇALVES, 2010). 0 letramento transcende a alfabetização, expandindo o conhecimento dela adquirida para além da sala de aula. Quando se é letrado em matemática, esse conhecimento passa a fazer parte do cotidiano por meio da oralidade e da escrita.

\section{FUNDAMENTAÇÃO TEÓRICA}

Em todo seu processo histórico, os objetos de conhecimento da matemática escolar são vistos no ambiente formativo como complexos. Na realidade contemporânea, vemos que essa área do conhecimento no espaço escolar é permeada pela condição de difícil acesso, compreensão e apropriação por parte do sujeito aluno. Desse modo, o processo de ensino e aprendizagem se resume no ato de decorar conceitos e fórmulas, sem de fato internalizar sua essência e significado para vida. Consequentemente, o que é explicado não é questionado, pois os alunos consideram a matemática como uma ciência concreta e de absolutas certezas, repleta de conceitos e teoremas não indagáveis criados e descobertos por grandes gênios, dotados de uma inteligência superior (D'AMBROSIO, 1989).

Nesse contexto, a EJA está inserida em um cenário mais delicado em virtude da inúmeras dificuldades provenientes desde o preconceito da sociedade com seu público-alvo que não conseguiu ou pôde concluir o ensino regular na idade apropriada até a grande carga de responsabilidade que a vida adulta acarreta, $o$ que tem influenciado diretamente nos altos índices de evasão escolar dessa modalidade. Para Lopes e Sousa (2005, p. 2) "É papel do professor, especialmente do professor que atua na EJA, compreender melhor o aluno e sua realidade diária. Enfim, é acreditar nas possibilidades do ser humano, buscando seu crescimento pessoal e profissional". Destarte, a abordagem do letramento matemático se impõe como uma necessidade no processo de ensino e aprendizagem. A Matriz do Programa Internacional de Avaliação de Estudantes (Pisa) ${ }^{19}$ define o letramento matemático como:

19 O Programa Internacional de Avaliação de Alunos (Pisa) é uma avaliação internacional que mede o nível educacional de jovens de 15 anos por meio de provas de Leitura, Matemática e Ciências. 
a capacidade individual de formular, empregar, e interpretar a matemática em uma variedade de contextos. Isso inclui raciocinar matematicamente e utilizar conceitos, procedimentos, fatos e ferramentas matemáticas para descrever, explicar e predizer fenômenos. Isso auxilia os indivíduos a reconhecer o papel que a matemática exerce no mundo e para que cidadãos construtivos, engajados e reflexivos possam fazer julgamentos bem fundamentados e tomar as decisões necessárias (BRASIL, 2013, p. 1).

À medida que se fala de letramento matemático, deve-se considerar as possíveis dificuldades de aprendizagem que resultam em um baixo nível de proficiência dos alunos, seja por fatores internos (cognitivos) ou externos (metodologia dos professores, pedagógico, entre outros). Considerando os fatores externos, ressurge então a pauta do reforço escolar como uma ação necessária para ampliar o ambiente de ensino. Para Alves (2018), essa prática tem o intuito de superar as disparidades de perspicácia e assimilação dos alunos referentes aos conteúdos abordados em sala de aula.

Nesse contexto, sinalizamos a utilização das metodologias ativas de ensino ao invés de aulas expositivas, que se mostram muitas vezes insuficientes, estas balizadas na aprendizagem centrada no aluno, assim, possibilitando o acesso à aquisição do conhecimento de forma mais robusta. Ademais, que o professor deve atuar como mediador do conhecimento, intervindo quando se faz necessário e não mais como controlador de todo o processo de ensino, como acontece nas aulas expositivas e o aluno como o centro, ou seja, (co)responsável pelo desenvolvimento do seu aprendizado. Para tanto, pontuamos o caráter dinâmico da ludicidade por meio de jogos educativos. Segundo Alves (2018, p. 31) "O professor tem que trabalhar com atividades lúdicas fazendo com que os alunos consigam pensem de forma diferenciada. Os professores devem traças um perfil dos alunos com defasagem na aprendizagem". Segundo Grando (2000, p. 01):

As atividades lúdicas são inerentes ao ser humano. Cada grupo étnico apresenta sua forma particular de ludicidade, sendo que o jogo se apresenta como um objeto cultural. Por isso, encontramos uma variedade infinita de jogos, nas diferentes culturas e em qualquer momento histórico. [...] A necessidade do Homem em desenvolver as atividades lúdicas, ou seja, atividades cujo fim seja o prazer que a própria atividade pode oferecer, determina a criação de diferentes jogos e brincadeiras. Esta necessidade não é minimizada ou modificada em função da idade do indivíduo. Exercer as atividades lúdicas representa uma necessidade para as pessoas em qualquer momento de suas vidas. Se observarmos nossas atividades diárias, identificamos várias atividades lúdicas sendo realizadas.

É necessário que antes de escolher um material lúdico, o professor tenha definido sua concepção didático e pedagógica para o tratamento da matemática de modo que potencialize sua construção de forma significativa, ou seja, os materiais lúdicos devem ser considerados como um complemento das aulas, pois por si só não tem validade. A mera inclusão de jogos nas aulas de matemática não assegura uma melhor aprendizagem dos discentes (FIORENTINI; MIORIM, 1990). Outrossim, é essencial conhecer o públicoalvo, para que assim ocorra uma aprendizagem eficaz, de tal modo que o indivíduo possa protagonizar seu entorno atribuindo significado ao conhecimento construído.

Dessa forma, fica clara a importância dos jogos educativos e seu caráter formativo durante a vida acadêmica dos alunos, pois as situações de aprendizagem que eles possibilitam desde a tomada de decisões até as relações entre sujeitos envolvidos podem criar condições para a efetivação do conhecimento analítico e reflexivo, ou seja, podem tornar a aquisição do conhecimento mais agradável e eficaz, assim potencializando o letramento matemático.

\section{PERCURSO METODOLÓGICO}

Inicialmente foi feita a imersão dos bolsistas na escola campo, assim ocorrendo o primeiro contato formal com os diversos atores (núcleo gestor, professores, funcionários e alunos) da referida unidade escolar. Então se deu o momento de ambientação, por meio do estudo do Projeto Político Pedagógico para o (re)conhecimento da identidade da escola, sendo apresentadas as primeiras impressões sobre o ambiente de trabalho, bem como os possíveis desafios e perspectivas. 0 primeiro contato com a comunidade escolar se deu por meio da aplicação de uma atividade lúdica na Feira de Ciência realizada pela escola no final do semestre do último ano letivo. Foi utilizado o recurso do 'código morse' para o estudo dos números e suas operações aritméticas fundamentais. 
Outrossim, os bolsistas participaram da regência da professora supervisora desde a observação até a (co)participação. A atividade de ensino consistia na realização de uma gincana por meio da resolução de problemas e utilização de um objeto de aprendizagem para fixação do conteúdo abordado. Neste momento, os bolsistas diagnosticaram, mesmo de forma pontual, o conhecimento prévio dos alunos acerca do tópico 'equação do primeiro grau', bem como puderam estreitar uma relação recíproca com os estudantes.

Com o início do processo de ambientação dos bolsistas na escola campo, foi realizado o planejamento para elaboração da avaliação diagnóstica. Os alunos elaboraram questões contextualizadas de acordo com os eixos temáticos descritos na Base Nacional Comum Curricular (BNCC). Os pibidianos realizaram um estudo sobre o componente curricular matemática, este que posteriormente foi centro de um debate entre o grupo atuante na escola campo, juntamente com a professora supervisora. Foram discutidos pontos, como: competências gerais, unidades temáticas, objetos do conhecimento e habilidades (BRASIL, 2017). Seguindo essa etapa de ambientação com a BNCC, os bolsistas foram encarregados de, individualmente, elaborarem um plano de aula. Em seguida, houve o estudo dos descritores de matemática para o ensino fundamental II.

Outrossim, ao considerar a escrita acadêmica como ação do subprojeto foi proposto um espaço de aprendizagem para o estudo das metodologias científicas. A professora supervisora buscou viabilizar o processo de familiarização e imersão dos bolsistas nesse campo. Primeiramente, foi realizado um grupo de estudo sobre redação científica, formatação e elaboração de artigos a partir da leitura e análise de textos científicos. Em seguida, sob sua supervisão, os bolsistas deram início à elaboração de resumos simples baseados nos artigos apreciados.

Concluída a fase de estudos sobre a BNCC, os descritores de matemática para o ensino fundamental e as orientações para a produção de artigo científico, foi realizado e executado o planejamento de uma atividade de entrada (diagnóstica) com os alunos contemplados pelo subprojeto. Vale ressaltar que esta etapa teve como tomada de partida os estudos antepostos. Após a elaboração de 10 questões objetivas, para cada ciclo (III e IV), o instrumental foi aplicado. Por consequência, a ordenação e análise dos dados.

A avaliação diagnóstica foi corrigida e os dados foram tabulados por meio da elaboração de gráficos no software Excel. Com a tabulação dos dados obtidos, foi possível constatar as unidades temáticas de melhor e pior desempenho, dando embasamento para a elaboração do instrumental metodológico, ou seja, a avaliação diagnóstica apontou os eixos temáticos de maior urgência para a atuação do projeto.

Em posse desses dados, o grupo de 09 (nove) bolsistas foi orientado pela supervisora a ser subdividido em subgrupos para o estudo dos elementos que compreendem a elaboração de uma estratégia metodológica, bem como foi feita uma breve revisão bibliográfica acerca das metodologias ativas de ensino e a abordagem do letramento matemático, sendo definidos alguns jogos para serem trabalhados no subprojeto: bingo das frações, jogo com o Tangram, jogos com palitos, dinâmico do guia financeiro e jogo com baralhos.

\section{ATIVIDADE DE ENTRADA (DIAGNÓSTICA) APLICADA AOS ALUNOS DOS CICLOS III E IV DA EJA}

Esta seção aborda a avaliação diagnóstica realizada na escola campo Crispim Coêlho para identificar o nível de conhecimento dos alunos, suas competências e habilidades. As informações do nível de proficiência dos alunos, através do instrumento avaliativo, apontaram os eixos temáticos referente ao componente curricular matemática de maior déficit de aprendizagem. Desse modo, foi elaborado um instrumental metodológico com jogos matemáticos com o objetivo de motivá-los a desenvolver novas competências e habilidades.

Após a aplicação da avaliação diagnóstica, prosseguimos com a correção, obtendo-se os resultados expressivos sobre o nível de aprendizagem das turmas da EJA investigadas.

A avaliação diagnóstica foi composta por 20 questões de múltipla escolha com 04 (quatro) alternativa cada, sendo 10 para cada ciclo da EJA. As questões foram descentralizadas nos eixos estruturantes: números (seis questões), geometria (quatro questões), grandezas e medidas (duas questões), estatística e probabilidade (três questões) e álgebra (cinco questões).

Embora algumas questões envolvessem mais de uma unidade temática foi considerada a de maior prevalência no contexto e estrutura da questão. Foram selecionadas 05 (cinco) questões de cada ciclo, considerando as de bom nível de interpretação e contextualização para serem analisadas as habilidades adquiridas pelos alunos investigados a partir da quantificação do número de acertos e erros, de acordo 
com o nível de interpretação exigido por cada questão. As outras questões que exigiam pouca interpretação foram descartadas dessa análise.

Quanto ao ciclo III, a primeira questão versou sobre a unidade temática 'grandezas e medidas', sendo abordado a habilidade EF07MA2920 (resolver e elaborar problemas que envolvam medidas de grandezas inseridos em contextos oriundos de situações cotidianas ou de outras áreas do conhecimento, reconhecendo que toda medida empírica é aproximada). A questão que demandava um bom nível de interpretação, totalizou 14 acertos e 04 (quatro) erros, superando a média.

A segunda questão compreendeu uma das 05 (cinco) questões que abordavam a unidade temática 'números', sendo utilizando o objeto de conhecimento 'números racionais'. Procuramos desenvolver a habilidade EF06MA07 (compreender, comparar e ordenar frações associadas às ideias de partes de inteiros e resultado de divisão, identificando frações equivalentes). A questão que exigia conceitos básicos sobre representações de números racionais obteve um bom resultado com um total de 11 acertos e 3 (três) erros.

Uma das duas questões acerca da unidade temática 'álgebra' buscou trabalhar a habilidade EF06MA15 (resolver e elaborar problemas que envolvam a partilha de uma quantidade em duas partes desiguais, envolvendo relações aditivas e multiplicativas, bem como a razão entre as partes e entre uma das partes e o todo). Apresentando um desempenho razoável, a turma investigada obteve 09 (nove) acertos e 05 (cinco) erros.

Apenas a nona questão abordou sobre 'probabilidade e estatística'. 0 conteúdo contemplado foi a média aritmética e a habilidade EF07MA35 (compreender, em contextos significativos, o significado de média estatística como indicador da tendência de uma pesquisa, calcular seu valor e relacioná-lo, intuitivamente, com a amplitude do conjunto de dados) que apresentou um bom resultado, onde 10 alunos acertaram e 04 (quatro) erraram.

A décima questão abordou sobre a unidade temática 'geometria' e a habilidade EF06MA19 (identificar características dos triângulos e classificá-los em relação às medidas dos lados e dos ângulos). Com a obtenção de 0 (zero) acertos e 14 erros, identificamos uma defasagem gritante quanto a essa unidade temática, o que nos incita a trabalhá-la com mais urgência. A Figura 1 ilustra a tabulação das questões da avaliação diagnóstica do ciclo III.

Figura 1: Avaliação diagnóstica do ciclo III

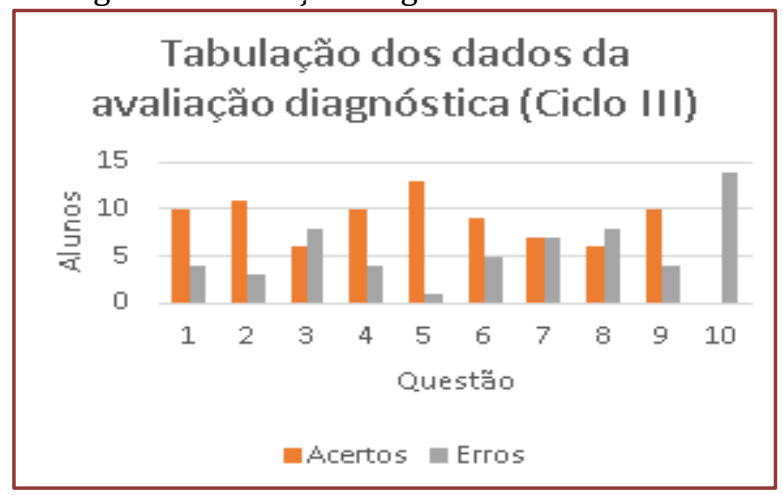

Quanto ao ciclo IV, a primeira questão abordou a unidade temática 'álgebra', sendo contemplada a habilidade EF06MA15 (resolver e elaborar problemas que envolvam a partilha de uma quantidade em duas partes desiguais, envolvendo relações aditivas e multiplicativas, bem como a razão entre as partes e entre uma das partes e o todo). Esta questão trazia uma situação problema onde o aluno deveria aplicar noções básicas de divisão. A turma investigada apresentou um total de 07 (sete) acertos e apenas 01 (um) erro.

A segunda questão trouxe a unidade temática 'probabilidade e estatística', sendo abordada a habilidade EF01MA21 (ler dados expressos em tabelas e em gráficos de colunas simples). A questão fornecia alguns dados referentes as notas que João obteve em três disciplinas e requeria a nota mínima que ele deveria obter na quarta prova para ser aprovado. A turma obteve um total de 05 (cinco) acertos e 03 (três) erros.

${ }^{20}$ Habilidades extraídas da BNCC. 
A terceira questão compreendia a unidade temática 'grandezas e medidas', sendo abordada a habilidade EF08MA19 (resolver e elaborar problemas que envolvam medidas de área de figuras geométricas, utilizando expressões de cálculo de área, quadriláteros, triângulos e círculos, em situações como determinar medida de terrenos). A questão requisitava a noção de área das figuras planas e transformações de unidades de medida. Foi considera uma das mais complicadas pelos bolsistas. No entanto, a referida turma demonstrou um bom domínio da habilidade, pois totalizou 06 (seis) acertos e apenas 02 (dois) erros, logo os alunos obtiveram um ótimo desempenho.

A quarta questão abordou a unidade temática 'geometria', requerendo do aluno as habilidades EF07MA30 (resolver e elaborar problemas de cálculo de medida do volume de blocos retangulares, envolvendo as unidades usuais, metro cúbico, decímetro cúbico e centímetro cúbico). A questão era considerada razoável para aquele ciclo, pois contemplava conteúdos de anos anteriores, em específico o volume de um sólido regular. No entanto, a grande maioria não demonstrou domínio adequado do conteúdo, apresentando um total de 06 (seis) erros e apenas 02 (dois) acertos, sendo o maior índice de erros.

A última questão tratou sobre a unidade temática 'números', sendo contemplada a habilidade EF06MA07 (compreender, comparar e ordenar frações associadas às ideias de partes de inteiros e resultado de divisão, identificando frações equivalentes). A pergunta trazia noções de frações e sua representação de um todo. No entanto, também apresentou um alto índice de erros, pois apenas 03 (três) alunos conseguiram marcar a alternativa correta e 05 (cinco) marcaram a alternativa errada. A Figura 2 ilustra a tabulação das questões da avaliação diagnóstica do ciclo IV.

Figura 2: Avaliação diagnóstica do ciclo IV

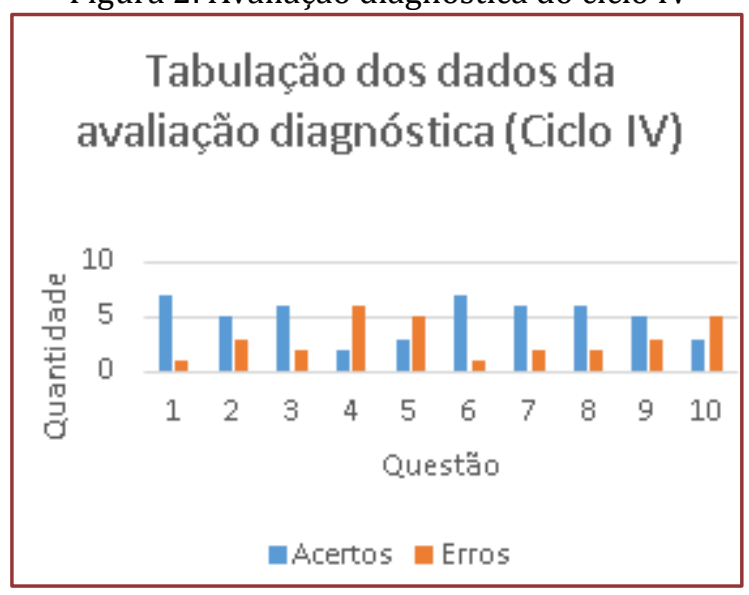

A partir da tabulação e sistematização dos dados obtidos por meio da avaliação diagnóstica, identificamos que a unidade temática 'grandezas e medidas' foi a de maior desempenho dos alunos, bem como a unidade 'geometria' apresentou maior déficit. Essas informações contribuíram para criar estratégias para a superação das dificuldades de aprendizagem do componente curricular matemática, sobretudo, da unidade temática "geometria" por meio da elaboração de um instrumental metodológico compostos pelos jogos: bingo das frações, jogo com o Tangram, jogo com palitos, dinâmica do guia financeiro e jogo com baralhos. Esses jogos foram planejados, produzidos e estão em fase conclusiva de aplicação.

\section{ATIVIDADES LABORAIS APLICADAS AOS ALUNOS DOS CICLOS III E IV DA EJA}

A primeira atividade laboral consiste na utilização do jogo com palitos. Como construir se o aluno optar por fósforos? Antes de começarmos a experimentar truques e brincadeiras com fósforos, foi conveniente acender todos e apagar rapidamente um a um para evitar acidentes. Ao acender os fósforos, em vez de riscá-los no sentido do comprimento é melhor riscar no sentido da largura da caixa, pois a área de atrito demora mais a se gastar. Inicialmente, foi feita uma revisão de geometria plana e do sistema de numeração romano.

A atividade foi aplicada após uma breve explicação de como funcionaria. Organizamos a sala de aula em duplas de trabalho. Distribuímos os palitos e foram socializados alguns desafios, sendo aplicado um desafio por vez, assim que concluído o anterior e todos terem compreendido do que se tratava. Os alunos mostraram interesse e curiosidade pela atividade, participando de maneira ativa, mostrando o quão 
interessante acharam o jogo. Sabendo os conhecimentos que eram requisitados nos desafios, foi possível ver que no início da atividade os alunos estavam dominando o conteúdo, porém com receio de executar o que lhes eram propostos. Problema esse que foi resolvido ao ir dando-os confiança em seus conhecimentos. Assim, a atividade tornou-se satisfatória para eles a cada objetivo alcançado.

A segunda atividade laboral consiste na utilização do Tangram que é um quebra-cabeça milenar e um dos mais ricos em conteúdos matemáticos. Através do Tangram exploramos diversos assuntos, tais como: frações, desafios, área de figuras planas, jogos e outros. Por meio do jogo da subtração com o Tangram foi mostrado como utilizar suas características.

\section{Regras do jogo:}

- Iniciar com par ou ímpar.

- São dois jogadores.

- Vence aquele que completar a figura primeiro.

- A subtração é feita partindo da face maior do dado para face menor.

- $\quad$ No final se o jogador retirar mais do que precisa, não pode sobrar peças, logo você deve retirar da sua cartela aquela quantidade indicada pelo dado.

- $\quad$ Se o resultado for zero passa-se a vez.

Material para 4 jogadores:

- 1 cartela na forma de triângulo dividido em 16 partes triangulares.

- 1 cartela na forma de quadrado dividido em 16 partes triangulares.

- 1 cartela na forma de retângulo dividido em 16 partes triangulares.

- 1 cartela na forma de trapézio dividido em 16 partes triangulares.

- 20 peças do triângulo pequeno.

- 8 peças do triangulo médio (cada triangulo médio vale 2 triângulos pequenos).

- 8 peças do quadrado (cada quadrado vale 2 triângulos pequenos).

- 6 peças do triângulo grande (cada triangulo grande vale 4 triângulos pequenos).

- 2 dados.

Na aplicação do jogo subtração com o Tangram, a abordagem da temática foi realizada por meio de uma breve explanação na perspectiva história do surgimento desse quebra-cabeça. A sala de aula foi organizada em grupos com 05 (cinco) integrantes. Em seguida, os bolsistas explicaram os objetivos e regras do jogo e apresentaram o material usado para sua confecção. Durante a realização da atividade observamos o envolvimento dos alunos com o jogo desde o espírito competitivo, a criação de estratégias para vencer até a vontade de jogar várias vezes para vencer pelo menos uma vez. 0 primeiro grupo a jogar foi o que sentiu mais dificuldade, devido ao fato de ter iniciado as partidas e os demais grupos se sentiram mais à vontade para jogar por terem observado o primeiro grupo. Desse modo, ficou compreendido a importância da atividade, a ampla participação e o bom desempenho dos alunos no decorrer dos desafios. Ao serem questionados sobre o jogo no final da aplicação, os alunos participantes demonstraram entusiasmo e uma boa assimilação dos conteúdos abordados.

A terceira atividade laboral consiste na utilização do jogo com baralho. Foi confeccionado um baralho com um total de vinte cartas, contendo valores de 1 a 10 e equações do primeiro grau. Com as cartas em mãos, foi necessário dividir os alunos em grupos. Em seguida, as cartas foram embaralhadas e distribuídas entre os grupos. 0 jogo foi dividido em partidas, onde um aluno iniciava jogando uma de suas cartas e os demais jogavam em sequência. $O$ aluno que tivesse jogado a carta de maior valor ganhava a partida e consequentemente as cartas da mesa. Em caso de empate dos valores das cartas, ganhava a carta que tivesse a equação.

A aplicação do jogo com baralhos sucedeu-se de forma sucinta, porém bastante proveitosa para os alunos. Em certos momentos, alguns alunos demonstraram dominar o conteúdo no decorrer do jogo, todavia tiveram dificuldades em responder algumas equações. Apesar disso, expressaram entusiasmo e esforços para obterem as respostas. Desse modo, o jogo estimulou a turma a não desistir até conseguir os objetivos, além de contribuir para a assimilação do conteúdo.

A quarta atividade laboral consiste na utilização do bingo de frações. Para sua confecção foi impresso um total de 04 (quatro) cartelas em uma folha A4 e em seguida plastificadas e cortadas. 0 mesmo foi feito para as fichas do sorteio, todas as representações na forma numérica das frações (sem repetições) das cartelas foram impressas e cortadas. Inicialmente, a sala de aula foi organizada em 04 (quatro) grupos. Em seguida, foi definido um representante para cada grupo. Cada representante escolheu uma cartela com 
representações geométricas das frações. Posteriormente, foi sorteada a representação numérica das frações correspondentes. 0 grupo que conseguisse preencher primeiro a cartela ganharia a competição.

Dado início a atividade, as frações que iam sendo chamadas eram escritas no quadro branco para facilitar a marcação dos resultados na cartela. Alguns grupos tiveram dificuldades em identificar estas frações no decorrer do jogo e outros se destacaram por apresentar rapidez em distinguir e marcar as frações na cartela. Foi possível perceber um maior entendimento quanto ao conteúdo matemático abordado, a interação e o entusiasmo dos alunos entre si, bem como com os bolsistas. Todos demonstraram gostar da dinâmica, assim possibilitando sua participação.

A quinta atividade laboral consiste na utilização de um guia financeiro que foi elaborado a partir da pesquisa bibliográfica, sendo selecionado os mais adequados assuntos para o público-alvo em questão. 0 objetivo compreendeu em resolver situações-problema sobre a matemática comercial e financeira, propiciando conexões com os temas transversais 'trabalho e consumo'. Para tanto, foi abordado o consumismo que permeia o ambiente escolar, sendo elaborado um guia repleto de dicas para ajudá-los nessa missão. Posteriormente, foi feita a confecção do guia propriamente dito, em forma de livreto, que contêm dicas e algumas curiosidades. Ao término da sua confecção, foram distribuídos aos alunos de forma que pudessem retomar atitudes e hábitos na sua vida econômica. Esta atividade potencializou a produção textual, a capacidade de investigação, a capacidade de diálogo, a autonomia e a criatividade.

Na execução do guia financeiro, foi introduzido o assunto sobre reeducação financeira através de slides apresentados no datashow, sendo elencados pontos importantes do seu cotidiano. Ademais, foram produzidos cofres no formato de porquinhos, sendo utilizado EVA e garrafa pet para sua confecção. Ficou perceptível a alacridade e colaboração dos alunos na atividade, que se seguiu de forma satisfatória e abrangente quanto aos conteúdos abordados.

Quanto ao desenvolvimento das atividades, os alunos potencializaram: a compreensão - facilidade para entender o processo do jogo assim como o autocontrole e o respeito a si próprio; a facilidade possibilidade de construir uma estratégia vencedora; a possibilidade de descrição - capacidade de comunicar o procedimento seguido e da maneira de atuar e a estratégia utilizada - capacidade de comparar com as previsões ou hipóteses.

\section{ALGUMAS CONSIDERAÇÕES}

A partir deste estudo foi possível perceber algumas dificuldades frente aos objetos de conhecimento da matemática da etapa do ensino fundamental da educação básica, dos alunos da modalidade EJA (ciclos III e IV) da escola campo Crispim Coêlho. Destarte, a ação de um reforço escolar, em uma perspectiva do subprojeto da área da matemática do Pibid, ou seja, a partir do uso das metodologias ativas e abordagem do letramento matemático por meio da ludicidade e apropriação dos jogos educativos se faz necessária uma vez que o contato do aluno com novas maneiras de se trabalhar o conteúdo abordado em sala de aula se distancia das aulas tradicionais.

A vivência durante o estudo trouxe novas perspectivas para os bolsistas, ajudando-os no desenvolvimento de novos olhares para a maneira de como se deve expor os objetos de conhecimento matemático para o aluno. A aquisição das habilidades é percebida ao longo das práticas exercidas, bem como o pensamento crítico e a criatividade. Estas são de grande importância para a formação do professor comprometido com o processo educativo de qualidade.

A partir da observação participativa, no percurso das práticas laborais, depreendemos que a ludicidade possibilita a (des)construção de um ambiente de ensino e aprendizagem da matemática caracterizado pela sua forma exaustiva, configurando-se como uma estratégia pedagógica potencial para todo processo educativo. Em suma, foi verificado o interesse e a motivação dos alunos ao participarem das atividades laborais aplicadas, bem como desempenharam-nas de forma satisfatória. Todas as atividades foram imprescindíveis para a aprendizagem do referido público-alvo, tendo em vista algumas dificuldades todos foram proativos em assimilar os conteúdos abordados por meio da ludicidade.

Podemos concluir que a ordenação e apropriação dos jogos educativos nas aulas de matemática é um campo complexo no que concerne seu ensino. Ademais, foi possível refletir sobre de que forma essas atividades assistiram e ampliaram os objetivos de ensino já supracitados, pois a essência da prática pedagógica por meio de projetos acontece a partir de um planejamento comprometido com um fazer matemática dirigido a demanda do público-alvo em questão. 


\section{REFERÊNCIAS}

[1] Alves, D. L. A importância do reforço escolar. Revista Farol, Rondônia, v. 6, n. 6, p. 29-37, 2018.

[2] Brasil. Parâmetros Curriculares Nacionais. Brasília: MEC/SEF, 1998.

[3] _ Instituto Nacional de Estudos e Pesquisas Educacionais Anísio Teixeira (INEP). Matriz de avaliação de matemática. 2013.

[4] ___ Base Nacional Comum Curricular (BNCC). Educação é a Base. Brasília, MEC/CONSED/UNDIME, 2017.

[5] D’ambrósio, B. S. Como ensinar matemática hoje? Temas e Debates, 1989. Disponível em:https://sites.google.com/site/profrafaelalmeida01/ensino/metodologia-do-ensino-

dematematica/D\%27Ambrosio-Comoensinarmatem\%C3\%A1ticahoje.pdf. Acesso em: 15 de maio 2019.

[6] Gonçalves, H. A. O conceito de letramento matemático: algumas aproximações, 2010. Disponível: ww.ufff.br/virtu/files/2010/04/artigo-2a14.pdf. Acesso em: 06 de junho de 2019.

[7] Grando, R. C. O conhecimento matemático e o uso de jogos na sala de aula. 2000. 224 f. Tese de Doutorado em Educação - Faculdade de Educação. Universidade de Campinas, Campinas, São Paulo.

[8] Lopes, S. P.; Sousa, L. S. EJA: uma educação possível ou mera utopia? Revista Alfabetização Solidária, v. 5, 2005.

[9] Miorim, M. A.; Fiorentini, D. Uma reflexão sobre o uso de materiais concretos e jogos no Ensino da Matemática. Boletim da SBEM-SP, São Paulo, v. 4, n. 7, p. 5-10, 1990.

[10] Morán, J. Mudando a educação com metodologias ativas. Souza, C. A. de.; Morales, O. E. T. (Orgs.). Convergências Midiáticas, Educação e Cidadania: aproximações jovens. v. 2. PG: Foca Foto-PROEX/UEPG, 2015. Coleção Mídias Contemporâneas. 


\section{Capítulo 9}

O pedagogo e a formação do PAFOR: A práxis no ensino de história no interior da Bahia

\section{Keite Maria Santos do Nascimento Lima}

Resumo: 0 artigo discute os impactos do curso de pedagogia do Plano Nacional de Formação de Professores da Educação Básica- PARFOR/UNEB - na adoção de novas posturas e metodologias, no ensino história, admitidas pelos pedagogos, da rede municipal de ensino de Alagoinhas- BA. 0 interesse pela pesquisa está diretamente relacionado a minha experiência como docente/ formadora desses professores. Ministrando os componentes curriculares Ensino de História I e II e Oficinas de ensino na área específica, no município, ficou evidente o desconhecimento sobre conceitos históricos e a importância dessa área de conhecimento enquanto disciplina escolar. Os depoimentos dos professores/estudantes, sujeitos da pesquisa, durante as aulas, em relação aos desafios para ensinar História; a aversão dos estudantes à disciplina; as dificuldades dos pedagogos para se apropriarem de conceitos próprios das ciências humanas e entender as relações sociais; as dificuldade para selecionar e organizar os conteúdos, assim como, a questão das experiências vividas pela humanidade no tempo espaço nos levou às seguintes questões: como esses professores/pedagogos entendem e ensinam História? Em que medida a Formação inicial auxiliou a práxis desses profissionais ao que tange ao processo de ensino-aprendizagem de História? Ocorreu realmente o desenvolvimento de um conhecimento histórico escolar? As informações socializadas foram coletadas durante um ano, utilizando o método de pesquisa qualitativa. Através de entrevistas, observação participante e análise de documentos como os planejamentos e as sequências didáticas discutimos a Formação e os saberes históricos mobilizados em sala de aula pelos pedagogos (as) no curso de Pedagogia do PARFOR- da cidade de Alagoinhas ao lecionar história. 


\section{INTRODUÇÃO}

Segundo a Resolução CNE/CP no1/2006, o estudante de pedagogia trabalha com um repertório de informações e habilidades composto por pluralidade de conhecimentos teóricos e práticos cuja consolidação se dará no exercício da profissão. Será que essa pluralidade de saberes dá condição teórica e metodológica para que o pedagogo possa trabalhar conteúdos históricos?

Essa e outras inquietações surgiram em uma perspectiva de verificar como os futuros pedagogos, lecionam, entendem e ensinam história nas Séries Iniciais do Ensino Fundamental I? Como esses profissionais a partir de uma formação tão plural conseguem transmitir os conhecimentos específicos da disciplina? De que maneira a formação inicial universitária contribuiu para ressignificar as bases, os métodos os conceitos históricos mobilizados no ensino de História em sala de aula?

Problematizar o Ensino de História a partir de um olhar sobre a atuação do pedagogo em formação que participa do Plano Nacional de Formação de Professores da Educação Básica - PARFOR/UNEB na cidade de Alagoinhas foi um desafio para uma historiadora que percebeu na experiência vivenciada ora como professora da educação básica ensinando história ora como orientadora desses profissionais da educação - que em virtude de uma formação generalizada e complexa os pedagogos sentem dificuldades para se apropriarem de concepções teórico-metodológicas do ensino de História, assim como das especificidades do ensino dessa disciplina - a necessidade de discutir se o curso de formação voltado para professores em exercício na Educação básica atribuiu um novo significado a práxis desses profissionais.

Muitos professores ensinam história da maneira que aprenderam durante sua escolarização. E a História que aprenderam é tributária "[...] de determinados conteúdos 'tradicionais' e do método da 'memorização', responsável por um slogan famoso da História escolar: 'uma matéria decorativa' por excelência" (BITTENCOURT, 2009, p.60). Assim, ensinar História se resumia a comemoração de datas cívicas, tais como a Independência do Brasil, a Proclamação da República, o Dia do Índio, etc. que, com outras datas consideradas importantes como o aniversário da cidade faz parte do currículo de História ensinado.

A opção por trabalhar os docentes que estavam sendo formados no Curso de pedagogia do PARFOR se dá principalmente, pela peculiaridade dessa política nacional de formação de professores primar por qualificar educadores (as) no exercício da docência possibilitando uma transposição didática mais eficaz. Assim, acredito que apesar dos numerosos desafios que o professor enfrenta como dispor de pouco tempo para as leituras e pesquisas, não podemos deixar de sinalizar que ao proporcionar uma Formação na qual o estudante concomitante ao processo de graduação se mantém em exercício de sua função pode superar a divisão histórica entre saberes produzidos na academia e os saberes mobilizados no chão da escola.

\section{METODOLOGIA}

A discussão ora proposta vincula-se à área de Educação sem perder de vista sua inter- relação com a História. Ao articular a reflexão entre as aprendizagens ocorridas na graduação em Pedagogia pelo PARFOR/UNEB e a possível ressignificação das práxis do pedagogo no ensino de História nos Anos Iniciais do Ensino Fundamental, optei pela abordagem qualitativa, fazendo uso, nesta pesquisa, de relatos de experiências e análise de fonte primária como os documentos como os planejamentos e as sequências didáticas são fontes importantes para analisarmos como é teorizado o ensino de História e como ele ocorre na prática.

Essa escolha está pautada na liberdade que o estudo possibilita ao investigador tanto a ampliação de suas fontes "[...] os pesquisadores qualitativos geralmente coletam múltiplas formas de dados, tais como entrevistas, observações e documentos, em vez de confiarem em uma única fonte de dados [...] (CRESWELL,2010,p.208) quanto possibilita "[...] a interpretação em lugar da mensuração, a descoberta em lugar da contestação, valorização a indução e assume que fatos e valores estão intimamente relacionados" (ANDRÉ, 2002, p.17).

É importante sinalizar que a pesquisa no campo educacional na perspectiva qualitativa dá condição ao pesquisador ampliar o olhar sobre o contexto e as práticas vivenciadas pelos sujeitos, assim como, possibilita uma riqueza de informações acerca das experiências e das formas como os sujeitos se relacionam com o social. Dessa forma, a interação constante entre o pesquisador e o objeto pesquisado; a ênfase no processo; a preocupação com o significado e o trabalho de campo são características que direcionam a pesquisa para uma abordagem qualitativa.

Ao escutar as histórias dos professores, os relatos de suas experiências em sala de aula e ao lecionar 
conteúdos históricos, busquei dá significado as falas a partir não só das práticas desenvolvidas em sala de aula mas relacionar às suas práticas culturais. Entender como esses professores aprenderam história durante sua escolarização, e como essa experiência o influenciou em sua prática.

Para uma pesquisa que transita entre duas áreas a Educação e a História, este trabalho, propõe-se do ponto de vista historiográfica em debate uma abordagem mais específica no campo da própria História Cultural, a investigação será aprofundada a partir dos trabalhos de Burke (1992,2005), Cardoso (1997), Le Goff $(1976,1998)$, Pesavento (2005) dentre outros. Para tematizar a questão da formação de professores e ensino de História irei pautar-me em estudos como os de Bittencourt (2004), Fonseca (1993), Nóvoa $(2000,2002)$ Perrenoud $(2000,2002)$, Tardif (2002), dentre outros.

Em março de 2013, iniciei o estudo com os futuros pedagogos que comporiam o corpus de análise. 0 critério de escolha dos vinte sujeitos da pesquisa seguiu os seguintes critérios: a) ter integrado o corpo discente do Plano Nacional de Formação de Professores da Educação Básica - PARFOR/UNEB- Alagoinhas; b) atuar no Ensino Básico Municipal; c) ter cursado a disciplina História I e II; d) ter cursado a Oficina de Ensino de História oferecido pelo curso.

Ao longo das aulas de Ensino de História I os depoimentos das professoras despertaram o interesse pela realização da pesquisa. A escuta atenta às inquietações, preocupações e avanços conquistados nas aulas de história ministradas pelos professores/estudantes, junto aos seus alunos, assim como, o acompanhamento aos planejamentos e as sequências didáticas possibilitou a presente pesquisa em torno das problemáticas que envolvem o ensino de História, o pedagogo e sua prática pedagógica nos Anos Iniciais do Ensino Fundamental das cidades de Alagoinhas.

\section{RESULTADOS E DISCUSSÃO}

A implantação do PARFOR deu condição a muitos docentes, em exercício, das redes públicas a frequentarem cursos de graduação, seja na modalidade presencial ou à distância. A parceria entre estados e municípios tornou possível, em tese, que esses profissionais, que têm larga experiência em sala de aula, pudessem se apropriar de discussões metodológicas e teóricas que viessem a contribuir para suas práxis e, assim, atuarem na educação infantil e no ensino fundamental (1ำ ao $5^{\circ}$ ano) de maneira mais significativa.

Foi o decreto no 6.755 de janeiro de 2009 que institui a "Política Nacional de Formação de Profissionais do Magistério da Educação Básica" tendo "[...] como objetivo principal assegurar a formação de professores das redes públicas da educação básica" (SANTOS; CHAPANI; SOUZA, 2012, p. 5).

A Universidade do Estado da Bahia UNEB, que desde 1998 investe em Programas Especiais de Formação em Exercício para Professores com atuação na Educação Básica, se disponibilizou a implementar e assumir nas microrregiões onde estão sediados seus Departamentos os Cursos do Plano Nacional de Formação de Professores da Educação Básica- PARFOR.

Em 2012 o Conselho Estadual de Educação (CEE) por meio do Parecer no 306/2012 autorizou a Proposta Pedagógica inicial do Curso de Pedagogia - Licenciatura da PARFOR/UNEB (PPP/UNEB/PARFOR, 2013, p. 57).

Para que a operacionalização dos cursos de Graduação ocorresse na região, a Universidade firmou parcerias entre UNEB/MEC- CAPES e UNEB/Prefeituras dos municípios interessados, na oferta dos cursos para os professores que ainda não possuíam a primeira graduação (PROJETO POLÍTICO PEDAGÓGICO CURSO DE LICENCIATURA. UNEB/PARFOR, p.57).

Destarte, a estrutura curricular do curso foi pensada a partir das Diretrizes Curriculares Nacionais para o Curso de Graduação em Pedagogia, licenciatura na Resolução CNE/CP n.1, de 15 de maio de 2006. A Resolução em pauta tem por premissa que o estudante de pedagogia deverá trabalhar com um repertório de informações e habilidades composto por pluralidade de conhecimentos teóricos e práticos cuja consolidação será efetivada no exercício da profissão. No PPP do curso de pedagogia UNEB/PARFOR (2011, p.53) ao tratar das características do trabalho do pedagogo(a) tendo por subsídio a Resolução acima supracitada, adverte: 
[...] estamos falando de um trabalho que, além de produção e consumo, envolve um saber fazer em fluxo, que não abre mão do saber instituído, mas se alimenta dele, porém, para se atualizar, de modo criativo e desejavelmente crítico e emancipatório, se faz coletivo. Neste caso, somos instados a dialogar com o campo da gestão das organizações educacionais, em termos reflexivos, para compreender como se dá a micropolítica do trabalho educacional, no qual os nossos formandos estão em exercício.

A Secretaria da Educação de Alagoinhas - SEDUC - assinou um convênio, em 2010, com a Universidade Estadual da Bahia. 0 Departamento de Educação - Campus II- Alagoinhas, disponibilizou 90 vagas para docentes da Rede de ensino e 30, destas, foram para o curso de pedagogia. A rede municipal tinha, nessa época, mais de 100 profissionais da educação não habilitados, assim o curso da PARFOR aparecia como uma alternativa formativa para esses professores que não tinham o curso de graduação plena.

O Curso de Pedagogia- Licenciatura do Plano Nacional de Professores da Educação Básica- PARFOR/UNEB calcado no pressuposto de que as práticas formativas devem ocorrer na inter-relação entre as experiências, as práticas docentes dos professores e os conhecimentos acadêmicos tenta assegurar ao professor/estudante uma formação plural, significativa na qual como sujeito do processo evidencia a valorização de sua experiência, seus saberes, a escola e seus projetos (NÓVOA,2002). Há uma tentativa de aliar prática e teoria, já que uns dos critérios para cursarem a graduação é que esses professores estejam em efetiva regência de classe. No Projeto Político Pedagógico do curso de Pedagogia da UNEB/PARFOR essa questão é sinalizada nos seguintes termos:

Dentro destas especificidades, destaca-se o caráter intensivo de formação, associado às experiências e práticas docentes do estudante, de forma a garantir um dos seus princípios básicos - a articulação da teoria com a prática, sem perder de vista a qualidade desse processo [...]" (Ibidem, p.62) (grifos nosso).

Contudo, percebemos que essa situação de professor/estudante é delicada no sentido de esses profissionais, em sua grande maioria, não disponibilizarem de um tempo significativo para se dedicar às leituras, pesquisas além das dificuldades para participar de Simpósios, Workshop, Seminários que agregam saberes à sua formação continuada. 0 artigo 67 da LDB/1996 no inciso $\mathrm{V}$ postula que está incluído na carga de trabalho a necessidade dos estudantes em formação terem tempo para leitura, planejamento e avaliação sem comprometer sua Formação. Entretanto a realidade apresentada no depoimento de uma das professoras retrata o abismo entre a teoria e a prática:

Na maioria das vezes não temos tempo para estudar em casa. Muito menos participar de encontros fora de nossa cidade. Participar das aulas já é sacrifício, imagine ter que viajar... É muito difícil ser professora e estudante ao mesmo tempo. Tenho a impressão que não estou aproveitando as aulas como deveria, porque estou sempre cansada e preocupada... ( PROFESSORA D).

Ao lecionar para esses professores, futuros pedagogos, pude observar os desafios que enfrentavam ao participar de um projeto de formação em serviço. As dificuldades se acumulavam quando entravam em contato com os saberes constituídos dos componentes curriculares trabalhados e a complexa natureza de sua formação que se desdobra entre o desenvolvimento de funções de magistério na Educação Infantil e no Ensino Fundamental (Anos Iniciais), quanto para exercer a gestão em espaços escolares e não escolares, se debatem em torno da afirmação e legitimação profissional.

Diante de uma pluralidade de conhecimentos teóricos e práticos necessários ao desenvolvimento de habilidades e competências desses profissionais se faz urgente uma reflexão sobre a interface entre a formação específica do pedagogo e os saberes mobilizados no ensino de História.

Ao ministrar aulas do componente curricular Ensino de História I e II para os professores e as professoras/estudantes de Pedagogia da UNEB/PARFOR na cidade de Alagoinhas em 2013, assim como, a oportunidade de conduzir um Seminário temático, de 30h, que discutia a adoção de novas metodologias no ensino de História, no ano de 2014, trouxe à tona algumas inquietações que já faziam parte do rol de minhas reflexões no exercício da docência em História há 15 anos.

0 estudo sobre a formação de professores, o ensino de História e sua relação com a prática em sala de aula vem ao longo de algumas décadas fazendo parte das pesquisas de educadores e historiadores. É importante sinalizar que a Associação Nacional de História- Seção Bahia (ANPUH-BA) vem avançando nas 
discussões sobre o ensino de História na perspectiva de aproximar um campo de pesquisa que por sua natureza se aproxima da educação. Para Monteiro, o ensino de História "[...] se legitima e se afirma tanto nos espaços institucionais de produção do conhecimento na área de Educação quanto na área de História" (2004, p.7).

Ações como a implantação do GT Ensino de História e Educação e o II Encontro de Ensino de História da Bahia (UFRB, 2013) marca o diálogo com os inúmeros profissionais de História que atuam na Educação Básica. O VII Encontro Estadual de História realizado na Universidade Federal do Recôncavo da Bahia (UFRB) em 2014 intensificou o estreitamento de laços entre o pesquisador/historiador que se debruça sobre o ensino de história e o campo da educação. Nesse evento, dos oito Minicursos/Oficinas disponibilizados para os participantes, dois discutiram Ensino de História. E ainda, dos vinte dois Simpósios temáticos três foram voltados para essa temática.

Contextualizar, a trajetória das discussões do ensino de História em eventos voltados para historiadores é relevante à medida que percebemos que na Bahia esse campo de pesquisa tem buscado, de forma sistemática, contribuir para o pensar e repensar os diferentes significados da História, a importância de estudar história na educação básica e colocar em debate que tipo de professores às universidades vem formando para atuar no Ensino Fundamental Anos Iniciais. Segundo Elza Nadai:

[...] devemos buscar conhecer e explicitar a trajetória de constituição da História enquanto disciplina pedagógica. Nesse movimento, se reconhecem e se elucidam, também, os agentes contemplados, seus interesses aceitos bem como os negados. As perspectivas surgirão do seu bojo e deverão da conta de encontrar e esclarecer a ação e contribuição do conjunto dos agentes sociais presentes na história e não somente dos privilegiados tradicionalmente. Esse é o grande desafio a que nós professores e pesquisadores de História devemos responder (2014, p.35).

Partimos da premissa de que a formação de professores é complexa à medida que mobiliza saberes e práticas diversas. Neste contexto, lecionar História para o pedagogo é mais complicado ainda, pois estes, ao desconhecer a maioria dos conceitos históricos, a linguagem e a maioria das produções historiográficas, sentem-se perdidos e desmotivados para ensinar História. Como ensinar o que não se sabe? Como produzir, ampliar e transmitir conhecimento se o desconheço? Eis a questão!

Nas primeiras aulas de Ensino de História I para os professores/estudantes do Curso de Pedagogia do PARFOR/UNEB solicitamos aos professores/estudantes a definição do que é História. Para eles, a História estava associada às datas e fatos históricos, vista como um instrumento pedagógico na constituição de uma identidade mais local nacional. 0 que ficou evidente nas falas da maioria dos estudantes/professores que ao serem solicitados a rememorarem uma aula de História foram unânimes em socializarem aulas referentes a História das Comunidades em que atuam.

Ao se posicionarem sobre o que é História, enquanto disciplina escolar, ficou evidente a ausência do domínio dos conceitos históricos; uma submissão ao conhecimento trazido pelo livro didático; a desvalorização e o desinteresse pelo conhecimento da disciplina o que leva-nos a reproduzirem deste conhecimento para os educandos que passam ver a História como uma disciplina chata, sem sentido, pois acreditam que estudar história é decorar datas e fatos.

As narrativas recuperaram nas lembranças, dos pedagogos pesquisados, como aprenderam história. Para a Professora B:

Lembro que as aulas de História demoravam a acontecer. Somente próximo de um feriado que a professora trazia geralmente a figura de herói de nossa pátria. Ah, e tinha as cópias enormes...era chato demais. Sempre entendi que História era para aprender coisas da Nação... Eu fazer parte da História? ... Nunca!

Depreende-se assim que as dificuldades dos professores para direcionar o ensino de História para as crianças é um desdobramento das concepções, visões, estereótipos que ao longo de sua vida escolar foram consolidadas. "O que ensinar "da História/em História, "para que ensinar" e por que ensinar" História (FREITAS, 2010) são questões que angustiam os pedagogos todas as vezes que são "obrigados" a elaborarem um planejamento ou uma sequência didática para ministrar aulas de História.

Os planejamentos analisados antes de cursarem os componentes curriculares de História mostravam uma preocupação em demasia com o conteúdo, com os fatos, muitos ainda davam ênfase a data o que demonstrava ainda uma perspectiva de um ensino que primava por ser decorativo. A história descrita 
naqueles planos de aula estava distante da realidade do estudante. Assim, um grande desafio se avizinhava: além de mostrar a importância da disciplina no currículo escolar e na formação do estudante se fazia urgente desmistificar a ideia de que a aquisição do conhecimento histórico se limita a uma série de fatos objetivos. Uma das falas de uma professoras/estudantes vem ratificar esse conceito raso de história: "[...] começamos a aula arrumando o nosso cantinho da não demorou muito eles pediram para que eu contasse uma história, era tudo que eu estava esperando pois o conteúdo da aula seria "HISTÓRIA". (PROFESSORA E)

A escolha de textos da historiografia que se debruça sobre o ensino de história, textos teóricos que dão conta da epistemologia do conhecimento histórico a socialização das experiências possibilitaram problematizar: a permanência da condição reprodutivista do conhecimento histórico ensinado nas escolas; problemática do livro didático de História; problemática da história dos vencedores; concepção temporal que separa passado do presente de forma a entender o tempo como sucessão de fatos cristalizados.

Essa preocupação em possibilitar a esses professores/estudantes aprender e ensinar História norteou a condução dos componentes curriculares ministrados. Pois, no decorrer deste processo a experiência e a troca de saberes me levaram a refletir:

[...] é possível levar a aprender sem ensinar? Se o professor não tiver clareza sobre o sentido e aplicação de conceitos como cidadania, diferença, semelhança, permanência, transformação, questionamento, convivência e outros que compõem o vocabulário dos programas e materiais de ensino, como será possível conduzir ou mesmo participar de um projeto de aprendizagem? (MICELI,2014, p.40).

Os desafios apresentados são muitos, os dilemas desses pedagogos mais ainda. Entretanto, percebeu-se que a apropriação dos conceitos fundamentais da História numa perspectiva da construção intelectual de teorias, ideias e representações a partir do componente curricular Ensino de História I e II implicou em mudanças na visão do Pedagogo do que é História e da importância dessa disciplina para a formação integral do indivíduo. A prática desses pedagogos foi repensada e reavaliada. Houve realmente a produção de um saber histórico entre os "muros" da Universidade que de alguma forma vem se desdobrando na prática pedagógica dos Pedagogos formados no Campus II da UNEB/PARFOR na cidade de Alagoinhas.

\section{CONSIDERAÇÕES FINAIS}

O ensino de História e a atuação dos professores da educação básica se configuram como um campo de pesquisa em processo de constituição. Como historiadora e professora perscrutar sobre os significados da palavra História para os pedagogos em formação, sujeitos da pesquisa, assim como discutir as experiências desses professores com o ensino dessa disciplina, me fez perceber a necessidade de uma investigação que discutisse as singularidades e evidenciasse a contribuição de uma política educacional voltada para a formação de professores em exercício na ampliação de conceitos, abordagens metodológicas e a construção de novos significados no ensino de História.

Então, o meu intuito em pesquisar a práxis dos pedagogos, formado pelo PARFOR/UNEB, no ensino de História da cidade de Alagoinhas, objetivou evidenciar a ressignificação dos conceitos caros a História pelos pedagogos e pontuar as possíveis mudanças, os novos desafios e as perspectivas que por ora faziam parte desse novo Professor que foi se consolidando ao longo dos anos de formação.

Da escuta das experiências socializadas pelas professoras, sujeitos, deste estudo, percebi como o investimento na profissionalização fez a diferença no fazer pedagógico. Muitas superaram a condição de serem consumidores e passaram a produtores de conhecimentos. Ao ampliar suas bases teóricas e metodológicas os pedagogos superaram a superficialidade de suas aulas e compreenderam como utilizar os conhecimentos históricos em sua vida e em suas aulas. A partir de uma abordagem focada no estudante, atento ao que pensam, como aprendem, quais suas potencialidades deram mais sentido ao projeto educativo desses pedagogos. É fato, que ainda existem muitos desafios a serem vencidos, contudo nota-se que o ensino de História, em algumas salas de aula da rede municipal de educação de Alagoinhas, nos primeiros anos de escolarização está mais comprometido com as aprendizagens das crianças. 


\section{REFERÊNCIAS}

[1] André, Marli Eliza Dalmazo Afonso de. Etnografia da prática escolar. 7ed. Campinas, SP: Papirus: Série Pedagógica,2002.

[2] Bittencourt, Circe Maria F. Ensino de História: fundamentos e métodos.3o ed. São Paulo: Cortez, 2009.

[3] Brasil. Lei n. 9.394, de 20 de dezembro de 1996. Estabelece as diretrizes e bases da educação nacional. Brasília, Dou, ano Cxxxiv, n. 248, p. 27833 - 2784.

[4] Brzezinski, Iria. LDB/1996 contemporânea: contradições, tensões, compromissos. São Paulo: Cortez, 2014. p. 112-143.

[5] Burke, Peter. (Org.). O que é história cultural? Rio de Janeiro: Jorge Zahar Ed. 2005.

[6] Cardoso, Ciro; Vainfas, Ronaldo. Domínios da História. Ensaios de teoria e metodologia. Rio de Janeiro: Campus, 1997.

[7] Fonseca, Selva Guimarães. Caminhos da história ensinada. 6. ed. Coleção Magistério: Formação e trabalho pedagógico. Campinas, SP: Papirus,1993.

[8] Freitas, Itamar. Fundamentos teórico-metodológicos para o Ensino de História (Anos Iniciais). São Cristóvão: Editora UFS,2010.

[9] Horn, Geraldo Balduíno; Germinari, Geyso Dongley. O ensino de história e seu currículo: Teoria e método.4.ed. Petropólis, RJ: Vozes, 2011.

[10] Le Goff, Jacques. A história nova. (Tradução Bernardo Leitão et al.) São Paulo: Martins Fontes,1998.

[11] Miceli, Paulo. Uma pedagogia da História? In: Pinsky, Jaime. [et.al]. $O$ ensino de história e a criação do fato.14. ed. $2^{\underline{a}}$ reimpressão. São Paulo: Contexto, 2014.

[12] Monteiro, Ana Maria; Gasparello, Arlete Medeiros; Magalhães, Marcelo de Souza (Orgs.) Ensino de história: sujeitos, saberes e práticas. Rio de Janeiro: Mauad X: Faperj, 2007.

[13] Nadai, Elza. O ensino de História e a "pedagogia do cidadão". In: Pinsky, Jaime. [et.al].0 ensino de história e a criação do fato.14ed. 2⿳亠丷⿵冂⿱⺊口灬 reimpressão. São Paulo: Contexto, 2014.

[14] Nóvoa, António. Formação de professores e trabalho pedagógico. Lisboa: Educa, 2002.

[15] Perrenoud, Philippe. A prática reflexiva no ofício do professor: profissionalização e razão pedagógica. (Tradução: Cláudia Schilling) Porto Alegre: Artmed, 2002.

[16] Santos, Sueli Bião; Chapani, Daisi Teresina; Souza, Marcos Lopes de. Formação e atuação de professores de ciências (não habilitados) participantes de um curso de licenciatura vinculado ao Parfor. Anais do XVI EndipeEncontro Nacional de Didática e Práticas de Ensino - Unicamp- Campinas-2012.

[17] Silva, Marco Porto; Porto, Amélia. Nas trilhas do ensino de história: teoria e prática.1 ed. Belo Horizonte: Roma,2012.

[18] Tardif, Maurice. Saberes docentes e formação profissional. Petrópolis, RJ: Vozes,2002.

[19] Universidade do Estado da Bahia. Pró-Reitoria de Ensino de Graduação- Prograd. Plano Nacional de Formação de Professores da Educação Básica. Projeto Político Pedagógico- Curso de Pedagogia- Licenciatura. Salvador- BA. Setembro de 2013. 


\section{Capítulo 10}

\section{Aula de campo como recurso metodológico para o ensino de geografia física}

\section{Patrícia Araújo de Sousa}

Janiele Pereira da Silva Santos

Tamires dos Santos Cirilo Diniz.

Alane de Souza Silva

Resumo: 0 presente artigo aborda a prática da aula de campo como metodologia de ensino para a geografia física, instrumento esse que deve ser utilizado como forma atrativa para os discentes. A aula de campo traz consigo subsídios para um significativo desenvolvimento no processo de ensino e aprendizagem, contribuindo para a aquisição de conhecimentos a partir da assimilação dos conteúdos vistos em sala de aula associando com o campo, possibilitando a progressão da disciplina de Geografia juntamente com a inovação de práticas metodológicas de cunho pedagógico concedido pelo educador. Partindo destes pressupostos, o principal objetivo é discutir a importância da aula de campo quanto uma ferramenta metodológica nas aulas de Geografia no ensino fundamental e médio. Para a elaboração desse estudo, recorremos a experiências pessoais adquiridas durante uma aula de campo, que almeja promover discussões acerca da temática, favorecendo o ensino da Geografia mediante a aplicação de um método dinâmico e compreensivo. Os principais autores que embasam esse trabalho foram: Bueno (2009), Cordeiro e Oliveira (2011), Rodrigues e Otaviano (2001), nos discursos sobre a aula de campo como contribuinte para uma melhor compreensão dos conteúdos geográficos e sua importância para o aprendizado, em que o professor deve basear-se na realidade do discente. Através dos resultados de uma aula de campo realizada pela turma acadêmica do Curso de Geografia da UEPB, Campus III, e do posicionamento de diversos teóricos, espera-se que seja notado o reconhecimento que essa metodologia apresenta para o alunado na sua inserção no meio em está inserido.

Palavras-chave: Aula de Campo, Metodologia de Ensino, Geografia Física, Conhecimento. 


\section{INTRODUÇÃO}

A Geografia desde seus primórdios dá uma significativa importância aos meios rurais e urbanos, havendose uma divisão no modo relacionado a cada campo de estudo. A Geografia tem como suas áreas de estudos uma diversidade de elementos e existem várias ramificações, como Geografia Política, Geopolítica, Geografia Ambiental, Geografia Crítica entre outras que são de grande relevância para nosso conhecimento tanto teórico como pedagógico. Tradicionalmente temos as chamadas Geografia Física e a Geografia Humana, onde se enquadra todas as geografias. A Geografia Física está relacionada à natureza com o relevo, o clima, a vegetação, o solo e as águas. E a Geografia Humana estuda a relação do homem com o meio que o cerca.

Dentre as metodologias que auxiliam na prática educativa para o ensino de Geografia, ressaltadas por Louzada e Frota Filho (2017, p. 75-84) como: Reálias (objetos e conceitos), Terrário (o mundo em miniatura), Estudo do Meio (análise da própria realidade) e Mapa Mental (visão detalhada e focal), destacamos a Aula de Campo como uma forma do/a aluno/a adquirir novos conhecimentos de maneira mais prazerosa, principalmente no ensino de Geografia para o ensino fundamental e médio. Todavia, a utilização desse método para o ensino da Geografia é uma forma de adquirir o saber.

Essa metodologia de ensino contribui para uma melhor compreensão dos conteúdos ao relacionar a teoria proposta em sala de aula com os estudos e análises práticas da paisagem do ambiente observado, ampliando os seus horizontes geográficos ao ir além dos textos e fotografias do livro didático, e permitindo o desenvolvimento de diversas habilidades nos alunos, tais como identificar, distinguir e ampliar os conhecimentos adquiridos nas instituições de ensino, comparando-a com a realidade do lugar em que os envolvidos estão habituados (CORDEIRO; OLIVEIRA, 2011, p. 3).

0 objetivo deste trabalho visa discutir a importância da aula de campo quanto uma ferramenta metodológica nas aulas de Geografia no ensino fundamental e médio, possibilitando a junção entre teoria exposta em sala de aula e a vivência na prática com a aula de campo; facilitando a percepção dos educandos através do contato com o meio que o cerca; estimulando o alunado a ser um indivíduo crítico e pensante. Zoratto e Hornes (2014) indicam que a aula de campo é uma ferramenta didática que contribui muito na assimilação e ligação entre teoria dada em sala de aula com a observação do campo.

A Geografia é um componente curricular que possibilita o indivíduo a entender o ambiente em que vive. No contexto atual, precisamente no ambiente escolar, a geografia ainda é apresentada por intermédio do ensino tradicional, ou seja, não há vínculo de um determinado assunto com a realidade do alunado, tornando os conteúdos geográficos enfadonhos geralmente apresentados nos livros didáticos, como anuncia os PCNs - Parâmetros Curriculares Nacionais (1998, p. 135), "o ensino de Geografia, de forma geral, é realizado mediante aulas expositivas ou leitura dos textos do livro didático". Quando nos referimos a recurso metodológico, há uma questão muito importante a ser indagada: De que maneira a Aula de Campo torna-se metodologia facilitadora no entendimento dos conteúdos relacionados à Geografia Física?

Tendo em vista a realidade do ensino de geografia nos dias atuais, é necessário pensar numa proposta pedagógica e metodológica onde os discentes entendam e relacionem o que se é argumentado com o que eles veem ao seu redor, possibilitando o relacionamento entre teoria e práxis, ou seja, sala de aula e aula de campo. Isso é uma prática pedagógica, pois não é apenas transmissão de conhecimentos, mas é possível instigar as curiosidades, proporcionar o interesse e desenvolver o pensamento crítico do educando.

\section{METODOLOGIA}

Com o propósito de anunciar perceptivelmente a importância da aula de campo como prática pedagógica para o ensino da geografia, utilizou-se o estudo em uma estratégia qualitativa, através de uma pesquisa de campo ligadamente ao estudo bibliográfico. Partimos da cidade de Guarabira, onde está situada a Universidade Estadual da Paraíba, Campus III, sob a supervisão do professor Leandro Paiva, rumo a uma aula de campo com as turmas do curso de Geografia, graduandos dos turnos tarde e noite, no qual o trajeto seguiu do litoral ao sertão, passando por várias cidades que vão ser especificadas no decorrer dessa pesquisa

O estudo bibliográfico pautou-se nos trabalhos de Rodrigues e Otaviano (2001) e Cordeiro e Oliveira (2011). A pesquisa bibliográfica "trata-se do levantamento de toda a bibliografia já publicada [...]. Sua 
finalidade é colocar o pesquisador em contato direto com tudo aquilo que foi escrito sobre determinado assunto [...]" (MARCONI; LAKATOS, 2011, p. 43-44).

Dessa forma, torna-se inegável que o estudo bibliográfico precisa anteceder o estudo de campo, pois o pesquisador deve ter conhecimento apropriado sobre a temática a ser estudado. Conforme as Diretrizes Curriculares de Geografia para Educação Básica da Secretaria de Estado da Educação do Paraná:

A aula de campo é um importante encaminhamento metodológico para analisar a área em estudo (urbana ou rural), de modo que o aluno poderá diferenciar, por exemplo, paisagem de espaço geográfico. Parte-se de uma realidade local bem delimitada para investigar a sua constituição histórica e realizar comparações com os outros lugares, próximos ou distantes. Assim, a aula de campo jamais será apenas um passeio, porque terá importante papel pedagógico no ensino de Geografia (PARANÁ, 2008, p. 80 e 81).

\section{DESENVOLVIMENTO}

No que se refere à Geografia Física e a aula de campo, percebe-se que a Geografia Física estuda o meio físico do nosso planeta e seus principais elementos que os estruturam, como: relevo, águas, climas, fauna, vegetação e solo. Essa área da geografia é de suma importância para o estudo da natureza e relevante para o homem compreender o meio em que vive, procurando entender o ambiente e propiciar a compreensão direta quanto à caraterísticas locais. Para a geografia, o espaço social se tornou fonte de estudo, uma nova vertente para deixá-la dinâmica, ao menos nessa disciplina em sala de aula.

0 estudo do meio retratado acima se completa com base ao emprego da utilização do campo como metodologia de ensino, com o principal intuito de despertar a motivação e o interesse do discente em entender os conteúdos da Geografia Física que são vistos em sala de aula. Através desta prática, o educando intercala a assimilação dos conteúdos de sala com a observação em campo, como pode ser constatado no discurso de Cordeiro e Oliveira (2011, p.103) que

Dentre os recursos para auxiliar no ensino de Geografia, as aulas de campo aparecem como um instrumento eficiente para o estabelecimento de uma nova perspectiva na relação aluno/aprendizagem, pois o aluno passa a "ver" a Geografia em vez de "ler" a Geografia, permitindo assim, uma maior compreensão do espaço geográfico.

Dessa forma, o trabalho em sala de aula com a aula de campo tem o significativo valor educacional interligado ao aprendizado do alunado através desta prática pedagógica. Conforme Rodrigues e Otaviano (2001, p. 35), "o contato com a realidade dará ao aluno uma nova dimensão dos assuntos tratados nas aulas o que, se bem programado e orientado, servirá entre as tantas finalidades, estimular o estudo articulado com as diferentes disciplinas".

As práticas de aula de campo são essenciais para os discentes no curso de formação de professores, principalmente para quem almeja ser um profissional na área da educação, pois esse procedimento configura como um elemento chave. A utilização deste recurso deve ser feita com muita atenção para que não seja entendida como um momento de lazer, mas sim uma forma de aprendizado.

Desta maneira, para a realização de uma aula de campo, o docente deve conter um roteiro atendendo alguns requisitos necessários, como: Transporte; Acomodação ao chegar ao destino final; Conteúdo programado do que será feito em campo; Materiais como mapa, se forem necessário à utilização; Conhecimento prévio do trajeto a ser percorrido; Todo conteúdo trabalhado em campo deve conter ligação com o trabalhado em sala.

De acordo com Cordeiro e Oliveira (2011), para que haja um melhor resultado no desenvolvimento do conhecimento e da formação do discente é de fundamental importância à utilização de novas metodologias e recursos de ensino para que, desta forma, o aprendizado não seja atribuído a algo chato, monótono, cansativo, devido ao fato de se colocar distante da realidade do aluno. (CORDEIRO; OLIVEIRA, 2011.p.105)

Fica evidente a significação da aula de campo por proporcionar uma vasta contribuição para o aprendizado de ambas as partes envolvidas, sejam educadores e/ou aprendizes. Este recurso é muito significativo para o entendimento do lado físico da Geografia. Os subsídios deste recurso didático no componente curricular de Geografia ficarão ainda mais visíveis a partir do discursão da atividade a seguir. 


\section{RESULTADOS E DISCUSSÃO}

Na finalidade de aplicar as aprendizagens adquiridas em sala de aula mediante uma atividade de campo, a equipe composta por estudantes de graduação em Geografia da UEPB, Campus III, professor e motoristas, partiu da cidade de Guarabira, localizada no Estado da Paraíba, com destino a Patos - PB, passando por João Pessoa - PB e Cabedelo, sua Região Metropolitana, ocorrendo em dois dias: 27 e 28 de abril de 2018. Foi possível observar os aspectos físicos das respectivas cidades.

O momento da atividade de campo caracterizou-se a prática empírica, onde os/as alunos/as tiveram o contato direto com o objeto de estudo, podendo observar e investigar o mesmo. As localidades visitadas e as respectivas atividades desenvolvidas serão apresentadas a seguir.

Guarabira está localizada na região do agreste paraibano, mais conhecida por Rainha do Brejo, predomina o clima quente e úmido, sendo a nona cidade mais populosa da Paraíba. Em 1884, com a implantação da linha férrea, intensificou o comércio de produtos, principalmente algodão e sisal. (NASCIMENTO; MARQUES; SANTOS, 2016). E isso levou mais a frente sua emancipação política, a dinâmica do comercial se ampliaram e sua urbanização teve um forte crescimento. Os serviços que a cidade passa a oferecer a população também aumentaram, passando a ser um centro de comércio das cidades ao seu entorno, sua localização foi algo que favoreceu o seu desenvolvimento.

Guarabira atualmente é referência em termos estruturais de bens e serviços, disponibilizando comércio, saúde, educação para maioria das cidades vizinhas, pela qual recorrem à cidade que conta com algumas empresas, movimentando a economia e gerando emprego. Tem um Hospital Regional e uma UPA (Unidade de Pronto Atendimento), empresas como da Guaraves que gera muitos empregos em toda a região, redes de transporte dentro do estado e até pra fora.

Passando por pelo município de Mari, foi observado as plantações de macaxeira e vários outros produtos agrícolas, acampamentos de pessoas sem terras que ocupam o local. Já em Sapé, a cultivação do abacaxi é mais predominante no município, tendo o clima adequado para sua cultivação. No entanto, para sua plantação, é preciso capital para investir na sua produção que dura em média dezoito meses até sua colheita (CARVALHO, 1985). Com desenvolvimento em tecnologia e os sistemas de irrigação, o tempo de produção varia. Outro fator que tem bastante influência é o uso de agrotóxicos, levando em consideração o preparo da terra.

Atualmente, o uso de agrotóxicos nas plantações é cada vez mais intenso, levando em conta que alguns são proibidos pelas entidades responsáveis, além de trazer várias doenças para as pessoas que trabalham com o produto sem proteção, fazendo muito mal a quem consome o produto e também poluem os lenções freáticos, pois em período chuvosos, são levados para os reservatórios de água e até mesmo para o consumo, trazendo sérios riscos para a população.

Passamos por João Pessoa, capital paraibana, que foi fundada em 1845. No passado era agrária, através de atividades agrícolas como a cana de açúcar nos engenhos, que com o passar do tempo foi substituída por usinas. Surgiu também serviços como abastecimento de água e fornecimento de energia, as ferrovias teve papel fundamental no desenvolvimento do comércio e na circulação de pessoas (OLIVEIRA; SILVA, 2016). A cidade surge às margens do rio com o intuito de garantir água para o consumo e as necessidades básicas da população, assim também como o desenvolvimento das fábricas, pela qual a cidade passa a receber imigrantes do campo em busca de empregos e a urbanização começa a ter um ritmo mais acelerado.

Atualmente a capital paraibana se destaca em indústrias alimentícias, onde o comércio movimenta muito a economia local e do estado inteiro. Os pontos turísticos da cidade é algo que atrai gente do Brasil inteiro, com suas belas praias e monumentos históricos da cidade, sua beleza e sua riqueza é exuberante, vem crescendo bastante principalmente sua urbanização. A construção civil é um ramo que tem investido muito capital, e também gerado muitos empregos no estado inteiro, a maioria dos trabalhadores são de fora da capital. Conta também com frota de transporte coletivo dentro da cidade, e outras empresas para fora de João Pessoa, que circulam no estado, as áreas de lazer como shopping, a educação é uma referência para a maioria da população do estado, como Universidade Federal da Paraíba, entre outras.

o porto de Cabedelo que exportados e importados muitos produtos pelo rio Paraíba, movimentando a economia e gerando renda, conhecemos um pouco de sua história contada por um senhor que trabalha no local. Além disso, visitamos Forte de Santa Catarina conhecido como Fortaleza de Santa Catarina, que ganha esse nome por causa da duquesa Bragança. A fortaleza localizada a margem do rio Paraíba, que impedia a entrada dos holandeses, tornando-se um local com muitas histórias e sendo ponto turístico 
muito visitado no Estado. Foi um local de muitas batalhas e sofrimentos, dentro do Forte estrategicamente tem um poço indispensável para a sobrevivência, em que é um lugar com várias saídas que davam para o rio, grande tática para possível rota de fuga.

Seguimos rumo à Praia do Jacaré que é muito conhecida por sua beleza natural, principalmente o pôr do sol. 0 local recebe muitos turistas em toda época do ano, no qual o comércio e o artesanato são locais, com passeios de barcos no rio, que é largo, e as margens nos mangues observam-se os caranguejos. A noite tem shows culturais, a culinária também ganha destaque por sua diversidade e sabor.

A cidade de Patos, localizado no Sertão Paraibano, é uma cidade desenvolvida, sua urbanização ainda está em crescimento, em que o forte comércio gera emprego e movimenta a economia local e cidades e municípios limítrofes. A cidade de Patos tem ruas largas e asfaltadas com clima semiárido quente e seco. Durante o dia, as temperaturas sobem e a noite elas caiem. Patos é a terceira cidade com maior PIB da Paraíba, exporta para várias outras cidades produtos alimentícios e industriais, calçados, minérios não metálicos (NASCIMENTO; LIRA, 2013). A cidade conta com várias agências bancárias e com grandes redes logísticas, a educação ganha destaque a Universidade Estadual da Paraíba - UEPB, onde conta com vários cursos, e atrai estudantes de muitas cidades.

Contudo a cidade tem alguns problemas referentes à sua estrutura e sua urbanização acelerada, em que o sistema de tratamento de saneamento básico que atinge a maioria dos bairros. Não tem Estação de Tratamento de Esgoto (ETE) para atender as necessidades da população, impossibilitando a instalação de grandes empresas (NASCIMENTO; LIRA, 2013). A população de Patos é desenvolvida, no entanto, sua urbanização precisa de mais planejamento.

Por fim, visitamos Taperoá uma cidade pequena do sertão paraibano com poucos habitantes, apresentando clima seco e quente, que ficou muito conhecida por ser retratado o filme Auto da Compadecida, escrita por Ariano Suassuna.

Pode-se notar as formas de relevo e as mudanças paisagísticas, a vegetação no período de chuvas, mudando totalmente o cenário geográfico. Na subida da Serra do Teixeira, a vista é a paisagem, sendo a vegetação bem escassa de fácil evaporação de água. Ao término do período chuvoso, a mesma fica seca por ser frágil. Já no período de seca, a vegetação fica escura com galhos secos, o clima fica mais quente, apesar de ser quente de dia e a noite bem mais frio, por causa da altitude.

Como mostra as figuras abaixo (Figura 02), há modificações na vegetação, nos recursos hídricos e na coloração da própria rocha. A análise do espaço geográfico, suas percepções com relação relevo hidrogeografia e vegetação bem visíveis nas paisagens.

Figura 01: Mudanças na vegetação da Pedra do Tendó, em Teixeira - PB.
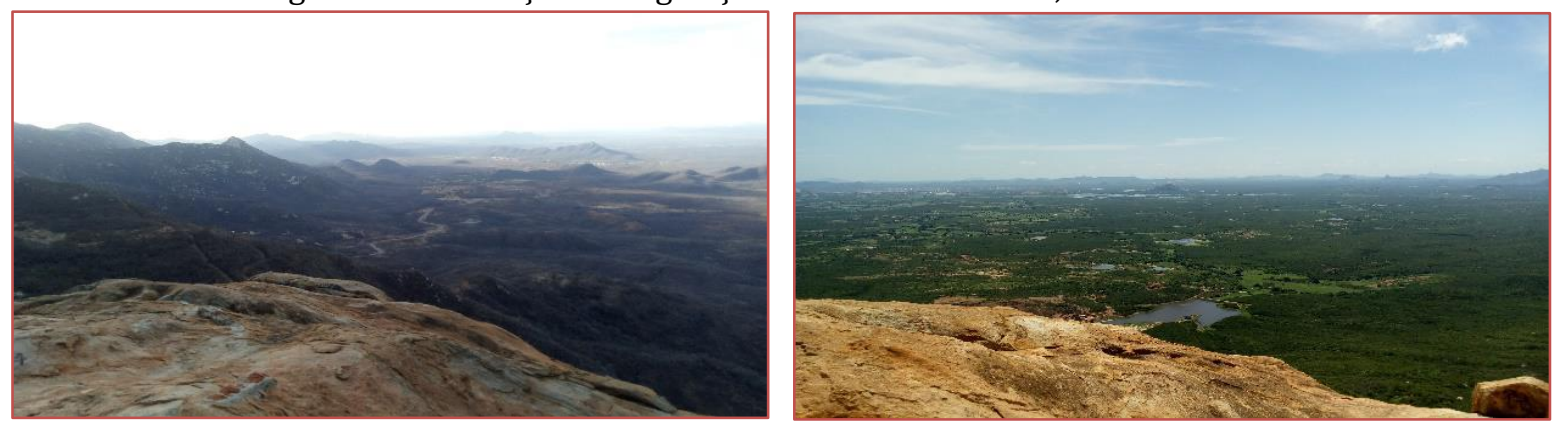

Fonte: Arquivo pessoal dos autores, 2018.

Tudo fica mais compreensível quando se há prática no processo de ensino e aprendizagem, sobretudo em uma aula de campo, assunto na qual está sendo abordade nesse trabalho, deixando claro sua significativa importância na obtenção de conhecimentos, associando as teorias estudadas em sala de aula.

As viagens são alternativas de proporcionar a integração e socialização entre professor e estudantes, além de favorecer o entendimento sobre os referidos conteúdos inerentes a Geografia, permitindo estimular a observação da paisagem local. 
A aula de campo nunca vai ser tempo perdido, nem só passeio, pois serve de grande auxílio na formação do discente, concedendo ter uma base teórica melhor, possuir argumentos delimitando seus pontos de vista e compreender a Geografia, principalmente na área de Geografia Física que é muito complexa.

A educação escolar tem todo um traçado, particularmente em relação ao livro didático que já tem todo conteúdo programado, parecendo uma ferramenta completa capaz de propiciar um aprendizado simples e eficaz. Porém, não deve ser trabalhada sozinha, pois precisa está conectada a novos recursos metodológicos. Com a aula de campo é possível aproximar o aluno aos conteúdos de geografia de forma significante.

Enfim, a aula de campo pode oferecer momentos únicos para os envolvidos no desenvolvimento educacional, pois se fazem presente no processo de compreensão dos elementos do espaço geográfico.

A partir deste relato de aula de campo fica evidente a intensidade desse meio didático para fins de aprendizado. Para Matheus (2007, p. 142), “[...] é nessa perspectiva que considero importante sair do espaço escolar mais formal, com papeis definidos e cadeiras ordenadas, para um local que nos permita [...] proporcionar um novo olhar ao que já está dado".

\section{CONSIDERAÇõES FINAIS}

A aula de campo é indispensável no processo de aprendizagem, pois possibilita ver os conteúdos na prática, além de ficar uma aula mais atrativa que o habitual, garantindo muitas fontes de conhecimentos ao mesmo tempo fazer relações com o cotidiano.

Entretanto deve ser planejado, e assim fazer uma ponte entre conteúdos abordados em sala, principalmente na Geografia Física que é considerada um assunto complicado se de entender, pois abrange vários elementos, dificultando um pouco a assimilação.

O intuito da aula de campo é proporcionar aquilo que não pode ser visto em sala de aula, visto que na Geografia Física e o estudo da natureza são concedidos o entendimento em campo. Com essa metodologia, pode-se observar, tendo um contato maior com determinados fenômenos naturais, as formas de relevo, a vegetação entre outros recursos naturais, recursos hídricos, mudança na paisagem, fatores climáticos, tipos de solos etc.

Tendo em vista as dificuldades do alunado quanto à absorção dos conteúdos de Geografia Física, a aula de campo se mostrou, metodologicamente, eficaz. No entanto, precisa haver um planejamento anteriormente, enriquecendo os conceitos e tornando a disciplina o mais real possível. Quando não há um planejamento corre-se o risco de se tornar apenas um passeio.

É fundamental considerarmos as dificuldades existentes na prática da docência no ensino de Geografia Física. Portanto, faz-se necessário o educador procurar inovar as aulas através de renovações metodológicas. A utilização do meio natural como obtenção de aprendizado é enriquecedor para a construção intelectual do aluno, estimulador para o despertar da curiosidade e pelo entendimento do meio que o cerca.

Enfim, é primordial explorarmos nosso território, procurando entender como ele funciona e a aula de campo proporciona todo esse entendimento. Ao empregar este método como recurso didático, é notória a significação em assegurar um olhar mais amplo acerca da Geografia, atuando como facilitador do trabalho pedagógico, estabelecendo mais significativo os conteúdos vistos com os discentes em sala de aula.

\section{REFERÊNCIAS}

[1] BRASIL. Secretaria de Educação Fundamental. Parâmetros Curriculares Nacionais: geografia/ Secretaria de Educação Fundamental. Brasília : MEC/ SEF, 1998.

[2] BUENO, M. A. A importância do estudo do meio na prática de ensino em geografia física. Boletim Goiano de Geografia, Goiânia, GO, v. $29, \quad$ n.2, $2009 . \quad$ Disponível <http://www.revistas.ufg.br/index.php/bgg/article/view/9028>. Acesso em: 05 maio 2018.

[3] CARVALHO, M. L. G.. A cultura do abacaxi no município de sapé um exemplo de modernização. 1985.

[4] CORDEIRO, J. M. P.; OLIVEIRA, A. G. de. A aula de campo em geografia e suas contribuições para o processo de ensino- aprendizagem na escola. Geografia (Londrina), Londrina, v. 20, n. 2, p. 099-114, maio/ago.2011. Disponível em: <http://www.uel.br/index.php/geografia,. Acesso em: 05 maio 2018. 
[5] LOUZADA, C. de 0.; FROTA FILHO, A. B. Metodologias para o ensino de Geografia Física. Geosaberes, Fortaleza, v. 8, n. 14, p. 75-84, jan./abr., 2017.

[6] MARCONI, M. de A.; LAKATOS, E. M. Metodologia do trabalho científico: procedimentos básicos, pesquisa bibliográfica, projeto e relatório, publicações e trabalhos científicos. 7. ed. - 6. reimpr. São Paulo: Atlas: 2011.

[7] MATHEUS, E. H. C. O que há por trás de uma panela? Uma atividade de campo como trajetória a um olhar geográfico. In: REGO, N; CASTROGIOVANNE, A. C; KSERCHER, N. A. Geografia: práticas pedagógicas para o ensino médio. Porto Alegre: Artmed, 2007.

[8] NASCIMENTO, J. R. F. do; MARQUES, A. C. dos S.; SANTOS, R. F. P. dos. Uma análise sobre os circuitos da economia urbana em Guarabira-PB. São Luiz, 2016.

[9] NASCIMENTO, P. J. A.; LIRA, R. T. M. Artigo de revisão. Uma abordagem sobre o desenvolvimento urbano da cidade Patos, Estado da Paraíba. RBDGP (Pombal - Paraíba, Brasil), v.1, n2,p. 10-16, abr-jun., 2013.

[10] OLIVEIRA, M. H. de S. G.; SILVA, J. C. da. Um olhar geográfico sobre a história de João Pessoa. São Luiz, 2016.

[11] PARANÁ. Diretrizes Curriculares da Educação Básica: Ensino Fundamental e Médio. Secretaria de Educação do Estado do Paraná, Curitiba: 2008.

[12] RODRIGUES, A. B.; OTAVIANO, C. A. Guia Metodológico de Trabalho de Campo em geografia. Geografia, Londrina, v. 10,p. 35-43, jan./jun.2001.

[13] ZORATTO, F. M. M.; HORNES, K. L. Aula de campo como instrumento didático-pedagógico para o ensino de geografia. In: Os desafios da escola pública paranaense na perspectiva do professor PDE. Paraná, 2014. v. 1. Cadernos PDE. 


\title{
Capítulo 11
}

\section{Uso de dispositivos móveis e aplicativos (APPS) no ensino da química: Revisão sistemática da literatura}

\author{
Fernanda Marcondes de Paiva
}

Resumo:. Este trabalho apresenta uma revisão da literatura acerca do uso de dispositivos móveis e aplicativos (apps) como ferramentas de ensino-aprendizagem da Química a partir de publicações da área educacional no período de 2010 a 2018, perfazendo 75 pesquisas, dentre artigos, trabalhos de conclusão de curso, dissertações e teses. A produção nesta área tem ocupado lugar de destaque na literatura acadêmica, constituindo tema de crescente interesse nas instituições de ensino. A análise das pesquisas selecionadas permitiu identificar que os dispositivos móveis e apps estão sendo utilizados largamente como auxílio à educação em Química. Os resultados também apontaram para a necessidade de mais pesquisas que verifiquem a adequabilidade dessas ferramentas como recursos didáticos, assim como sua compatibilidade com as necessidades e expectativas de professores e alunos.

Palavras-chave: Dispositivos móveis; Aplicativos; Ensino. Química. 


\section{INTRODUÇÃO}

A Rede Mundial de Computadores, muito além de ser entendida como uma simples conexão entre máquinas, passou a ser reconhecida como poderosa ferramenta de ensino, pesquisa e transformação social. Nesse cenário, os dispositivos móveis - tais como tablets e smartphones - e os aplicativos (apps) têm despontado como protagonistas na garantia de acesso e disseminação de conhecimento, minimizando sobremaneira as limitações espaço-temporais e possibilitando o emprego emergente da aprendizagem com mobilidade, o "m-learning" (JACON, 2014).

Os diferentes dispositivos computacionais conectados entre si transformaram a sociedade em que vivemos. Os tablets e smartphones atuais agregaram funcionalidades antes específicas dos computadores de mesa e, atualmente, encontram-se em franca expansão, permitindo sua inserção em diversos setores sociais, dentre eles, o educacional (JACON, 2014).

Compreendidos como condição essencial ao indivíduo contemporâneo, o acesso à informação, a conexão e a mobilidade tornaram-se imprescindíveis no contexto de mundo globalizado. 0 significativo avanço no uso dos recursos tecnológicos permite imaginar que, muito provavelmente, está em curso um novo paradigma na área das Tecnologias da Informação e Comunicação (TIC), que oportuniza o emprego cada vez maior da aprendizagem com mobilidade (SACCOL; SCHLEMMER; BARBOSA, 2011).

Parece natural, portanto, que nos dias atuais exista um apelo cada vez maior para que os dispositivos móveis sejam incluídos na sala de aula com o intuito de melhorar o aprendizado e as práticas de ensino. Nesse sentido, essa tecnologia móvel - associada ao uso de apps concebidos exclusivamente para a educação - representa significativa inovação nas atividades pedagógicas, ampliando os espaços-tempos de aprendizagem para além das salas de aula (JACON, 2014).

A mobilidade e a ubiquidade proporcionadas pelos smartphones e tablets, aliadas à possibilidade de implementação de aplicativos educacionais gratuitos e de fácil utilização, possibilitam uma gama variada de oportunidades aos alunos, num contexto em que o processo de ensino-aprendizagem se torna mais significativo (NICHELE; SCHLEMMER, 2014; SILVA, 2017).

Locatelli, Zoch e Trentin (2015) defendem que a Química é uma ciência experimental com alguns conteúdos abstratos e de difícil entendimento e visualização. Assim, a utilização das TIC pode auxiliar na compreensão e aprendizagem dos alunos. Dentro das ferramentas tecnológicas disponíveis, os dispositivos móveis e aplicativos permitem uma possibilidade a mais, um meio de aprendizagem com interação entre os estudantes, que podem incrementar o ensino dentro e fora da sala de aula, por meio de jogos, exercícios, vídeos, e-books e acesso a pesquisas e bancos de dados (NICHELE; SCHLEMMER, 2014).

Os dispositivos móveis e os aplicativos educacionais podem se destacar nos processos de ensino e aprendizagem da Química por proporcionarem melhores simulações e modelos, permitindo a visualização e a manipulação virtual de estruturas químicas e o acesso a uma infinidade de tabelas e informações químicas, entre outras possibilidades. Desse modo, o desenvolvimento das tecnologias digitais e a proliferação das redes interativas tendem a colocar o ensino da Química diante de um caminho sem volta, pois já não somos como antes (BENITE; BENITE; SILVA FILHO, 2011).

Dentro dessa perspectiva, buscou-se neste artigo revisar a literatura disponível na rede mundial de computadores visando identificar, selecionar e analisar publicações acerca do uso de dispositivos móveis e aplicativos na educação em Química, bem como responder às seguintes questões norteadoras:

- Nos estudos publicados, os dispositivos móveis e suas aplicações têm sido utilizados como ferramentas auxiliares no processo ensino-aprendizagem da Química?

- Que tipos de estudos estão sendo feitos a partir da relação dispositivos móveis, aplicativos e educação em Química?

- Quais aspectos ainda não foram explorados ou necessitam de maior aprofundamento?

De acordo com Pereira e Bachion (2006), a revisão da literatura - também conhecida como revisão bibliográfica ou contextualização - é fundamental para a prática baseada em evidência, uma vez que condensa grande quantidade de informações num único estudo, tornando fácil o acesso às informações sobre o tema, além de servir de base científica para formulação de guias de condutas. 
Silva e Porto (2016) sintetizam que a revisão literária deve indicar o "estado da arte" do tema proposto, apresentando texto lógico e fluido, em que a leitura seja corrente e não pareça a simples justaposição de textos. Segundo os autores,

A revisão da literatura tem importância fundamental para a produção científica, pois uma das características do conhecimento é a acumulação. Tudo o que se produz em ciência serve de base para novas descobertas. E essa característica, sem dúvida, foi decisiva para o desenvolvimento da humanidade. (SILVA; PORTO, 2019, p. 68).

Partindo desse pressuposto, o presente artigo revisa sistematicamente a literatura acerca do "Uso de dispositivos móveis e aplicativos (apps) no ensino da Química", identificando quais perspectivas, dimensões e entendimentos vêm sendo destacados e privilegiados pela produção acadêmica brasileira nos últimos anos.

\section{FUNDAMENTAÇÃO TEÓRICA}

\subsection{DISPOSITIVOS MÓVEIS E APLICATIVOS: POSSIBILIDADES NA SALA DE AULA}

De acordo com a 29a Pesquisa Anual de Administração e Uso de Tecnologia da Informação nas Empresas, realizada pela Fundação Getúlio Vargas (FGV), o Brasil superou a marca de um smartphone por habitante e hoje conta com 220 milhões de celulares inteligentes ativos (MEIRELLES, 2018).

Os dispositivos móveis - com conexão sem fio (wireless) e interface sensível ao toque (touch screen) associados a diferentes aplicativos, têm proporcionado mudanças na maneira de nos relacionarmos com a informação e produzirmos conhecimento, apresentando significativo potencial para transformar o processo ensino-aprendizagem (NICHELE; SCHLEMMER, 2014).

Tais ferramentas oferecem a professores e alunos mobilidade e interface fácil de usar, podendo assim, contribuir para a elaboração de diferentes estratégias educacionais, ampliando as possibilidades de ação e interação entre sujeitos, sujeitos e meio (incluindo os próprios dispositivos, os aplicativos e o ambiente local geográfico onde os sujeitos se encontram), bem como os processos de colaboração e cooperação (NICHELE; SCHLEMMER, 2014).

A disseminação dos dispositivos móveis tem impulsionado o desenvolvimento de novos aplicativos com potencial para incrementar o aprendizado dentro e fora da sala de aula. Há diversos tipos de apps disponíveis, tais como jogos, mídias sociais, livros, revistas, bem como softwares específicos para a educação, para a navegação na internet e para o gerenciamento e a organização de atividades e processos (NICHELE; SCHLEMMER, 2014).

No contexto escolar, a flexibilidade espacial e temporal promovida pelos dispositivos móveis confere novas possibilidades à educação, como o prolongamento das atividades escolares para fora dos limites físicos da escola, além da descentralização do processo ensino-aprendizagem, na qual o docente deixa de ser a única fonte de informação (JACON, 2014).

Entre outras possibilidades, essas características ampliam o desenvolvimento do mobile learning, que é uma modalidade educacional em que processos de aprendizagem ocorrem com o uso de dispositivos móveis conectados a redes de comunicação sem fio, e tem como característica fundamental a mobilidade dos aprendizes, que podem estar distantes uns dos outros e também dos espaços formais de educação. Essa mobilidade, além de física e temporal, é também tecnológica, conceitual e sociointeracional (SACCOL; SCHLEMMER; BARBOSA, 2011).

A melhoria da tecnologia dos computadores portáteis e dos telefones móveis, tornou indispensável o seu uso no cotidiano de qualquer cidadão e o seu emprego - como ferramenta de ensino-aprendizagem - tem sido elemento de discussão e análise de diversas propostas educacionais (NICHELE; SCHLEMMER, 2014; SILVA, 2017).

É comum encontrarmos instituições de ensino e, principalmente, professores avessos à utilização de tecnologias da informação e comunicação pelos alunos em sala de aula. Em geral, essas TIC não são vistas como recursos positivos ao processo pedagógico. De acordo com Reinaldo et al (2016), existe uma interpretação errônea do educador, que vê tais ferramentas como ameaça à sua autoridade. Daí, o fato de muitas escolas não envidarem esforços para incorporá-las em suas práticas pedagógicas. 
Todavia, Giordan (2008) destaca que as tecnologias são instrumentos que exercem funções mediadoras importantes nas atividades humanas, pois dispõem de atributos exclusivos que possibilitam melhor relacionamento do sujeito com o mundo. A inserção de dispositivos móveis na escola representa uma realidade que não pode ser ignorada. De acordo com Voss et al (2013), o crescimento das tecnologias de telefonia móvel aumentou a mobilidade dos usuários e criou novas possibilidades, entre elas a aplicação da computação móvel no contexto educacional.

Utilizar a tecnologia móvel como ferramenta de aprendizagem a partir de processos de mobilidade e ubiquidade implica abrir-se às potencialidades que tais dispositivos oferecem. Esse processo exigirá dos docentes ampliação do senso de observação para perceber tais possibilidades, assim como maior autonomia e protagonismo no processo educacional (GRASEL, 2013).

Conforme nos mostra Saccol, Schlemmer e Barbosa (2011), o conhecimento está disponível e acessível em múltiplas plataformas digitais e, por intermédio dos dispositivos móveis, os sujeitos poderão acessá-lo de maneira autônoma a qualquer hora, em qualquer lugar. Esta é uma realidade que as instituições escolares não podem mais ignorar.

A incorporação das TIC no ambiente escolar proporciona o enriquecimento na educação em Ciências, tornando o ensino mais interessante, autêntico e relevante. Além de permitir momentos de interação e colaboração, a tecnologia de informação e comunicação melhora o empenho dos estudantes, auxiliando na aprendizagem e nos resultados das avaliações (MARTINHO; POMBO, 2009).

Ademais, é extremamente importante buscar metodologias alternativas que auxiliem no processo de aprendizado dos alunos, principalmente porque a geração que está atualmente nas escolas é a chamada Geração Z (de zapear/zap), que se caracteriza por ser dinâmica e inovadora. Segundo Siqueira (2012), a Geração Z é representada por jovens que estão sempre conectados à internet e fazem tudo de maneira muito rápida, convivem com a tecnologia diariamente e realizam diversas tarefas ao mesmo tempo.

São conhecidos por serem nativos digitais, muito familiarizadas com a internet, com o compartilhamento de arquivos e com os telefones móveis, não apenas acessando a rede em suas casas, mas também pelo celular. Suas principais características são a compreensão da tecnologia, a capacidade de exercer multitarefas, a abertura social às tecnologias, a velocidade, a impaciência e a interatividade (MEIR, 2017).

Esses adolescentes da Geração Z necessitam de novos métodos de ensino, atualizados e voltados aos seus interesses. Não há como seguir as mesmas metodologias. A necessidade de inovação é urgente.

\section{METODOLOGIA}

Para a consecução do presente trabalho, foi realizada uma revisão sistemática da literatura baseada em estudos empíricos nacionais publicados no período de 2010 a 2018 e indexados na base de dados do Google Acadêmico e Portal Capes.

De acordo com Sousa, Silva e Carvalho (2010, p. 2), a revisão da literatura

é uma síntese rigorosa de todas as pesquisas relacionadas a uma questão específica, enfocando primordialmente estudos experimentais. Difere-se de outros métodos de revisão, pois busca superar possíveis vieses em cada uma das etapas, seguindo um método rigoroso de busca e seleção de pesquisas; avaliação de relevância e validade dos estudos encontrados; coleta, síntese e interpretação dos dados oriundos da pesquisa.

A pesquisa centrou-se em artigos, trabalhos de conclusão de curso, dissertações e teses que apresentavam em seu título, palavras-chave ou resumo os descritores 'dispositivos móveis', 'aplicativos' e 'ensino da Química'. Seguindo o que preconiza Bernardo, Nobre e Jatene (2004), após a definição dos descritores, efetuou-se entre eles combinações usando o operador booleano AND, o que permitiu localizar documentos que continham ambos os assuntos simultaneamente: aplicativos AND ensino da Química e dispositivos móveis AND ensino da Química. 
Ademais, com o objetivo de atingir o maior número de trabalhos sobre o tema, também foram utilizados nas buscas termos e expressões semanticamente similares aos descritores definidos (Quadro 1).

Quadro 1 - Descritores e termos semanticamente similares utilizados nas buscas.

\begin{tabular}{|l|l|}
\hline \multicolumn{1}{|c|}{ Descritores } & \multicolumn{1}{c|}{ Termos similares } \\
\hline Aplicativos & Apps, aplicações móveis, softwares, programas \\
\hline Dispositivos móveis & Celulares, smartphones, tablets, tecnologias móveis \\
\hline Ensino da Química & $\begin{array}{l}\text { Educação em(da) Química, ensino-aprendizagem da Química, estudo da } \\
\text { Química, aprendizagem da(em) Química, aprendizado da(em) Química, } \\
\text { obtenção de conhecimento químicos }\end{array}$ \\
\hline
\end{tabular}

Fonte: Autora (2019).

Considerando que numa revisão sistemática da literatura deve-se determinar inicialmente os critérios de inclusão e exclusão de trabalhos (LOPES, 2002), estabeleceu-se nesta pesquisa os seguintes parâmetros delimitadores: estar disponível no Portal CAPES ou Google Acadêmico, apresentar estudos empíricos que abordam a utilização de dispositivos móveis e aplicativos na educação em Química e ter sido publicado em Língua Portuguesa no período de janeiro de 2010 a dezembro de 2018 (Quadro 2).

Quadro 2 - Fatores de Inclusão e Exclusão de trabalhos.

\begin{tabular}{|l|l|}
\multicolumn{2}{|c|}{ Fatores de inclusão } \\
$\begin{array}{l}\text { Trabalhos disponíveis no Portal CAPES e Google } \\
\text { Acadêmico }\end{array}$ & Trabalhos disponíveis em outras bases de dados \\
\hline $\begin{array}{l}\text { Trabalhos acerca da utilização de dispositivos } \\
\text { móveis e aplicativos no ensino da Química }\end{array}$ & $\begin{array}{l}\text { Trabalhos acerca de dispositivos móveis e apps em } \\
\text { contextos educacionais não afetos à Química }\end{array}$ \\
\hline Estudos empíricos & Estudos teóricos \\
\hline Trabalhos escritos em Língua Portuguesa & Trabalhos escritos em outros idiomas \\
\hline Trabalhos publicados entre os anos 2010 a 2018 & Publicações anteriores a 2010 \\
\hline
\end{tabular}

Fonte: Autora (2019).

A buscas realizadas resultaram em 91 trabalhos, dos quais 58 estavam disponíveis no Google Acadêmico e 33 no Portal CAPES. Preliminarmente, realizou-se a análise dos resumos, o que possibilitou a retirada de estudos teóricos, repetidos e de revisão bibliográfica, totalizando 75 pesquisas. Na sequência, com base no exame detalhado dos trabalhos selecionados, foram produzidas categorias sobre as características e os conteúdos abordados (ano de publicação, tipo de pesquisa, área de estudo e finalidade do trabalho) que se encontram pormenorizadas a seguir.

\section{RESULTADOS}

Conforme os critérios estabelecidos pela pesquisadora, a busca pelos estudos que abordaram a temática "Dispositivos móveis e aplicativos (apps) no ensino da Química" abrangeu o período de janeiro de 2010 a junho de 2019 (Figura 1).

Figura 1 - Distribuição dos estudos por ano de publicação.

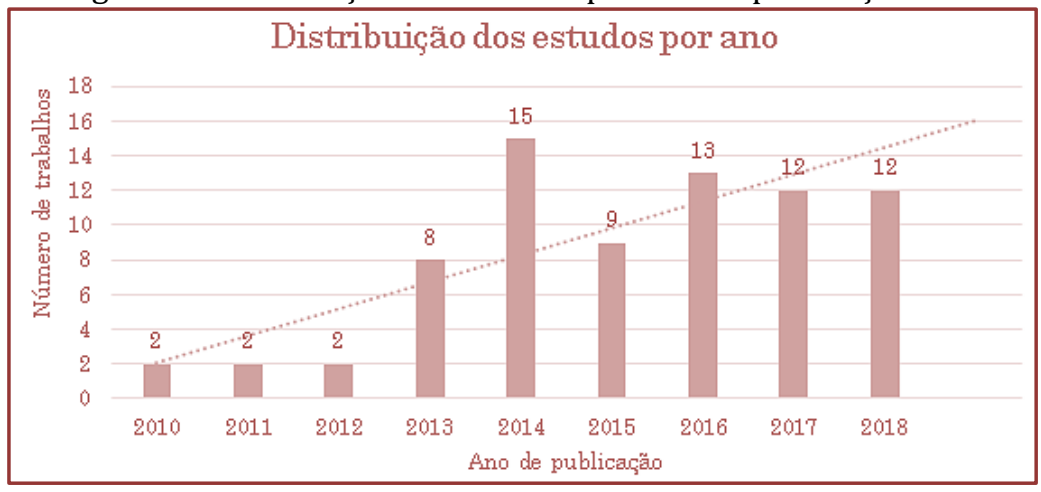

Fonte: Autora (2019). 
A análise do período de publicação dos trabalhos permitiu identificar a evolução cronológica da temática no universo acadêmico nos últimos anos. Observou-se um percentual menor de trabalhos entre os anos de 2010 e 2012, assim como um incremento de mais de 80\% no ano de 2014 em comparação a 2013. No período de 2016 e 2018, verificou-se o maior percentual de pesquisas, com quase $50 \%$ de toda a produção analisado. Tais dados revelam, sobretudo, o crescente interesse dos pesquisadores pelas potencialidades do uso de dispositivos móveis e suas aplicações na educação em Química.

Quanto aos tipos de pesquisas publicadas, constatou-se que, do total de 75 trabalhos mapeados, seis foram trabalhos de conclusão de curso, três dissertações de mestrado e uma tese de doutorado. Os demais trabalhos foram artigos publicados em periódicos, congressos e seminários (Tabela 1).

Tabela 1 - Tipos de trabalhos publicados.

\begin{tabular}{|l|c|}
\multicolumn{1}{c|}{ Tipos de trabalhos } & Quantidade \\
\hline Teses & 1 \\
\hline Dissertações & 3 \\
\hline Trabalhos de Conclusão de Curso & 6 \\
\hline Artigos publicados em periódicos, congressos e seminários & 65 \\
\hline Total & 75 \\
\hline
\end{tabular}

FONTE: Autora (2019).

Quanto às áreas de estudo, observou-se que 22,7\% dos trabalhos selecionados versavam sobre o desenvolvimento de aplicativos, 33,3\% sobre a adequabilidade das aplicações móveis, 6,7\% sobre evolução do número de apps disponíveis e 4\% sobre a formação de professores. Os demais trabalhos realizaram, de modo geral, reflexões acerca de estratégias de aprendizagem no ensino da Química a partir do uso de smartphones e apps.

Com relação à temática "Desenvolvimento de aplicativos para o ensino da Química", identificou-se que as 17 pesquisas analisadas apresentaram diferentes metodologias e ferramentas para a construção de softwares voltados às mais diversas áreas da Química, conforme pode ser observado no Quadro 3.

Quadro 3 - Apps desenvolvidos, autores e objetivos gerais.

\begin{tabular}{|c|c|c|}
\hline Aplicativo & Autores & Objetivo geral do aplicativo \\
\hline Libras & $\begin{array}{l}\text { BARROSO; SAMPAIO; } \\
\text { ROCHA (2018) }\end{array}$ & $\begin{array}{l}\text { Facilitar o ensino da Química para indivíduos surdos, por meio de uma } \\
\text { multiplataforma com projeção 3D e voz em tela. }\end{array}$ \\
\hline Modelo Atômico & $\begin{array}{l}\text { BENITE; BENITE; SILVA } \\
\text { FILHO (2011) }\end{array}$ & $\begin{array}{l}\text { Proporcionar a representação e a visualização de modelos atômicos para } \\
\text { alunos do ensino médio. }\end{array}$ \\
\hline Constructor & SILVA (2013) & $\begin{array}{l}\text { Permitir a construção de objetos moleculares virtuais tridimensionais a } \\
\text { partir da fórmula estrutural condensada de espécies químicas. }\end{array}$ \\
\hline $\begin{array}{l}\text { Geometria } \\
\text { Molecular }\end{array}$ & $\begin{array}{l}\text { MENDANHA; COSTA; } \\
\text { BORGES (2015) }\end{array}$ & $\begin{array}{l}\text { Melhorar a compreensão da geometria molecular, propiciando a } \\
\text { visualização e a simulação da Teoria da Repulsão dos Pares Eletrônicos } \\
\text { de Valência e dos tipos de geometria angular, trigonal plana, tetraédrica e } \\
\text { linear. }\end{array}$ \\
\hline $\begin{array}{r}\text { Rea } \\
\text { Aum }\end{array}$ & $\begin{array}{r}\text { PINTO; PILAI } \\
(201 \\
\end{array}$ & $\begin{array}{l}\text { Observar e estudar moléculas químicas de maneira mais interativa, por } \\
\text { meio da realidade aumentada. }\end{array}$ \\
\hline QuiLegAl & OLIVEIRA (2017) & $\begin{array}{l}\text { Integrar e explorar diferentes recursos sonoros, textuais e visuais } \\
\text { envolvendo conteúdos como elementos químicos e ligações químicas; } \\
\text { substâncias químicas e suas representações; e equações e reações } \\
\text { químicas. }\end{array}$ \\
\hline iLaboratory & BERTOLINI ET AL (2013) & $\begin{array}{l}\text { Atuar como um simulador de laboratório par } \\
\text { interativo, de alguns experimentos de Quími }\end{array}$ \\
\hline MoleculAR & $\begin{array}{l}\text { MONTANHA; BAUER; } \\
\text { SILVA (2018) }\end{array}$ & $\begin{array}{l}\text { Permitir a visualização tridimensional de moléculas químicas com o uso } \\
\text { da técnica de realidade aumentada. }\end{array}$ \\
\hline VirtuaLabQ & $\begin{array}{l}\text { RAMOS; PIMENTEL } \\
(2015)\end{array}$ & $\begin{array}{l}\text { Apoiar a prática experimental de transformações químicas por meio de } \\
\text { um ambiente de gamificação. }\end{array}$ \\
\hline StudyLab & $\begin{array}{l}\text { SILVA; SILVA; SILVA } \\
(2015)\end{array}$ & $\begin{array}{l}\text { Auxiliar os usuários a se familiarizarem com os materiais básicos de } \\
\text { laboratório. }\end{array}$ \\
\hline Quimi Crush & PIRES ET AL (2018) & $\begin{array}{l}\text { Possibilitar o estudo das funções orgânicas a partir de um app baseado } \\
\text { no Candy Crush, um aplicativo muito difundido entre os jovens e que } \\
\text { apresenta mais de } 500 \text { milhões de downloads na Play Store. }\end{array}$ \\
\hline
\end{tabular}


Neste grupo, atestou-se que a maioria dos trabalhos focou essencialmente nas etapas percorridas pelo pesquisador para o desenvolvimento do app, no entanto, a dissertação de mestrado "Aplicativo QuiLegAl: uma opção para o ensino de Ciências Naturais" foi além, ao buscar a validação do aplicativo por meio de uma pesquisa de campo na qual participaram 10 professores de quatro escolas estaduais de Mato Grosso (OLIVEIRA, 2017).

A partir da opinião dos docentes que participaram da pesquisa, Oliveira (2017) concluiu que o app é capaz de integrar e explorar diferentes recursos envolvendo os conteúdos relacionados à Química, auxiliando a aprendizagem, favorecendo a participação dos alunos e colaborando, inclusive, para a formação continuada dos docentes, dada a sua capacidade de representar estruturas químicas diversas e emitir feedback ao usuário.

No que se refere ao tópico "Adequabilidade de aplicativos no ensino da Química”, constatou-se que as 25 pesquisas mapeadas procuraram analisar as funcionalidades, potencialidades e limitações para o ensino da Química de aplicações móveis que já se encontravam disponíveis na rede mundial de computadores, como, por exemplo, o Whatsapp, o Kalzium, o Laboratório Virtual Interativo, a Tabela Periódica Interativa e a Periodical Table, entre outros softwares.

Todos os trabalhos foram unânimes em afirmar que essas ferramentas de TIC podem proporcionar importantes benefícios para o processo ensino-aprendizagem da Química. Todavia, algumas pesquisas enfatizaram a necessidade de que as atividades didáticas sejam adequadamente planejadas e orientadas, com o propósito de evitar que o uso dos smartphones em sala de aula prejudique a concentração dos alunos.

Quanto à abordagem "Evolução do número de aplicativos para o ensino da Química", constatou-se, com base nas cinco pesquisas selecionadas, que o número de apps voltados ao ensino da Química tem crescido significativamente nos últimos anos. 0 estudo "Aplicativos para o ensino e aprendizagem de Química" (GRESCZYSCZYN; CAMARGO FILHO; MONTEIRO, 2016), que teve por objetivo investigar as aplicações móveis que podem contribuir para o processo ensino-aprendizagem da Química, identificou mais de 500 aplicativos disponíveis nos repositórios FOSS e Google Play (Figura 2).

Figura 2 - Evolução do número de apps para a educação em Química nos repositórios FOSS e Google Play.

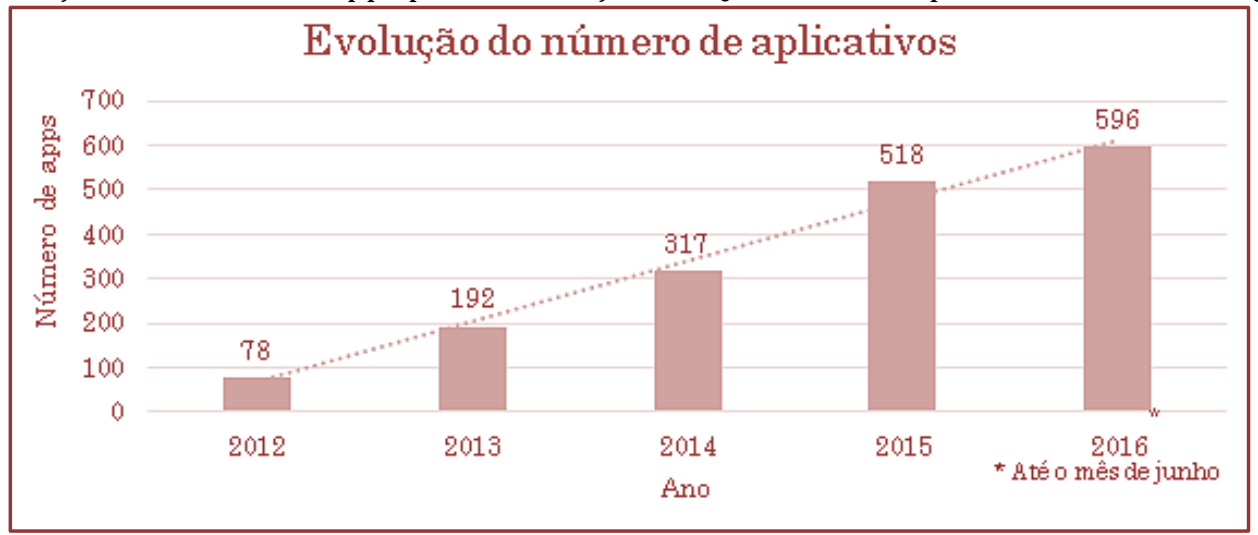

Fonte: Gresczysczyn, Camargo Filho e Monteiro (2016).

Entretanto, mais importante que quantificar o número de aplicativos disponíveis para o processo ensinoaprendizagem da Química, é identificar quais temas têm sido mais contemplados pelos desenvolvedores. Destarte, o artigo "Aplicativos educacionais para smartphones e sua integração com o ensino da Química" (NICHELE; SCHLEMMER, 2014) realizou o mapeamento dos apps disponíveis na App Store em 2014, o que permitiu verificar que o tema mais recorrente é Tabela Periódica, seguido pelos apps que abordam as Ligações Químicas, as Estruturas e os Modelos Moleculares e a Química Orgânica, desde a identificação das funções orgânicas até seus mecanismos de reação.

Na área de pesquisa "Utilização dos dispositivos móveis e aplicativos como estratégia de aprendizagem no ensino da Química”, foram agrupados 25 trabalhos que apresentaram, de modo geral, reflexões e resultados acerca da utilização de dispositivos móveis e aplicativos como recursos metodológicos no ensino da Química. 
Dentro desta temática, Nichele, Schlemmer e Ramos (2015) transformaram os tradicionais roteiros de aula prática de Química em objetos inteligentes. Os autores, visando proporcionar aos estudantes maior aporte no desenvolvimento de atividades laboratoriais, elaboraram vídeos com o detalhamento de algumas técnicas básicas, que eram socializados por meio de QR codes incluídos nos roteiros das aulas práticas disponibilizados previamente.

A inserção desses QR codes numa folha de papel tornava-a um objeto inteligente, pois, a partir da leitura dos códigos de barras por um app instalado nos dispositivos móveis, era possível ter acesso a informações complementares ao roteiro tradicional (NICHELE; SCHLEMMER; RAMOS, 2015).

Cada QR code disponível estava associado a um vídeo com o detalhamento dos procedimentos laboratoriais desenvolvidos, o qual poderia ser acessado a qualquer momento e lugar, permitindo que os estudantes se preparassem antecipadamente para as atividades que seriam realizadas na próxima aula, bem como acessassem o detalhamento da instrução prática durante seu desdobramento, caso necessário (NICHELE; SCHLEMMER; RAMOS, 2015).

Examinando-se pormenorizadamente os trabalhos selecionados notou-se, via de regra, que as estratégias que utilizaram aplicativos gerais - ou seja, não específicos para a Química - foram mais numerosas e caracterizaram-se pela adoção dos dispositivos móveis para o registro de informações geradas em sala de aula, construindo e inserindo imagens, criando e disponibilizando vídeos educativos e utilizando o "armazenamento em nuvem" para o compartilhamento dos registros e arquivos criados por professores e alunos.

As estratégias que utilizaram apps específicos para o ensino da Química desnudaram, em especial, o potencial dos smartphones e tablets em proporcionar aos estudantes melhor visualização e entendimento de alguns temas considerados de difícil compreensão, tais como estruturas moleculares, isomeria, reações orgânicas, estequiometria e funções inorgânicas.

Ambas as abordagens se caracterizaram por incentivar a adoção do mobile learning por meio do BYOD (do inglês bring your own device - traga seu próprio dispositivo), proporcionando a continuidade das atividades desenvolvidas em sala de aula para além dos muros escolares.

Por derradeiro, quanto aos objetivos das 75 pesquisas mapeadas, verificou-se a existência de oito vertentes principais:

a) investigar o uso das tecnologias móveis como estratégia de aprendizagem no ensino da Química;

b) investigar a adequabilidade dos apps no processo ensino-aprendizagem da Química;

c) analisar as potencialidades das aplicações móveis na obtenção de conhecimento químicos;

d) investigar a evolução do número de aplicativos para o ensino da Química e temas mais recorrentes;

e) investigar as mudanças provocadas nas aulas de Química pela inclusão dos dispositivos móveis nas práticas pedagógicas;

f) relatar as experiências e as etapas seguidas para o desenvolvimento de apps voltados à educação em Química;

g) relatar experiências no uso de dispositivos móveis e aplicativos na sala de aula como recurso didático no ensino da Química;

h) apresentar e descrever aplicações móveis direcionadas ao aprendizado da Química.

A título de parecer final, pode-se afirmar que os trabalhos publicados, embora apresentem finalidades diversas, destacam as várias possibilidades do uso de dispositivos móveis e aplicativos em sala de aula, desmistificando a ideia de "salvadores" ou "inimigos" do processo ensino-aprendizagem. Em todos os casos, percebe-se que a tecnologia móvel pode - e deve - ser utilizada de maneira intencional e planejada com vistas à melhoria do ensino e a facilitação do aprendizado em Química.

Importante observar ainda que todas as estratégias de ensino e de aprendizagem analisadas podem ser reproduzidas ou adaptadas pelos professores, tanto para a educação básica quanto superior, e não apenas no âmbito da Química, mas também em outras áreas do conhecimento humano, bem como no desenvolvimento de atividades interdisciplinares. 


\section{CONCLUSÃO}

Neste artigo, buscou-se examinar como está ocorrendo o desenvolvimento das pesquisas sobre o uso dos dispositivos móveis e aplicativos no ensino da Química, abordando tanto aspectos quantitativos como qualitativos.

Do ponto de vista científico, o trabalho de revisão bibliográfica mostra-se extremamente importante, pois possibilita maior aprofundamento do assunto abordado, permitindo ao pesquisador identificar o que pode ser aprendido a partir de estudos semelhantes realizados no passado: seus objetivos, procedimentos, problemas e soluções.

A análise das pesquisas selecionadas possibilitou responder à pergunta norteadora desse estudo. Constatou-se que os dispositivos móveis e aplicativos têm sido utilizados amplamente como recursos auxiliares no processo ensino-aprendizagem da Química. No entanto, foi possível observar que o uso dessas ferramentas ainda representa uma temática que necessita ser consolidada como campo de pesquisa educacional.

A maioria das pesquisas sobre o uso de dispositivos móveis no ensino da Química foi realizada nos últimos três anos. A análise da finalidade das pesquisas selecionadas para este estudo permitiu identificar que os estudos focam na utilização dos dispositivos móveis como ferramenta de ensino-aprendizagem, apresentando experiências a partir de estudos de caso ou situações de ensino-aprendizagem escolar.

Quanto à resposta à terceira questão norteadora (Quais aspectos ainda não foram explorados?), verificouse que as pesquisas que apresentam relatos de experiências com formação de docentes para utilização desses dispositivos em sala de aula ainda são incipientes. Tal constatação revela a necessidade de ampliação e aprofundamento de estudos que tratam da formação e atualização de professores para o uso de dispositivos e aplicações móveis em sala de aula.

Outro ponto pouco explorado diz respeito a pesquisas que apresentem resultados da aprendizagem dos alunos a partir da utilização desses dispositivos como recursos didáticos em sala de aula. Igualmente, verificou-se que, apesar do elevado número de aplicativos disponíveis na internet, não foram identificados na literatura estudos sobre o desenvolvimento de apps a partir da percepção de professores e alunos. Em outras palavras, não há pesquisas que tenham apresentado e analisado o processo de construção de aplicativos a partir da opinião, ideias e necessidades daqueles que estão envolvidos diretamente no processo ensino-aprendizagem.

\section{REFERÊNCIAS}

[1] Barroso, M. C. S.; Sampaio, C. G.; Rocha, A. M. Ensino de Química por meio da libras: a utilização de software educacional. In: 58o Congresso Brasileiro de Química, 2018. Disponível em: <http://www.abq.org.br/cbq/2018/trabalhos/9/1857-26781.html>. Acesso em: 17 abr. 2019.

[2] Benite, A. M. C.; Benite, C. R. M.; Silva Filho, S. M. Cibercultura em ensino de Química: elaboração de um objeto virtual de aprendizagem para o ensino de modelos atômicos. Química Nova na Escola, v. 33, n. 2, p. 71-76, mai. 2011. Disponível em: <http://qnesc.sbq.org.br/online/ qnesc332/01-EQM3010.pdf>. Acesso em: 23 abr. 2019.

[3] Bernardo, W. M.; Nobre, M. R. C.; Jatene, F. B. A prática clínica baseada em evidências: parte II - buscando as evidências em fontes de informação. Rev. Assoc. Med. Bras., São Paulo, v. 50, n. 1, 2004. Disponível em: <http://dx.doi.org/10.1590/S0104-42302004000100045>. Acesso em: 08 maio 2019.

[4] Bertolini, C. T.; Braga, J. C.; Pimentel, E.; Ramos, S. Laboratório virtual interativo para reprodução de experimentos de Química através de dispositivos móveis. In: XXIV Simpósio Brasileiro de Informática na Educação (SBIE 2013), p. 285-295. Disponível em: <http://www.br-ie.org/pub/index.php/ sbie/article/view/2507>. Acesso em: 23 maio 2019.

[5] Giordan, M. Computadores e linguagens nas aulas de ciências. Ijuí: Ed. Unijuí, 2008.

[6] Grasel, P. M-learning e u-learning: novas perspectivas das aprendizagens móvel e ubíqua. Resenha. Revista Espaço Pedagógico. v. 20, n. 2, Passo Fundo, p. 406-411, jul./dez. 2013. Disponível em: <www.upf.br/seer/index.php/rep>. Acesso em: 05 abr. 2016.

[7] Gresczysczyn, M.C.C.; Camargo Filho, P.S.; Monteiro, E.L. Aplicativos educacionais para smartphone e sua integração com o ensino de Química. Rev. Ens. Educ. Cienc. Human., Londrina, v.17, n.esp. Selitec 15/16, p.398-403, 2016. Disponível em: <http://revista.pgsskroton. com.br/index.php/ensino/article/view/4536/3484>. Acesso em: 17 abr. 2019. 
[8] Jacon, L. S. C. Dispositivos móveis no ensino de Química: o professor formador, o profissional de Informática e os diálogos possíveis. Tese de doutorado, 2014. Disponível em: <http://www.ufmt.br/ ppgecem/arquivos/4a3590f18482ac5cd564cc640c080f99.pdf> Acesso em: 01 de abr. 2019.

[9] Locatelli, A.; Zoch, A. N.; Trentin, M. A. TICs no ensino de Química: um recorte do "estado da arte". Revista Tecnologias na Educação, Vol. 12, no. 7, 2015.

[10] Lopes, I. L. Estratégia de busca na recuperação da informação: revisão da literatura. Ciência da Informação, Brasília, v. 31, n. 2, p. 60-71, maio-ago. 2002. Disponível em: <http://www.scielo.br/ pdf/ci/v31n2/12909.pdf>. Acesso em: 12 abr. 2019.

[11] Martinho, T.; Pombo, L.; Potencialidades das TIC no ensino das Ciências Naturais - um estudo de caso. Revista Electrónica de Enseñanza de las Ciencias, v. 8, n. 2, p. 527-538, 2009. Disponível em: <http://reec.uvigo.es/volumenes/ volumen8/ART8_Vol8_N2.pdf>. Acesso em: 21 abr. 2019.

[12] Meirelles, F. S. Tecnologia de Informação. 29a Pesquisa Anual do Uso de TI - 2018. Disponível em: <https://eaesp.fgv.br/sites/eaesp.fgv.br/files/pesti2018gvciappt.pdf>. Acesso em: 18 abr. 2019.

[13] Meir, J. As 6 características fundamentais da Geração Z. Disponível em: <https://www. consumidormoderno.com.br/2017/09/22/caracteristicas-fundamentais-geracao-z/>. Acesso em: 19 de maio 2019.

[14] Mendanha, A. A.; Costa, L. L.; Borges, R. C. Desenvolvimento de um aplicativo móvel voltado ao ensino de Geometria Molecular. Nuevas Ideas en Informática Educativa TISE 2015. Disponível em: <http://www.tise.cl/volumen11/TISE2015/735-738.pdf>. Acesso em: 20 maio 2019.

[15] Montanha, A. L.; Bauer, R. D.; Silva, D. F. MoleculAR: um aplicativo em Realidade Aumentada para o aprendizado de Química. Encontro Anual de Tecnologia da Informação, 2018. Disponível em: <http://eati.info/eati/anais-2018/Curtos/C15.pdf>. Acesso em: 28 maio 2019.

[16] Nichele, A. G.; Schlemmer, E. Aplicativos para o ensino e aprendizagem de Química. Revista Novas Tecnologias na Educação, v. 12, n. 2, 2014.

[17] Nichele, A. G.; Schlemmer, E.; Ramos, A. F. QR codes na educação em Química. Revista Novas Tecnologias na Educação, v. 13, n. 2, 2015.

[18] Oliveira, F. C. Aplicativo QuiLegAl: uma opção para o ensino de Ciências Naturais. Dissertação de mestrado, 2017. Disponível em: <http://portal.unemat.br/media/files/Fabio_Caires_de_Oliveira.pdf>. Acesso em: 07 maio 2019.

[19] Pereira, A. L.; Bachion, M. M. Atualidades em revisão sistemática de literatura, critérios de força e grau de recomendação de evidência. Revista Gaúcha de Enfermagem, v. 27, n. 4, p. 491, 2006. Disponível em: <www.seer.ufrgs.br/RevistaGauchadeEnfermagem/article/viewFile/4633/2548>. Acesso em: 18 abr. 2019.

[20] Pinto, L. T. G.; Pilan, J. R.; Almeida, O. C. P. Desenvolvimento de um aplicativo para ensino de Química usando realidade aumentada. In: VII Jornada Científica e Tecnológica - Jornacitec da Faculdade de Tecnologia de Botucatu FATEC, 2018, Botucatu. Anais da VII Jornada Científica e Tecnológica - Jornacitec da Faculdade de Tecnologia de Botucatu - FATEC, 2018. Disponível em: <http://fatecbt.edu.br/ocs/index.php/VIIJTC/VIIJTC/paper/viewFile/ 1673/2145>. Acesso em: 30 abr. 2019.

[21] Pires, D. A. T.; Nascimento, L. A.; Medeiros, T. M.; Loja. L. F. B. Quimi Crush: atividade lúdica para o ensino de Química Orgânica. Revista Prática Docente, 2018. Disponível em: <http://dx.doi.org/10.23926/RPD.25262149.2018.v3.n2.p625-642.id264>. Acesso em: 13 maio 2019.

[22] Ramos, S.; Pimentel, E. P. VirtuaLabQ ambiente gamificado para a prática experimental de transformações químicas. In: Simpósio Brasileiro de Informática na Educação - SBIE, 2015. Disponível em: <http://www.brie.org/pub/index.php/sbie/article/view/5320>. Acesso em: 15 maio 2019.

[23] Reinaldo, F.; Magalhaes, D. R.; Reis, L. P.; Gaffuri, S.; Freddo, A.; Hallal, R. Impasse aos desafios do uso de smartphones em sala de aula: investigação por grupos focais. RISTI (Revista Ibérica de Sistemas e Tecnologias de Informação), 2016. Disponível em: <http://www.scielo.mec.pt/pdf/rist/n19/n19a07.pdf>. Acesso em: 25 abr. 2019.

[24] Saccol, A.; Schlemmer, E.; Barbosa, J. M-learning e u-learning: novas perspectivas das aprendizagens móvel e ubíqua. São Paulo: Prentice Hall, 2011.

[25] Silva, C. N. N.; Porto, M. D. Metodologia científica descomplicada: prática científica para iniciantes. Brasília: Editora IFB, 2016.

[26] Silva, P. F.; Silva, T. P.; Silva; G. N. StudyLab: construção e avaliação de um aplicativo para auxiliar o ensino de Química por professores da Educação Básica. Revista Tecnologias na Educação - ano 7 - número 13 - dezembro, 2015. Disponível em: <http://tecnologiasnaeducacao.pro.br/>. Acesso em: 13 abr. 2019.

[27] Silva, J. G. Desenvolvimento de um ambiente virtual para estudo sobre representação estrutural em Química. Tese de doutorado, 2013. Disponível em: <http://www.teses.usp.br/ teses/disponiveis/81/81132/tde-23042013123423/pt-br.php>. Acesso em 10 abr. 2019. 
[28] Silva, L. R. C. O uso de aplicativos para smartphones e tablets no ensino de Física: análise da aplicabilidade em uma universidade pública no Estado do Rio Grande do Sul. In: Congresso Nacional de Educação, 13., 2017, Paraná. Anais... Paraná: PUCPR, 2017. Disponível em:<http://bit.ly/2HVckgh>. Acesso em: 28 abr. 2019.

[29] Siqueira, R. N. Métodos de ensino adequados para o ensino da geração Z, uma visão dos discentes. Artigo do curso de especialização em administração da Universidade Federal de Mato Grosso, 2012. Disponível em: <http://livrozilla.com/doc/ 1192527/uma-vis\%C3\%A3o-dos-discentes--um-estudo>. Acesso em: 21 maio 2019.

[30] Souza, M. T.; Silva, M. D.; Carvalho, R. Revisão integrativa: o que é e como fazer. Einstein, Morumbi, v. 8, n. 1, p. 102-106, 2010. Disponível em: <http://pt.scribd.com/doc/56528038/ A2-Revisao-integrativa-o-que-e-e-comofazer>. Acesso em: 15 maio 2019.

[31] Voss, G. B.; Nunes, F. B.; Herpich F.; Medina, R. D. Ambientes virtuais de aprendizagem e ambientes imersivos: um estudo de caso utilizando tecnologias de computação móvel. In: II Congresso Brasileiro de Informática na Educação (CBIE 2013). Disponível em: <https://www.researchgate.net/profile/

Gleizer_Voss/publication/268078497_Ambientes_Virtuais_de_Aprendizagem_e_Ambientes_Imersivos_um_estudo_de_ caso_utilizando_tecnologias_de_computacao_movel/links/546161270cf2c1a63bff853f.pdf >. Acesso em: 10 abr. 2019. 


\section{Capítulo 12}

Uma avaliação do modelo sala de aula invertida no ensino superior

\section{Adriana Doroteu Dantas}

Luiz Sérgio Oliveira Barbosa

Isomar Lima da Silva

Thaís Helena Chaves de Castro

Nara Vieira da Silva

Antônio Ribeiro da Costa Neto

Resumo. Este artigo apresenta uma avaliação que teve como objetivo incentivar a aprendizagem ativa e analisar o comportamento de uma turma de pós-graduação em Informática na Educação do Instituto Federal do Amazonas quanto à utilização do modelo sala de aula invertida. Para a realização da pesquisa foi feita uma avaliação durante a oferta de uma das disciplinas do curso. 0 resultado deste trabalho foi relevante para toda a equipe, no sentido de contribuir na preparação de professores, na mudança da metodologia de tutoria, na postura dos alunos em relação ao ensino e aprendizagem em Educação à Distância. 


\section{INTRODUÇÃO}

A modalidade de Educação à Distância vem se tornando cada vez mais frequente nas instituições de ensino, assumindo um importante papel no cenário educacional do país, em particular na formação em nível superior de setores da população que dificilmente alcançariam essa categoria de escolaridade, por fatores sociais e econômicos diversos. Essa modalidade viabiliza a formação em horários flexíveis distintos dos horários em ambientes escolares presenciais, possui um alcance geográfico muito abrangente, assim como a possibilidade de redução de custos na formação profissional do cidadão [Ramos et al. 2014a].

No entanto, Valente (2013) afirma que o ensino superior nessa modalidade enfrenta atualmente dois grandes desafios. 0 primeiro deles é em relação às salas de aula, cada vez mais vazias ou quando o aluno está presente, ele está fazendo outra coisa diferente do que acompanhar a aula. No trabalho de Ribeiro et al. (2014) é relatado bem a deficiência apresentada acima, segundo um dos desafios para superar os alarmantes índices de evasão na EaD passa pela identificação e compreensão das diferentes ações de efetividade que os gestores são chamados a intervir, pois estes através do seu poder de decisão: definem, organizam e implementam as ações necessárias para o sucesso do processo de ensino-aprendizagem. Sendo a evasão um aspecto que envolve o ensino à distância cada vez mais presente nas Instituições de Ensino Superior (IES) Ribeiro et. al (2014), caput Daudt e Behar, (2013), esta pesquisa busca identificar parâmetros que possam contribuir para minimizar os índices de desistência através de análises dos relatórios de conclusão e da correlação destes com a avaliação da percepção dos alunos ao final de duas edições do curso.

O segundo desafio apontado por Valente (2013) é a incapacidade de atender a grande demanda de alunos que querem ingressar no ensino superior. Assim, o modelo de universidade que faz pesquisa, gera conhecimento e distribui este conhecimento para poucos não se sustenta mais. No intuito de minimizar essa problemática, Valente (2013) e Herreid (2013) propõem a utilização de inovações metodológicas e ambos afirmam ainda que as soluções a serem adotadas exigem mudanças no processo de ensino e aprendizagem, que são muito mais profundas, especificamente com relação à sala de aula, ela terá de ser repensada na sua estrutura, bem como na abordagem pedagógicaque tem sido utilizada.

Diante do exposto, o objetivo deste artigo é apresentar uma avaliação utilizando o modelo de sala de aula invertida, essa nova metodologia é uma tendência inovadora na modalidade de ensino à distância no país, com o intuito de incentivar a aprendizagem ativa e que demonstrou resultados relevantes não só para os alunos, mas para toda equipe do curso de pós-graduação.

\section{REFERENCIAL TEÓRICO}

A Sala de Aula Invertida (SAI), em língua inglesa Flipped Classroom, é um modelo de rotação na qual os alunos estudam os conteúdos de modo on-line, em casa, na escola ou em algum outro espaço escolhido pelo aluno, e o tempo em sala de aula é reservado para atividades de aprendizagem com o acompanhamento do professor, relata [Mendonça, 2015].

A sala de aula invertida ou modelo instrutivo, foi desenvolvido por Jonathan Bergmann e Sams Aaron, em 2007 no intuito de fornecer instruções para alunos do ensino secundário que estavam faltando às aulas presencias de química, portanto, ausentes das instruções do professor.

Figura 1. Método da Sala de Aula Invertida por Teaching \&Assessment, (2015)

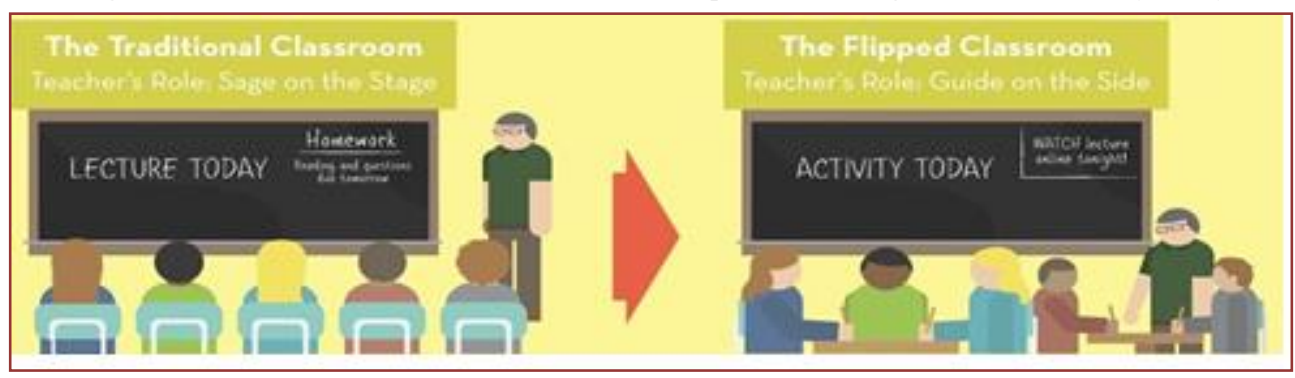


De acordo com Mendonça (2015) no estudo on-line os alunos se apropriam do conteúdo de forma autônoma, utilizando-se de vídeo-aulas, textos, listas de exercícios e outros recursos indicados pelo professor por meio de um roteiro de aprendizagem previamente planejado, podendo ainda ampliar esse repertório a partir de suas pesquisas pessoais. Ao chegar à sala de aula os alunos já tinham todo o conhecimento referente ao conteúdo on-line, passando a se dedicar em tirar dúvidas sobre o material exposto, esclarecer resoluções de atividades, trabalhos em grupo e outras atividades voltadas ao conteúdo.

A sala de aula invertida está sendo vivenciada por diversas instituições em turmas que vão do jardim da infância até a universidade. No caso das escolas públicas, mais carentes de recursos, o que entra em cena é a iniciativa do professor, assim como sua formação continuada que o ajuda a ser mais conectado com essa prática pedagógica afirma [Lacoste 2014].

\section{TRABALHOS RELACIONADOS}

A partir de uma pesquisa teórica realizada, foram detectados poucos trabalhos referenciando o método da sala de aula invertida no Brasil, no entanto, em outros países foram encontrados vários exemplos de trabalhos referênciando o método há algum tempo.

A experiência descrita por Mendonça (2015), por exemplo, aconteceu na Escola Municipal Professora Thereza Favali Pocay em Salto Grande, Estado de São Paulo, nas disciplinas de História, Ciências e Geografia, com 18 alunos do 5o ano do Ensino Fundamental, divididos em 9 duplas. Os momentos em sala de aula aconteceram em 2 aulas de 55 minutos. 0 objetivo da aplicação do método era que os alunos aprendessem sobre o ambiente em que viviam.

Na prática vivida por Tuker (2012) relata sobre a experiência vivida pelos autores do método, ambos perceberam que deveriam repensar radicalmente sobre a forma de como eles usariam o tempo de aula, a idéia central era de inverter a instrução comum da abordagem: com vídeos criados pelos professores e aulas interativas, instrução que costumavam ocorrer na classe seria acessada em casa, quando e quantas vezes quisessem. Dessa forma a sala de aula torna-se o lugar para se trabalhar através de problemas, avançar conceitos, e se envolver aprendendo em colaboração.

A experiência com a adoção do modelo SAI é a da professora Haberman que em seu blog My Flipped Classrom Experience, documenta seu projeto de pesquisa-ação NASA Endeavor Program sobre a Sala de Aula Invertida. A experiência aconteceu na Scottsbluff High School de Nebraska, com 129 alunos do $10^{\circ}$ ao $12^{\circ}$ ano, onde no Brasil é comparado ao $1^{\circ}, 2^{\circ}$ e $3^{\circ}$ ano do Ensino Médio, na disciplina de Biologia. 0 objetivo da aplicação era que os alunos aprendessem mais sobre a disciplina de forma consistente utilizando todo o conteúdo da sala de aula, afirma [Mendonça 2015].

0 trabalho de Bishop (2013) fornece uma pesquisa abrangente de investigação prévia e contínua da sala de aula invertida. Esses estudos são caracterizados em várias dimensões entre outros, estes incluem os tipos de estudos em sala de aula e fora dela, a média de atividades utilizadas para avaliar o estudo, e metodologias características de cada estudo. Os resultados desta pesquisa mostram que a maioria dos estudos realizados até a data explora as percepções dos alunos e usam desenhos de estudo em grupo único. Os relatórios de percepções de estudantes da sala de aula invertida são um pouco mistos em relação à satisfação, mas geralmente com resultados positivos.

E Zhang et. al (2013) descreve uma experiência positiva da sala de aula invertida em um curso de pósgraduação, o artigo fala ainda da pespectiva da aprendizagem a partir do desenvolvimento da metodologia de gameficação dentro da sala de aula invertida. As atividades expostas de forma diferenciada com textos objetivos para os alunos facilitam o aprendizado.

No trabalho de Zhong et. al (2013) ressalta a importância do desing instrucional no desenvolvimento da sala de aula invertida, o mesmo afirma ainda que é a parte mais importante para a intenção da aplicação do método. 0 modelo de instrução simplificada deve ser utilizado de forma organizada dentro da sala de aula invertida. 


\section{AVALIAÇÃo}

\subsection{PROBLEMA}

Através de relatórios feitos pelos tutores do curso de pós-graduação em informática na educação foi detectado que o acesso às salas e as atividades são tardios, afetando assim o cronograma inicial da disciplina e consequentemente o andamento do curso.

Em uma análise rápida foi percebido que os alunos esperavam os professores para explicação do conteúdo e realização das atividades nas aulas presenciais, caracterizando-se como uma turma de alunos passivos, sempre a espera do professor para despertar o processo de aprendizagem.

\section{2 .OBJETIVO}

Incentivar aprendizagem ativa a partir da aplicação do método da sala de aula invertida e analisar o comportamento e desempenho dos alunos em relação à utilização do método, essa avaliação foi realizada a partir da análise de dados gerados pela elaboração de atividades realizadas pelos alunos no intuito de identificar o potencial de aprendizagem da turma em relação às outras disciplinas.

\section{3 .PROCEDIMENTOS METODOLÓGICOS}

Esta avaliação contou com dois tipos de pesquisas, a teórica e a descritiva, o principal objeto de análise foi o número de acessos dos alunos a partir da realização de atividades no ambiente.

\subsection{POLO DE PESQUISA}

0 ambiente Moodle utilizado no Instituto Federal do Amazonas possui outras instâncias, o curso de pósgraduação em Informática na Educação do Instituto é ofertado para 4 polos, incluindo capital e interior, a pesquisa descrita foi realizada em 1 dos 4 polos.

\subsection{PREPARAÇÃO DO AMBIENTE}

Para a preparação do ambiente foi necessário um estudo adequado de leituras de artigos e análise de alguns modelos de salas voltadas à aplicação desse método. Segundo

Lacoste (2014) as práticas de sala de aula invertida consistem em oferecer aos alunos textos, vídeos ou conteúdo adicional para estudo fora da sala de aula.

Foram selecionadas atividades individuais e em grupo acompanhadas de vídeos, textos e cronogramas com aulas dinâmicas e práticas para estimular a realização das atividades no ambiente. Além disso, a sala passou por uma avaliação que contou com a participação de uma equipe composta por duas pedagogas, um design instrucional, dois professores da área de informática e pela coordenação do curso.

\subsection{CENÁRIO DO ESTUDO DE CASO}

A sala de aula proposta contava com quatro tópicos, descritos da seguinte forma:

1 o Tópico - Mostra a apresentação do Professor, apresentação da disciplina, plano de ensino da disciplina e cronograma com instruções de como realizar as atividades e datas de entrega de cada tarefa da disciplina.

2o Tópico - Apresentam textos com conteúdos resumidos, vídeos que abordam e descrevem o texto para facilitar o entendimento dos alunos sobre o conteúdo. 0 tópico conta ainda com duas atividades que são o fórum e o questionário.

3 o Tópico - Apresentam 3 atividades, uma delas é o fórum, a segunda atividade é o envio de arquivo único, e a terceira atividade proposta foi em grupo, para realização dessa atividade os alunos contaram com a ajuda de vídeos que descreviam algumas dicas de como resolver o problema proposto.

4o Tópico - Apresentam 2 atividades, o envio de arquivo único e o fórum, a primeira atividade foi uma apresentação sobre o tema proposto pelo professor para cada equipe, essas apresentações foram feitas 
para o professor como nota final da disciplina.

\subsection{TIPOS DE ATIVIDADES DO CENÁRIO}

\subsubsection{ATIVIDADES INDIVIDUAIS}

Os alunos acessaram o ambiente e realizaram as atividades que estavam expostas para eles, sendo:

1.Responder a um questionário onde as respostas estavam em um texto disponibilizado na sala onde eles deveriam fazer o download do arquivo para responder as perguntas.

2.Fazer o upload do arquivo.

3.Respostas no fórum a respeito dos textos lidos.

\subsubsection{ATIVIDADES EM GRUPO}

Os alunos foram divididos em grupos obedecendo ao critério da ordem alfabética, sendo:

1.Resolver em grupo um problema proposto sobre acessibilidade na escola. Para cada grupo foi distribuído uma dica diferente no intuito de ajudá-los a resolver o problema. Para resolver o problema, os membros do grupo deveriam interagir usando o chat ou mensagens como meio de comunicação.

2.0 conteúdo do arquivo único deve conter a apresentação dos alunos a respeito das boas práticas de cada tema de proposto.

\subsection{PERFIS DOS PARTICIPANTES}

Os participantes foram alunos do Curso de Pós-graduação em Informática na Educação e ocorreu durante a disciplina Acessibilidade e Informática na Escola Inclusiva. A turma é formada por 30 alunos, com idades entre 28 e 59 anos, muitos alunos são professores do ensino fundamental e médio da rede pública de ensino do estado do Amazonas.

Todos os participantes assinaram um Termo de Consentimento Livre e Esclarecido que descrevia todo o processo de pesquisa, o objetivo e a importância da veracidade da resposta de cada participante para a pesquisa.

\subsection{EXECUÇÃO DA AVALIAÇÃO}

A avaliação foi realizada em março de 2015, e teve um período de 30 dias, o mesmo tempo que leva a oferta de uma disciplina regular no curso, o conteúdo foi disponibilizado para os participantes na sala virtual 20 (vinte) dias antes da aula presencial, os alunos tiveram vários dias para visualizar todo o conteúdo e tentar responder as atividades do ambiente sozinhos ou em grupo, sem nenhuma ajuda primária do professor, somente utilizando o material disponível em sala de aula.

O professor antes de ministrar as aulas presenciais, verificou as questões mais problemáticas e dúvidas mais pertinentes dos alunos, essas dúvidas são trabalhadas em sala de aula no intuito de dar um feedback mais objetivo aos alunos. Durante a aula, as discussões são intercaladas e destinadas a expor as dificuldades que os alunos encontram em realizar as atividades. Algumas dúvidas são respondidas via mensagem, no fórum ou chat, de modo que a classe e o professor possam acompanhar o nível de compreensão sobre os conceitos em discussão.

Para a atividade colaborativa os alunos foram divididos em 4 grupos de 6 pessoas, e um grupo de 4 pessoas, dando um total de 5 grupos, onde cada aluno ficaria responsável por apresentar um trabalho sobre um tipo de deficiência, os temas ficaram divididos da seguinte forma:

1-Pessoas com deficiência Física/Mobilidade

2-Pessoas com deficiência Visual

3-Pessoas com deficiência Auditiva

4-Pessoas com deficiências Multiplas/Comunicação

5-Acessibilidade na Web/Recursos de Tecnologias Assistivas para percepção e operação. 
Para essa atividade cada grupo ficou responsável por pesquisar sobre um mesmo tema, dessa forma no final cada grupo apresentou sua contribuição de pesquisa relacionada ao tema proposto, com contribuições relevantes para a resolução de problemas do cotidiano desses usuários que merecem toda a nossa atenção como qualquer outro aluno.

Para realização dessa atividade foi disponilizado vídeos que contavam depoimentos vividos por pessoas com diversas deficiências, no intuito de sensibilizar os alunos e despertar o senso crítico para contribuir de alguma forma para o bem-estar desses alunos em sala de aula.

\subsection{COLETA DOS DADOS}

A coleta de dados foi feita no próprio ambiente virtual a partir dos logs dos alunos, foi realizado um questionário dentro da sala de aula da disciplina onde os alunos responderam quanto a algumas questões pertinentes ao estudo de caso. Todos os alunos responderam o questionário, mas nem todos os alunos fizeram todas as atividades.

De acordo com Ramos et al. (2014b) o Moodle dispõe da ferramenta "Pesquisa" que pode ser facilmente configurada para realizar pesquisas e enquetes com diferentes tipos de questões. A ferramenta permite exportar os dados coletados em formato de planilha, facilitando análises mais aprofundadas através da utilização de ferramentas estatísticas e de mineração de dados.

\section{RESULTADOS DA AVALIAÇÃo}

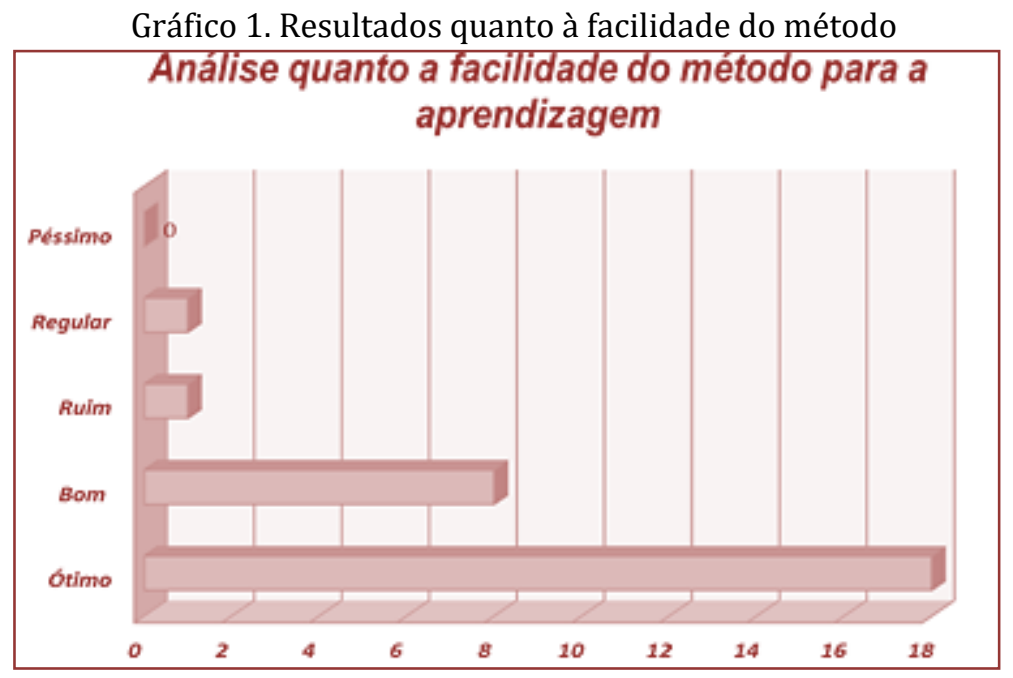

Gráfico 2. Resultados quanto a Entrega das Atividades

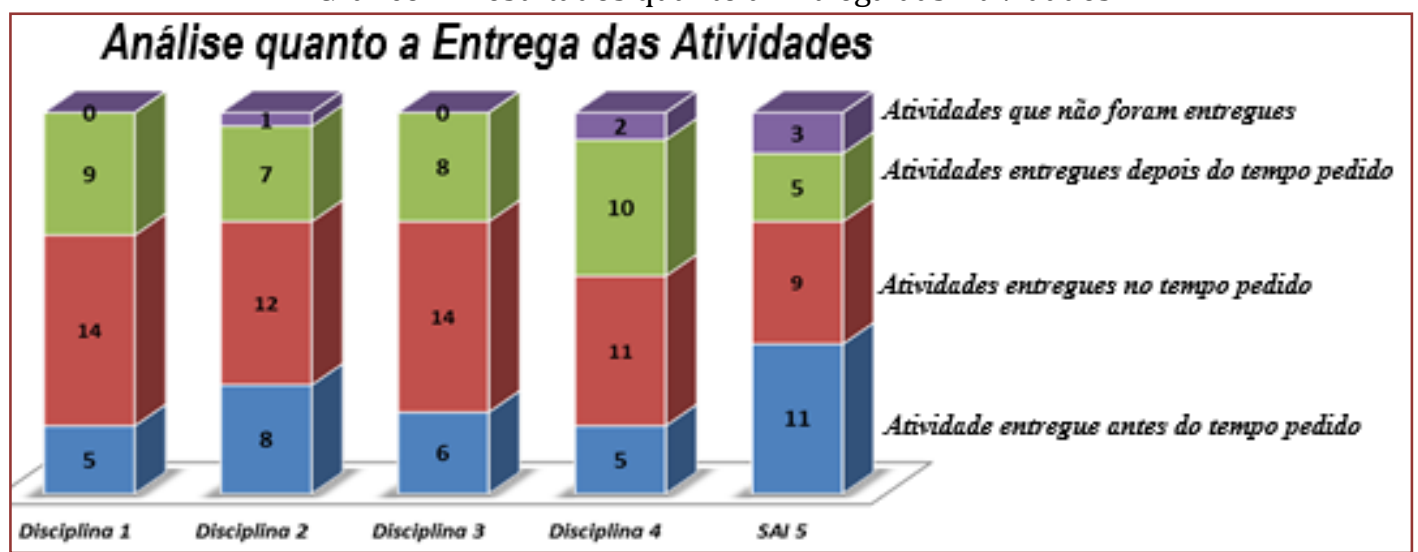


Gráfico 3. Resultados quanto à quantidade de alunos aprovados

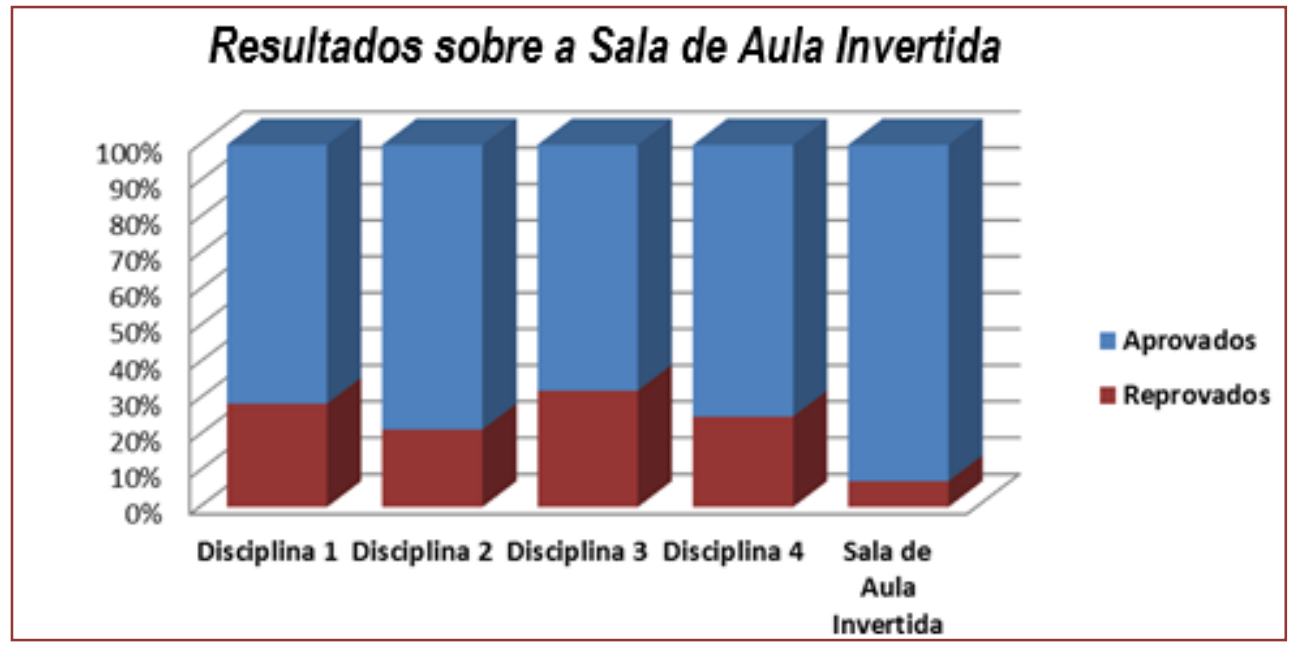

No geral os resultados sobre a avaliação da sala de aula invertida mostraram-se positivos, em uma comparação feita entre a disciplina que utilizou a sala de aula invertida e as outras disciplinas que utilizaram o método convencional, foram notáveis as diferenças dos resultados. Os gráficos acima mostram os resultados em três aspectos diferentes e todos eles mostram resultados positivos na utilização do método da sala de aula invertida.

0 gráfico 1 mostra que 18 de 28 alunos escolheram ótimo e 8 optaram por bom, quanto à facilidade de uso do método. No gráfico 2 mostra a entrega de atividades dos alunos em relação a todas as disciplinas e 11 de 28 alunos entregaram as atividades antes do tempo pedido, 9 alunos entregaram as atividades no tempo certo. No gráfico 3 mostra a quantidade de alunos aprovados e reprovados nas disciplinas em relação à utilização do método convencional e do método da sala de aula invertida.

\section{CONCLUSÕES DO ESTUDO DE CASO}

\subsection{PONTOS DE VISTA POSITIVOS DO MÉTODO}

A partir da aplicação do método pôde ser percebida uma participação mais ativa dos alunos da turma, assim como o aumento no índice na realização das atividades, o que contribuiu para a aprovação de grande parte dos alunos na disciplina. A maioria dos alunos relatou que o modelo da sala de aula chamou a atenção deles e facilitou a realização das atividades.

A metodologia de tutoria também sofreu mudanças durante a oferta desta disciplina e se tornou naturalmente menos ativo devido à redução na quantidade de postagens de dúvidas dos alunos para o professor, dessa forma os tutores tiveram mais tempo para acompanhar melhor os alunos nas atividades em grupo. Para a coordenação do curso a qualidade da sala foi um dos pontos mais importantes e decisivos para que o método atingisse resultados relevantes para toda a equipe.

Valente (2013) afirma que na sala de aula invertida, professores qualificados são mais importantes do que nunca. São eles que devem definir o conteúdo, as instruções e traçar as estratégias de interação face a face. Durante a aula, devem observar e dar feedback, além de avaliar continuamente o trabalho do aluno.

Foi identificada a necessidade de realizar treinamentos mais específicos com os professores do curso para as próximas disciplinas em relação à preparação de material mais elaborado para a sala de aula.

A preparação de um bom material e a forma como são organizados na sala naturalmente induz o aluno ao aprendizado imediato de forma precisa, sem a necessidade de leituras longas e cansativas.

\subsection{PONTOS DE VISTA NEGATIVOS DO MÉTODO}

A preparação da sala de aula deve ser minuciosa, o que leva um tempo e habilidade do professor na 
utilização das TCDS, a resistência de alguns alunos em realizar as atividades sem a instrução do professor, e o tempo de feedback do professor para os alunos que deve ser frequente.

De acordo com Valente (2013) como em qualquer modelo ou método de ensino, a sala de aula invertida pode ser adotada de forma errada. Logo, é importante notar quea iniciativa pode não funcionar para todos os professores e alunos, assim como para diferentes níveis e disciplinas. Nem todos os educadores terão sucesso e alguns alunos podem preferir as abordagens tradicionais, mas é uma boa alternativa para um mundo globalizado em que o uso da tecnologia e da comunicação aplicados à educação é cada vez maior.

\section{TRABALHOS FUTUROS}

Como ilustrado ao longo deste trabalho, a investigação mais qualitativa e quantitativa precisa ser feita para identificar como o potencial do modelo pode ser maximizado. Mas a pesquisa existente demonstra claramente que o modelo de aprendizagem da sala de aula invertida pode ser uma maneira de criar um ambiente centrado no aluno.

Gorman (2012) observaram que qualquer educador que faz suas atividades centradas no aluno poderia proporcionar atividades na sala de aula que são baseados em ação, autênticidade, conectividade, colaboração, inovação de alto nível, envolvimento, experiência com base, aprendizagem aprofundada e auto realização.

Empregar estudos controlados com o objetivo de avaliar o desempenho dos alunos em um semestre também pode ser uma possibilidade de mostrar o potencial do método. Além disso, recomendamos que os pesquisadores utilizem e estimulem a sala de aula investida como forma de avaliar seu próprio material teórico e as atividades existentes na sala no intuito de melhorar seu design e forma de metodologia.

Espera-se que conforme as tecnologias e o acesso à internet de banda larga tornem-se mais acessíveis, ocorra um aumento da integração de tecnologias com os processos de aprendizagem e, consequentemente, cresça o interesse no desenvolvimento desse modelo específico de aprendizagem.

\section{AGRADECIMENTOS}

Esse trabalho recebeu apoio financeiro da Fundação de Amparo à Pesquisa do Estado do AmazonasFAPEAM em parceria com a Universidade Federal do Amazonas-UFAM. Apoio pedagógico e suporte técnico do Instituto Federal do Amazonas-IFAM e da Universidade Estadual do Amazonas-UEA. Agradecemos a professora Amanda

Meincke Melo da Universidade Federal do Pampa pelas ideias das atividades da sala, aos alunos e tutores do Curso de Pós-Graduação em Informática na Educação que participaram das atividades propostas e aos avaliadores pela parceria e contribuição da pesquisa.

\section{REFERÊNCIAS}

[1] Bishop, J. L., Verleger, M.A., The Flipped Classroom: A Survey of the Research. 120 ${ }^{\text {th }}$ ASEE Annual Conference \& Exposition - 2013 - June -Atlanta/USA.

[2] Gorman, M. "Flipping the classroom... a goldmine of research and resources keep you on your feet." 21st Century Educational Technology (2012).

[3] Herreid, C.F and Schiller, N.A. Case Studies and the Flipped Classroom. In Jornal of College Science Teaching 2013- October - New York.

[4] Lacorte, R.F. Práticas na Sala de Aula - Iberciência. Comunidad de Educadores para la Cultura Científica. 2014 - Deciembro - Toluca/México.

[5] Mendonça, A.P. Tendência e Inovações no Ensino. Editora CRV-Curitiba - Abril de 2015.

[6] Ramos, J. L. C., da Silva, R. F. P., Silva, J.C.S., Gomes, A. S. Adoção de Blended Learning: verificação do potencial de ampliação na Universidade Federal do Vale do São Francisco. Anais do XXV Simpósio Brasileiro de Informática na Educação (SBIE 2014a, Novembro - Dourados-MS).

[7] Ramos, J. L. C., Rodrigues, R. L., Gomes, A. S., Silva, J. C. S. Analisando Fatores que Afetam o Desempenho de Estudantes Iniciantes em um Curso à Distância. Anais do XXV Simpósio Brasileiro de Informática na Educação (SBIE 2014b, Novembro - Dourados-MS). 
[8] Ribeiro, G.O., Silva, T.E.V., Nunes,A.O., Pinto, F.A.P, Vasconcelos, F.H.L. Perspectivas para Reduação da Evasão em EaD a partir da Avaliação da Qualidade do Ensino Online. Anais do XXV Simpósio Brasileiro de Informática na Educação (SBIE 2014, Novembro - Dourados-MS).

[9] Teaching \& Assessment-Flipping the Class for Active Learning - Disponível em: https://teaching.wikit.itu.dk/Flipped+Classroom. Acesso em: 12 de fevereiro de 2015.

[10] Tucker, Bill. The Flipped Classroom-Online instruction at home frees class time for learning - Education Next /W in te r 2012 - July - San Francisco/USA.

[11] Valente, J.A. Aprendizagem Ativa no Ensino Superior: a proposta da sala de aula invertida.

[12] Zhang Jinlei \& Zhang Baohui. Application of Game based Learning in Flipped Classroom. Journal of Distance Education, 2013-01

[13] Zhong Xiaoliu, Song Shuqiang \& Jiao Lizhen. Instructional Design Based on the Idea of the Flipped Classroom in ICT Environment. Open Education Research, 2013-01 


\section{Capítulo 13}

Filme como recurso didático no ensino de História

\section{Mário Cézar Alves Ferreira \\ Eliane dos Santos Malheiros}

Resumo: Este trabalho trata de uma pesquisa realizada em uma escola pública de Londrina/Paraná sobre o uso de filmes como recurso didático. A análise dos dados foi desenvolvida a partir de relatos escritos por professores de História e estudantes do segundo ano do ensino médio. 0 objetivo era analisar como os dois extremos do processo de ensino aprendizagem compreendem a utilidade do cinema nas aulas de História e quais seriam, na opinião dos pesquisados, os modos de utilizar esse recurso na sala de aula. Observou-se que os objetivos perseguidos pelos professores no uso de filmes são praticamente os mesmos percebidos pelos estudantes: ilustração, motivação, complementação, fixação do conteúdo, ou simplesmente entretenimento, quando os alunos percebem a ausência de articulação com o conteúdo abordado. A maioria dos relatos aponta para a abordagem fílmica como fonte confiável, utilizada para dar credibilidade ao que foi dito pelo professor.

Palavras-chave: Cinema; Ensino de História; Estratégias de ensino e aprendizagem. 


\section{INTRODUÇÃO}

A implementação dessa proposta surgiu a partir de declarações e comentários de professores sobre o uso de filmes na sala de aula. Percebemos que havia uma expressiva procura por aparelhos de DVD e agendamentos da sala multimídia no colégio. Começamos, então, a nos questionar sobre o que os professores de História pensavam sobre o uso do cinema em sua disciplina.

A busca pelas finalidades do uso do cinema em sala de aula partiu não só da observação pela grande demanda por esse recurso no colégio, mas também pelas nossas reflexões sobre a importância que a imagem adquiriu no cotidiano de grande parte da população mundial. Diariamente somos "bombardeados" por um verdadeiro turbilhão de imagens, sobretudo as produzidas pelo cinema e televisão, que, por causarem a sensação de realidade, exercem sobre muitos de nós um certo fascínio. No entanto, a questão é que, muitas vezes, não nos damos conta de que estamos consumindo essas informações visuais sem refletirmos sobre as suas intenções.

Diante desse contexto, o professor de História tem como responsabilidade a busca por uma apropriação reflexiva dos conteúdos midiáticos. Assim, é papel da escola e dos professores a promoção de situações em que o estudante possa relacionar o conteúdo da disciplina de História com a realidade em que vive, superando, dessa forma, os modelos tradicionais de ensino, baseados na cronologia e no livro didático. Nesse sentido, faz-se necessária a reflexão sobre o uso que os professores de História fazem de um meio tão específico de produção cultural como o cinema.

A presente pesquisa, portanto, foi elaborada com o objetivo de compreender o significado do uso de filmes na disciplina de História, incluindo os estudantes de uma classe do segundo ano do ensino médio. Elaboramos, então, os seguintes objetivos específicos:

a. Analisar e discutir os objetivos dos professores ao utilizarem filmes nas aulas de História.

b. Compreender a percepção dos estudantes sobre o uso do cinema em sala de aula.

\section{FILMES COMO OBJETO PARA O ENSINO DE HISTÓRIA}

O cinema não é uma invenção recente. Seu surgimento data de pouco mais de um século, quando os irmãos franceses Louis e Auguste Lumière, em 28 de dezembro de1895, tornaram-se os pioneiros no uso do cinematógrafo, uma pequena máquina com peso pouco superior a $5 \mathrm{~kg}$. Por meio dela, realizaram, no Grand Café, em Paris, a primeira exibição de filmes curtos. Dentre eles, um com cenas de operários saindo de uma fábrica e outro com a vista de um trem chegando à estação. As cenas exibidas pelos irmãos Lumière são consideradas o marco inicial da história do cinema.

Nessa época, o cinema passou despercebido enquanto fonte potencial para o estudo da História, haja vista que os historiadores daquele período encontravam-se fortemente imbuídos pela concepção positivista, para a qual a História só poderia ser feita por meio de documentos, sobretudo os escritos.

Assim, desde a sua origem, em fins do século XIX, até os anos de 1970, o preconceito contra o cinema, enquanto documento para o estudo da História, era justificado pelo fato de suas imagens passarem por seleção e manipulação, por "uma montagem não controlável", por uma "trucagem" que "contaminava" o objeto com a subjetividade de seus realizadores (FERRO, 1992, p. 83). Para os historiadores, essa prática desqualificava o filme enquanto fonte de pesquisa, sendo o documento escrito a única fonte de pesquisa possível.

A partir de 1970, com a publicação de um conjunto de três volumes sob a direção de Jacques Le Goff e Pierre Nora, foi possível um estudo mais aprofundado da relação entre cinema e história. Os estudos apresentados por esses historiadores franceses da Escola dos Annales rompiam com os limites impostos pela escola positivista, passando a considerar como objetos e sujeitos de análise, além dos grandes fatos e personagens políticos, também as mentalidades, os costumes e as ideias de cada época. Essas novas tendências de pesquisa histórica ficaram conhecidas por Nova História.

Com as novas tendências de pesquisa histórica, o cinema também passou a ser visto como documento, sendo Marc Ferro uma das referências teóricas quando se trata do filme como fonte para o estudo da História. Para ele:

[...] o filme pode tornar-se um documento para a pesquisa histórica na medida em que articula ao contexto histórico e social que o produziu um conjunto de elementos intrínsecos à própria expressão cinematográfica. Esta definição é o 
ponto de partida que permite tirar o filme do terreno das evidências: ele passa a ser visto como uma construção que, como tal, altera a realidade através e entre a imagem, a palavra, o som e o movimento (FERRO, 1992, p. 86).

Ferro (2010) considera que o filme é um testemunho sobre a sociedade que o produziu e que, por isso, deve ser analisado em conjunto com o seu contexto de produção. Portanto, de acordo com Ferro, mesmo o filme ficcional de tema histórico sempre dirá mais da sociedade que o produziu do que propriamente do período que quis representar. Assim, conforme o autor, a análise fílmica deve contemplar, além dos componentes fílmicos, como: "a narrativa, o cenário, o texto", também "as relações do filme com o que não é filme, o autor, a produção, o público, a crítica, o regime” (FERRO, 1992, p 33).

Sendo assim, tanto o historiador como o professor de História devem estar cientes de que os filmes, ao serem produzidos, sofrem interferências das sociedades em que foram produzidos. Essas interferências são sempre de ordem histórica, política, ideológica e cultural. Os filmes comerciais, por exemplo, são sempre produzidos com vista a conquistar a maior aceitação possível da sociedade à qual destina. É nesse sentido que o cinema sofre interferências da sociedade em foi produzido.

Por outro lado, é necessário considerar também os efeitos que o cinema produz na sociedade. Rocha (1993, p.75) destaca que os filmes influenciam e interferem na história de duas maneiras: primeira, por apresentarem posicionamentos diante da sociedade que o gerou; segunda, quando exibidos em outras nações, transferem valores e ideias, interferindo, portanto, na sua ordem social.

Ao utilizar o cinema como documento, é essencial que o professor tenha um domínio básico da linguagem cinematográfica. Conhecer a variedade de elementos usados de maneira intencional para causar sensações, sentimentos e emoções ajuda o professor a explorar ao máximo as potencialidades do recurso fílmico junto aos alunos. Permite compreender, por exemplo, que aquilo que sentimos ao assistir a um filme não ocorre de maneira aleatória. As sensações e sentimentos são causados por uma variedade de pequenos elementos, geralmente escolhidos de maneira intencional para atender a objetivos sensoriais. Para os estudantes, o cinema apresenta imenso potencial para o ensino da História, porém deve-se superar a ideia de que os filmes históricos representam fielmente os fatos tal como ocorreram. Os Parâmetros Curriculares Nacionais para o Ensino de História (PCNs) (BRASIL, 1998, p. 88) alertam para os cuidados que o professor deve ter em relação ao seu tratamento em sala de aula:

No caso de trabalho didático com filmes que abordam temas históricos é comum a preocupação do professor em verificar se a reconstrução das vestimentas é ou não precisa, se os cenários são ou não fieis [...] um filme abordando temas históricos ou de ficção pode ser trabalhado como documento se o professor tiver a consciência de que as informações extraídas estão mais diretamente ligadas à época em que a película foi produzida do que a época que o retrata [...]. Para evidenciar o quanto os filmes estão impregnados de valores da época com base na qual foram produzidos tornam-se valiosas as situações em que o professor escolha dois ou três filmes que retratam um mesmo período histórico e com os alunos estabeleça relações e distinções, se possuem divergências ou concordâncias no tratamento do tema [...]. Todo o esforço do professor pode ser no sentido de mostrar que, à maneira do conhecimento histórico, o filme também é produzido, irradiando sentidos e verdades plurais (BRASIL, 1998, p. 88).

Napolitano (2011) recomenda que o professor estabeleça parâmetros de comparação entre as versões histórica, fílmica e sobre o fato a ser estudado por meio de textos ou documentos de linguagens distintas. Esse tipo de abordagem visa a evitar que os estudantes sejam totalmente seduzidos pelas representações e valores veiculados, assimilando-as como verdades inquestionáveis. 0 autor sugere que, ao utilizar o filme, o professor

[...] procure confrontar a abordagem ou os problemas propostos com base no tema em dois planos: a) a abordagem do(s) filme (s) em si; b) a comparação do (s) filme (s) com outros textos e documentos em outra linguagem (escrita, sonora, iconográfica). Esse tipo de abordagem comparativa é especialmente útil para provocar no aluno certo distanciamento do impacto inicial, de ordem cognitiva e ideológica, que os filmes costumam causar nos espectadores mais envolvidos. 0 professor deve comentar e problematizar o filme sob uma óptica interdisciplinar: ciências da natureza (as explicações e teorias cientificas veiculadas), códigos e linguagens (as várias formas de comunicação e 
representação simbólica catalisadas no filme), ciências humanas e temas transversais (as várias representações e os vários contextos históricos, os agentes e as instituições sociais, os princípios e os valores ideológicos). Estes quatro grandes conjuntos estão presentes em quase todos os filmes e tendem a se sobrepor em relação à abordagem escolar tradicional, pois o cinema tem a vantagem de possuir uma linguagem e um poder de convencimento mais sedutores, dada a sua natureza artística e "mágica". [...] (NAPOLITANO, 2011, p. 86)

Durante a análise, chamar atenção para os detalhes do figurino, o modo como os grupos estão caracterizados, discutindo a intenção da trilha sonora e do uso de determinados sons pelo diretor, assim como para a fotografia, enquadramentos, posições de câmera e as mensagens que elas constroem. Sugerese conduzir e/ou provocar o estudante frente à visualização das mensagens veiculadas, incentivando questionamentos sobre as suas intencionalidades.

Esse tipo de atividade ajuda a eliminar o efeito de super-representação que filme provoca, sobretudo nos alunos mais ingênuos. Contribui também para a percepção dos alunos sobre a distinção entre o ofício do historiador e o do cineasta. Mostra que ambos se apropriam de personagens e fatos históricos com objetivos distintos. No cinema, os personagens e fatos históricos sofrem adaptações, distorções e anacronismos que, muitas vezes, se contrapõem às pesquisas historiográficas, até para deixar a história mais "palatável" ao grande público, tornando-a mais dinâmica e emocionante.

\section{A ORGANIZAÇÃO DA PESQUISA}

A pesquisa foi realizada com 24 estudantes do ensino médio ( $2^{\circ}$ ano) e cinco professores de História, de uma escola pública de Londrina, em 2015. As questões que impulsionaram nossas reflexões referem-se à compreensão de professores e estudantes sobre a inclusão do cinema nas aulas de História e de como, na visão de ambos, o filme é utilizado na sala de aula. Utilizamos como instrumento de pesquisa a pergunta: para que serve o uso do filme nas aulas de história?

Para a análise dos dados, os cinco professores que participaram da pesquisa foram discriminados como P1, P2, P3, P4 e P5 e os 24 alunos como A1, A2, A3 até o A24. Ao término da investigação foram identificadas várias recorrências que foram, em seguida, separadas em categorias, conforme mostra o Quadro 1.

Quadro 1: categorias identificadas durante a pesquisa

\begin{tabular}{|l|c|c|c|c|}
\multicolumn{1}{c}{ Categorias } & \multicolumn{2}{c}{ Professores } & \multicolumn{3}{c|}{ Alunos } \\
& $\mathrm{N}-$ & $\%$ & № & $\%$ \\
\hline 1) Ilustração & 2 & 40 & 10 & 41,6 \\
\hline 2) Motivação & 1 & 20 & 4 & 16,6 \\
\hline 3) Complementação & 1 & 20 & 6 & 25 \\
\hline 4) Exibição de filmes "sem conexão com o conteúdo" & 0 & 0 & 4 & 16,6 \\
\hline 5) O filme como documento para o Ensino de História & 1 & 20 & 0 & 0 \\
\hline
\end{tabular}

Ao término da análise foram identificadas cinco categorias: ilustração, motivação, complementação, o estudo do filme enquanto documento para o estudo da História e a ausência de contextualização do filme. Essa última categoria, como veremos adiante, gera no aluno a percepção de tempo desperdiçado em relação ao conteúdo da disciplina. Todas elas serão analisadas separadamente a seguir.

Verificaremos as considerações de professores e alunos para a pergunta: para que serve o uso do filme nas aulas de história?

a) 0 filme como ilustração e fixação dos conteúdos de História: uma das tendências observadas em parte dos professores e estudantes pesquisados é a de conceber o filme apenas como ilustração do tema que está sendo abordado. 
Quadro 2: Respostas referentes à categoria ilustração Para que serve o uso do filme nas aulas de história?

\begin{tabular}{|c|l|}
\hline P1 & $\begin{array}{l}\text { Para que serve o uso do filme nas aulas de história? } \\
\text { "Penso que o filme é um suporte que deve ser melhor aproveitado para o ensino de História porque é } \\
\text { majoritariamente no nível teórico". }\end{array}$ \\
\hline P2 & $\begin{array}{l}\text { "o aluno é muito visual, aprende mais quando tem acesso a imagens que ilustrem os conteúdos } \\
\text { estudados". }\end{array}$ \\
\hline A1 & $\begin{array}{l}\text { "O filme é uma fonte de informação importante, pois lendo um texto a pessoa, às vezes, não tem muita } \\
\text { imaginação para visualizar o que se está lendo, e o filme entra com essa possibilidade de visão sobre um } \\
\text { determinado assunto". }\end{array}$ \\
\hline A2 & "Para ter uma visão de como era nos tempos antigos" \\
\hline A3 & "Para [...] mostrar um pouco da História antigamente" \\
\hline A4 & $\begin{array}{l}\text { "Acho que um dos motivos é que serve para o aluno visualizar o que foi explicado em sala de aula desde } \\
\text { então [...]". }\end{array}$ \\
\hline A5 & "Para mostrar melhor para nós o conteúdo". \\
\hline A6 & "[..] serve para ajudar [...] a guardar a história e o que ela conta [...]" \\
\hline A7 & "Serve para adquirir novos conhecimentos e fixar aqueles que já temos" \\
\hline A8 & "[...] fica mais fácil de gravar o que aconteceu ou que a professora quis passar", \\
\hline A9 & "[..] ter uma ideia de como eram as pessoas antigamente” \\
\hline A10 & "[...] para saber mais daquilo que passou, aquilo que um dia foi importante [...]" \\
\hline
\end{tabular}

Fonte: dados da pesquisa

O Quadro 1 permite observar na resposta do professor P1 a ausência de preocupação com aspectos tecnológicos, época da produção, regime político e interesses econômicos sob os quais a obra foi produzida, tampouco sobre a comparação de filmes que abordam a mesma temática.

Assim, o filme é tratado como um recurso que permite ao estudante ver a História, conforme o comentário do professor P2, que deixa clara a visão de que o cinema serve para comprovar o discurso desenvolvido em sala de aula, tornando-se, assim, a única possibilidade de visualização da História.

Tal perspectiva tem reflexo direto no olhar dos estudantes que em seus comentários apontam para a ideia de que o cinema facilita a compreensão do tema abordado, aproximando-os de forma ilustrativa da história estudada e da ideia dos dois professores analisados. Além do mais, é possível observar que esse viés reforça a ideia de fidelidade de caracterização da sociedade e do tempo representados pelo filme. Como se o cinema pudesse ser produzido sem interferências ideológicas.

Nesse sentido, consideramos que esse tipo de estratégia torna-se um obstáculo ao desenvolvimento crítico da consciência histórica do estudante. Por falta de formação adequada, nem professores nem estudantes, consequentemente, conseguem desenvolver a consciência de que um filme, seja ele histórico ou não, é também uma fonte histórica e que, por ser uma fonte, possui maior potencial para responder questões sobre a época em que foi produzido do para ilustrar determinado tema.

b) 0 filme como instrumento motivacional: na sequência o Quadro 2 aponta uma outra justificativa muito comum, observada na fala de um dos professores e de alguns alunos, sobre o uso do cinema como elemento motivacional para as aulas de História.

Quadro 2: Respostas referentes à categoria motivação

\begin{tabular}{|c|c|}
\hline P3 & $\begin{array}{c}\text { "Nos dias de hoje o professor tem um grande desafio: tornar sua aula dinâmica, uma vez que temos que } \\
\text { competir com celulares, redes sociais e "sinal de internet facilitado". }\end{array}$ \\
\hline A11 & $\begin{array}{c}\text { "O filme serve para ter uma aula mais dinâmica, para não ficar apenas na explicação, não ter apenas } \\
\text { uma aula cansativa em que os alunos não interagem. Com o filme a aula fica mais moderna e os alunos } \\
\text { se interessam mais pelo assunto". }\end{array}$ \\
\hline A12 & "Para entreter, ajuda a entender mais a atividade". \\
\hline A13 & "Para ser uma aula mais atrativa, é uma coisa diferente, porém se torna interessante e menos cansativa" \\
\hline A14 & "Serve para mostrar como era naquela época e por diversão". \\
\hline
\end{tabular}

Fonte: dados da pesquisa. 
Apesar de não afirmar diretamente que o filme serve para oferecer aos estudantes um momento de descontração, o que fica subentendido no comentário do professor P3 é que o seu uso torna as aulas mais agradáveis, ao substituir o desinteresse pela palavra escrita. Nesse caso, conforme argumenta o professor, o simples uso de uma tecnologia da informação à qual os jovens estão acostumados basta para motivá-los. O uso de um vídeo em sala de aula, então, fica restrito simplesmente a esse objetivo, que é o de tornar a aula mais interessante.

Ao compararmos o comentário do professor P3 aos dos estudantes é possível inferir que, embora os alunos gostem de assistir, não estão habituados a análises mais profundas a respeito do cinema, limitandose apenas a discussões superficiais. Desse modo, os estudantes mostram-se mais confortáveis ao verem a história do tema tratado por meio da representação fílmica, que julgam ser fiel à fala do professor e à história contada no livro.

c) 0 filme como discussão e complementação das aulas de História: o objetivo do recurso fílmico, nessa categoria, é complementar algum assunto abordado.

Quadro 3 - Respostas à pergunta: para que serve o uso do filme nas aulas de história?

\begin{tabular}{|c|l|}
\hline P4 & $\begin{array}{l}\text { "O filme serve para complementar o conteúdo em desenvolvimento, fornecendo informações para a } \\
\text { reflexão do estudante acerca do assunto". }\end{array}$ \\
\hline A15 & $\begin{array}{l}\text { "O uso do filme serve como um complemento, uma base para que o aluno compreenda melhor o } \\
\text { assunto" }\end{array}$ \\
\hline A16 & "Para completar o assunto em sala e aprofundar nos temas estudados" \\
\hline A17 & "Abordar os fatos que têm a ver com o conteúdo, ou seja, um complemento" \\
\hline A18 & "Para termos uma aula mais interessante e complexa" \\
\hline A19 & "Para um melhor esclarecimento da matéria" \\
\hline A20 & "Para amplo conhecimento, auxilio na compreensão da aula e para complementar a aula" \\
\hline
\end{tabular}

Fonte: dados da pesquisa.

Aqui, como na maioria das respostas dos estudantes e professores pesquisados, observa-se a ideia de relacionar o filme diretamente ao tema tratado em sala de aula. As respostas não indicam nenhum cuidado com as especificidades da linguagem cinematográfica, possíveis anacronismos presentes na trama, diálogos, figurino ou trilha sonora. Observa-se, também, a ausência de menção à comparação de filmes relacionados a um mesmo assunto, o que seria um tipo de atividade muito mais profícua para a reflexão sobre diferentes representações.

d) A exibição de filmes "sem conexão com o conteúdo": esse ponto fica evidente nos comentários do Quadro 4.

Quadro 4 - Respostas à pergunta: para que serve o uso do filme nas aulas de história?

\begin{tabular}{|c|l|}
\hline P5 & $\begin{array}{l}\text { "O filme serve como um documento para o estudo da história, contudo, se não for contextualizado e } \\
\text { analisado, segundo as metodologias empregadas para analisar filmes como fonte histórica, seu uso pode } \\
\text { se tornar uma 'aula de divertimento'. Se o filme se não for devidamente explicado e correlacionado com } \\
\text { o conteúdo estudado, os alunos podem acreditar que o professor está passando filme para 'matar tempo' } \\
\text { ". }\end{array}$ \\
\hline A21 & "A aula de história com filmes fica mais interessante, mas tem como desvantagem as aulas perdidas". \\
\hline A22 & $\begin{array}{l}\text { "Ajuda os alunos a participarem mais das aulas, as desvantagem são os conteúdos perdidos por causa } \\
\text { das aulas com filmes" }\end{array}$ \\
\hline A23 & "A aula com filmes é uma aula diferente, sem teoria, mas tem como desvantagem a bagunça". \\
\hline A24 & "As aulas ficam mais legais, mas perde-se muito tempo com os filmes". \\
\hline
\end{tabular}

Fonte: dados da pesquisa.

As respostas sugerem a utilização de filmes sem que fique claro para os estudantes os objetivos do seu uso para aprendizagem e a sua vinculação ao conteúdo. Moran $(1995$, p.3), acerca desse assunto, menciona que o estudante percebe quando o professor faz uso de um vídeo a fim de parecer que dá aula, podendo "até concordar na hora, mas discorda do seu mau uso".

No depoimento registrado, nota-se que a professora P5 possui conhecimento sobre o uso adequado do cinema nas aulas de História. Aponta para a necessidade de contextualizar a obra em seu período de produção, analisando-a segundo as metodologias específicas para a análise de filmes enquanto fonte histórica. Por fim, chama a atenção para a necessidade de articulação entre o filme e o conteúdo estudado. 
Nesse sentido, Napolitano sugere que "o planejamento com filmes deve obedecer a uma escolha voltada para os interesses da disciplina, levando em conta a cultura geral e audiovisual da classe e o lugar que o filme ocupa na história e linguagem cinematográfica" (NAPOLITANO, 2011, p. 80)

\section{CONSIDERAÇõES FINAIS}

Esta pesquisa buscou compreender os dois extremos de um mesmo processo: como o cinema é utilizado pelos professores do ensino de História e quais são as leituras feitas pelos estudantes sobre a promoção de tais estratégias no processo de ensino aprendizagem. 0 estudo mostrou que as práticas docentes não consideram o uso de metodologias específicas para a análise do filme enquanto fonte em potencial para o ensino crítico e reflexivo de História.

Práticas que deveriam contribuir para o esclarecimento e a emancipação plena dos estudantes são reduzidas à projeção de filmes com o intuito de motivar, complementar, ilustrar e fixar determinado conhecimento. Tais usos revelam, em grande parte, a permanência de uma visão ingênua sobre o trabalho com cinema em sala de aula. Sobretudo, no que se refere aos filmes que apresentam, em suas temáticas, fatos históricos e que são, por isso, equivocadamente compreendidos como fiéis ao que foi pesquisado por historiadores profissionais. Por esse ponto de vista, a História representada pelo cinema seria a reprodução fidedigna dos livros e manuais didáticos da disciplina.

Nas falas dos alunos e de professores verifica-se que a maior parte dos processos didáticos desencadeados em nada contribuiu para a formação da consciência histórica. Suas práticas são pautadas pela busca objetiva de uma pretensa "verdade histórica". Os resultados atestam, em sua maioria, a reduzida formação docente para lidar de forma mais sofisticada e complexa com o cinema no ambiente escolar, tendo em vista a explícita ausência de conhecimentos sobre as especificidades do filme enquanto fonte histórica.

Os objetivos perseguidos pelos professores no uso do cinema são os mesmo apontados pelos estudantes: ilustração, motivação, complementação, fixação do conteúdo ou simples entretenimento, às vezes, com pouca ou nenhuma conexão com o conteúdo abordado. A partir desse modo de perceber as imagens poderíamos refletir sobre nossa responsabilidade, enquanto professores, pela visão simplista e naturalizada dos alunos acerca das imagens. Os filmes são abordados como fonte confiável, utilizada para dar credibilidade ao que foi dito pelo professor, acreditando-se que os estudantes tendem a aceitar e a compreender melhor o tema tratado.

Nesse sentido, é nosso papel a busca por conhecimento acerca do tratamento das imagens em sala de aula. A aquisição de tal competência possibilitará a construção de práticas de mediação mais críticas e poderá levar os alunos a serem competentes para analisar e compreender mensagens e aspectos artificiais ocultos em um filme, assim como a sua inserção na vida cotidiana.

\section{REFERÊNCIAS}

[1] Brasil. Secretaria de Educação Fundamental. Parâmetros Curriculares Nacionais: história. Brasília: MEC/SEF, 1998.

[2] Ferro, Marc. Cinema e História. Tradução de Flavia Nascimento. Rio de Janeiro: Paz e Terra, 1992.

[3] Moran, José Manuel. O vídeo na sala de aula. São Paulo: Comunicação e Educação. Eca. Ed Moderna. p. 27-35. jan/abr, 1995.

[4] Napolitano, Marcos. Como usar o cinema em sala de aula. 5. ed. São Paulo: Contexto, 2011.

[5] Rocha, Antônio Penalves. 0 filme: um recurso didático no ensino de história? In: Falcão, Antônio Rebouças; Bruzzo, Cristina. Coletânea: Lições com o cinema. São Paulo: FDE, 1993. p. 69-86. 


\title{
Capítulo 14
}

Reflexões do filme Escritores da liberdade a partir de uma prática pegagógica

\author{
Eliane Picão da Silva Costa \\ Yasmin Coelho Figueiredo Manfredo \\ Lucila Akiko Nagashima
}

Resumo: 0 presente artigo aponta uma análise do filme Escritores da Liberdade com o objetivo de investigar uma possível contribuição na prática pedagógica. Pode-se dizer que o conhecimento é concretizado através da interação professor-aluno, de modo a corroborar na formação da identidade do educando e no processo de aprendizagem. Nesse sentido, o filme analisado apresenta, dentro de sua perspectiva, a narração de como a interação pedagógica aprimora vínculos afetivos e promove valores entre os envolvidos. Merece destaque a prática pedagógica realizada pela professora Erin Gruwell, que na tentativa de envolver os alunos a fim de que estes se identificassem e tivessem maior interesse pelas aulas, criou um projeto para a leitura do "Diário de Anne Frank" e elaborar seu próprio diário, contando tudo que quisessem: seus sentimentos, pensamentos, o que já havia se passado na sua vida e o que sonhavam. A partir de então, os educandos uniram suas histórias e produziram um livro, superando todas as expectativas e mudando suas histórias de vida. A metodologia utilizada é bibliográfica. Diante disso, o educador necessita ter ciência de que todos possuem limitações na busca do conhecimento, o que favorece um ensino sem preconceitos. 0 filme Escritores da Liberdade é extremamente rico em seu conteúdo, surpreendendo não somente pelo fato de ser baseado em fatos reais, mas pela reflexão que nos remete a história da educadora que fez a diferença, e dos educandos, que tanto ensinaram e aprenderam, mesmo em face de tantas adversidades. Para tanto, através desta análise, perguntamos: será que como educadores estamos somente imbuídos em "darmos aulas" ou sermos "mediadores" do conhecimento?

Palavras-chave: Formação de professores; Prática pedagógica; Indisciplina Artigo já publicado nos Anais do evento Educere (XII Congresso Nacional de Educação) 


\section{INTRODUÇÃO}

No campo da educação é comum se deparar com colegas de profissão que se queixam da dificuldade que apresentam em dominar as práticas pedagógicas, através das quais o professor encontre caminhos que facilite transferir o discurso pedagógico da teoria para a prática. Através do filme Escritores da Liberdade é possível vislumbrar o "fazer" com excelência, sendo uma sugestão a ser considerada por cada educador, a fim de que reflita não somente sobre sua prática pedagógica, bem como o sistema de ensino, mas acerca da sociedade em que estamos inseridos.

O filme, que é baseado em uma história real, traz o relato da professora Erin Gruwell. Ela começa a dar aulas em uma turma de alunos problemáticos que são divididos em gangues e etnias criados em um ambiente violento e excludente, contribuindo assim para a indisciplina no espaço acadêmico. A professora novata decide ajudá-los. Por várias vezes ela é desmotivada por seus colegas de trabalho e não tem incentivo algum por parte da direção da escola, mas ainda assim ela vai além, começa a fazer algumas atividades na tentativa de envolver os alunos a fim de que se identificassem e tivessem maior interesse pelas aulas.

Segundo Silva (2007), para diminuir a indisciplina, preconceito construído pela diversidade na escola, é importante a atuação de docentes capacitados para trabalharem na formação do aluno.

O filme narra como a relação pedagógica viabiliza o aprimoramento de vínculos afetivos, imprimindo a importância na interação do docente com o aluno. Pois foi através dessa interação professor/aluno que a professora desenvolveu um projeto para que seus alunos lessem "O Diário de Anne Frank" e que, após a leitura, escrevessem seu próprio diário, contando tudo o que quisessem concernente às suas vidas. Por fim houve uma mudança muito relevante no desempenho de toda a turma, que a partir de então fazia de tudo para que a sala não perdesse essa tão harmoniosa relação.

Com base na concepção de autores como Silva (2007), Carvalho (2001) e outros, discute-se a importância da prática pedagógica no processo de ensino-aprendizagem.

Nessa perspectiva, o trabalho analisa no interior da narrativa do filme como a interação pedagógica pode promover vínculos, agregar valores e discutir uma abordagem pedagógica adotada pela professora, em que a metodologia aplicada favorece o aprimoramento dos vínculos afetivos e promoção da identidade, gerando interesse no processo de ensino.

\section{A PRÁTICA PEDAGÓGICA DO FILME ESCRITORES DA LIBERDADE}

O filme Escritores da Liberdade demonstra os desafios da "Erin Gruwell", professora de Inglês e Literatura, que leciona numa sala de 1o ano do Ensino Médio numa escola de periferia em Los Angeles, Califórnia. Sua sala de aula é constituída de alunos adolescentes com problemas socioculturais diversos, provenientes de uma infância frustrada.

A professora, repleta de expectativas e empolgação inicial, encontra diversos problemas com os seus discentes, tais como: indisciplina, violência, desmotivação e discriminação. A maioria dos alunos dessa turma era envolvida com gangues e pertencia a famílias desestruturadas, sendo totalmente discriminados, tanto dentro como fora do ambiente escolar.

Conforme Garcia (2006), a indisciplina, como também a violência têm sido muito questionadas no espaço acadêmico, o qual requer mudanças para promover a socialização entre o docente e discente.

No entanto, esses discentes rotulados e marginalizados conforme mostram as cenas do filme, mesmo que desacreditados no tocante ao ensino, ao encontrarem uma professora com pouca experiência, mas com muita força de vontade, são influenciados por suas estratégias de ensino.Lidar com a indisciplina da tão temida sala 203, uma sala multiculturalista constituída por diversas gangues, tornava ainda mais difícil o ensino.

Para Garcia (2006, p. 102):

[...] define-se indisciplina como a incongruência entre os critérios e expectativas assumidos pela escola (que supostamente refletem o pensamento da comunidade escolar) em termos de comportamento, atitudes, socialização, relacionamentos e desenvolvimento cognitivo, e aquilo que demonstram os estudantes (GARCIA, 2006, p.102). 
Nesse sentido a indisciplina provoca grandes problemas na escola, cabendo ao professor desenvolver estratégias para lidar com a realidade sociocultural através de mudanças em sua metodologia, de modo a favorecer que os educandos aprendam a se socializar e interagir em sala de aula.

Libâneo (1999) afirma que um ensino centrado na realidade sociocultural dos educandos está relacionado a uma educação transformadora da realidade do sujeito. Tudo o que a docente Erin Gruwell planejava não tinha significado para os alunos. No entanto, mesmo com tantos obstáculos, Erin conseguiu reverter todo o conflito ao fazer uso de novas alternativas em sua metodologia e partir do conhecimento prévio de cada educando.

Conforme Oliveira (2008), o conhecimento prévio está relacionado ao conteúdo do ensino para conseguir realizar uma aprendizagem de forma significativa. Dessa forma, a docente começou planejar suas aulas através da realidade dos alunos, e com isso utilizava, músicas, jogos, passeios e o diálogo, no intuito de aumentar a autoestima para os mesmos perceberem o mundo de forma diferente.

Depois que a docente conseguiu despertar a atenção dos adolescentes, procurou conhecer a história de vida dos seus alunos, perante a qual começou a trabalhar valores, identidade, sentimentos, sensibilizando a tolerância, a discriminação e o preconceito, o que contribuiu para minimizar a indisciplina e a violência, de forma a proporcionar maior integração e participação dos alunos durante a aula.

Na concepção de Libâneo (1999), é importante o professor introduzir os conteúdos pautando-se na realidade do educando, de modo a inserir conteúdos significativos que contribuam para a inserção do discente no meio social, porém é fundamental que o conteúdo tenha significado para ajudar na formação do acadêmico.

Vale ressaltar que o educador não transmite apenas informações ou faz questionamentos, ele também deve ouvir os alunos de forma a entender suas carências e suas dificuldades. Nesse sentido, caberá ao professor diferenciar severidade e respeito, já que o processo de ensino ao mesmo tempo em que direciona a aprendizagem em suas atividades deve ter como objetivo orientar as atividades autônomas e independentes dos alunos estabelecendo normas e deixando bem claro aos alunos o que se espera deles (LIBÂNEO, 1999).

De acordo com o autor é importante o professor deixar o aluno se expressar de modo a participar durante a aula para desenvolver sua autonomia.

Silva (2007) destaca que o aluno sente mais interesse pelo ensino quando é incentivado e motivado, por isso o docente precisa despertar a curiosidade dos educandos e acompanhar o desenvolvimento de suas atividades.

Nas cenas do filmea professora surpreendeu seus alunos trazendo atividades novas na sua metodologia na intenção de conquistar a confiança dos seus pupilos. Ao perceber que os seus educandos desconheciam a tragédia do Holocausto, ela se valeu de algumas estratégias no intuito de conscientizá-los a respeito dos horrores que a segregação racial pode causar. Mostrou então para os seus discentes o que realmente seria uma gangue, a qual ela comparou com o nazismo de Hitler ao querer exterminar negros e judeus, a fim de criar uma raça ariana que ele considerava "pura". E através desse método de ensino que ela considerou providencial em seu ambiente escolar, foi ganhando confiança e os alunos começaram a se sentir aceitos e estimulados a alcançarem os seus objetivos.

Segundo Hillal (1995), o docente que realmente quer ser um educador, precisa criar na sua sala de aula atividades diferenciadas baseadas na realidade dos alunos, necessita compreender que a aprendizagem é uma atividade criativa e construtiva. 0 professor precisa conhecer seus alunos, no intuito de interagir nas suas dificuldades para ajudá-los, procurando sempre conduzi-los a trilharem o caminho do bem. 0 educador como mediador do conhecimento precisa fazer um gesto significativo para a aprendizagem, promovendo o desenvolvimento intelectual e acadêmico do aluno.

Para Freire (1996), é fundamental reconhecer a identidade cultural dos educandos, de forma a considerar o respeito essencial na prática educativa. Portanto, um simples gesto do docente pode contribuir por toda a vida de um aluno.

Nesse sentido, a educadora Erin, interpretada pela atriz Hillary Swank, mesmo com a falta de apoio dos envolvidos com a escola, como direção e suporte pedagógico, não desanimou, pelo contrário, procurava propostas inovadoras, investindo em leituras significativas. Todas as adversidades e desafios, portanto, serviram como um estímulo para a superação e enfrentamento das dificuldades. Um de seus projetos foi o "Diário de Anne Frank", por meio do qual os alunos escreviam tudo o que sentiam e vivenciaram, tanto fatos negativos como positivos. A docente resolveu ter outros empregos para poder custear as aulas- 
passeio culturais à sua turma, assim como a leitura dos livros mais seletos que a escola se recusava a ofertar, com o propósito de estimular, não só a leitura de boas obras, como também a escrita de cartas. Após a leitura do livro: "O Diário de Anne Frank" pelos alunos, Erin pediu para que eles escrevessem uma carta à Miep Gies, mulher que protegeu Anne Frank dos nazistas durante o Holocausto e que guardou o seu diário durante o período conflitivo da Segunda Guerra Mundial. Com este projeto os discentes tiveram uma grande conquista em suas vidas, pois as suas produções resultaram em um livro intitulado "O Diário dos Escritores da Liberdade", que foi publicado nos Estados Unidos no ano de 1999.

Mesmo sendo tradicionalista a escola onde lecionava a Senhora G, como era carinhosamente chamada pelos alunos, enfatizou atividades pedagógicas de acordo com a realidade cultural e social através dos conhecimentos preexistentes trazidos pelos mesmos. A docente, através de sua filosofia educacional e por acreditar que a sala de aula é um lugar propício para acontecerem as verdadeiras mudanças, conseguiu transformar uma turma marginalizada, rotulada e intolerante em pessoas autônomas, confiantes, compromissadas e capazes de mudar a sua realidade.

\subsection{DIÁLOGO: UMA CONTRIBUIÇÃO NA RELAÇÃO PROFESSOR - ALUNO}

0 filme retrata conflitos geradores de agressividade e violência em uma escola situada em Los AngelesCalifórnia. Tais aspectos são também características de muitas escolas brasileiras, como a indisciplina, comportamentos agressivos, assim como atitudes preconceituosas e intolerantes que geram a exclusão, o abandono escolar e dificultam a interação professor-aluno. Nesse sentido, a escola é um ambiente que tem a função de promover as relações sociais, bem como contribuir para uma melhor convivência por meio de uma aprendizagem significativa.

De acordo com o psicólogo norte-americano David Paul Ausubel (1918-2008), o conteúdo escolar precisa ser significativo ao aluno a fim de que a aprendizagem não se torne apenas um processo mecânico, segundo o qual o conhecimento não é de fato assimilado. Conforme a teoria da aprendizagem significativa de Ausubel (1982), há necessidade da valorização dos conhecimentos prévios dos educandos para que os mesmos sejam capazes de construir estruturas mentais, levando-se em consideração a realidade em que o discente está inserido. Ausubel (1982) afirma que a aprendizagem significativa ocorre à medida que o novo conteúdo esteja relacionado com o seu conhecimento prévio (BARON, 2002).

A professora Erin Gruwell enfrentou todos os obstáculos surgidos acreditando que poderia mudar a realidade da sala de aula. Para isso, ela investiu em uma aprendizagem significativa ao considerar a realidade dos seus estudantes, partindo do conhecimento prévio que sua turma tinha sobre si mesma, conquistando a confiança e o respeito de cada um para transformar a realidade social e cultural.

De acordo com Oliveira (2008), a relação social é um dos principais meios para o desenvolvimento das pessoas. A relação entre professor e alunos na sala de aula precisa ser positiva e vivenciada de forma que preencha as necessidades dos alunos na aprendizagem.

Sendo assim, além do professor aplicar uma metodologia que favoreça sua relação com o aluno, também é fundamental que ocorra de forma dialógica para dar mais significado à aprendizagem. E esse foi um ponto muito bem destacado no filme, o qual contribuiu para a professora conhecer melhor seus alunos com a finalidade de resgatar valores e quebrar estereótipos, cuja função do docente é a de mediador do conhecimento.

Santos (2009) menciona que a função do docente como mediador está relacionada a diversos aspectos, havendo, dessa forma, a necessidade de promover o diálogo e a interação para que os alunos participem da aula. 0 professor precisa ser problematizador no processo de conhecimento de modo a orientar e coordenar as atividades para que os alunos possam desenvolver seu potencial, expressando-se de maneira que o aluno entenda o conteúdo proposto. Torna-se viável que o educador estimule o aluno a pensar por si mesmo, pois dessa forma estará contribuindo no desenvolvimento da autonomia intelectual do discente.

Segundo Silva (2007), na escola o ensino está relacionado com a forma de o professor interagir com os seus educandos. Nesse sentido a forma de se relacionar ajuda no processo da aprendizagem favorecendo a construção do conhecimento. Diante disso, o professor precisa ser o mediador de forma a possibilitar que a sua prática pedagógica seja aplicada de maneira contextualizada conforme a realidade cultural dos discentes, promovendo então, o desempenho dos alunos na aprendizagem através do diálogo.

Desse modo, para que o ensino e a aprendizagem sejam significativos na vida do ser humano, a escola precisa trabalhar pautada na realidade do aluno através de um conhecimento prévio, fato mostrado brilhantemente no filme. Moreira (2006) declara que o ensino e a aprendizagem estão relacionados com 
conteúdos, escola, docente e discente, já que esses elementos têm suas funções para uma melhor concretização da educação, promovendo a qualidade do ensino.

Libâneo (1999a), afirma que a interação professor-aluno é importante estar presente na didática do professor no intuito de alcançar os objetivos na aprendizagem, tais como a transmissão e a assimilação dos conhecimentos, proporcionando uma melhor aprendizagem na vida do aluno. Este foi um dos métodos de ensino habilmente utilizado pela professora Erin para conquistar a confiança dos alunos facilitando a transmissão e assimilação dos conteúdos. Visto que a transmissão e assimilação precisam ser trabalhadas em conjunto, através de atividades individuais, coletivas, bem como atividades fora da sala de aula para que tenham incentivos e aprendam com mais facilidade.

Conforme Cordeiro (2007), o ensino e a aprendizagem fazem parte de uma interação social. Tais interações estão relacionadas aos conhecimentos dos educadores e educandos e podem ser reconhecidas como relações pedagógicas.

0 autor evidencia que a relação pedagógica está relacionada ao diálogo, promovendo significado no ambiente escolar onde o diálogo contribui no fortalecimento de vínculos.

Na concepção de Rego (2001), para que haja um convívio harmônico na vida social, faz-se de extrema importância o cumprimento de regras e normas com a função de nortear as relações de forma dialógica:

A vida em sociedade pressupõe a criação e o cumprimento de regras e preceitos capazes de nortear as relações, possibilitar o diálogo, a cooperação e a troca entre membros deste grupo social. A escola por sua vez, também precisa de regras e normas orientadoras do seu funcionamento e da convivência entre os diferentes que nela atuam. Nesse sentido, as normas deixam de ser vistas como prescrições castradoras, e passam a ser vistas como condição necessária ao convívio social (REGO, 2001, p. 86).

Para Freire (1996a), o diálogo não transmite conteúdos, mas possibilita a construção do conhecimento, sendo um agente transformador do meio cultural no qual está inserido.

Nas palavras de Hillal (1995), o professor precisa se integrar ao grupo dos alunos promovendo o diálogo, no intuito da obtenção de um bom relacionamento entre ambos, de modo a torná-los críticos e construtivos para uma aprendizagem concreta e satisfatória.

Considerando que os educadores e os alunos são sujeitos construtores de uma aprendizagem recíproca, o diálogo torna-se de fundamental importância, pois é através deste que o discente passa a construir um pensamento crítico sobre o contexto social que está em sua volta.

A escola precisa ser um lugar acolhedor e inclusivo, de forma a promover relações de convivências nas quais os alunos se sintam comprometidos e valorizados.

\section{DUETO AFETIVIDADE E AUTOESTIMA: CAMINHO PARA A APRENDIZAGEM}

O filme, além de discutir a importância do diálogo na relação professor e aluno, atenta também para a maneira como o fator afetividade pode influenciar positivamente na autoestima dos discentes e na melhora da aprendizagem. Assim, caberá ao educador em plena função, pôr em prática a sua ação de trabalhar a afetividade, pois a interação professor-aluno precisa ser realizada através do afeto, levando o aluno a uma aprendizagem significativa (ALVES, 2011).

De acordo com Santos (2009), o desenvolvimento intelectual e emocional do educando são estabelecidos através dos vínculos entre docente e discente. Portanto, o professor precisa manter vínculos de amor e carinho pelos seus alunos, pois o espaço acadêmico também é um lugar para as trocas de afeto.

Em semelhança com o filme, no cotidiano da sala de aula, os professores também enfrentam grandes desafios de trabalhar com alunos indisciplinados. Para lidar com essa situação, o maior desafio do professor é pensar em diminuir o modelo único de aprendizagem, por isso precisa utilizar vários métodos de ensino para tornar sua aula interessante, perante a qual os alunos interajam, participem, dialoguem e troquem ideias, na obtenção de um melhor aproveitamento na aprendizagem (OLIVEIRA, 2008).

Nesse sentido, o autor destaca a importância de o professor ter iniciativa, pois o jeito de agir do docente em sua sala de aula colabora na participação dos alunos na realização das atividades. 
A aprendizagem e o ensino não podem ser vistos como simples transmissão de conhecimentos, cujo papel do docente restringe-se a ensinar e do discente a aprender, mas sim como uma troca de experiências e conhecimentos, cabendo ao educador ser de fato, o mediador nesse processo. Portanto, é crucial que o docente estabeleça um espaço seguro em sua sala de aula, onde a união e o afeto sejam predominantes.

Rose (2009) sustenta que a prática pedagógica docente precisa ser planejada envolvendo afetividade e atesta para a maneira como o fator afetividade pode influenciar positivamente na autoestima dos discentes e na melhora da aprendizagem.

Esta característica é apresentada no filme quando a professora precisou rever sua metodologia para despertar a atenção dos alunos. Sendo assim, o docente conhecedor da realidade da sala de aula, necessita repensar sua prática pedagógica para que suas aulas sejam interessantes, afetivas e principalmente significativas para que os discentes aprendam com empolgação e entusiasmo. 0 professor precisa, no entanto, esquecer o senso comum que atribui todo o insucesso educacional à indisciplina, agressividade, $\mathrm{e}$ à falta de empenho dos alunos, de forma a inovar suas aulas com projetos e sempre buscar uma formação continuada para contribuir na qualidade do ensino e na formação do aluno (SILVA, 2007).

De acordo com Veiga (2003), o aluno se espelha no comportamento do seu professor, porém algumas virtudes podem contribuir nesse processo, como o amor, carinho, afeto, paciência e o companheirismo.

O filme Escritores da Liberdade salienta como é fundamental o papel do docente que, independente de suas limitações, considera importante modificar a vida dos alunos através de sua conduta profissional. Portanto, o ato de ensinar e educar requer afeto, e quando isso for implantado, certamente o aluno aprenderá melhor (LOPES, 2012).

A prática pedagógica precisa ser pautada no afeto entre educador e educando, ajudando o aluno a desenvolver o seu potencial. 0 filme mostra na sua íntegra a história da professora que soube fazer a diferença em sua prática pedagógica, como também os alunos que aprenderam a sentir o gosto pela educação, mesmo em face a tantas adversidades (ALVES, 2011).

O docente que valoriza e trabalha a autoestima dos educandos ajuda no que ele traz dentro de si sem preconceito e humilhação.

Os alunos não vão à escola apenas para aprender e pronto, mas para construir conhecimentos em um sentido de aproximar-se do culturalmente estabelecido, mas também como "motor" do desenvolvimento do seu tempo, de suas capacidades e equilíbrio pessoal, de sua inserção social, de sua autoestima e relações interpessoais (ANTUNES, 2008, p. 22).

A autoestima vai sendo construída através da interação com o meio e os professores têm um grande comprometimento com essa tarefa. Nas cenas do filme Escritores da Liberdade, primeiramente a professora Erin Gruwell conseguiu elevar a autoestima dos alunos, fazendo com que eles, motivados para a aprendizagem, valorizassem a si mesmos.

A educação exige professores que estimulem os seus alunos a serem críticos, criativos e reflexivos, frente a esta sociedade excludente. Portanto, a educação precisa fazer a diferença no intuito de encaminhar os seus alunos ao pleno exercício da cidadania para conquistarem sua autonomia (SILVA, 2007).

Segundo Lembo (2001), o docente inovador contribui na maneira correta de transmissão de conhecimentos proporcionando condições apropriadas de ensino de maneira a contribuir para uma mudança significativa na política escolar. 0 professor precisa estar consciente de que precisa estar sempre em busca de uma preparação profissional contínua.

Diante da realidade do filme é importante que os profissionais da educação concretizem essa prática pedagógica, pois está relacionada à nossa atual realidade, diante da qual os docentes sofrem com a violência e a desigualdade. No entanto, o educador precisa conhecer a realidade do aluno para poder intervir e ajudá-lo na aprendizagem de forma mais abrangente e significante.

Nesse sentido Carvalho (2001) evidencia que:

Um dos resultados significativos provenientes das pesquisas em formação de professores é o que indica um dos obstáculos para o professor adotar uma atividade docente inovadora e criativa, além [...] e falha no mínimo de conteúdo, são suas ideias, sobre ensino e aprendizagem, "as ideias do senso comum" (CARVALHO, 2001, p.111). 
Segundo Alves (2011), a escola tem que rever sua função na aplicação da sua prática pedagógica com postura ética, almejando seu papel de transformadora e conscientizando o professor para as metodologias em constantes mudanças.

Para Lopes (2012), cabe ao educador o desafio de mudar sua prática pedagógica no intuito de garantir a participação de todos os alunos nas atividades, sem discriminação, pois todos têm capacidade para apropriar-se do conhecimento. Ser educador é como ser arquiteto, podemos construir obras inabaláveis, admiráveis ou obras medíocres que nada representam para o contexto onde estão inseridos.

A formação do profissional da educação está relacionada ao indivíduo com grandes capacidades de conduzir a teoria e a prática, preparando o aluno para a sua convivência harmônica em sociedade. 0 filme deve ser visto com apreço pela sua ênfase no papel da educação como mecanismo de transformações individuais e comunitárias.

\section{CONSIDERAÇÕES FINAIS}

Através da narrativa do filme biográfico Escritores da Liberdade, este artigo analisou a construção de uma prática pedagógica pautada na perspectiva do filme, envolvendo a interação professor-aluno, bem como a importância do diálogo e do afeto no ensino.

A obra cinematográfica apresenta cenas emocionantes e comove o público, abordando com maestria como as questões sociais, humanas e culturais estão interligadas às questões educacionais. Demonstra de forma exemplar que, mesmo diante de uma sala de aula com alunos indisciplinados, desinteressados e agressivos, o professor tem muito a fazer pela autoestima e aprendizagem de seus educandos. Caberá ao docente uma autoavaliação da forma como está conduzindo o seu trabalho, de modo a promover mudanças necessárias e renovar a sua metodologia, considerando a realidade dos seus alunos e o contexto em que se encontram inseridos. A prática pedagógica da professora está relacionada a um ensino sóciohistórico/cultural, no qual o filme analisado apresenta, dentro de sua perspectiva, como a interação pedagógica pode aprimorar vínculos afetivos e promover valores, favorecendo de forma positiva a busca do conhecimento.

A metodologia utilizada está relacionada com os interesses dos discentes, pois a docente é a mediadora do conhecimento, auxiliando a troca de conhecimento entre o aluno e o meio em que está inserido diante do qual, alunos e professores cooperam em prol de projetos comuns.

É importante que o professor reflita sobre o meio onde estamos inseridos, num mundo de diversidade no qual a individualidade precisa ser respeitada. Por isso o educador precisa reconhecer seu papel de mediador da aprendizagem, tendo ciência de que todos têm suas limitações para aprender, de forma que favoreça um ensino sem preconceitos.

De acordo com essa perspectiva pedagógica que o filme demonstrou, recomenda-se aos professores, principalmente àqueles que trabalham com os adolescentes em sua sala de aula e que convivem com situações semelhantes às do filme, que é importante rever e aprimorar a metodologia de ensino, fazendo o uso de práticas pedagógicas condizentes à realidade do aluno para despertá-lo e motivá-lo, contribuindo dessa forma para um ensino de qualidade.

Através dessa obra, torna-se necessário que todos os envolvidos com a educação ponderem criticamente acerca dos fatores que geram a violência e a indisciplina no espaço acadêmico, com a finalidade de contribuir na melhoria da relação professor-aluno efetuada de forma dialógica, como também questionar se a escola está de fato concretizando o seu papel de formadora de sujeitos capazes de realizar com sucesso a sua inserção social e mudar a realidade em que estão inseridos, pois somente a tolerância e a aceitação não bastam para a concretização de uma formação educacional emancipadora.

É sem dúvida, um filme com uma mensagem de esperança, cuja intenção não foi apenas de revelar situações de violência em que crianças e adolescentes estão envolvidos, mas também, de estimular ações de mudança.

\section{REFERÊNCIAS}

[1] Alves, N. Formação de professores: pensar e fazer. 8. ed. São Paulo: Cortez, 2011.

[2] Antunes, C. Reflexões sobre a aula e práticas pedagógicas diversas. 2. ed. Petrópolis, RJ: Vozes, 2008. 
[3] Ausubel, D. P. A aprendizagem significativa: a teoria de David Ausubel. São Paulo: Moraes, 1982.

[4] Baron, M. P.; Dorocinski, S. I.; Finck, N. T. L.; Kriegl, M. L.; Pelizzari, A. Teoria da Aprendizagem Significativa Segundo Ausubel. Revista PEC, Curitiba, v.2, n.1, p.37-42, jul. 2001-jul. 2002. Disponível em: <http//portaldoprofessor.mec.gov.br/storage/materiais/0000012381.pdf>. Acesso em: 18 jun. 2015.

[5] Carvalho, A. M. P. de; Castro, A.D. de; Pérez, D. G. Ensinar a ensinar: didática para a escola fundamental e média. São Paulo: Cengage Learning Editores, 2001.

[6] Cordeiro, J. Didática.1.ed., São Paulo: Contexto, 2007.

[7] Freire, P. Pedagogia da Autonomia. 35 ed., São Paulo: Paz e Terra, 1996.

[8] Freire, P. Pedagogia do Oprimido. 17.ed., Rio de Janeiro: Paz e Terra, 1996a.

[9] Garcia, J. Indisciplina na escola: uma reflexão sobre a dimensão preventiva. Revista Paranaense de Desenvolvimento. Curitiba, n. 95, p. 101-108, jan./abr. 2006.

[10] Hillal, J. Relação Professor Aluno: Formação do homem consciente. 2.ed., São Paulo: Paulinas, 1995.

[11] Lembo, J. M. Por que falham os professores. São Paulo: EDUSP, 2001.

[12] Libâneo, J. C. Democratização na escola pública: a pedagogia crítico-social dos conteúdos.3.ed., São Paulo: Loyola, 1999.

[13] Libâneo, J. C. Didática. São Paulo: Cortez, 1999a.

[14] Lopes, A. O. Relações de Interdependência entre Ensino e Aprendizagem. Didática: o ensino e suas relações. 13.ed. Campinas: Papirus, 2012.

[15] Moreira, M. A. Aprendizagem Significativa: teoria de David Ausubel. 2 ed. São Paulo: Centauro, 2006.

[16] Oliveira, M.K. Vygotsky: aprendizado e desenvolvimento: um processo sócio-histórico. São Paulo: Scipione, 2008.

[17] Rego, J. G. A educação obrigatória: seu sentido dedutivo e social. Porto Alegre: Vozes, 2001.

[18] Rose T. M. S. Acompanhamentos de Pré-escolares Agressivos: adaptação na Escola e Relação ProfessorAluno. Psicologia Ciência e Profissão, São Carlos, v. 29 n. 1, p. 132-145, 2009. Disponível em: <http://www.scielo.br/pdf/pcp/v29n1/v29n1a11>. Acesso em: 10 jul. 2015.

[19] Santos, S.C. O processo de ensino-aprendizagem e a relação professor-aluno: aplicação dos "Sete princípios para a boa prática na educação de ensino superior". Cadernos de Pesquisas em Administração, São Paulo, v. 08, n.1, jan./mar. 2009. Disponível em: <http://www.ead.fea.usp.br/Cad-pesq/arquivos/v08-1art07.pdf>. Acesso em: 8 jul. 2015.

[20] Silva, P. S. A relação aluno-professor no processo de ensino aprendizagem. Revista Espaço da Sophia. n.7, out. 2007. Disponível em: <http://www.educacao.salvador.ba.gov.br/site/documentos/espaco-virtual/espaco-praxispedagogicas/RELA\%C3\%87\%C3\%830\%20professoraluno/a\%20relacao\%20professor\%20aluno\%20no\%20process o\%20ensino\%20aprendizagem.pdf>. Acesso em 15 jul. 2015.

[21] Veiga, I. P. A. Didática: o ensino e suas relações.7. ed., Campinas: Papirus, 2003. 


\section{Capítulo 15}

\section{Do ensino tradicional à abordagem humanista: Uma análise do filme sociedade dos poetas mortos}

\section{Demóstenes Dantas Vieira \\ Efraim de Alcântara Matos \\ Pedro Felipe de Lima Henrique \\ Josenildo Pinheiro da Silva}

Resumo: Este trabalho visa analisar a obra fílmica Sociedade dos Poetas Mortos (2004), levando em consideração o confronto entre a educação tradicional/tecnicista e o modelo de educação centrada no sujeito. Com relação à fonte teórica, vale ressaltar as considerações dos estudos de Rogers (1987), Freire (1979), Gadotti (2003), Ausbel (1963), Anastasiou (2002), Demo (2004), dentre outros que, aqui, julgamos essenciais à essa discussão. A partir da análise fílmica, propomos perceber como o papel do educador e da Abordagem Humanista é fundamental para o despertar das subjetividades, da criticidade e sensibilidade dos educandos, características indispensáveis à formação totalitária de indivíduos capazes de decidirem quanto aos rumos de suas vidas, agindo conforme os princípios da autonomia e de sua consciência.

Palavras-chave: Análise fílmica; Abordagem Humanista; Autonomia. 


\section{PARA INÍCIO DE CONVERSA}

O filme Sociedade dos Poetas Mortos (1989) apresenta-se como exemplar de obras cinematográficas de cunho pedagógico em evidencia pós-teorias humanistas e interacionistas. Podemos inferir que o mesmo representa a crítica ao ensino tradicional que predominou no processo de ensino-aprendizagem desde a origem da instituição escolar até meados do século XX com o desenvolvimento e propagação da psicologia humanista e teorias interacionistas, seja o cognitivismo piagetiano ou o sociointeracionismo de Lev Vygotsky. A obra em análise traz à baila a importância da Abordagem Humanista representada principalmente por Maslov, Carl Rogers e Paulo Freire.

A princípio, salientamos a riqueza da mimese na transposição/transcriação das realidades sociais que apresenta um período de ruptura com a educação centrada no professor e no conteúdo para uma educação centrada no sujeito. À vista disso, propomos a análise da obra partindo principalmente da teoria humanista que preza por processos educativos centrados na pessoa.

Influenciada pela fenomenologia existencial, o humanismo apresenta-se como uma reação a práticas psicológicas e pedagógicas centradas no comportamentalismo behaviorista e no ensino tradicional. Nesse sentido, este trabalho nos remonta a uma reflexão sobre a participação do humanismo no processo de ruptura com a educação tecnicista/tradicional e behaviorista, trazendo à tona o princípio existencialista do ser humano como ponto de partida da reflexão e o princípio fenomenológico da consciência humana do mundo que o cerca, dos fenômenos e dos processos de subjetivação (MACHADO, 2015).

Em vista disso, este trabalho propõe uma discussão sobre educação e condição humana, o que nos remete a uma reflexão sobre o processo de formação de subjetividades inerentes à prática educativa. Para tanto, adotamos o filme como um documento histórico pensando a relação da arte com a vida social. Como métodos procedimentais, adotamos a análise fílmica e método bibliográfico, cujo aporte teórico compreende os estudos de Rogers (1987), Freire (1979), Gadotti (2003), Anastasiou (2002), Demo (2004). Propomos, portanto, compreender o filme supracitado levando em consideração o papel do professor no processo de construção de subjetividades, na "erupção" do sujeito sócio, histórico, político afetivo, e, acima de tudo, humano, como indivíduos capazes de se fazerem senhores de sua própria existência.

\section{A ESCOLA E AS TEORIAS DA APRENDIZAGEM}

A existência da escola cumpre um objetivo antropológico muito importante, desde a socialização do conhecimento cientifico e cultural para as novas gerações até a inserção efetiva dos educandos na sociedade. 0 educador precisa estar atento aos processos de construção da aprendizagem, de modo que se possa combater o ensino centrado apenas na reprodução de conteúdo, focando na formação total do homem, não só no desenvolvimento cognitivo, mas também social, físico, afetivo, psíquico, emocional etc.

Desde o início da instituição escolar, o ensino técnico foi privilegiado; para tal, o discurso positivista vigente foi transferido à instituição escolar, de modo que esta tornou-se, de certa forma, repetidora dos ideais sociocapitalistas. É perceptível no sistema educacional de ensino tradicional: a formação técnicoindustrial, a formação administrativa hierárquica e impositiva, a avaliação quantitativa, o relacionamento impessoal professor-aluno, a competitividade, a exaltação dos "melhores" alunos, até mesmo na formação das carteiras em sala de aula, que se impõem enquanto ordem necessária a uma boa aula. Tais princípios, de modo geral, predominaram por mais de um século e ainda encontram espaço nas estruturas socioeducacionais. O filme Sociedade dos Poetas Mortos nos mostra o quanto esse tipo de ensino é desconcertante e desinteressante, visto que suprime os desejos, valores, objetivos e necessidade individuais dos alunos.

Com relação aos fatores que proporcionam a construção do conhecimento, destacam-se as seguintes teorias: o behaviorismo (centrado nas relações psicológicas de estímulo-resposta-recompensa); o cognitivismo (centrado no desenvolvimento das estruturas mentais); a teoria histórico-cultural (centrada na interação); a teoria da percepção (baseada na Gestalt); a teoria das inteligências múltiplas (baseada na premissa de que existem diversos tipos de inteligências, cujas capacidades podem ser adquiridas), entre outras. Inspirados nessas teorias, muitos trabalhos científicos e até mesmo artísticos, como é o caso da obra em análise, desenvolveram inúmeros trabalhos que nos proporcionaram contundentes reflexões sobre o papel do educador em sala de aula.

Nesse sentido, a obra analisada nos faz refletir sobre a necessidade de significação à educação, que numa perspectiva não-dialógica, técnico-profissional e cientificista suplanta as características sensíveis, frutos do processo de humanização fundamental à inserção do indivíduo na sociedade, não só enquanto 
profissional, mas como ser humano pensante, sensível etc., e cujos valores sobrepõe-se aos ideais de produção capitalista. Nesse sentido, podemos inferir que o professor-educador, personagem do filme, proporciona uma mensagem bastante significativa à educação e ao professor-educador da contemporaneidade. Mensagem esta que denominamos de "erupção do outro", que facilmente poderia ser chamada de "erupção do ser".Compreender o processo de ensino-aprendizagem no filme Sociedade dos Poetas Mortos e as críticas ao ensino tradicional exige antes de tudo entender como este processo ocorre interna e externamente, numa perspectiva não só orgânica como também psicossocial.

Piaget (1977) descreve em seus estudos que o desenvolvimento humano acontece mediante a formação de estruturas mentais que se sucedem. 0 mesmo atribui ao desenvolvimento humano um carácter psicobiológico, visto que, segundo ele, a aprendizagem que se daria num contexto social só poderia acontecer mediante a formação das estruturas mentais. Apesar de o processo de "imitação" na formação cognitiva desenvolver-se no social, parece-nos que Piaget privilegiou as capacidades psíquicas e, por sua vez, também genéticas de determinadas fases de desenvolvimento. Piaget propõe que a aprendizagem pode alcançar um nível de maturação cognitiva.

Enquanto Piaget (1977) desenvolve uma teoria geral sobre a aprendizagem humana, Vygotsky (1991/1997) elabora um estudo mais próximo específico sobre as condições da aprendizagem escolar. De certa forma podemos inferir que este realiza um estudo que complementa aquele. Vygotsky (1991/1997) não anula o entendimento sobre a formação das estruturas mentais, entretanto o mesmo ressalta que elas sozinhas não garantem a efetivação da aprendizagem. De acordo com ele, o fator determinante da aprendizagem é o meio social e, por sua vez, a interação. A obra fílmica analisada mantém um diálogo com a teoria de Vygotsky, principalmente quando recria um processo de ensino-aprendizagem baseado nas relações com o meio e com o outro. E quando nos referimos ao outro, falamos também do educador, não só nas relações de mediação como também nas relações de "erupção" do indivíduo enquanto ser humano, individual e social. Indivíduo repleto de necessidades, desejos, sonhos e voz, que não podem ser sufocados por normas centradas numa educação comportamentalista, de certa forma, nos moldes da educação sociocapitalista.

Já a Teoria da Aprendizagem Significativa, de Ausbel (1963), pode ser entendida como elemento continuador das teorias interacionistas/construtivistas, conforme escreve Moreira, Cabalheiro e Rodriguez (1997, p. 19) "o conceito de aprendizagem significativa, hoje tão utilizado no contexto educativo, embora proposto, inicialmente, por Ausubel $(1963,1968)$ é compatível com outras teorias construtivistas contemporâneas", entenderemos o porquê nas linhas que seguem.

De acordo com Ausbel (1963) a aprendizagem só tem sentido quando o sujeito consegue atribuí-la um significado. Conforme escreve Ausubel (1963), a aprendizagem é o mecanismo humano através do qual as informações são processadas pelo indivíduo de forma não-arbitrária e substantiva. 0 conhecimento tornase não-arbitrário quando o educando consegue apropriar-se de novos saberes com os conhecimentos já adquiridos em sua formação. Segundo esse princípio, as novas informações não se relacionam com todos os aspectos da estrutura cognitiva, mas apenas com os conhecimentos relevantes para o sujeito, onde o conhecimento prévio pode ser compreendido como matriz cognitiva através da qual incorpora-se novos saberes. Nesse sentido, a incorporação cognitiva apresenta-se como possibilidade de se aprimorar os conhecimentos adquiridos através das experienciação.

Certos disso, vale refletir sobre os processos que se estabelecem dentro e fora dos relacionamentos escolares, assim como compreender a relação dos mesmos com a efetivação dos educandos como indivíduos que se fazem e se reconhecem enquanto seres sócio-histórico-culturais, como sujeitos detentores de conhecimento. Seguindo o pensamento de Ausbel (1963) a aprendizagem será significativa quando for substantiva, ou seja, quando entendermos que as estruturas cognitivas assimilam apenas a substância do novo conhecimento, sua essência e não as regras, palavras e leis que regem os conteúdos curriculares. Nesse sentido, a aprendizagem significativa deve ser entendida como "um conceito subjacente a subsunçores, esquemas de assimilação, internalização de instrumentos e signos, construtos pessoais e modelos mentais, significados compartilhados e integração construtiva de pensamentos, sentimentos e ações" (MOREIRA, CABALHEIRO E RODRIGUEZ, 1997, p. 01). 0 que nos remete diretamente "aos construtos dos demais autores e à internalização de instrumentos e signos de Vygotsky" (MOREIRA, CABALHEIRO E RODRIGUEZ, 1997, p. 20).

Abordagem Humanista, por sua vez, traz à baila o sujeito como construtor do conhecimento. Acredita no educando como ser epistêmico na totalidade da condição humana, não apenas o lado cognitivo. Ela retoma uma discussão já tratada por outrem o papel das emoções, os vínculos afetivos, à aprendizagem com significado, etc. A sua grande contribuição é o entendimento da educação como uma "busca realizada 
por um sujeito que é o homem", sendo ele mesmo "sujeito da sua própria educação" (FREIRE, 1979, p. 28). Nesse sentido, o indivíduo possui dentro de si diversos mecanismos para autocompreensão e para modificação de seus próprios conceitos, atitudes e comportamentos. Tais mecanismos serão ativados se proporcionados o clima (passível de subjetivação) e procedimentos psicológicos facilitadores (ROGERS, 1989).

Conforme escreve Rogers (1989, p. 73) "as experiências de vida, o clima psicológico da sala de aula, a integração professor/aluno são fatores importantes para a aprendizagem”, destacando a autonomia do indivíduo educando. Pensando essa questão, Rogers (1989) elenca algumas condições necessárias para a efetivação da educação centrada no sujeito: a necessidade de liderança ou de facilitadores; a motivação; a busca por autonomia do indivíduo; a responsabilização pelo processo de aprendizagem; o clima psicológico facilitador da aprendizagem, entre outros. Discutiremos cada um deles no tópico a seguir, onde apresentaremos a discussão dos dados da nossa pesquisa.

\section{A ABORDAGEM HUMANISTA E OS POETAS MORTOS}

O filme Sociedade dos Poetas Mortos (Dead Poets Society - título original) é uma produção de 1989, direção de Peter Weir ${ }^{21}$. A narrativa fílmica se passa em 1959, na Welton Academy, tradicional escola preparatória dos Estados Unidos. Nesse ano, o Sr. Keating, ex-aluno da escola (interpretado por Robin Williams) retorna à instituição como professor de literatura, entretanto os seus métodos logo tornam-se inconvenientes por não se situarem no contexto tradicional-tecnicista da instituição. De certa forma, o filme traz à tona o contexto das transformações socioeducacionais advindas da abordagem humanista surgida na década de 1950 e que se tornou bastante significativa nas décadas de 1960 e 1970.

Em vista disso, propomos analisar o papel do professor John Keating na obra levando em consideração como a construção do personagem perpassa o entendimento do professor a partir da Abordagem Humanista. Para tanto, partiremos de quatro categorias citadas por Roger (1989): a necessidade de liderança; a motivação; a busca por autonomia do indivíduo; a responsabilização pelo processo de aprendizagem; o clima psicológico facilitador da aprendizagem.

Focado nas necessidades de superação da timidez e da ausência de interação entre os alunos, o professor Keating dispõe-se a romper as barreiras que se formaram no percorrer de sua trajetória na instituição na qual leciona. Essas se apresentam não só nos educandos (em superar sua timidez e relacionar-se com o outro), mas, e, principalmente, nos paradigmas estabelecidos no processo de ensino tradicional até então vigentes. 0 professor permanece íntegro e instransponível, mesmo quando sua metodologia não é bemquista pelos demais professores e funcionários.

Mudar é necessário, entretanto as mudanças exigem idealizadores, sonhadores e, acima de tudo, pessoas dispostas a tentar lutar por um objetivo muitas vezes tido como utópico. Uma das cenas mais importantes do filme é aquela em que o professor solicita que os alunos rasguem a página do livro em que há uma tradicional explicação sobre o que é uma poesia, dando instruções sobre métrica, rima, estrutura e uma "receita" de como o poema deve ser analisado. A princípio, o professor causa certo estranhamento nos alunos, entretanto um a um começa a fazer conforme orientado pelo docente:

${ }^{21}$ Peter Weir é diretor de cinema e renomado roteirista australiano, com formação Arte e Direito pela Universidade de Sydney. Vem colecionando diversos prêmios importantes na área do cinema, tendo conquistado o Globo de Ouro quatro vezes na categoria Melhor Diretor com as seguintes produções: A testemunha, Sociedade dos Poetas Mortos, $O$ show de Truman - $O$ show da vida e Mestre dos mares. Tendo conquistado também o maior prêmio do cinema francês, César, na categoria Melhor filme estrangeiro com a produção de Sociedade dos Poetas Mortos. É considerado um dos maiores nomes do cinema contemporâneo. 


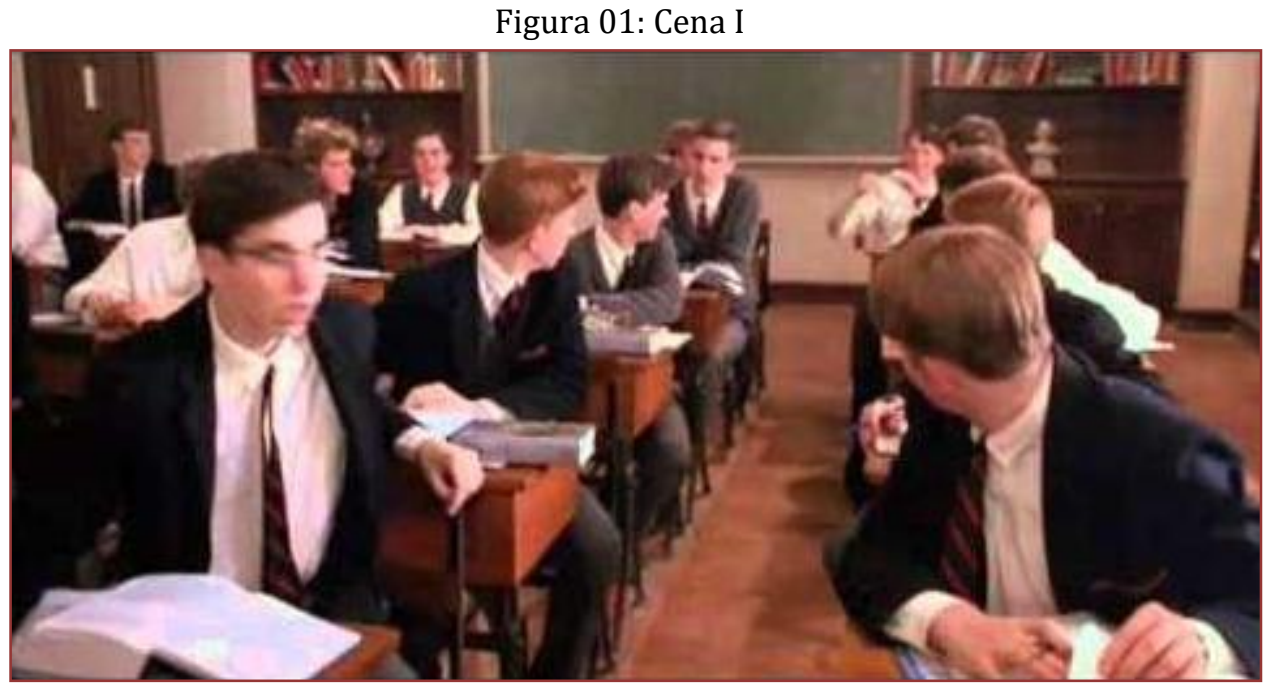

Fonte: Sociedade dos Poetas Mortos (1987)

A cena nos mostra o quanto o Ensino Tradicional/Tecnicista oprime o indivíduo, fazendo da própria arte um manual de normas e regras. Esse primeiro contato com os alunos foi de grande importância, pois o docente os instiga a romper com os paradigmas existentes que tendem a modular o processo de ensino aprendizagem, restringindo-o à regras, normas e tratamento positivista que predominou (e ainda predomina) na instituição escolar e mesmo no tratamento dado à arte e às Ciências Humanas no contexto educacional. 0 professor traz à tona um ensinamento muito importante de que devemos "aprender a apreciar as palavras e a linguagem", trazendo uma discussão sobre a própria condição humana. Segundo o Sr. Keating, "não lemos e escrevemos poesia porque é bonito. Nós lemos e escrevemos poesia porque pertencemos a raça humana. E a raça humana está cheia de paixão. Medicina, lei, negócios e engenharia são ocupações nobres para manter a vida. Mas poesia, beleza, romance e amor... São razões para ficar vivo". (SOCIEDADE DO POETAS MORTOS, 1987).

A prática pedagógica do professor nos remete à necessidade de liderança, de facilitadores. 0 processo de constituição do sujeito perpassa o papel docente de facilitador. 0 que o professor propôs foi ir além do mecanicismo, da técnica, e mergulhar na própria condição metafísica do homem. Nesse sentido, coube a ele liderar os garotos para despertar o interesse pela disciplina, estimulando a reflexão sobre o próprio sistema e sobre as amarras que nos prendem a um forte positivismo da vida, em que não paramos para refletir sobre o que está além da matéria, sobre a arte, as emoções, a paixão. Conforme escreve Cassirer (2004), o homem constitui-se como homem pelos saberes que produz, magia, linguagem, mito, religião, ciência, cultura e arte. Sem esses saberes, não seríamos diferentes dos demais animais. Segundo Rogers (1989, p. 78) "o lider é uma figura de autoridade numa dada situação", um "facilitador" que é essencial para o despertar da autonomia do sujeito. Cabe a ele promover o clima necessário ao autoconhecimento e ao desenvolvimento das potencialidades dos educandos.

Outro aspecto importante trazido por Rogers $(1987$, p. 78$)$ é a responsabilização do aluno pelo processo de aprendizagem. Segundo ele, "a pessoa facilitadora compartilha com os outros alunos [...] a responsabilidade pelo processo de aprendizagem". Nesse sentido, rompe-se com o paradigma reprodutivista em que as aulas são centradas no professor e na reprodução de conteúdos. Abre-se espaço ao aprender compartilhado, ao aprender fazendo. Sobre essa questão, gostaríamos de destacar dois momentos, retratados nas imagens a seguir: 


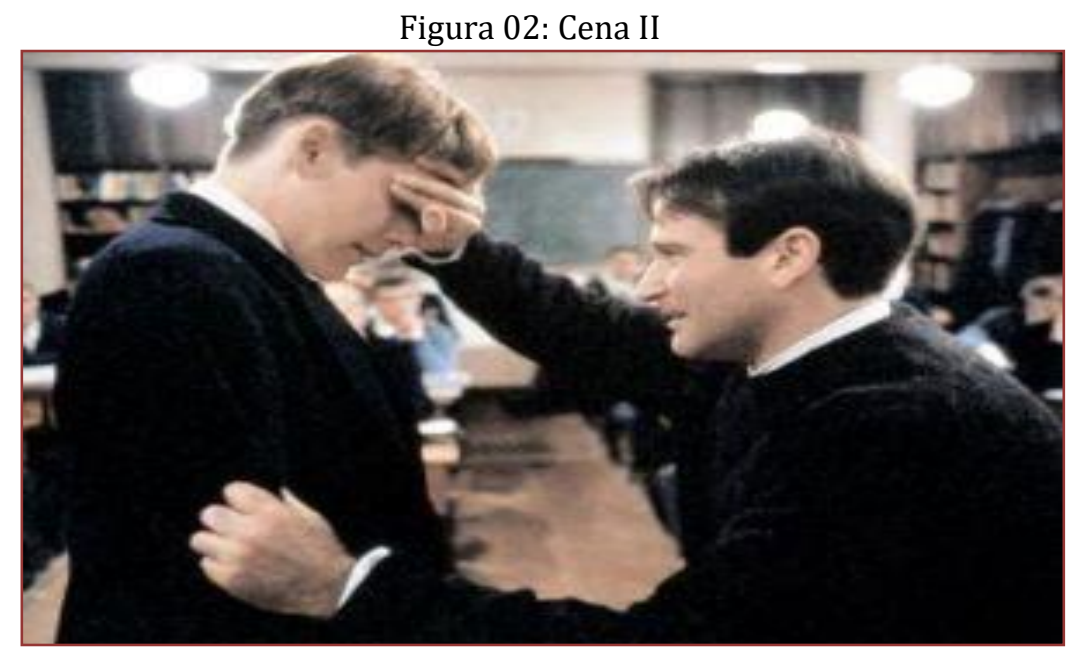

Fonte: Sociedade dos Poetas Mortos (1987)

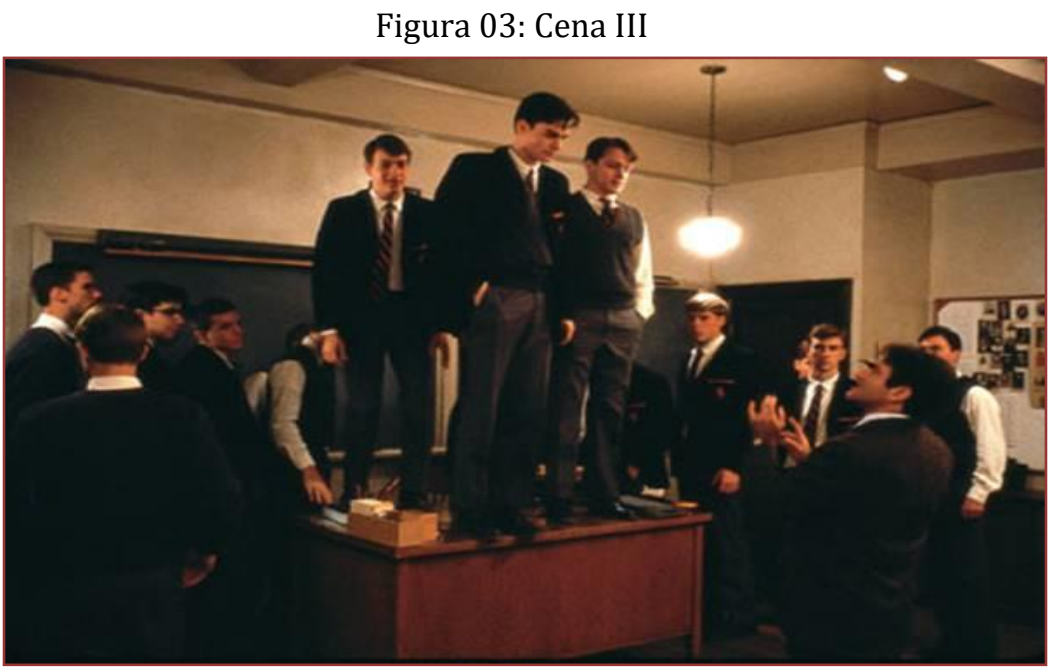

Fonte: Sociedade dos Poetas Mortos (1987)

A primeira materialidade citada é um caso peculiar em que o professor incentiva a imaginação e a criatividade de um aluno tímido. Nessa aula, o Sr. Keating propõe que os alunos exponham oralmente as produções escritas (poesias) solicitadas na aula anterior. A personagem Todd Anderson, aluno bastante tímido, não havia realizado a atividade. Então o professor convidou-o a realizar descrições das imagens do seu pensamento.

Antes disso, o professor elabora um pequeno discurso sobre o aluno reiterando o seu valor. De olhos fechados, Tod Anderson começa a descrever as imagens do seu pensamento, demonstrando que dentro de cada um de nós existe a poesia, criatividade, beleza e emoção, sendo necessário deixar fluir as nossas competências linguísticas e estéticas, pois fazem parte da natureza humana. Tod Anderson conclui a atividade produzindo, vivenciando, deixando fluir a arte que nos perpassa. Isso nos remonta à responsabilização do aluno pela própria aprendizagem e à necessidade de motivação que, segundo Rogers (1989), é fundamental para a construção da autonomia dos educandos. Segundo Rogers (1989, p. 78), é necessário que o professor/facilitador proporcione a partir de si mesmo, de suas experiências, de recursos didáticos, dentre outros, o estímulo necessário ao processo de ensino aprendizagem, assumindo para si o papel de "erotizador" do saber, conforme escreve Rubem Alves (2008).

É interessante lembrar que a responsabilização da aprendizagem perpassa o autoconhecimento e a motivação, pois os alunos só assumiram esse papel se tornarem conhecimentos de suas competências e habilidades, para assim assumirem a postura de construtores da própria aprendizagem. Para tanto, relatamos a importância de se aprender fazendo, pois só assim o aluno sentirá que faz parte do processo. Segundo a Unesco, no que se refere aos quatro pilares da educação para o século XXI, é necessário aprender a conhecer, a conviver, a ser e a fazer. E isso só se torna possível se houver motivação. 
A segunda materialidade citada nos remonta a necessidade de inclusão do indivíduo no processo. Ao solicitar que os alunos subissem em cima das mesas, o professor estava, a princípio, desenvolvendo uma metáfora sobre a necessidade de vermos as coisas de cima, sobre outros ângulos. Isso denota a importância de inserir o aluno no desenvolvimento das aulas. Não se concebe mais a organização de salas em que o professor é o detentor do saber e da voz, enquanto os alunos são depósitos de informação. É necessário que o aluno faça, que ele experimente. É preciso que haja interação e participação para que haja responsabilização.

Em parte, a Abordagem Humanista apresenta-se como uma utopia, se levarmos em consideração o sistema educacional vigente, em especial, o brasileiro. Entretanto, é uma utopia necessária sem a qual os objetivos de formação humana total não podem se realizar. Gadotti (2003) afirma que não se pode deixar de crer na educação, "a boniteza de um sonho". Demo (2004) enfatiza que a utopia é indispensável ao educador, pois é ela que nos dá forças para lutar pelas mudanças necessárias. Acreditar nas mudanças é fundamental para que as mesmas se concretizem, embora seja evidente que

quando o professor é desafiado a atuar numa nova visão em relação ao processo de ensino e aprendizagem, poderá encontrar dificuldades, até mesmo pessoais, de se colocar numa diferenciada ação docente. Geralmente, essa dificuldade se inicia pela própria ruptura com o repasse tradicional (ANASTASIOU, 2003, p. 71).

Conjecturar-se em uma prática distinta é compreender-se diferente do outro. Numa perspectiva históricosocial é ser excluído. Nesse sentido, o educador necessita estar consciente das barreiras que enfrentará caso deseje lutar pela "utopia" humanista à qual, aqui, nos referimos. A necessidade de mudarmos a ordem, de trocarmos a tradição pela espontaneidade, o individual pelo coletivo, o técnico pelo pessoal, a quantitatividade pela qualidade, o silêncio pelo dialogismo. Santos (apud ANASTASIOU, 2003, p. 72) enfatiza as seguintes mudanças:

No lugar do mecanicismo, a interpenetração, a espontaneidade e a autoorganização; no lugar do determinismo a imprevisibilidade; No lugar da reversibilidade, a irreversibilidade e a evolução; no lugar da ordem a desordem; no lugar da necessidade, a criatividade e o acidente, e, portanto, no lugar da eternidade, a história construída com a ação dos seres humanos, num tempo e num espaço histórico. 0 complexo é o que é tecido junto.

Nesse sentido, o educador torna-se mola mestra no despertar das individualidades, ou seja, no "desvendar" dos sonhos, da criticidade, do inserir-se socialmente orientado pelos seus objetivos enquanto seres humanos e profissionais. Para tal, é indispensável a interação com o outro, e, por sua vez, o diálogo. Vale ainda salientar que o educador necessita romper, mudar etc. Afinal, o processo de construção do conhecimento não pode ser visto numa perspectiva positivista, objetiva e imutável, mas numa perspectiva dialética, visto que os avanços são obtidos através dos confrontos entre o passado e o presente, o velho e o novo, o concreto e o abstrato.

A erupção do sujeito no filme é bastante clara e contundente. A expressão que facilmente caracterizaria esse fenômeno é a expressão em latim tão utilizada pelo professor: carpe diem. Estimulados pelo educador para viverem o presente, experienciarem as emoções, lutarem pelos seus sonhos, não deixarem a poesia morrer nos corações, os alunos começam a perceber o quanto suas vidas vão além dos mecanicismos e imposições sociais. As personagens se mostram decididas a tornarem-se sujeitos sociohistóricos e culturais e, por conseguinte, senhores de suas vidas. Essa expressão poderia ser compreendida como o despertar das individualidades de cada aluno, despertar este valorizado no discurso do professor e expresso através de algumas indagações feitas por ele aos seus discentes: "O que vocês querem hoje? Para que vocês estão aqui? Quais os seus objetivos?".

O último aspecto que gostaríamos de analisar sobre a Abordagem Humanista no filme é a construção de um clima facilitador em que se torne possível a aprendizagem com o outro, conforme escreve Rogers (1989). Durante o desenrolar da narrativa, um grupo composto por alunos do Sr. Keating e por ele inspirado reinicia uma pequena sociedade cujo objetivo era viver o presente e deleitar-se com a poesia. 


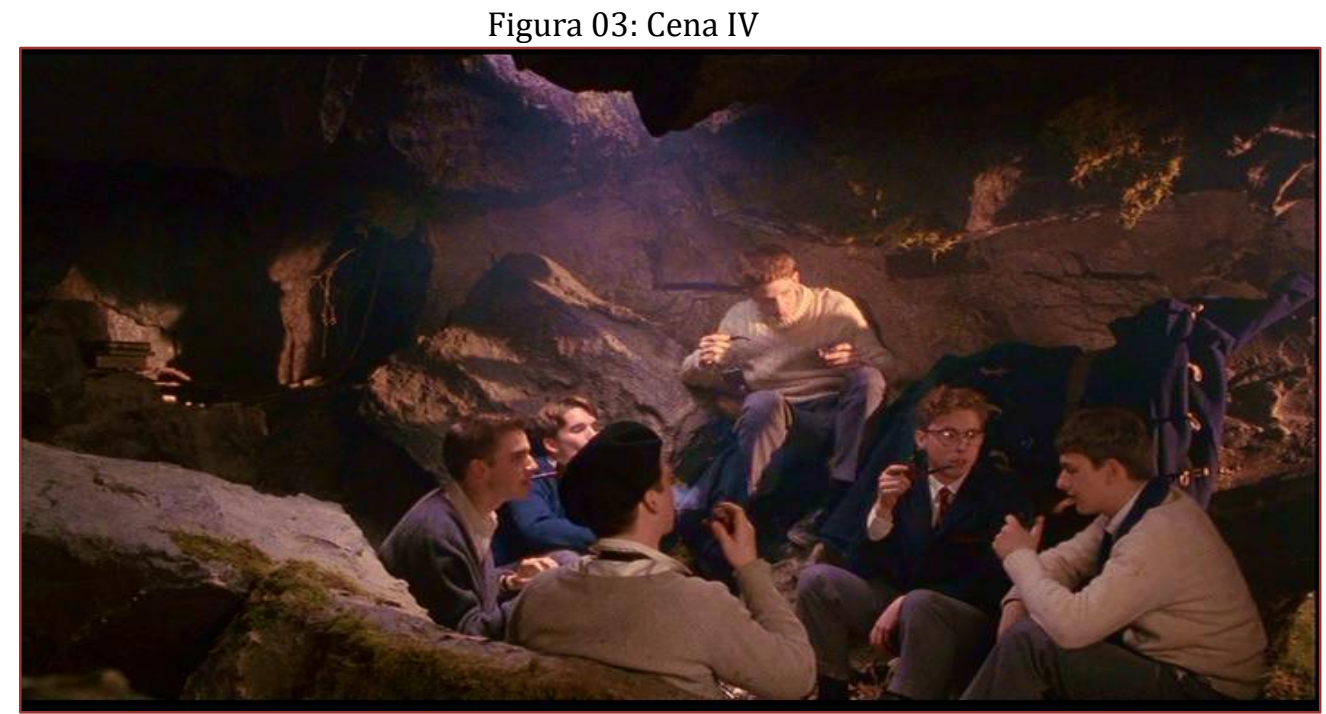

Fonte: Sociedade dos Poetas Mortos (1987)

O nome do grupo dá nome ao filme, Sociedade dos Poetas Mortos, e refere-se à morte da poesia, da sensibilidade, do amor e, por sua vez, da subjetividade. Esse título faz uma alusão à sociedade moderna e industrial, cujos poetas estão "mortos", cuja poesia e beleza já não existem, tudo isso, evidentemente, no sentido metafórico da existência na qual se privilegia o material em detrimento do metafísico. É interessante lembrar que essa "organização" é mais do que um grupo de alunos "baderneiros", como foi compreendido pela instituição. É um grupo formado para se estabelecer a troca de experiências, o compartilhamento de produções poéticas, de aprendizagens. Um grupo de resistência ao sistema tradicional opressor, no qual só há espaço para a técnica e que não deixa ecoar a voz dos principais interessados no processo de ensino-aprendizagem, os educandos.

Podemos ainda inferir que o filme faz uma severa crítica ao ensino tradicional/tecnicista, cujo objetivo era formar apenas profissionais técnicos/especializados. A crítica a esse sistema é bastante clara. Neil, uma das personagens do filme e aluno da instituição Welton Academy, é forçado pelo pai a preparar-se para exercer uma profissão que agradava à sua família e à sociedade capitalista da época. Objetivando a ascensão social do filho, seu pai suprime os desejos do estudante em ser ator e fazer teatro. A imagem abaixo antecede a última cena do personagem no filme. Para cursar teatro, o aluno Neil falsifica a assinatura do pai em um documento que lhe permite atuar em uma peça de teatro em que ele conseguiu o papel principal. Embora o professor tenha-o orientado a dialogar com seu pai sobre suas angústias e sonhos, sobre o quanto o teatro era importante na sua vida, o personagem preferiu continuar ensaiando a peça escondido de seu pai. Ao descobrir, o progenitor culpou o professor Keating por conduzi-lo à desobediência e decidiu tirá-lo da escola, não dando chances para o garoto se explicar.

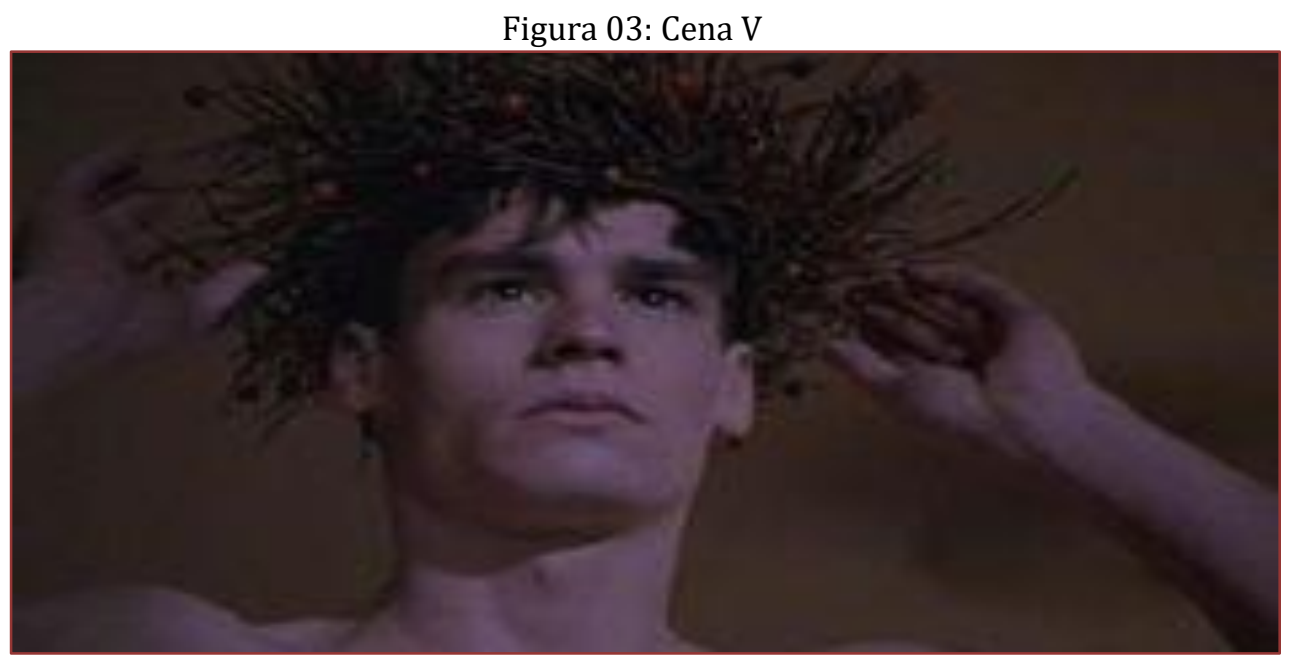

Fonte: Sociedade dos Poetas Mortos (1987) 
O final da obra é trágico. Neil tira toda a roupa do corpo e coloca um adereço da personagem que encenou no palco. Dirige-se ao escritório de seu pai e, com a arma deste, suicida-se. 0 desenrolar da obra nos traz algumas lições importantes. A primeira é que é necessário lutar sempre pelos nossos objetivos e ensinar aos nossos alunos o quão importante é a busca pela realização dos nossos sonhos pessoais e profissionais, o que nem sempre está atrelado ao capital. A segunda lição é que devemos a cada dia estimular os nossos alunos a descobrirem coisas novas, desenvolverem suas habilidades e competências. Enquanto a escola reproduzir a educação bancária, centrada na pedagogia de conteúdo e no tecnicismo industrial, continuaremos formando jovens infelizes, inseguros e incapazes de se inserirem na sociedade e de se realizarem enquanto profissionais.

A educação tradicional/tecnicista não está centrada no sujeito, nem tampouco no aluno. Está centrada na técnica, no conteúdo, no capital. Isso faz da educação uma mera repetidora dos paradigmas materialistas e individualistas da sociedade moderna. 0 despertar da Abordagem Humanista suscita o desenvolvimento do sentimento de responsabilização, a formação de um sujeito coparticipante do processo de ensinoaprendizagem, na relação consigo mesmo, com o outro e com os objetos de aprendizagem. 0 professor enquanto agente mediador do processo deve instigar a "erupção" dos seus educandos, proporcionando um clima facilitador no desenvolvimento de suas individualidades e inteligências e, para tal, apresenta-se o humanismo, enquanto abordagem de compreensão dos educandos enquanto seres humanos totais.

\section{CONSIDERAÇÕES (NÃO) FINAIS}

O objetivo deste trabalho foi analisar o filme Sociedade dos Poetas Mortos (1987) levando em consideração a crítica ao Ensino Tradicional/Tecnicista e construção de uma Abordagem Humanista. A princípio, salientamos as contribuições do filme analisado para compreendermos o processo de mudança dentro da própria instituição escolar e as dificuldades do educador de se colocar frente aos métodos tradicionais arraigados em determinados sistemas e instituições.

A análise aponta para as transformações advindas da concepção humanista e da Aprendizagem Significativa de Ausbel, intimamente relacionadas, assim como das contribuições Interacionismo Sociohistórico de Leon Vygotsky. De certa forma, a construção do enredo apresenta-se como uma reflexão das teorias citadas, embora seja mais evidente a Abordagem Humanista a que nos detemos.

A postura docente do professor Keating aponta para o que Rogers (1989) denominou de precondições para a construção da autonomia dos educandos: a necessidade de um professor líder/facilitador; a responsabilização do aluno pela própria aprendizagem; a necessidade de motivação e o desenvolvimento do clima facilitador da aprendizagem. Esses aspectos (embora existam outros) possibilitam a formação de um indivíduo autônomo capaz de ser coparticipante do processo de ensino-aprendizagem que, na perspectiva humanista, deve estar centrada no sujeito, nas suas competências, inteligências, sonhos, objetivos, angústias e emoções. Nesse sentido, ela se difere do Ensino Tradicional/Tecnicista tanto do ponto de vista teórico como metodológico.

Do ponto de vista teórico, não cabe mais aceitar o ensino centrado no professor, nem no conteúdo, como no Ensino Tradicional/Tecnicista; ele deve estar centrado no sujeito. Do ponto de vista metodológico, não é aceitável a passividade do indivíduo/educando, é necessário a sua interação com o outro, com o conhecimento, com os objetos de aprendizagem. Dessa forma, o discente se sentirá integrado ao processo de aprendizagem, e poderá conduzi-lo de acordo com suas necessidades, desejos e inteligências, de modo que o saber seja deveras significativo.

Por fim, os resultados apontam para a necessidade de repensarmos práticas de ensino centradas no professor, no conteúdo e na técnica, de modo que possamos dar espaço à uma formação humana mais totalitária centrada nas diversas áreas que nos constituem como seres humanos: a ciência, a arte, a metafísica, as emoções e afetos, etc.

Em a Sociedade dos Poetas Mortos (1987), materializam-se as dificuldades enfrentadas pelo docente na tentativa de ruptura com os paradigmas tradicionais, superação das dificuldades de aprendizagem, de interação e socialização dos educandos. Entretanto, o mesmo congrega reflexões que subscrevem à necessidade de uma abordagem mais humanista de ensino, tanto na superação dos problemas de aprendizagem como também no despertar da autonomia dos educandos, indispensável para a sua efetiva inserção no processo de ensino-aprendizagem e, consequentemente, na sociedade, como sujeitos históricos, sociais, políticos e culturais. 


\section{REFERÊNCIAS}

[1] Alves, Rubem. Crônicas: Educação. Curitiba : Nosso Cultura, 2008.

[2] Ausubel, D.P. The psychology of meaningful verbal learning. New York: Grune and Stratton, 1963.

[3] Anastasiou, Lea das Graças Camargo. Processos de ensinagem na universidade: pressupostos para as estratégias de trabalho em aula. Joinville: Univille, 2003

[4] Bock, Ana Mercês Bahia. et al. Psicologias: uma introdução estudo de Psicologia. 13a ed. São Paulo: Ed. Saraiva, 2002.

[5] Cassirer, E. A Filosofia das formas simbólicas - o pensamento mítico. Tradução de Cláudia Cavalcanti. São Paulo: Martins Fontes, 2004.

[6] Demo, Pedro. Sociologia da educação: teoria e método. In: Educação: sociedade e suas oportunidades. Brasília: Ed. Plano, 2004. p. 17-35.

[7] Freire, Paulo. Pedagogia do oprimido. 2. ed. São Paulo: Paz e Terra, 1979.

[8] Gadotti, Moacir, Boniteza de um sonho: ensinar e aprender com sentido. Novo Hamburgo: Feevale, 2003.

[9] Machado, Geraldo Magela (2015). Psicologia Humanista. Disponível em:<http://www.infoescola.com/psicologia/psicologia-humanista/>. Acesso em 10 de Janeiro de 2015.

[10] Moreira, M.A.; Caballero, M.C.; Rodríguez, M.L. (orgs.) (1997). Actas del Encuentro Internacional sobre el Aprendizaje Significativo. Burgos, Espanha. pp. 19-44.

[11] Oliveira, Marta Kohl. Vygostsky e o processo de formação de conceitos. In: LA Taille, Yves de (org.). Piaget Vygostsky, Wallon: teorias psicogenéticas em discussão. São Paulo: Summus, 1992.

[12] Piaget, J. O desenvolvimento do pensamento: equilibração das estruturas cognitivas. Lisboa: Dom Quixote, 1977.

[13] Rego, Teresa Cristina. Vygostsky: uma perspectiva histórico-cultural da educação. 11aㅡ ed. Rio de Janeiro: Ed. Vozes, 1995.

[14] Rogers, Carl. Sobre o Poder Pessoal. São Paulo: Martins Fontes, 3. ed. 1989.

[15] Vygotsky, L. S. A formação social da mente. São Paulo: Martins Fontes, 1991.

[16] ___ Psicologia da aprendizagem. Rio de Janeiro: Ed. Vozes, 1997.

[17] Sociedade dos Poetas Mortos. Produção de Peter Weir. EUA: Abril Vídeo, 1989. Filme (128 minutos). 


\section{Capítulo 16}

Direito e comunicação: Análise da relação entre língua portuguesa e comunicação não-verbal $e$ a atuação profissional do bacharel em direito sob a perspectiva dos alunos de uma IES particular de Fortaleza (CE) 22

\section{Raquel Figueiredo Barretto}

Afonso de Deus Nunes Neto

Resumo: Introdução: A comunicação não-verbal antecede a comunicação verbal. 0 sistema judiciário tem, entretanto, privilegiado o enfoque à escrita. Objetivo: analisar a relação entre comunicação não-verbal, língua portuguesa e a atuação profissional do bacharel em direito. Metodologia: Foi realizada, no primeiro semestre de 2016, uma pesquisa de campo, analítica, exploratória com abordagem qualitativa. A coleta de dados deu-se através da produção de textos dos alunos da disciplina de redação e comunicação jurídica. A análise dos dados deu-se através da análise de conteúdo de Bardin (1978). Resultados: A linguagem não verbal é muito importante para a atuação do bacharel em direito: a cor da roupa escura usada pelos operadores do direito transmitiria solidez, seriedade; o anel de rubi transmitira sabedoria e conhecimento; bons carros e imponentes escritórios transmitiriam a impressão de sucesso ao cliente. Os alunosinformantes reconhecem a importância da língua portuguesa erudita para o curso de direito tanto quanto a necessidade de domínio de conteúdo técnico pelos bacharéis. Ressaltam ainda o quanto o domínio da língua portuguesa culta denota credibilidade perante os pares e clientes. Conclusão: A comunicação não verbal é muito importante para a comunicação jurídica. Especificamente em concursos da carreira jurídica e na carreira jurídica, o domínio do conjunto léxico de regras gramaticais torna-se o principal aliado do pretendente ao cargo público e uma necessidade básica ao futuro bacharel.

Palavras-chave: Comunicação; Comunicação não-verbal; Língua Portuguesa; Direito.

Artigo já foi publicado nos Anais do evento III CONEDU (Congresso Nacional de Educação) 


\section{INTRODUÇÃO}

A comunicação não-verbal antecede a comunicação verbal. Embora a comunicação não-verbal tenha despertado pouco interesse dos estudiosos da linguagem jurídica, não se nega sua existência em nosso meio, cuja relevância algumas vezes reflete na linguagem escrita e falada (COSTA, 2003).

$\mathrm{O}$ sistema judiciário tem privilegiado o enfoque à escrita. Portanto, a atividade jurisdicional se reduziu a um processo de comunicação quase exclusivamente escrita: juízes, advogados, promotores e escrivães parecem seres cujo único meio de comunicação é a escrita. As reclamações jurídicas, os depoimentos de partes e testemunhas precisam-se converter à linguagem escrita e assim perdem muito em substância. Os tribunais valorizam mais a documentação dos julgados, sempre na linguagem escrita. "A linguagem não traduz imagens verbais de origem motora e sensorial nem representa ideias feitas por um pensamento silencioso, mas encarna as significações. As palavras têm sentido e criam sentido." (CHAUÍ, 2004, p. 156). A carreira jurídica, por sua vez, tem como objetivo de uso a palavra. 0 bom uso da Língua Portuguesa é essencial para a carreira jurídica. O domínio da Norma Culta Padrão melhora a performance do profissional de Direito quando do exercício da profissão (GONÇALVES E CARNEIRO, 2008).

\section{OBJETIVO}

Esta pesquisa teve como objetivo analisar a importância da língua portuguesa para o curso de direito e analisar a relação entre comunicação não-verbal e a atuação profissional do bacharel em direito.

\section{FUNDAMENTAÇ̃̃O TEÓRICA}

\subsection{ASPECTOS NÃO VERBAIS}

São frequentes os ícones jurídicos: balanças e espadas empunhadas por estátuas de feições angelicais são versões profanas dos arquétipos de virtude das divindades greco-romanas.

O significante em ambas também coincide: a crença na igualdade dos homens e num sentimento de Justiça acima deles. Um segundo elemento marcante da comunicação não-verbal no Judiciário é o rigor indumentário.

Talvez apenas as religiões tradicionais se comparem aos rigores dos paramentos dos rituais forenses. Um sacerdote e um juiz em suas vestimentas se confundem. Por último, um importante traço da comunicação não-verbal no Judiciário é a linguagem do corpo. A comunicação gestual na instituição também parece fincar raízes em posturas monásticas que aderem inconscientemente à figura do magistrado e seus auxiliares. A sisudez da deusa Têmis parece encarnar no magistrado, tornando-o à semelhança de outras referências da cultura judaico-cristã. Não por acaso a divindade nessa cultura é sempre representada, dentre outros papéis, por um julgador que não sorri e não chora, enfim, que jamais exterioriza o menor traço de emoção (COSTA, 2003).

\subsection{LÍNGUA PORTUGUESA}

Sob a perspectiva da palavra, para o advogado, o domínio da escrita da Língua Portuguesa é crucial, não apenas para sua prática forense, como para os muitos certames a que os advogados se submetem, como na segunda fase do exame da OAB (Ordem dos Advogados do Brasil), por exemplo. Muitos, após o exame, percebem que até conheciam a natureza jurídica que envolvia a petição e as questões, no entanto, a ferramenta do bem escrever constitui papel relevante para a conquista da nota mínima que garanta a desejada carteira da OAB, que habilita à advocacia (GONÇALVES E CARNEIRO, 2008).

Há ainda que se discutir duas questões: juridiquês e a língua portuguesa como uma barreira no acesso à justiça (COSTA, 2013).

Acerca da comunicação verbal, há que se reconhecer a necessidade de adequação linguística para que as pessoas menos favorecidas tenham seu acesso à justiça facilitado. 


\section{METODOLOGIA}

Foi realizada, no primeiro semestre de 2016, uma pesquisa de campo, exploratória, analítica com abordagem qualitativa. A coleta de dados deu-se através da produção de textos dos alunos da disciplina de redação e comunicação jurídica do curso de direito da FANOR. A análise dos dados deu-se através da análise de conteúdo de Bardin (1978). Os aspectos éticos, conforme resolução 466/2012, foram respeitados.

\section{RESULTADOS}

De acordo com as informações presentes nos textos dos alunos-informantes, a linguagem não verbal é muito importante para a atuação do bacharel em direito. Segundo os informantes, a cor da roupa escura usada pelos operadores do direito transmitiria solidez, seriedade. 0 anel de rubi transmitira sabedoria e conhecimento. Bons carros e imponentes escritórios transmitiriam a impressão de sucesso ao cliente.

Os alunos-informantes do curso de direito reconhecem a importância da língua portuguesa erudita para o curso de direito tanto quanto a necessidade de domínio de conteúdo técnico pelos bacharéis. Ressaltam ainda o quanto o domínio da língua portuguesa culta denota credibilidade perante os pares e clientes. Houve ainda o relato do quanto à língua portuguesa pode ser matéria decisiva numa prova de concurso público. Segundo ainda um dos informantes, deveria haver uma prova de língua portuguesa no exame da ordem.

\section{CONCLUSÃO}

Especificamente em concursos da carreira jurídica e na carreira jurídica, o domínio do conjunto léxico de regras gramaticais torna-se o principal aliado do pretendente ao cargo público e uma necessidade básica ao futuro bacharel. A comunicação não verbal é muito importante para a comunicação jurídica.

A linguagem do corpo na vida judiciária revela muito do julgador em seu contato com partes e servidores da secretaria. Um interrogatório com o olhar direto nos olhos transmite e recebe muito para a busca da verdade material. Inconscientemente, uma leve inclinação do julgador em direção à parte pode traduzir total atenção, enquanto um retraimento claramente demonstra aversão ao interlocutor. Os estudiosos da linguagem corporal no cotidiano forense costumam citar o julgamento dos Sete de Chicago, em 1919, como ilustração da existência dessa forma de comunicação inconsciente. (COSTA, 2003)

\section{REFERENCIAS}

[1] Bardin, L. Análise de Conteúdo. Lisboa, Portugal; Edições 70, LDA, 1978.

[2] Costa, Marcelo Dolzany da. A Comunicação E O Acesso À Justiça. R. CEJ, Brasília, n. 22, p. 13-19, jul./set. 2003. Disponível em http://www.jf.jus.br/ojs2/index. php/revcej/article/viewFile/558/738. Acesso em : 02 de Jun. de 2016.

[3] Chauí, M. Convite à Filosofia. 13. ed. São Paulo: Ática, 2004. 424 p.

[4] Gonçalves, Jonas Rodrigo; CARNEIRO, Débora Ferreira. A influência do uso correto da norma culta da língua portuguesa para o direito. Revista Processus de Estudos de Gestão, Jurídicos e Financeiros - Ano 3 - Edição № 07. Disponível em: http://institutoprocessus.com.br/2012/wp-content/uploads/2012/07/1\%C2\%BA-artigo-JonasRodrigo-Debora.pdf. Acesso em : 02 de Jun. de 2016. 


\section{Capítulo 17}

\section{Gêneros e tipologias textuais na escola: Alternativas didáticas com o diário de leituras ${ }^{23}$}

\section{Geam Karlo Gomes}

Josimere Maria da Silva

Josefa Maria dos Santos

Resumo: Nesse estudo, busca-se fazer uma releitura dos autores que tratam das concepções de gênero e tipologia textual, buscando compreender de que forma esse conhecimento pode permitir práticas escolares que contribuam para as aprendizagens e se aproximem das situações reais de comunicação. Visando contemplar essa perspectiva, propomos fazer algumas sugestões metodológicas a partir do diário de leituras, que é um gênero capaz de favorecer a revisão bibliográfica, a leitura crítica e o hábito de estudo individual, entre outras contribuições.

${ }^{23}$ Este capitulo é uma versão ampliada do artigo "Práticas de leitura e escrita a partir da noção de gêneros e tipos textuais: um enfoque sobre o diário de leitura", apresentado no IV SINALGE - Simpósio Nacional de Linguagens e Gêneros Textuais (2017). 


\section{INTRODUÇÃO}

Surgida primeiramente no domínio da literatura, a classificação dos gêneros textuais segue a orientação teórica bakhtiniana. Segundo esse teórico, a língua se manifesta a partir de enunciados (orais e escritos) e se apresenta em distintos modelos de atividade comunicativa. Outrossim, os inúmeros gêneros textuais existentes também corroboram para a percepção de que eles são tipologicamente heterogêneos.

Numa perspectiva sociointeracionista, a inserção do estudo, análise e produção de gêneros textuais na escola é uma tarefa significativa e positivamente enriquecedora de múltiplas aprendizagens. Para Schneuwly e Dolz (1994), na escola, lugar privilegiado e autêntico de comunicação, os gêneros são resultados de como funciona a comunicação escolar, segundo as suas especificidades linguísticas e discursivas. Neste sentido, este texto objetiva mostrar a importância da perspectiva sociointeracionista da linguagem e as noções de gênero e tipo textual próprios dos estudos da linguística textual para o desenvolvimento de práticas de leitura e escrita no ambiente escolar. Para isso, busca-se fazer uma releitura dos autores que tratam das concepções de gênero e tipologia textual, buscando compreender de que forma esse conhecimento pode permitir práticas escolares que contribuam para as aprendizagens e se aproximem das situações reais de comunicação.

Visando contemplar essa perspectiva, propomos ainda algumas sugestões metodológicas a partir do diário de leituras, que segundo Machado et al, (2007), é um gênero capaz de favorecer a revisão bibliográfica, a leitura crítica e o hábito de estudo individual, entre outras contribuições.

\section{O TEXTO: DAS FORMAS AOS GÊNEROS}

De acordo com a finalidade do interlocutor, o texto pode se apresentar materializado em formas e modelos variados. Essa distinção se deve aos variados propósitos comunicativos. No entanto, os modelos não são formas engessadas e estáveis, nem tampouco nasceram prontos. Mesmo antes de considerar a existência da escrita, é possível perceber a diferença na estrutura dos enunciados na modalidade oral; característica que perdura atualmente. Um diálogo entre duas ou mais pessoas em uma palestra para um grande público, por exemplo, apresenta diferenças pontuais em relação a uma conversa informal.

Remontando à época cristã, pensadores gregos de grande prestígio, os sofistas, exerciam a retórica de forma remunerada, visando à persuasão para se (auto)enaltecer ou mesmo diminuir o outro. Com grande crítica, Aristóteles (384 a. C 322 a. C.) condena essa técnica, defendendo a busca da essência e da verdade. Por meio da obra $A$ arte retórica, ele classifica os processos persuasivos em três gêneros distintos: judiciário (quando se pretende defender ou acusar alguém), deliberativo (abrir decisão para o auditório); e demonstrativo (com a finalidade de ressaltar os méritos ou mesmo criticar os defeitos de alguns sujeitos).

Por conseguinte, a classificação dos gêneros textuais surgiu primeiramente no domínio da literatura. Ainda na Antiguidade, Aristóteles observou os gêneros quanto à forma (verso e prosa) e conteúdo, dando origem aos gêneros lírico, épico e dramático. Essa classificação surge então nos manuais de literatura e livros didáticos diversos, corroborando, muitas vezes, para a primeira ideia, aparentemente equivocada, que o estudante apresenta a respeito do conceito de gênero.

Outro equívoco possui raízes na prática com a redação escolar. Por muito tempo, a ideia de produção textual, chamada de redação, deveria estar associada às categorias tradicionais de narração, descrição e dissertação. Essa classificação foi, durante muito tempo, utilizada como paradigma para o ensino de produção textual, confundindo-se com os modelos para comunicação nos diversos âmbitos sociais: os gêneros textuais. Tal concepção é oriunda da tentativa de caracterizar as tipologias textuais como gêneros textuais. A dissertação escolar, por exemplo, gênero textual frequentemente exigido em avaliações externas como o ENEM e os vestibulares foi durante muito tempo trabalhada na escola com a nomenclatura de dissertação, distinta das categorias narração e descrição. Ora, mesmo possuindo a predominância da sequência tipológica argumentativa, a dissertação escolar poderá apresentar também sequências narrativas, descritivas e expositivas, entre outras. Para fundamentar um trabalho voltado para o estudo, produção e análise de textos, há, sem dúvidas, a necessidade de definir com precisão a distinção entre gênero e tipo textual. Inclusive como forma de aprimorar as competências de leitura e escrita.

Mediante uma suscinta revisão bibliográfica, apontamos as concepções de gênero e tipo textual, buscando explicitar de que forma essa compreensão pode favorecer uma prática de leitura e escrita propícia a uma prática sociointeracionista. Sem dúvidas, o trabalho com o gênero textual diário de leituras é uma alternativa bastante fecunda. 


\section{DIFERENCIANDO GÊNEROS TEXTUAIS DAS SEQUÊNCIAS TIPOLÓGICAS}

Conforme apresenta Bakhtin (1997), a língua se manifesta por meio de enunciados, tanto orais quanto escritos. Os enunciados apresentam modelos distintos que integram a atividade humana. Assim, o que denominamos gênero textual foi, primeiramente, considerado como esfera de utilização da língua. Sua riqueza é infinita e comporta um repertório que vai se diferenciando de acordo com a atividade comunicativa e está sujeito à complexidade de cada esfera de comunicação. Essa natureza depende de como se manifestam os enunciados.

Segundo Bakhtin,

o enunciado reflete as condições específicas e as finalidades de cada uma dessas esferas, não só por seu conteúdo (temático) e por seu estilo verbal, ou seja, pela seleção operada nos recursos da língua recursos lexicais, fraseológicos e gramaticais mas também, e sobretudo, por sua construção composicional. Estes três elementos (conteúdo temático, estilo e construção composicional) fundemse indissoluvelmente no todo do enunciado, e todos eles são marcados pela especificidade de uma esfera de comunicação (Bakhtin, 1997, 280).

Com posição similar a Douglas Biber (1988), John Swales (1990), Jean-Michel Adam (1990) e Jean Paul Bronckart (1999), Marcuschi (2010) faz uma distinção entre tipo e gênero textual. Para compreender a natureza de um tipo textual, busca-se encontrar a sequência definida teoricamente por sua composição. Alguns autores divergem na classificação dessas categorias: seis ou sete tipologias. Adotamos, assim como Marcuschi: a narração, a argumentação, a exposição, a descrição e a injunção, que apresentam aspectos lexicais, sintáticos e tempos verbais por naturezas linguísticas semelhantes; pois parecem contemplar todas as sequências disponíveis em sua natureza distintiva.

Assim, com base na sugestão de Werlich (1973), Marcuschi (2010) aponta cinco bases temáticas textuais típicas que dão origem aos tipos textuais: descritiva (com verbo estático no presente ou imperfeito, com complemento ou indicando circunstância de lugar); narrativa (com verbo de mudança no passado e um circunstancial de tempo e lugar, com enunciado indicativo de ação); expositiva (enunciado de identificação de fenômenos, estrutura com um sujeito, um verbo da família do verbo ter, contém, consiste, compreende e um complemento que estabelece com o sujeito uma relação parte-todo); argumentativa (forma verbal no presente e um complemento, com atribuição de qualidade, entre outros aspectos); e injuntiva (representada por um verbo no imperativo e incitadores à ação). São essas as principais entre outras características presentes em cada sequência tipológica.

Por outro lado, a chave para se compreender o gênero textual são as características sociocomunicativas: estilo, propriedades funcionais, conteúdos e composição. São inúmeros os gêneros:

bilhete, carta de leitor, carta ao leitor, carta de reclamação, e-mail, poema, cordel, videopoema, poemavisual, contos (de suspense, mistério, terror, humor) narrativa de enigma, crônica liteária, crônica esportiva, crôncia histórica, discurso de defesa, discurso de acusação, história em quadrinhos, novela, teatro, fábula, lenda, romance, memória literária, sermão, receita culinária, ofício, lei, requerimento, regulamento, edital, manual de instruções, memorando, boleto bancário, artigo científico, artigo de divulgação científica, vídeos de divulgação científica, relato de experimento, comentário, monografia, relatório científico, seminário, conferência, palestra, tomada de notas, relato de viagem, relato de experiência, testemunho, abaixo-assinado, petição on-line, fotorreportagem, fotodenúncia, esquema, mapa conceitual, infográfico estático, infográfico animado, diário de bordo, diário de leituras, diário de classe, diário íntimo, biografia, currículo vitae, ensaio, sinopse, quarta-capa, biodata, letra de canção, notícia, reportagem impressa, reportagem radiofônica, reportagem televisiva, entrevista, artigo de opinião, editorial, recado, aviso, charge, cartum, tirinha, mangá, meme, anúncio publicitário, fanzine, regras de um jogo, dissertação escolar, lista de compras, resenha, verbete de dicionário, lista telefônica, códigos, verbete de enciclopédia (impresso e digital), marginália, resumo de artigo científico, resumo didático, teste escolar, debate público, relato multimidiático de campo, epitáfio, provérbio, classificados, paródia, cardápio de um restaurante, bula de medicamento, piada, aula, telefonema, cartaz, folheto, fanclipe, detonado, outdoor, banner, gameplay, trailer, e-zine, videoclipe, panfleto, busdoor, propaganda, podcast, vlog, blog, spot, jingle, vídeos, fóruns, bate-papo... e essa lista está longe de finalizar. 
Ora, desde a invenção da escrita alfabética no século VII a.C até os dias atuais, os gêneros se multiplicaram em função das necessidades variadas de comunicação. E com a criação das várias mídias, tanto impressas como da cultura eletrônica em especial, a internet, as formas e modelos de comunicação se tornaram infinitas; sofrendo a ação das mais variadas formas e finalidades de comunicação.

Para Marcuschi, os gêneros textuais ordenam as atividades comunicativas cotidianas. Em meio à interação criativa do homem sobre o mundo, os gêneros são dinâmicos, maleáveis e de plasticidades que permitem reconfigurações. Ao mesmo tempo, são ferramentas de comunicação entre os sujeitos a partir de modelos disponíveis na sociedade. Na realidade, os gêneros textuais são caracterizados mais por "suas funções comunicativas, cognitivas e institucionais do que por suas peculiaridades linguísticas e estruturais" (Marcuschi, 2010, p. 20). Esse posicionamento é fruto de uma corrente que considera a concepção dos gêneros discursivos, postulados por Bakhtin. A teoria desse filósofo russo influenciou o pensamento ocidental a partir de uma concepção de linguagem que não segue um paradigma estruturalista. Do contrário, firma-se numa perspectiva de que a linguagem é um instrumento no qual o sujeito sóciohistórico interage no meio em que vive. 0 texto é visto como produto das interações sociais relacionadas à situação material concreta. Nesse sentido, um indivíduo não pode se utilizar da comunicação verbal a não ser por meio de um gênero textual, seja oral ou escrito. De forma geral, Marcuschi (2010) enfatiza que os gêneros são caracterizados por um dos dois principais aspectos: formais e sociocomunicativos ou funcionais. Por essa razão, há gêneros que são determinados facilmente pela forma; e outros, por suas funções sociocomunicativas.

No que se refere aos estudos dos gêneros textuais, têm crescido vertentes distintas, com peculiaridades também diferentes. Entretanto, muitas vezes estes estudos convergem, tendo em vista o diálogo existente entre as abordagens de variados teóricos. A presente proposta busca unir os trabalhos de Bakhtin, as contribuições vygostskyanas do socioconstrutivismo e da Escola de Genebra, sobretudo, em torno de Schneuwly e Dolz, associando também ao interacionismo sociodiscursivo de Bronckart. No diálogo com esses teóricos, consideramos a perspectiva do sociointeracionismo, compreendendo que esse termo contempla os objetivos propostos que defendemos nesta abordagem.

\section{OS GÊNEROS TEXTUAIS NA PERSPECTIVA SOCIOINTERACIONISTA}

Com base nas teorias e concepções de Bakhtin e Vygotsky sobre a linguagem, aprendizagem e desenvolvimento do sujeito, o tema dos gêneros textuais ganha destaque no currículo nacional brasileiro. As escolhas teóricas tiveram como modelo as contribuições teóricas do grupo de Genebra: Bernard Schneuwly e Joaquim Dolz. Esses autores se embasam nas concepções de gêneros do discurso de Bakhtin para formular uma proposta de trabalho com a produção de textos a partir da perspectiva da natureza sociointeracionista e linguística dos gêneros textuais. A caracterização dos gêneros textuais, segundo Dolz e Schneuwly, deve ser feita a partir de três dimensões: os conteúdos e os conhecimentos que eles encerram, a estrutura comunicativa e semiótica inerente à partilha do texto e as configurações de unidades de linguagem específicas, "posição enunciativa do enunciador e dos conjuntos particulares de sequências textuais e tipos discursivos que formam sua estrutura" (Schneuwly; Dolz, 1999, p. 7).

Batier (1995 apud Schneuwly; Dolz, 1999), conceituando as práticas de linguagem e seu funcionamento no que diz respeito à relação dos aprendizes com tais práticas, esclarece que elas implicam três dimensões de funcionamento tendo em vista uma situação comunicacional particular. São elas as dimensões: social, cognitiva e linguística. Com a mediação entre o sujeito e o meio, a linguagem assume papel decisivo e determinante nas ações dos sujeitos. Desta forma, é por meio da linguagem que se tornam possíveis a partilha dos conhecimentos, a cooperação entre os indivíduos e as mais variadas formas de interação humana.

Segundo as contribuições de Bronckart, Shneuwly e Dolz, as atividades de linguagem podem ser decompostas em ações, ou seja:

[...] estruturas de comportamento não diretamente articuladas aos motivos, mas orientadas por objetivos intermediários que advêm da vontade consciente e que implicam uma representação de seu efeito no âmbito da cooperação e da interações sociais (Bronckart, 1996 apud Schneuwly; Dolz, 1999, p. 6).

Ainda conforme apontamentos desses estudiosos, ao sujeito compete esforçar-se para adaptar-se ao contexto, ao referente e às unidades linguísticas, buscando-os compreender, interpretar os enunciados ou produzir outros. É nessa interação que são mobilizados os modelos discursivos já presentes na sociedade letrada. Por meio dessas ações, o sujeito faz uma escolha do gênero textual que é a forma mais ou menos 
estável de materialização do discurso em conformidade com a situação comunicativa, com os objetivos pretendidos e com os papéis dos interlocutores.

Ingedore G. Villaça Koch, citando Bronkcart, afirma:

Uma ação de linguagem exige do agente produtor uma série de decisões, que ele necessita ter competência para executar. Tais decisões referem-se, em primeiro lugar, à escolha do gênero mais adequado, além de outras relativas à constituição dos mundos discursivos, à organização sequencial ou linear do conteúdo temático, à seleção de mecanismos de textualização e de mecanismos enunciativos (Bronckart, 1984, apud Koch, 2015, p. 65).

Ora, essa observação é um forte indicador da necessidade de inserir a abordagem dos gêneros textuais no espaço escolar. Professores e estudantes devem perceber a importância de tais instâncias para fortalecer a aprendizagem em todas as áreas. Se a interação humana não é algo possível a não ser por meio de um gênero textual, a escola deve ser um espaço não só de estudo dos gêneros, mas da prática social dos mesmos. Assim, tanto professores quanto estudantes precisam compreender bem a natureza, as especificidades e o funcionamento da linguagem na interação social.

\section{AS PRÁTICAS DE LEITURA E ESCRITA DE GÊNEROS NA ESCOLA}

Um dos problemas emergentes no tocante ao tratamento dado aos gêneros textuais no âmbito escolar diz respeito à forma de abordagem. Antes de qualquer coisa, é preciso entender que há gêneros tipicamente usados na escola, e outros que são utilizados no espaço extraescolar. Resenhas, resumos, redação escolar, fichamento, entre outros, são tipicamente produzidos na escola. Contudo, é preciso admitir que há resumos e resenhas cujas finalidades discursivas vão além do ambiente da escola. $\mathrm{E}$ o que dizer dos gêneros jornalísticos, que não são associados ao contexto sociocomunicativo essencialmente da escola, mas que frequentemente são estudados nas aulas de Língua Portuguesa, com foco na leitura, na compreensão e na produção textual? Essas indagações nos conduzem à reflexão sobre a própria natureza sociocomunicativa dos gêneros textuais. Em que momentos a escola, de fato, estuda os gêneros na sua natureza real de interação ou em que ocasião o gênero é destituído de sua finalidade e vínculo com o social e tratado como "pseudo" texto, com o único propósito da didatização escolar em atividades que privilegiam apenas os aspectos linguísticos, desnaturalizando os gêneros textuais da real situação comunicativa.

Defendendo a natureza social dos gêneros, Carolyn Miller (1984) aponta que eles são mais que formas linguísticas, são situações sociais particulares. Conforme citado por Marcuschi: "os gêneros são formas verbais de ação social estabilizadas e recorrentes em textos situados em comunidades de práticas em domínios discursivos específicos" (Miller, 1984 apud Marcuschi, 2008). E acrescenta resumidamente que os gêneros textuais são entidades:

[...] dinâmicas, históricas, sociais, situadas, comunicativas, orientadas para fins específicos, ligados a determinadas comunidades discursivas, ligados a domínios discursivos, recorrentes e estabilizadas em formatos mais ou menos claros (Marcuschi, 2008, p. 159).

Entendido assim, os gêneros podem se tornar ferramentas potencializadoras para o trabalho com a leitura e a escrita na escola. Não só porque os estudantes estarão lidando com textos reais, oriundos de contextos discursivos e finalidades comunicativas específicas, mas, principalmente, porque terão a oportunidade de lidar com os gêneros também em situações reais de comunicação.

Para que isso ocorra, faz-se necessário evitar determinadas práticas. No dizeres de Schneuwly e Dolz, são momentos em que "o aluno encontra-se, necessariamente, num espaço do como se, em que o gênero funda uma prática de linguagem que é, necessariamente, em parte, fictícia", visto que serve apenas para fins da aprendizagem (Schneuwly; Dolz, 1999, p. 7, grifo nosso) e não se concretiza como situação de comunicação efetiva. Conforme os autores, nesse tipo de prática a finalidade é o domínio da pura forma linguística, com a única e exclusiva finalidade de avaliar a capacidade de escrita dos estudantes; o que caracteriza a escrita como representação do real e não a situação autêntica de comunicação.

Segundo esses representantes da Escola de Genebra, os gêneros textuais são um mega- instrumento para situações de comunicação, e por possuir um caráter genérico, são referências para os aprendizes. Sendo assim, questionam o lugar efetivo dos gêneros no âmbito escola. Diríamos, não o lugar, mas o tratamento que eles merecem em virtude da necessidade de estudar toda riqueza que eles oferecem, sem descartar 
sua natureza sociocomunicativa.

Koch (2015), corroborando com Schneuwly e Dolz, defende que há pelo menos três maneiras de abordar a produção textual na escola. A primeira se assemelha ao que já fora explicitado anteriormente, cujo gênero é visto como forma linguística com finalidade de dominar as sequências estereotipadas: descrição, narração e a dissertação. Por meio desta concepção, o ensino não considera os gêneros como práticas sociais.

A segunda é a que mais se aproxima das situaçõesreais de interação. Nela,

a escola é tomada como autêntico lugar de comunicação e as situações escolares como ocasiões de produção/recepção de textos. As ocasiões de produção de textos se multiplicam: na classe, entre classes, entre escolas - texto livre, correspondência escolar, jornal da classe, da escola, murais etc. Os gêneros são, portanto, resultado do próprio funcionamento da comunicação escolar e sua especificidade é o resultado desse funcionamento. Há também uma naturalização, mas de outra ordem: situação de comunicação é vista como geradora quase automática do gênero, que não é descrito ou ensinado, mas aprendido pela prática escolar. Aprende-se a escrever, escrevendo, numa progressão que se constitui segundo uma lógica que depende tão somente do processo interno de desenvolvimento (Schneuwly; Dolz, 1994 apud Koch, 2015, p. 67-68).

Na terceira, nega-se que a escola seja um espaço particular de comunicação. Preocupam-se em diversificar a escrita, em criar situações comunicativas para levar o estudante a perceber como de fato os gêneros funcionam nas práticas de linguagem. 0 ensino visa aqui o domínio das ferramentas necessárias para que o estudante tenha progresso na interação com as diversas práticas de linguagem.

Com destaque, é preciso salientar que deve haver um ponto de contato entre a segunda e a terceira perspectiva. Admitir que se aprende a escrever escrevendo é um posicionamento frutífero e muito positivo, tanto para o progresso dos estudantes, quanto para fazer da escola um espaço realmente interativo, e, em consequência, significativo de aprendizagem.Contudo, o ambiente escolar não pode lançar mão do acaso. As práticas precisam de planejamento, e o professor é o mediador de tais práticas, inclusive deve estar preparado para as intervenções, quando necessárias. No entanto, é preciso dosar esse posicionamento para não desvincular a prática interativa do processo de produção. 0 professor se coloca também na posição de apontar os caminhos, sugerir as ferramentas e orientar os procedimentos que serão utilizados pelos estudantes em suas práticas.

Assim, tomar o gênero como objeto de trabalho requer:

colocar os alunos, ao mesmo tempo, em situações de comunicação que estejam o quanto mais próximas de verdadeiras situações de comunicação, que tenham um sentido para eles a fim de melhor dominá-las como realmente são (Schneuwly; Dolz, 1999, 10-11).

É inegável que nas práticas com tais gêneros as competências de leitura e escrita estão totalmente imbricadas. Difícil dissociar a leitura da escrita a não ser de forma meramente didática. Escrever requer leitura e a leitura proporciona uma ampliação de habilidades que irão interfeir positivamente nas novas produções escritas.

Visando subsidiar o professor quanto ao ensino dos gêneros e também a partir dos gêneros isso porque compreendemos que há várias competências e habilidades na escola que são tratadas por meio de algum gênero textual o trabalho escolar com os gêneros deve ser bem pensado, tanto no sentido de ampliar a capacidade de comunicação dos estudantes, de melhorar sua competência leitora, e, consequentemente, de escrita; quanto no tocante à preocupação de não fazer das práticas escolares uma série de exercícios desvinculados das formas autênticas de comunicação.

Nesse intuito, torna-se evidente que o trabalho com os gêneros não só é uma ferramenta que permite ressignificar as práticas escolares, ao proporcionar o aprendizado a partir de situações reais de comunicação, como também possibilita o entrelaçamento do conhecimento teórico relativo à especificidade do gênero e sua natureza social, linguística e cognitiva, com as diversas formas de colocálos em funcionamento na prática. 0 aprendizado teoria/prática se tornará um efetivo instrumento para os estudantes, contribuindo para seu aprendizado, no que se refere à sua formação social, cognitiva, cultural, psicológica e linguística. 


\section{DIÁRIO DE LEITURAS: UMA ALTERNATIVA DIDÁTICA}

De caráter intimista, o diário de leituras pode torna-se um instrumento potencial para múltiplas aprendizagens no ambiente escolar, favorecendo alternativas didáticas que podem contribuir para tornar a sala de aula um espaço real de interação social. Sua produção envolve disposição para elaboração de sínteses e paráfrases, que podem gerar expressões de sentimentos, reações, críticas e julgamentos. Como define Anna Rachel Machado, "é um texto produzido por um leitor, à medida em que lê, com o objetivo maior de dialogar [...] com o autor do texto, de forma reflexiva" (Machado, 2005, p.64).

Barriceli (2018) amplia esse conceito a partir de um entrevista fictícia com a referida autora:

0 Diário é um texto no qual o leitor vai registrando, à medida que lê, da forma mais livre possível e pessoal, sua compreensão, suas impressões pessoais, seus problemas de compreensão diante do texto que está lendo, as relações que vai estabelecendo entre os conteúdos do texto e seus conhecimentos e experiências pessoais, suas concordâncias e discordâncias com o autor, etc. Do ponto de vista da linguagem de cunho interacionista sociodiscursiva, o Diário pode ser visto como um processo de interação entre um leitor ativo e um texto, no qual, as características do leitor interagem com as do texto para produzir uma significação específica ao contexto no qual a atividade de leitura se realiza (Barriceli, 2018, p.26).

Como instrumento para prática educativa, o DL é, sem dúvidas, uma alternativa para o desenvolvimento do trabalho com a leitura e com a produção escrita em sala de aula, contribuindo para a formação do leitor crítico e proficiente. Se o conhecimento dos gêneros textuais antecipam expectativas que favorecem a compreensão sobre o texto, o DL é um gênero que nasce iminentemente das impressões sobre cada texto lido. E não se pode negar que o reconhecimento do gênero textual interfere no posicionamento do leitor/produtor do DL: um romance ou um poema potencializa emoções variadas; um artigo, uma reportagem, um editorial, uma entrevista são artefatos culturais repletos de conhecimentos sobre os quais se podem suscitar reflexões, dúvidas, deduções, entre outros. Quem nunca discordou de uma resenha crítica sobre um filme ou livro que tenha assistido/lido? Os julgamentos e impressões sobre um determinado texto lido é marca constituinte de um DL, como se nota no trecho seguinte:

De 'início fiquei - atônico ' ao'ver" as" catástrofes" naturais" no' nosso' planeta... 'Agora' sombrio, ' a. humanidade

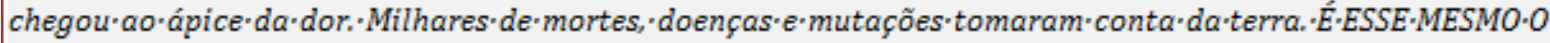

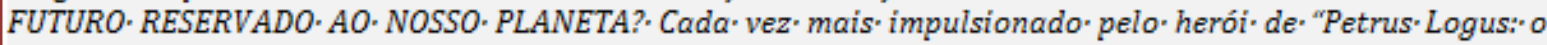

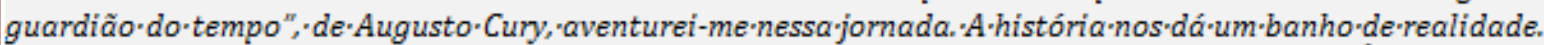
O. autor parece alertar. sobre o. mal que $\alpha \cdot$ humanidade está causando à natureza. SERÁ. O. FUTURO

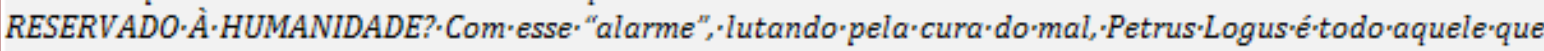

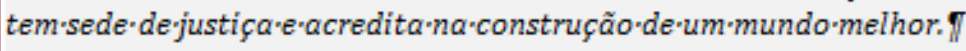

(manuscritos: de.T.V.'S. -G.)

Nesse sentido, o DL é um gênero textual que tanto se efetiva numa prática social de escrita, quanto possibilita o reconhecimento e a interação sociodiscursiva com outros gêneros. É um gênero que redimensiona o papel do discente em sala de aula. Como apresentamos em trabalho recente, o DL é um instrumento de leitura analítica e crítica. Isso porque,

[...] ao ler escrevendo, o estudante sai da condição de mero receptor do texto e passa a ser "coprodutor" do discurso lido, questionando o autor, suas posições ideológicas, fazendo relação do conteúdo com outros conhecimentos prévios, apresentando suas dúvidas ou descobertas (Rios e Karlo-Gomes, 2019, p. 265).

Dessa forma, torna-se favorável uma proposta onde o DL possa fazer parte do cotidiano escolar, ao considerar que ele também "abre espaço para diferentes vozes, onde os diversos discursos podem circular, contribuindo para a democratização do conhecimento e a formação crítica" (Pires e Karlo-Gomes, 2018, p.281).

A seguir, apresentamos algumas sugestões metodológicas em formato de oficinas, visando à didatização desse gênero na escola. Em cada estratégia realizada, os estudantes são orientados a escrever livremente suas impressões, julgamentos, emoções ou críticas para compor o DL. 


\begin{tabular}{|c|c|}
\hline Oficinas & cações para a aprendizagem \\
\hline $\begin{array}{l}\text { Plenária dos gêneros } \\
\text { Leitura de textos de diferentes gêneros textuais com } \\
\text { a socialização dos diários produzidos em plenária, } \\
\text { apontando título, autor e suas impressões. }\end{array}$ & $\begin{array}{l}\text { Reconhecer que a leitura de diferentes gêneros } \\
\text { textuais suscitam modos e posicionamentos de leitura } \\
\text { distintos. }\end{array}$ \\
\hline $\begin{array}{l}\text { O círculo dentro do círculo. } \\
\text { Sortear notícias e contos para leitura individual em dois } \\
\text { círculos: círculo dos contos e círculo da notícia. O círculo } \\
\text { menor dentro do maior. Após produção do Diário, os } \\
\text { estudantes alternam de círculo: ficarão no centro interno } \\
\text { para socialização da produção; e no externo, para apreciar } \\
\text { (como ouvintes). }\end{array}$ & $\begin{array}{l}\text { Identificar marcas discursivas presentes nas reações } \\
\text { sobre o texto real e o fictício. } \\
\text { Apontar em quais Diários há predominância da } \\
\text { linguagem denotativa ou conotativa. } \\
\text { Comparar o grau de influência da linguagem literária } \\
\text { (do conto) na produção dos diários. }\end{array}$ \\
\hline $\begin{array}{l}\quad \text { Diário e Sinopse } \\
\text { Montar uma sessão de cinema de um filme apropriado para } \\
\text { a faixa etária dos estudantes. A produção do Diário deve } \\
\text { ocorrer de forma concomitante. Após texto produzido, } \\
\text { solicitar que comparem com uma sinopse sobre o mesmo } \\
\text { filme. }\end{array}$ & $\begin{array}{l}\text { Confrontar a linguagem utilizada no Diário de leituras } \\
\text { e na sinopse, identificando semelhanças e diferenças } \\
\text { quanto ao vocabulário, às marcas discursivas, ao } \\
\text { conteúdo fílmico apresentado e aos diferentes } \\
\text { propósitos comunicativos oriundos de cada gênero. }\end{array}$ \\
\hline $\begin{array}{l}\text { O gênero-alvo do jornal } \\
\text { Distribuir vários acervos de jornais diferentes na sala de } \\
\text { aula. Os estudantes são orientados a ler um texto de sua } \\
\text { escolha e escrever livremente no Diário. Por fim, os } \\
\text { estudantes socializam a leitura do texto produzido e o } \\
\text { professor questiona sobre qual o gênero e em que } \\
\text { possível caderno/secção do jornal o texto foi selecionado. }\end{array}$ & $\begin{array}{l}\text { Reconhecer os diversos gêneros textuais do domínio } \\
\text { jornalístico. } \\
\text { Identificar o perfil de leitores da turma a fim de traçar } \\
\text { estratégias para incentivar a leitura de outros textos. } \\
\text { Motivar os estudantes à leitura de cada gênero } \\
\text { lido/apresentado, destacando a sua finalidade e função } \\
\text { social. }\end{array}$ \\
\hline \begin{tabular}{|l} 
O texto lido \\
Propor a leitura de textos sobre a mesma temática para \\
cada grupo de estudantes. A produção do Diário é \\
essencialmente uma atividade discursiva individual e cada \\
discente escolhe qual texto quer ler/escrever. Concluído, o \\
professor distribui os Diários produzidos para outro grupo. \\
Junto, entrega também os textos lidos. Os estudantes devem \\
dialogar em grupo para descobrir a qual texto se refere \\
cada Diário.
\end{tabular} & $\begin{array}{l}\text { Identificar o conteúdo temático dos textos } \\
\text { apresentados. } \\
\text { Fazer relação entre os textos, analisando linguagem, } \\
\text { estilo e marcas de subjetividade. } \\
\text { Possibilitar a familiarização com a estrutura de outros } \\
\text { gêneros textuais, percebendo sua composição, estilo e } \\
\text { função social. }\end{array}$ \\
\hline
\end{tabular}

A sugestão de execução dessas oficinas como atividades didáticaspretende ser uma forma de contribuir essencialmente com a motivação de professores ou futuros professores; e não há intenção de colocá-las como receitas atemporais. Com certeza, a vivência dessas estratégias possibilitará a construção de novas oficinas e até mesmo adaptações das mesmas, conforme o grau de escolaridade dos estudantes e a realidade de cada escola/turma.

\section{CONSIDERAÇÕES FINAIS}

A construção de um trabalho educativo em que as aulas de Língua Portuguesa tenham real significado para os estudantes é o intuito de muitos educadores. O DL pretende ser uma alternativa para se chegar a esse fim. Com a perspectiva sociointeracionista da linguagem e o enfoque sobre o estudo e análise dos gêneros textuais, é possível oportunizar uma prática em que a naturalização da escrita, o processo de escrita e a recepção de textos tornem-se constantes e eficazes. A aprendizagem da escrita se constitui, assim, por meio de constantes motivações de leitura através de oficinas diversas. Um trabalho que não só possibilita a ampliação do repertório dos estudantes em relação ao "ter" o que dizer, como também, ao "como dizer"; graças à familiaridade com a diversidade de gêneros textuais lidos. Qual seja, não se pode ignorar que o Diário pode ser um instrumento funcional para o planejamento docente da leitura e da escrita no âmbito escolar, visto que o contato contínuo com a produção dos diários dos discentes serve de diagnóstico a respeito dos saberes dos estudantes: seus pontos fortes e suas dificuldades. 


\section{REFERÊNCIAS}

[1] Bakhtin. Mikhal. Estética da Criação verbal. Trad. Maria Ermantina Galvão G. Pereira. São Paulo: Martins Fontes, 1997.

[2] Barricelli, Ermelinda Maria. Diálogo com Anna Rachel Machado: uma entrevista fictícia a partir de textos não publicados da autora. In: Karlo-Gomes, Geam. (orgs). 0 diário de leituras na escola e na universidade: estudos do gênero e práxis pedagógica. Campinas, SP: Mercado de Letras, 2018. p. 23-32.

[3] Borges, Flávia Giraldo Botelho. Os gêneros textuais em cena: uma análise crítica de duas concepções de gêneros textuais e sua aceitabilidade na educação no Brasil. Revista Brasileira de Linguística Aplicada. Vol. 12 , № 1. Belo Horizonte, 2012.

[4] Dolz, Joaquim; Schneuwly, Bernard. Os gêneros escolares Das práticas de linguagem aos objetos de ensino. Revista Brasileira de Educação, Anped, n. 11, p. 5-16, mai/jun/jul/ago 1999. Disponível:http://anped.tempsite.ws/novo_portal/rbe/rbedigital/Rbde11/Rbde11_03_Bernard_e_Joaquim.pdf Acesso: 15. set. 2019.

[5] Koch, Ingedore Grunfeld Villaça. Desvendando os segredos do texto. São Paulo: Cortez, 2015.

[6] Machado, Anna Rachel. Diário de Leituras: a construção de diferentes diálogos em sala de aula. In: Linha d' Água, v. 18, no 1, pp. 61-80. São Paulo: Companhia das Letras, 2005.

[7] _ et al. Trabalhos de pesquisa: diários de leitura para a revisão bibliográfica. São Paulo: Parábola Editorial, 2007.

[8] Marcuschi, Antônio Luiz. Gêneros textuais: definição e funcionalidade. In: Dionísio, Angela Paiva; Machado, Anna Rachel; Bezerra, Maria Auxiliadora. (Orgs.) Gêneros textuais e ensino. São Paulo: Parábola Editorial, 2010.

[9] _ _ Produção textual, análise de gêneros e compreensão. São Paulo: Parábola Editorial, 2008.

[10] Pires, Auricélia; Karlo-Gomes, Geam. 0 uso de aplicativo digital na produção do diário de leituras: uma prática educativa na área de linguagens. In: Karlo-Gomes, Geam. (orgs). O diário de leituras na escola e na universidade: estudos do gênero e práxis pedagógica. Campinas, SP: Mercado de Letras, 2018. p. 23-32.

[11] Rios, Renata Ferreira; karlo-gomes, geam. O diário de leituras dos quadrinhos: do livro didático às práticas no ensino médio. Revista intersecções. Edição 27, ano 12. Número 1, maio/2019

[12] Zavam, Aurea; Almeida, Nukácia. Gêneros textuais e ensino. Universidade Aberta do Nordeste. Fascículo 5. Fortaleza: Fundação Demócrito Rocha, 2003. 


\section{Capítulo 18}

Estratégias Juri simulado e dramatização: Análise de suas contribuições numa proposta de superação da educação bancária.

\section{Marinalva da Silva Ferreira \\ Marli Teresinha Quartieri \\ Miriam Ines Marchi}

Resumo: Este artigo é resultado de estudos e discussões acerca do processo de ensino e da formação de sujeitos com autonomia e tem como objetivo fazer uma reflexão sobre a importância de diversificar as estratégias de ensino em situações de aprendizagem. Assinala a utilização de estratégias de ensino que valorizem a participação do aluno, a resolução de problemas, a criticidade e a dialogicidade como um dos possíveis caminhos para a superação da concepção da educação bancária, ou seja, a forma de ensino considerada tradicional. Nesse contexto, faz uma análise de duas experiências de situações de aprendizagem de um curso de formação continuada oferecido pela Rede Municipal de Ensino de Imperatriz/MA a estudantes de Pedagogia que atuam como estagiários nas creches da referida Rede. As análises apontaram que as estratégias Júri Simulado e Dramatização possibilitam dar voz ao aluno, apontando indícios de um sujeito mais autônomo nos processos de ensinar e de aprender.

Palavras-chave: Educação; Professores; Estratégias de Ensino; Autonomia.

Trabalho apresentado no Fórum Internacional de Pedagogia 2016 - FIPED. 


\section{INTRODUÇÃO}

Há muito se faz críticas às práticas consideradas tradicionais e centradas no professor como cerne dos processos de ensino e de aprendizagem, principalmente por perceber os novos perfis de homens e mulheres exigidos para a contemporaneidade. É perceptível que o mundo contemporâneo não é o mesmo do século passado e nem tampouco o da modernidade, berço da escola. Diante disso, questiona-se: o que pode ser pensado e proposto como uma possibilidade para que haja uma sintonia entre a escola e os desafios para a formação na contemporaneidade?

É nesse contexto que este artigo se propõe a fazer uma reflexão sobre as práticas pedagógicas tradicionais onde as fórmulas e os conceitos estão prontos para serem memorizados e repetidos pelos alunos, para isso se aponta a utilização de estratégias de ensino que valorizem a participação do aluno, a resolução de problemas, a criticidade e a dialogicidade como possíveis caminhos para a formação de um aluno autônomo de sua própria aprendizagem.

Neste cenário descreve-se e analisa o desenvolvimento de duas situações de aprendizagem nas quais são desenvolvidas estratégias de ensino que promovem a participação ativa e o envolvimento dos alunos nas mesmas. Não se pretende com esta descrição, análise e reflexão dizer que as ideias aqui defendidas sejam as únicas viáveis que levam à possibilidade da formação de sujeitos ativos e autônomos nas situações de aprendizagem e aptos para viverem num mundo de liquidez e sem forma como tem se tornado cada vez mais a sociedade contemporânea.

Embora se reconheça que a temática em estudo já ocupa grande parte da literatura da academia de educação e ensino, ainda se tem a necessidade de continuar discutindo o tema, tendo em vista que o mesmo, embora discutido, ainda não foi superado, pois não é difícil encontrar salas de aulas nas quais as práticas de ensino continuam sendo centradas no professor, com conteúdos inflexíveis e inquestionáveis. Assim, refletir sobre estes desafios e analisar práticas exitosas já desenvolvidas, pode ser uma forma de manter acesa a chama e a esperança de que é possível avançar no sentindo de se garantir a formação de homens e mulheres críticos, ativos, autônomos e capazes de lidar com os desafios da contemporaneidade.

\section{A ESCOLA E DESAFIOS DA CONTEMPORANEIDADE}

Há muito se discute a superação da Educação Bancária ${ }^{24}$ e busca-se a construção de uma escola onde o aluno seja protagonista de sua aprendizagem, onde o aprender seja mais importante que o rigor das disciplinas e das estruturas rígidas de currículos pensado em gabinetes e muitas vezes fora do contexto, social, político e cultural.

Não é difícil perceber que o mundo mudou e continua em permanente processo de mudança. Em razão disso, faz-se necessário pensar numa escola que dê conta de garantir a formação de sujeitos autônomos e ativo nas situações de aprendizagem, para tanto, são imprescindíveis as metodologias que "colocam o aluno diante de problemas e/ou desafios que mobilizam o seu potencial intelectual" (BERBEL, 2011, p. 34). Assim, entende-se que estas metodologias podem permitir a construção da autonomia do educando e contribuir para que o mesmo possa ler e compreender sua realidade e tenha condições de superar desafios.

Todavia, a escola, instituição nascida na modernidade ainda é permeada pelos sentidos, pelos valores, pelas convicções que fora lhe dado ainda na sua gênese e que insiste em permanecer inalterada, com suas características da Idade Moderna, para Sibilia (2012, p. 13):

Não é muito difícil verificar que, aos poucos, essa aparelhagem vai se tornando incompatível com os corpos e a subjetividade das crianças de hoje. A escola seria, então, uma máquina antiquada. Tanto seus componentes quanto seus modos de funcionamento já não entram facilmente em sintonia com os jovens do século XXI.

\footnotetext{
24 Termo cunhado por Paulo Freire para referir-se à Educação Tradicional onde o papel do aluno era passivo e de receptor dos conhecimentos transmitidos pelo professor.
} 
Não se pretende aqui falar das diversas mudanças ocorridas nos mais variados setores como na economia, nos modos de produção ou mesmo do grande avanço tecnológico que a humanidade tem vivido, mas pensar o papel da escola e principalmente o do professor e a sua postura frente aos novos desafios de um mundo em permanente mudança e, que por isso, exige dos homens e mulheres, novas posturas e novas competências pois os saberes deixaram de ser estáticos, prontos e acabados. Nesse contexto, Bauman afirma que:

A educação e a aprendizagem no ambiente líquido-moderno, para ser úteis, devem ser contínuas e durar toda a vida. Nenhum outro tipo de educação e/ou aprendizagem é concebível; a "formação" do próprio eu, ou da personalidade, é impensável de qualquer outro modo que não seja aquele contínuo e perpetuamente incompleto. (BAUMAN, 2009, p.673-674)

Este é um desafio para a escola e para o professor que por muito tempo se perceberam como o detentor do conhecimento. E neste mundo de mudanças, sem formas definidas e fórmulas prontas, sem a segurança da certeza, da permanência que por isso é chamado por Bauman de ambiente líquido-moderno, como ser um professor? Que metodologias podem auxiliar este professor frente ao desafio deste mundo líquido? Provavelmente não serão as metodologias que levam à memorização, à repetição de conceitos, de fórmulas prontas sem questioná-las, sem criticá-las, ou até mesmo sem compreendê-las. Faz-se necessário também antes de decidir pela metodologia refletir sobre que tipo de homem e de mulher queremos formar e em que tipo de sociedade queremos viver.

A postura da escola, e especificamente dos professores, precisa superar as velhas e, muitas vezes, arraigadas práticas pedagógicas centradas num professor autoritário, sem aberturas ao diálogo e detentor do conhecimento; alicerçada na transmissão do conhecimento e na percepção de um aluno passivo num processo vertical de ensino e aprendizagem. A educação precisa focar na formação de homens e mulheres autônomos, nesse sentido, Freire (2001), é enfático em afirmar que o ensinar, nessa perspectiva, tem muitas exigências, dentre elas: 0 ensinar exige consciência do inacabamento, isso significa que o professor precisa entender-se como um permanente aprendiz; ensinar exige também respeito à autonomia do ser do educando e aos seus saberes e a disponibilidade ao diálogo e criticidade.

Um dos caminhos que se pode buscar no sentido de garantir a formação de um sujeito autônomo é a utilização de metodologias que tiram o aluno da zona de conforto, que o impulsiona a deixar de ser um agente receptivo e o coloca como um participante ativo nas situações de aprendizagem, tais metodologias "colocam o aluno diante de problemas e/ou desafios que mobilizam o seu potencial intelectual" (BERBEL, 2011, p. 34).

Pode-se destacar ainda que tais metodologias são processos que exigem interação, conhecimento, estudos, pesquisas individuais e/ou coletivas e por isso permitem a construção da autonomia do educando e contribuem para que o mesmo possa ler e compreender sua realidade e tenha condições de superar desafios.

Nesse sentido, Morán (2015, p. 17), afirma que "as metodologias precisam acompanhar os objetivos pretendidos. Se queremos que os alunos sejam proativos, precisamos adotar metodologias que os alunos se envolvam em atividades cada vez mais complexas, que tenham que tomar decisões e avaliar os resultados." Assim, se quisermos formar alunos para um mundo que exige o pensamento reflexivo, a capacidade de se reinventar, de aprender, desaprender e reaprender, quando necessário, e de compreender que a aprendizagem é contínua e exige a autonomia, temos que lançar mão de estratégias de ensino que nos deem estas possibilidades.

\subsection{JÚRI SIMULADO E DRAMATIZAÇÃO: POSSIBILIDADES DE SUPERAÇÃO DA EDUCAÇÃO BANCÁRIA}

Visando apontar possibilidades para a superação das práticas da educação bancária é que se propõe analisar duas estratégias de ensino em situações de aprendizagem nas quais os participantes se envolveram ativamente. As estratégias desenvolvidas e analisadas foram o Júri Simulado e a Dramatização e aconteceram numa formação continuada para estudantes de Pedagogia que atuam como estagiários nas creches da Rede Pública Municipal de Ensino de Imperatriz/MA.

Assim, compreendendo que o Júri Simulado "leva em consideração a possibilidade da realização de inúmeras operações de pensamento, como: defesa de ideias, argumentação, julgamento, tomada de decisão, etc." (ANASTASIOU E ALVES, 2003, p. 99). E tendo em vista que a temática a ser abordada neste encontro de formação seria: "As interações e as brincadeiras na educação infantil" e considerando ainda 
que o brincar muitas vezes é questionado, e por alguns mais tradicionais, até combatido, decidimos iniciar o estudo do tema com um "julgamento" do brincar na educação infantil.

Desse modo, ao iniciar o encontro foi solicitado que os estagiários observassem alguns brinquedos que estavam dispostos no ambiente e apontassem problemas ou possibilidades pedagógicas. Rapidamente surgiram comentários e houve uma breve "tempestade de ideias". Em seguida os participantes foram divididos em quatro grupos de estudos, sendo que dois grupos levantariam argumentos de defesa da ludicidade e do brinquedo na Educação Infantil, para tanto fundamentariam seus argumentos na experiência vivida e nas Diretrizes Curriculares Nacionais para a Educação Infantil; os outros dois grupos, com base em estudos que baseiam a Pedagogia Tradicional e também nas experiências vividas levantariam argumentos contrários.

Posteriormente ao estudo em grupo, houve os debates (arguição, réplica e tréplica) entre acusação e defesa que ocorreu de forma tranquila. Em seguida o "escrivão" apresentou o relatório à "juíza" que leu a síntese do que fora posto por cada grupo e solicitou ao "conselho de sentença" que respondesse à seguinte pergunta: Pelos argumentos expostos, vocês estão de acordo com a absolvição do réu - o brincar na Educação Infantil? Os membros do "conselho de sentença" decidiram pela absolvição do "réu". De um modo geral, a estratégia possibilitou ampla participação, oportunizando ainda que de modo interativo todos conhecessem os principais argumentos contrários e a favor sobre o brincar na educação infantil, permitindo então, o compartilhar das ideias e contribuindo para o desenvolvimento da capacidade de argumentar.

Participaram do referido encontro 65 estagiários, para os quais foi solicitado que avaliassem o encontro, 25 fizeram a avaliação, todos apontaram aspectos positivos, 05 também apontaram algum aspecto como negativo. A seguir algumas falas que podem ilustrar bem as percepções sobre a estratégia do Júri Simulado.

O Estagiário E1625 fez o seguinte comentário ao referir-se aos aspectos positivos: "aprendi e me diverti muito com o momento do júri". no mesmo tom o Estagiário E17 disse: "Rendeu momentos de muitas risadas, mas, não fugindo do foco". Este pensamento corrobora com Sampaio (2010), que afirma que dentre as formas de compreensão formativa está a capacidade de articular saberes disciplinares e saberes da vida, proporcionar alegria, sensibilidade, criatividade e beleza na formação. Assim, infere-se que a estratégia Júri Simulado pôde proporcionar aos participantes momentos de alegria e sensibilidade articulando os conteúdos aos saberes da vida.

Destaca-se ainda como positividade a possibilidade de refletir sobre determinado tema ou problema, a partir de leituras diferentes sobre uma mesma temática. Nesse sentido destaca-se a avaliação do estagiário E10, que considerou positiva a estratégia por possibilitar conhecer posições diferentes sobre um mesmo tema e considerou relevante "a fala (argumentos) de cada posição sobre o tema em estudo". Ainda neste mesmo sentido, o Estagiário E19 afirmou que a estratégia "foi importante para sabermos as diversas opiniões".

Nesse sentido, Anastasiou e Alves (2003, p. 84) afirmam que "participar de grupos de estudos permite o desenvolvimento de uma série de papeis que auxiliam na construção da autonomia (...) do lidar com o diferente, da exposição e da contradição, do divergir, do sintetizar (...)" assim, se percebe que também neste aspecto a estratégia Júri Simulado trouxe contribuições para a formação deste aluno autônomo que se deseja.

Em relação aos aspectos que foram apontados como negativos no desenvolvimento da estratégia, três estagiários falaram sobre a organização do tempo, pois consideraram o tempo destinado para a organização da estratégia insuficiente e dois ponderaram que os argumentos da acusação poderiam ter sido mais consistentes. Percebe-se, desse modo, que os aspectos negativos não se referiram diretamente à estrutura e forma da estratégia e sim ao tempo e ao conhecimento dos participantes sobre o tema em estudo. Talvez um possa levar ao outro, pois se houvesse mais tempo para organização e preparo provavelmente os argumentos poderiam ser mais consistentes. Todavia, de um modo geral, pode-se dizer que a estratégia Júri simulado foi bem aceita pelos participantes, promoveu o envolvimento da turma, permitiu a reflexão e a aprendizagem de ativa.

No mesmo contexto, de buscar superar a repetição e a memorização mecânica, a estratégia de Dramatização foi escolhida em razão de que ela "traz à sala de aula um pedaço da realidade social, de

25 Chamaremos de E1, E2, E3... os estagiários que participaram do primeiro encontro de formação que foi desenvolvida a estratégia Júri Simulado. 
forma viva e espontânea, para ser observada e analisada pelos estudantes" (ANASTASIOU; ALVES, 2003, p. 96). Considerando que a temática da aula era a Cultura Escrita na Educação Infantil, e que dentre os objetivos buscava se discutir e fundamentar a importância da leitura no contexto da Educação Infantil e refletir sobre o papel do professor na formação do leitor na Educação Infantil, é que se pensou em realizar dramatizações com o intuito de trazer para a sala de aula recortes da realidade vivida pelos estagiários nas instituições onde atuam.

Para servir de inspiração, antes da realização das dramatizações fez-se uma leitura em voz alta da história infantil intitulada: Quem tem medo de dragão? (JOLYE; ROCHUT, 2013). Após a referida leitura abriu-se um espaço que se comentassem sobre a mesma e assistiu-se a um vídeo que demonstrava a leitura da história por um menino de 03 anos de idade, onde se percebeu que é possível apresentar a cultura escrita às crianças bem pequenas. Logo após, fez-se uma exposição dialogada sobre a importância da cultura escrita nos primeiros anos de escolaridade, baseada nos estudos de Bresciane (2006), que afirma que logo nos primeiros meses de vida, as histórias já devem ser inseridas no cotidiano da vida infantil, pois ao ler ou contar histórias para os bebês e crianças pequenas, se permite a interação com o mundo da leitura e da escrita.

Após a situação de aprendizagem supracitada, que visava refletir sobre a importância da leitura na educação infantil e do papel do professor na formação do leitor na educação infantil e tendo já proporcionado aos participantes da formação um contato com o referencial teórico, se propôs aos estagiários a realização de dramatizações que retratassem a temática abordada. Participavam deste encontro de formação 45 estagiários que foram divididos em três equipes, cada equipe planejou, organizou e apresentou uma dramatização retratando uma situação de aprendizagem envolvendo a leitura de uma história infantil, o público que deveria ser representado era o de crianças de zero a três anos de idade. 0 momento das dramatizações foi rico e descontraído, os estagiários demonstraram tanto posturas apropriadas como inapropriadas para a realização da leitura e/ou contação da história e estas foram analisadas pelos demais grupos.

Assim como no encontro anterior, foi solicitado aos participantes, que avaliassem o encontro apontando aspectos positivos e negativos. Dos 45 participantes, 25 responderam a referida avaliação e sobre a realização da Dramatização não houve quem apontasse nenhum ponto negativo. A seguir algumas considerações importantes.

Alguns afirmaram que a estratégia Dramatização pode permitir o retrato, a reflexão e análise da realidade, destacam-se os seguintes posicionamentos: Estagiário E2.526 que disse que para ele a estratégia "Foi uma exposição da realidade da maioria. Foi muito proveitosa"; o estagiário E2.7 afirmou: "Foi maravilhoso trabalhar com a realidade que estamos vivendo"; o estagiário E2.4 disse que foi positiva a utilização da estratégia pois a mesma pode "trazer o que realmente acontece em sala de aula"; já o estagiário E2.25, afirmou que as dramatizações "permitiram refletir sobre a prática pedagógica".

Percebe-se nas falas supracitadas que a compreensão dos mesmos em relação à estratégia dramatização vai ao encontro do pensamento de Anastasiou e Alves (2003) que apontam como uma das características da referida metodologia a possibilidade que a mesma tem de trazer para a sala de aula parte da realidade vivida de forma espontânea e ainda permitir que a mesma seja analisada.

Outros destacaram como positivo, o fato de terem aprendido sobre os procedimentos adequados para a leitura de histórias na Educação Infantil. Nesse contexto, podemos destacar as seguintes respostas: Estagiário E2.22: "pudemos ver os erros constantes e os pontos positivos na hora do conto" e do estagiário E2.21: "pudemos aprender o que temos que fazer no momento de contar história". Assim, percebe-se que a estratégia Dramatização corrobora também com o que preceitua a metodologia ativa, pois permite o pensar, o refletir sobre situaç̃ões problemas do cotidiano, permitindo ao aluno e ao professor a superação de práticas bancárias de educação onde a repetição e a aprendizagem mecânica são valorizadas, entendese que "o aprendizado se dá a partir de problemas, situações reais; os mesmos que os alunos vivenciarão depois na vida profissional" (MORÁN, 2015, p. 19).

Percebeu-se nas duas estratégias que o desenvolvimento da atividade proposta contou com a participação ativa dos alunos, que o papel do professor não foi o de protagonista do processo, e sim o de mediador, o de desafiador, coube à equipe de formadora, o planejamento da situação de aprendizagem e o instigar da equipe para que os resultados fossem alcançados.

${ }^{26}$ Chamaremos de E2.1, E2.2, E2.3... os estagiários que participaram do segundo encontro de formação que foi desenvolvida a estratégia Dramatização. 
Pode-se dizer que as estratégias analisadas exigem um perfil de aluno ativo, que critica e se envolve na busca soluções. Quanto ao professor, ele deixa de ser o centro do processo, pois o aluno é desafiado a buscar a informação em outros espaços e a refletir e propor novas situações e não apenas a reproduzir as informações já postas.

\section{CONSIDERAÇÕES FINAIS}

Este texto aponta que no cenário educacional mudanças são necessárias para se romper com as práticas bancárias de educação. Mudanças essas, exigidas pela contemporaneidade e, dentre elas, as posturas autoritárias e centralizadoras de muitos professores. Para a promoção desta mudança ficou evidenciado que pode ser muito importante a adoção de metodologias que permitem a participação; que coloca o aluno diante de situações de desafios; que o instiga a pensar e refletir sobre suas práticas e sobre os conteúdos dados no currículo; metodologias que contribuam para formação de homens e mulheres proativos e que saibam se posicionar frente aos desafios diários; metodologias que valorizem o diálogo, enfim metodologias que colaborem com formação de homens e mulheres autônomos.

Pelo exposto, pode-se afirmar que, do ponto de vista dos estagiários, as estratégias apresentaram mais aspectos positivos do que negativos, percebeu-se pelas falas dos mesmos que houve participação e interação, que as mesmas puderam proporcionar momentos de reflexão sobre a realidade, de criticar, de analisar e de propor intervenções, trabalhando assim com conteúdos não dados, mas problematizados. Foi possível também trabalhar com conceitos, pois estes eram fundamentais para o desenvolvimento tanto dos argumentos sobre o brincar na educação infantil do Júri Simulado como para a composição e análise das Dramatizações sobre a cultura escrita.

Quanto às dificuldades encontradas pelos estagiários, apenas no júri simulado houve relatos de dificuldades e as mesmas dizem respeito à organização do tempo e da necessidade de maior embasamento para a realização do Júri Simulado. Desse modo percebe-se que para os estagiários, a superação das dificuldades pode se dar se houver maior tempo para a organização e estudos. Ressalta-se ainda que até os que apontaram pontos negativos perceberam na estratégia positividades que favorecem o uso da mesma quando se pretende envolver os alunos e possibilitar aos mesmos a análise critica dos conteúdos, a participação, o envolvimento.

Enquanto formadores, não encontramos dificuldades para a realização das situações de aprendizagem, ao contrário, foram momentos de muita interação e aprendizagem e que por isso foram prazerosos de se vivenciar. Enfim, nas situações de aprendizagem analisadas pôde-se sentir o envolvimento, o engajamento dos estagiários na busca de aprender para desenvolver bem suas atividades, refletindo sobre os desafios postos, argumentando, enfim, alunos/estagiários autônomos, reflexivos e ativos durante o processo de aprendizagem.

\section{REFERÊNCIAS}

[1] Anastasiou, Léa das Graças Camargos e Alves, Leonir Pessate (orgs.). Processos de Ensinagem na universidade: pressupostos para as estratégias do trabalho em aula. Joinvilie, SC: Editora Univille, 2003.

[2] Bauman, Zygmunt. Os desafios da educação: aprender a caminhar sobre areias movediças. Cadernos de Pesquisa, v.39, n.137, p.661-684, maio/ago. 2009. Entrevista concedida a Alba Porcheddu. Tradução Neide Luzia de Rezende e Marcello Bulgarelli.

[3] Berbel, Neusi Aparecida Navas. As metodologias ativas e a promoção da autonomia de estudantes. Semina: Ciências Sociais e Humanas, Londrina, v. 32, n. 1, p.25-40, jan./jun. 2011. Semestral.

[4] Freire, Paulo. Pedagogia da autonomia: saberes necessários à prática educativa. São Paulo: Paz e Terra, 2001.

[5] Jolye, Fanny; Rochut, Noel. Quem tem medo de Dragão?. Scipione. São Paulo. 2013

[6] Morán, José. Mudando a Educação com Metodologias Ativas. Coleção Mídias Contemporâneas. Convergência Midiáticas, Educação e Cidadania: aproximações jovens. Vol. II. P. 15-33. 2015. Disponível em: http://www2.eca.usp.br/moran/wp-content/uploads/2013/12/mudando_moran.pdf. Em 10 de maio de 2016.

[7] Sampaio, Ana Tânia Lopes. Pedagogia Vivencial Humanescente: complexidade e transdisciplinaridade para reencantar a educação. In: Conferência Internacional Sobre os Setes Saberes Para a Educação Presente. 2010, Fortaleza. Anais. Fortaleza: $\quad$ UECE, 2010. $\quad$ online. Disponível em: <http://www.uece.br/setesaberes/anais/pdfs/trabalhos/1098-07082010-222613.pdf>. Acesso em: 11 maio 2016. 


\section{Capítulo 19}

\section{Ficha catalográfica dinâmica como recurso educacional para cursos de biblioteconomia}

\section{Graciane Silva Bruzinga Borges \\ Letícia dos Santos Miranda \\ Mariana Freitas Canielo de Carvalho \\ Celsiane Aline Vieira Araújo \\ Benildes Coura Moreira dos Santos Maculan}

Resumo: A Ficha Catalográfica é um instrumento utilizado pelos bibliotecários para compilar dados bibliográficos (descritivos e temáticos) de recursos informacionais, tais como livros, para individualizá-los e facilitar a localização de assuntos e de documentos em acervos físicos em diferentes unidades de informação. Este trabalho tem como objetivo a concepção de uma Ficha Catalográfica Dinâmica como recurso educacional a ser utilizado em disciplinas do campo temático da Organização e Tratamento da Informação. Para isso, o referencial teórico foi elaborado com apontamentos sobre o curso de Biblioteconomia e os princípios gerais de seis disciplinas nesse campo temático: Fundamentos de Organização da Informação; Análise de Assunto; Linguagem de Indexação; Catalogação Descritiva; Classificação Decimal de Dewey e Classificação Decimal Universal, juntamente com os fundamentos e características da Ficha Catalográfica tradicional. A metodologia é composta de cinco fases: 1) planejamento; 2) execução; 3) operação; 4) manutenção; e 5) encerramento, e tem como base uma parceria com o curso de Sistemas de Informação da Universidade Federal de Minas Gerais e com o Centro de Apoio à Educação a Distância da mesma universidade. Os resultados parciais são positivos, e as ações futuras visam a melhorias quanto ao processo de ensino e aprendizagem sobre ordenação e formatação de dados bibliográficos.

Palavras-chave: Ficha Catalográfica Dinâmica; Ficha Catalográfica; Recurso Educacional; Organização e Tratamento da Informação; Biblioteconomia. 


\section{INTRODUÇÃO}

As fichas catalográficas tiveram início ainda em formato manuscrito e impresso e, na contemporaneidade, são registros bibliográficos legíveis por máquina, saindo "dos catálogos impressos para os catálogos em linha até as redes de catalogação cooperativa" (MACHADO; VON HELDE; COUTO, 2007, p. 101). Ademais, as fichas catalográficas também contêm, além dos pontos de acesso, a descrição bibliográfica e o número de chamada dos recursos informacionais de um acervo. A Ficha Catalográfica Dinâmica (FC-d) corresponde a um recurso educacional para uso nas disciplinas da área de Organização e Tratamento da Informação (OTI) do curso de Biblioteconomia da UFMG. Pretende-se inovar no processo de ensinoaprendizagem no ensino superior por meio de um recurso que irá simular uma ficha catalográfica tradicional.

A FC-d deverá possuir campos descritivos editáveis para preenchimento individual dos alunos, bem como possibilitar ao professor a manipulação dos dados inseridos a fim de viabilizar sua análise, correção e avaliação individualizada. Assim, faz-se necessário um minucioso planejamento do percurso metodológico a ser executado.

De maneira geral, o desenvolvimento da $\mathrm{FC}$-d está vinculado ao macroprojeto intitulado Estudos em Organização e Tratamento da Informação (EOTI), proposto pelo Grupo de Pesquisa em Representação do Conhecimento e Recuperação da Informação (RECRI), da Escola de Ciência da Informação (ECI), da Universidade Federal de Minas Gerais (UFMG). De maneira específica, o desenvolvimento do recurso está ligado ao "Subprojeto PIFD" - Programa de Incentivo à Formação Docente (PIFD), fomentado pela Próreitoria de Graduação (PROGRAD), que visa contribuir para a qualidade e melhoria do ensino nos cursos de graduação da UFMG.

Nesse sentido, o subprojeto prevê a modelagem de seis disciplinas do curso de Biblioteconomia em formato semipresencial, o que vem possibilitando aos bolsistas a obtenção de conhecimentos teóricos e práticos quanto às principais estratégias de ensino e ferramentas disponíveis para o Ensino a Distância EAD. Em 2017, firmou-se uma parceria com o Centro de Apoio à Educação a Distância (CAED) da UFMG com o intuito de apoio técnico pedagógico ao grupo durante o processo de produção de materiais didáticos para uso nas disciplinas contempladas no subprojeto.

Neste trabalho, apresenta-se a concepção da FC-d, com a sua elaboração e implementação como um dos recursos que vêm sendo construídos por meio da parceria com o CAED. Para tanto, após a introdução, o texto se organiza da seguinte maneira: na seção 2, expõe-se o referencial teórico que fundamenta a concepção da FC-d, abordando-se tanto o contexto do próprio curso de Biblioteconomia como o escopo das disciplinas da OTI, apresentando os principais conceitos, um breve histórico e as funções da ficha catalográfica; na seção 3, é apresentada a metodologia de elaboração da FC-d, estruturada nas seguintes fases: 1) planejamento; 2) execução; 3) operação; 4) manutenção e 5) encerramento; finalmente, na seção 4 , são apresentadas as análises e as considerações gerais do trabalho, bem como os resultados esperados.

\section{REFERENCIAL TEÓRICO}

O curso de Biblioteconomia está direcionado para a atuação na organização e gestão da informação em organizações públicas e privadas. Além disso, o profissional da área possui um vasto campo de atuação como profissional liberal, por meio de consultorias, na administração e no planejamento de unidades de informação e na elaboração de sistemas de informação. Para isso, é necessária a oferta de disciplinas que integrem os níveis teórico e prático para o entendimento da atuação profissional.

Dentre as disciplinas ofertadas pelos cursos de graduação, destacam-se seis, que formam a base teórica sobre a organização, o tratamento e a disseminação da informação, que são: Fundamentos de Organização da Informação, Análise de Assunto, Linguagem de Indexação, Catalogação Descritiva, Classificação Decimal de Dewey (CDD) e Classificação Decimal Universal (CDU). São disciplinas obrigatórias, que fundamentam o tratamento da informação e constituem as diretrizes do Grupo de pesquisa RECRI, que é formado pelos docentes das disciplinas correspondentes.

Cada disciplina apresenta aspectos importantes que levam à teorização do processo de tratamento que o bibliotecário deverá realizar para que a informação disponível em uma unidade de informação possa ser organizada, representada e recuperada, de forma a atender às necessidades do usuário. Nesse contexto, a ficha catalográfica corresponde a um importante recurso que contém os resultados compilados da atividade de processamento técnico de itens informacionais realizada pelo bibliotecário em acervos. 0 seu preenchimento perpassa os processos de indexação (análise de assunto e tradução) e de catalogação 
(principalmente, elementos descritivos), incluindo a classificação e um número de chamada para determinar uma localização individualizada dos itens que compõem um acervo.

\subsection{A FICHA CATALOGRÁFICA TRADICIONAL}

Em um Sistema de Recuperação da Informação (SRI), a catalogação é um dos processos técnicos realizados para o tratamento intelectual de um documento e seus objetivos são determinar suas características fundamentais de forma a distingui-lo de outros e apresentar esses dados em fichas catalográficas, que, por sua vez, são intercaladas em catálogos impressos de um SRI, e também são elementos de livros, teses e dissertações (CORRÊA, 2008).

A ficha catalográfica é usada desde 1775, e seu tamanho, $12,5 \times 7,5 \mathrm{~cm}$, foi padronizado no final do século XIX, após a impressão de fichas e sua posterior venda pela Library of Congress (Biblioteca do Congresso) dos Estados Unidos da América, em 1901 (CUNHA; CAVALCANTI, 2008). A ficha pode conter ou não um furo na parte inferior central. Em um catálogo de biblioteca, esse furo permite que ela seja inserida em uma vareta, o que impede a sua retirada da gaveta, de forma a preservar a forma em que foi colocada.

É um elemento obrigatório de teses e dissertações, segundo a NBR 14724/2005, e de livros. Segundo essa norma, a ficha é um elemento pré-textual, ou seja, "antecede o texto com informações que ajudam na identificação e utilização do trabalho" (ASSOCIAÇÃO BRASILEIRA DE NORMAS TÉCNICAS, 2002, p. 2). Deve ser impressa no verso da folha de rosto, na parte inferior da folha e com o tamanho padrão de $7,5 \mathrm{~cm}$ x 12,5 cm. No Brasil, o uso da ficha catalográfica foi regulamentado pela Política Nacional do Livro, no capítulo III da Lei n.o 10.753 de 30 de outubro de 2003 (BRASIL, 2003).

Na tecnologia de fichas manuscritas e impressas, as próprias fichas catalográficas formavam o catálogo impresso (físico) e eram condicionadas em arquivos metálicos para serem consultados pelos usuários em busca de algum assunto e/ou documentos de um acervo. Com isso, criava-se uma cópia da ficha catalográfica para cada tipo de ponto de acesso (em geral, autor, título, série e assunto). Nesses casos, para um livro com três autores, por exemplo, seriam criadas três fichas catalográficas, uma para cada autor, que seriam idênticas, a não ser pelo ponto de acesso em questão, diferença dos autores, que seria o ponto de acesso principal em uma das fichas, e, assim, as fichas também seriam diferentes no que se refere aos pontos de acesso secundários. Com isso, cria-se uma lista organizada e ordenada de registros dos documentos de um acervo, na qual se torna possível recuperar os documentos que foram tratados sem que seja preciso acessá-los fisicamente.

Nos dias atuais, os registros das fichas catalográficas são armazenados em computadores e bases de dados e formam os catálogos on-line. Nesse contexto, as fichas podem ser feitas apenas uma vez, gerando, automaticamente, diferentes entradas, o que veio facilitar as atividades biblioteconômicas. $\mathrm{Na}$ contemporaneidade, a catalogação é realizada a partir de programas como o Biblio.BASE, o Docbase, o Millenium, entre outros, sendo que as regras de catalogação são as mesmas, assim como a aparência final do registro apresentado é basicamente igual ao de uma ficha catalográfica manual.

\subsubsection{ELEMENTOS DA FICHA CATALOGRÁFICA}

A elaboração de fichas catalográficas é orientada por códigos de catalogação, como o Anglo American Cataloging Rules - AACR2, que é o instrumento mais fiel aos princípios estabelecidos na Conferência de Paris (1961), e o mais aceito internacionalmente. Com a necessidade de compartilhamento das fichas, foi criada, em 1971, a International Standard Bibliographic Description (ISBD), com o objetivo de padronizar a catalogação descritiva e orientar a ordenação e as pontuações que são inseridas antes de cada informação, de modo a tornar possível seu reconhecimento por softwares computacionais. Esse tipo de padronização tem a vantagem de permitir a interpretação dos dados bibliográficos para além dos limites da barreira linguística. Esses dois códigos se complementam, uma vez que cada informação registrada na ficha catalográfica definida pelo ISBD como estrutura de zonas foi incorporada pelo AACR2 com o nome de áreas. Contudo, são instrumentos independentes.

Conforme o AACR2, as informações contidas na ficha são divididas nas seguintes áreas: 1) entrada principal ou ponto de acesso principal; 2) área do título e indicação de responsabilidade; 3) área da edição; 4) área da publicação; 5) área da descrição física; 6) área da série; 7) área das notas; 8) área do número normalizado e 9) área dos pontos de acesso secundários. Além dessas áreas, também é incluído o número de chamada. Todos esses elementos são apresentados na Figura 1. 
FIGURA 1 - Elementos da ficha catalográfica tradicional:

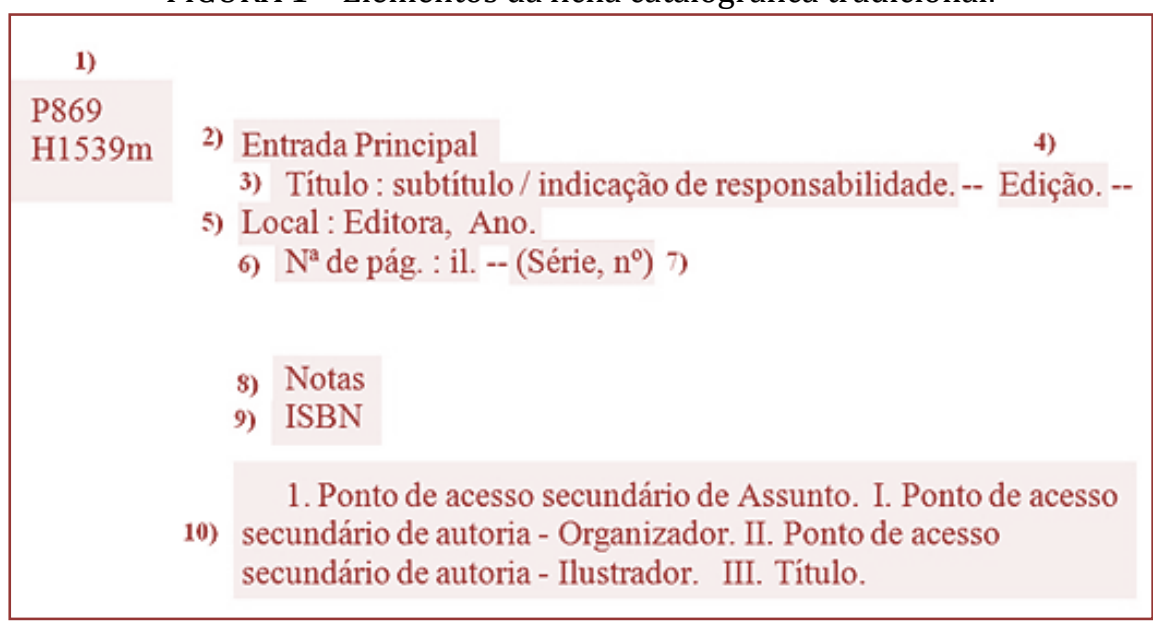

1. Número de chamada

2. Entrada principal ou ponto de acesso principal

3. Área do título e indicação de responsabilidade

4. Área da edição

5. Área da publicação

6. Área da descrição física

7. Área da série

8. Área de notas

9. Área do número normalizado

10. Área dos pontos de acesso secundários

Fonte: elaborada pelas autoras.

O número de chamada, representado pelo número 1, é constituído pelos seguintes elementos: a notação de autor e o número de classificação. A notação de autor é criada usando-se a Tabela Cutter-Sanborn (1880) ou a Tabela PHA (2000). Já o número de classificação é criado a partir de um Sistema de Classificação Bibliográfica, sendo os mais utilizados a Classificação Decimal de Dewey (CDD) e a Classificação Decimal Universal (CDU).

$\mathrm{Na}$ área da entrada principal ou ponto de acesso principal, número 2, é registrado o nome de um autor ou de um título, para a identificação de um item bibliográfico. A área do título e indicação de responsabilidade, número 3 , traz o registro do título da obra e os responsáveis pelo conteúdo intelectual e artístico do documento, ou seja, seus autores.

O número 4 traz a área da edição. A indicação compreende um número seguido da palavra edição de forma abreviada. Na área da publicação, número 5, é escrito o local de publicação do documento, a editora e sua data de publicação. Na área da descrição física, número 6, está registrada a extensão do documento (número de páginas), se o material é ilustrativo (uso da sigla il.) e o tamanho do documento em centímetros. A área da série, 7, é usada quando o documento pertence a alguma série ou coleção.

$\mathrm{Na}$ área das notas, representada pelo número 8, estão informações úteis que são acrescentadas pelo Bibliotecário catalogador, mas que não têm lugar no corpo da descrição. 0 número 9 traz a área do número normalizado, ou seja, o ISBN (International Standard Book Number). O ISBN é um sistema que identifica numericamente determinado item com exclusividade. E, por fim, o número 10 representa a área dos pontos de acesso secundários. Esses pontos de acesso, também conhecidos por pistas, são um roteiro das fichas secundárias, a serem desdobradas para representar a publicação nos catálogos. Nessa área são registrados os pontos de acesso de assunto, de autoria e de título do documento. 
Cada área da ficha é elaborada e estudada usando-se os aportes teóricos das seis disciplinas de OTI, iniciando pela inclusão da essência do conteúdo de um dado documento advinda da atividade de análise de assunto, até a inserção dos códigos e notações resultantes do processo de indexação, obtidos por meio do uso das linguagens de indexação artificiais e que servirão para localização física da obra nas estantes de um dado acervo. Além desses, a ficha contempla a inclusão dos metadados referentes à descrição física do item, proveniente da atividade de catalogação descritiva, como exemplos, os campos destinados à identificação do título e autor.

\section{METODOLOGIA}

A metodologia de construção da FC-d está pautada no estabelecimento de uma parceria com alunos do curso de Sistemas de Informação da UFMG matriculados na disciplina de Organização e Tratamento da Informação (OTI). Tal disciplina é ofertada sob a responsabilidade do Departamento de Organização e Tratamento da Informação (DOTI) do curso de Biblioteconomia da mesma universidade. Essa parceria tem o intuito de praticar a multidisciplinaridade entre as áreas que fazem interface com a Biblioteconomia, sendo que sua concretização dar-se-á por meio do Trabalho Final da disciplina, no qual os estudantes devem buscar um problema informacional da realidade, que, neste caso, é a elaboração da FC-d, para que os próprios alunos ofereçam uma solução voltada para a área de organização da informação.

Quanto ao aspecto teórico, previamente à definição da problemática, será realizada pesquisa bibliográfica para levantamento, seleção e validação dos melhores formatos de fichas a serem considerados para construção do objeto. Já no que diz respeito ao aspecto prático, será realizada pesquisa de recursos digitais disponíveis no mercado de software que sejam compatíveis com o Ambiente Virtual de Aprendizagem do CAED e, por consequência, compatíveis também com o ambiente Moodle da UFMG. Sendo assim, apresenta-se o percurso metodológico a ser realizado em conjunto com os alunos do curso de Sistemas de Informação.

\subsection{FASE 1 - PLANEJAMENTO}

\subsubsection{PRIMEIRA ETAPA: ESPECIFICAÇÃO DA DEMANDA}

Passo 1 - definir a problemática: fórum de debates entre alunos de Sistemas de Informação, bolsistas PIFD e professoras do RECRI a fim de elucidar as necessidades didáticas vinculadas à FC-d e especificar as funcionalidades desejáveis.

Passo 2 - construir planos de ação: elaboração dos Planos de Ação (PA) por parte dos grupos de alunos de Sistemas de Informação como esboços iniciais das propostas de soluções. Todos os PAs apresentados deverão conter, na perspectiva dos integrantes de cada grupo, os seguintes tópicos: 1) especificação do problema; 2) objetivo da solução; 3) metodologia proposta; 4) agentes envolvidos; 5) cronograma de execução; e 6) recursos necessários para desenvolvimento do trabalho.

Passo 3 - elaborar parecer técnico: validação e/ou solicitação de ajustes dos PAs apresentados pelos alunos de Sistemas de Informação por meio de um Parecer Técnico (PT). Os PTs serão elaborados pelas professoras do RECRI, em conjunto com os bolsistas do Subprojeto PIFD.

\subsubsection{SEGUNDA ETAPA: DESENHO DA SOLUÇÃO}

Passo 1 - prototipar a concepção: as soluções propostas pelos alunos dos Sistemas da Informação, a partir dos PAs aprovados, deverão contemplar os seguintes tópicos: 1) escopo do projeto; 2) não escopo do projeto; 3) objetivo geral; 4) processo de execução; 5) resultados esperados; 6) cronograma macro; 7) equipe necessária; e 8) premissas e restrições.

Passo 2 - modelar: disposição gráfica do desenho da solução para apresentação na etapa seguinte.

\subsubsection{TERCEIRA ETAPA: VALIDAÇÃO DA SOLUÇÃO}

Passo 1 - preparar apresentação: agendamento e viabilização de recursos para apresentação das propostas de solução.

Passo 2 - realizar seminário: apresentação das propostas em formato de seminário presencial. 


\subsection{FASE 2 - EXECUÇÃo}

\subsubsection{ETAPA ÚNICA: ELABORAÇÃO}

Passo 1 - escolher a solução: definição da(s) solução(ões) mais viável(is) para elaboração por parte dos bolsistas do Subprojeto PIFD, considerando a viabilização dos insumos.

Passo 2 - definir elementos de Arquitetura da Informação (AI): determinação dos instrumentos de gestão necessários e dos artefatos referentes às especificidades tecnológicas.

Passo 3 - testar a AI: preparação do ambiente de teste em parceria com a equipe de diagramação do CAED e realização dos ajustes de interoperabilidade que se fizerem necessários.

\subsection{FASE 3 - OPERAÇÃO}

\subsubsection{ETAPA ÚNICA: IMPLEMENTAÇÃO}

Passo 1 - capacitar equipe: repasse de conhecimento e orientação de uso a ser realizado pelos alunos de Sistemas de Informação e pelos bolsistas PIFD às professoras do RECRI.

Passo 2 - realizar operação assistida: acompanhamento programado de uso do recurso a fim de sanar possíveis dúvidas em tempo real.

\subsection{FASE 4 - MANUTENÇÃO}

\subsubsection{PRIMEIRA ETAPA: ATUALIZAÇÃO}

Passo 1 - atualizar instrumentos de gestão: revisão e atualização dos instrumentos de gestão da AI.

Passo 2 - atualizar os itens de tecnologia: revisão e atualização dos artefatos referentes às especificidades tecnológicas da AI.

\subsubsection{SEGUNDA ETAPA: MELHORIA}

Passo 1 - realizar assistência programada: prestação de assistência técnica programada de uso do recurso a fim de verificar sua efetividade no ambiente Moodle.

Passo 2 - debater as lições aprendidas: promoção de encontro entre os envolvidos no projeto a fim de refletir os erros e acertos do processo e propor-lhe melhorias.

\subsection{FASE 5 - ENCERRAMENTO}

\subsubsection{PRIMEIRA ETAPA: ANÁLISE ANTES \& DEPOIS}

Passo único - realizar reunião de encerramento de projeto: promoção de encontro entre os envolvidos no projeto a fim de analisar o processo como um todo e refletir sobre possibilidades de continuidade e ações futuras.

\subsubsection{SEGUNDA ETAPA: ATESTADOS}

Passo único - emitir certificados de capacitação: providenciamento de certificados de capacitação específicos para todos os envolvidos no processo.

\section{ANÁLISE E CONSIDERAÇõES}

\subsection{A FICHA CATALOGRÁFICA DINÂMICA NO SUBPROJETO PIFD}

O trabalho apresentou uma proposição metodológica para concepção e implementação de um recurso dinâmico, visualmente semelhante a uma Ficha Catalográfica tradicional, porém, com campos editáveis. Constatou-se que este recurso servirá de base para exercícios práticos em disciplinas da área de OTI. Na contemporaneidade, as fichas catalográficas são armazenadas, em sua maioria, em computadores, 
auxiliando bibliotecários e editores, por exemplo, na manutenção dos catálogos de bibliotecas ou unidades de informação. 0 uso de normas e códigos internacionais permite a padronização da catalogação em bases de dados e facilita o controle bibliográfico de um país.

\subsection{RESULTADOS ESPERADOS}

A concepção da FC-d tem como objetivo dinamizar o processo de ensino da elaboração da ficha catalográfica, que irá auxiliar o aprendizado da ordenação e formatação dos dados bibliográficos, em conformidade com as normas da Associação Brasileira de Normas Técnicas (ABNT) e do Código de Catalogação Anglo-Americano (AACR2), assim como a notação indicativa do autor, conforme a Tabela de Cutter-Sanborn.

Além disso, acredita-se que será possível alinhar o recurso para gerar uma classificação geral de assunto da obra, a partir da Classificação Decimal de Dewey (CDD) e da Classificação Decimal Universal (CDU), que são os dois sistemas de classificação bibliográfico ensinados no curso de Biblioteconomia.

No que tange à concepção de EAD, na qual se insere o escopo do Subprojeto PIFD e o processo de reconfiguração das disciplinas de OTI, pretende-se incentivar o formato híbrido (EAD e presencial) para o processo de ensino e aprendizagem da ficha catalográfica. Tal processo dar-se-á por meio da realização de exercícios de preenchimento da FC-d no ambiente Moodle permitindo a colaboração, já que a ficha terá campos editáveis e melhor apreensão da prática de catalogação no contexto prático colaborativo. Nesse sentido, o recurso didático de seminário, previsto para a fase de validação da solução poderá também ser considerado para compartilhamento de experiências entre alunos e professores.

\section{REFERÊNCIAS}

[1] Almeida, Neilia B. F. de; Baptista, Sofia G. Breve histórico da Biblioteconomia brasileira: formação do profissional. In: XXV Congresso Brasileiro de Biblioteconomia, Documento e Ciência da Informação, 2013, Florianópolis, SC. Anais... do Congresso Brasileiro de Biblioteconomia , Documentação e Ciência da Informação. Florianópolis,SC, 2013. 13 p. Disponível em: <https://anaiscbbd.emnuvens.com.br/anais/article/view/1508/1509> . Acesso em: 19 Jul 2018.

[2] Associação Brasileira de Normas Técnicas. NBR 14274: Informação e Documentação: Trabalhos acadêmicos: apresentação. Rio de Janeiro, 7 p. 2002.

[3] Brasil. Lei no 10.753, de 30 de outubro de 2003. Institui a Política Nacional do Livro. Diário Oficial [da] Imprensa Nacional, Brasília, DF, $30 \quad$ out. 2003 Disponível em: <http://www.planalto.gov.br/CCivil_03/leis/2003/L10.753.htm>. Acesso em: 29 jul. 2018.

[4] Corrêa, Rosa Maria Rodrigues. Catalogação descritiva no século XXI: um estudo sobre o RDA. 2008. 65f. Dissertação (mestrado) - Programa de Pós-graduação em Ciência da Informação, Faculdade de Filosofia e Ciências, da Universidade Estadual Paulista, Marília, 2008.

[5] Cunha, Murilo Bastos da; Cavalcanti, Cordélia Robalinho de Oliveira. Dicionário de Biblioteconomia e Arquivologia. Brasília, DF: Briquet de Lemos / Livros, 2008.

[6] Machado, E. C.; Von Helde, R. R.; Couto, S. D. Ensino de catalogação: da teoria à prática. Revista Brasileira de Biblioteconomia e Documentação, Nova Série, São Paulo, v. 3, n. 2, p. 100-106, jul./dez. 2007.

[7] Marconi, Marina de A.; Lakatos, Eva M. Fundamentos de metodologia científica. 7. ed. São Paulo: Atlas, 2010. 


\section{Capítulo 20}

\section{Acessibilidade digital: Um estudo acerca da acessibilidade, usabilidade e comunicabilidade em portais institucionais federais}

\section{Mariano Castro Neto \\ Leonardo Rodrigues de Almeida}

Resumo: Apresenta-se neste artigo uma pesquisa realizada acerca de acessibilidade digital, usabilidade e comunicabilidade em portais institucionais federais. Trata-se de uma pesquisa aplicada. Utililizaram-se avaliadores automáticos de acessibilidade em 6 (seis) portais a partir dos critérios e das recomendações do Web Content Accessibility Guidelines 2.0 (WCAG 2.0) e do Modelo de Acessibilidade do Governo Eletrônico (eMAG). Os resultados mostram problemas imagéticos, multimídia, links, dentre outros. Como continuação deste estudo, procurer-se-á ampliar as discussões acerca de critérios e requisitos utilizados pelos avaliadores automáticos de acessibilidade e discutir a construção de novos requisitos para avaliadores automáticos. 


\section{INTRODUÇÃO}

De acordo com Junior e Almeida (2009), a internet tem se mostrado uma ferramenta poderosa para execução de diversas ações do dia a dia. Com isso, segundo Freire (2008), "a globalização do acesso a informações requer uma atenção especial nos projetos de aplicações Web, que se depara com o desafio de atender a diferentes necessidades e restrições dos usuários".

No processo de interação, o usuário emprega um conjunto de fatores como: sua habilidade motora, seus sentidos, sua capacidade de percepção e sua capacidade cognitiva de interpretação e de raciocínio para compreender as respostas do sistema. A interface não poderá impor problemas ao usuário, caso contrário, a interação é prejudicada (BARBOSA, 2010).

É nesse contexto que o termo "acessibilidade" surge. A definição de acessibilidade para a Organização Internacional de Padrões (ISO) aproxima-se de usabilidade (FREIRE, 2012), levando em consideração a extensão dos aspectos da usabilidade a pessoas com deficiência. De acordo com a ISO 9241 padrão em Ergonomia de Sistema de Interação-Humana, parte-11 (International Standards Organization, 1998), a usabilidade é definida como "a medida em que um produto [serviço ou ambiente] pode ser usado por usuários específicos para alcançar objetivos específicos com efetividade, eficiência e satisfação em um contexto de uso especificado."

O W3C é uma referência mundial na definição de tais padrões, uma vez que incentiva o uso de tecnologias e linguagens não proprietárias, de código aberto. As recomendações lançadas pelo W3C pretendem, segundo a sua própria definição, fazer com que os benefícios de compartilhamento de comunicação, de informações e de comércio sejam disponíveis para todos, independentemente de equipamentos, dispositivos ou plataformas (RIBEIRO, 2006).

No Brasil, o primeiro passo para tornar os conteúdos disponíveis na Internet mais acessíveis ocorreu a partir do Decreto 5.296, de 02 de dezembro de 2004 (BRASIL, 2004), que regulamenta as Leis 10.098/00 e 10.048/00. Tal decreto, em seu artigo 47, torna obrigatória a acessibilidade nos sites da administração pública para pessoas com necessidades especiais, garantindo-lhes o pleno acesso às informações disponíveis. Esse decreto torna obrigatório que as entidades governamentais busquem maneiras de acessibilizar o conteúdo web de forma padronizada e o mais rápido possível.

Em dezembro de 2005, o Governo Federal, através do Ministério do Planejamento, Orçamento e Gestão, criou uma cartilha para auxiliar os desenvolvedores web a acessibilizar o conteúdo dos sites governamentais. Essa cartilha foi chamada de eMAG ou Modelo de Acessibilidade do Governo Eletrônico, consistindo na principal iniciativa em prol da acessibilidade virtual no Brasil.

\section{ACESSIBILIDADE}

0 conceito de acessibilidade que, originalmente, referia-se à Arquitetura e ao Urbanismo, vem sendo associado, segundo Queiroz (2006), como proveniente ou derivado da palavra acesso. No entanto, a acessibilidade contextualizada como conceito técnico ou prático normalmente faz referência às pessoas com deficiência. A aplicação do termo teve origem na necessidade de transposição de obstáculos arquitetônicos que impediam e impedem o acesso de pessoas deficientes a lugares públicos e de uso comum.

Por outro lado, Trentin (2007) ressalta que a acessibilidade não deve ser associada apenas às necessidades de pessoas com deficiência e sim a todas as pessoas com qualquer tipo de limitação temporária ou permanente. Queiroz (2006) afirma que essa dimensão da acessibilidade tem se tornado mais ampla ao longo do tempo e exemplifica com as calçadas esburacadas que se tornam perigosas para as mulheres grávidas que não conseguem enxergar os pés. Nesse caso, a gravidez não é reconhecida como deficiência, mas as calçadas não são adequadas para as mulheres grávidas como também não são para os deficientes. Dessa forma, a "acessibilidade diz respeito à qualidade ou falta de qualidade de vida para todas as pessoas" (QUEIROZ, 2006).

\subsection{ACESSIBILIDADE DIGITAL E NA WEB}

Apesar de indubitavelmente importante, a acessibilidade digital e na Web não é tão simples. As pessoas com deficiências possuem limitações sensoriais e motoras, que devem ser compensadas de alguma forma, a fim de viabilizar o acesso dessas pessoas aos recursos computacionais e, para isso, as organizações necessitam adaptar seu hardware e seus sistemas, a fim de fazer com que um computador possa ser usado 
por pessoas com deficiências (HARRISON, 2005). O problema é que essa adaptação requer um conhecimento técnico e pessoas especializadas, o que faz, muitas vezes, com que organizações não dediquem os esforços necessários ao processo de acessibilidade (TANGARIFE, 2005).

A definição de "acessibilidade na Web", termo usado neste trabalho, é adaptada a partir das definições da ISO 9241-11 (International Standards Organization, 1998) e ISO 9241-171 (International Standards Organization, 2008), e utilizada por Petrie (2009) como: "A medida em que um produto / site pode ser usado por usuários específicos com deficiência específica para alcançar objetivos específicos com efetividade, eficiência e satisfação em um contexto específico de uso"

As discussões acerca de acessibilidade, de acordo com Conforto e Santarosa (2002), estão relacionadas às limitações físicas ou sensoriais dos usuários com deficiência. Mas esses aspectos podem trazer benefícios a um número bem maior de usuários, permitindo que os conhecimentos disponibilizados na Web possam estar acessíveis a uma extensão muito maior, sem com isso prejudicar suas características gráficas ou funcionais. Segundo Barbosa (2010), isso significa que o sistema não deve ser desenvolvido de forma a atender apenas a uma classe especial de usuários.

\subsection{OS AVALIADORES DE ACESSIBILIDADE}

O Decreto no 5.296 , publicado em dezembro de 2004, torna obrigatória a acessibilidade nos portais e sites eletrônicos da administração pública na rede mundial de computadores para o uso das pessoas com deficiência, garantindo-lhes o pleno acesso aos conteúdos disponíveis.

O MAG 3.1 é um avaliador de acessibilidade em site. A versão 3.1, lançada em abril de 2014, foi desenvolvida por meio da parceria entre o Departamento de Governo Eletrônico da Secretaria de Logística e Tecnologia da Informação (SLTI) do Ministério do Planejamento e o Instituto Federal do Rio Grande do Sul (IFRS). Esta versão apresenta diversas melhorias no conteúdo do texto e, para torná-lo mais intuitivo e acessível, foram inseridos novos exemplos, inclusive com o uso de HTML5 e WAI-ARIA para determinadas recomendações (e-MAG, 2014).

Na elaboração do documento-proposta, foram consideradas as contribuições de especialistas e as novas pesquisas na área de acessibilidade à $W e b$, bem como as Recomendações de Acessibilidade para Conteúdo Web (WCAG) 2.0, da W3C, sempre com foco nas necessidades locais, visando atender as prioridades brasileiras. Por esta razão, para esta pesquisa, é importante a utilização deste avaliador de acessibilidade.

Já o avaliador de acessibilidade WCAG 2.0 a partir de Recomendações de Acessibilidade para o Conteúdo da Web, na sua segunda versão, foi publicado como uma Recomendação W3C, em dezembro de 2008, e define um conjunto de recomendações acerca de como tornar o conteúdo da Web mais acessível. A acessibilidade pressupõe desenvolver sites para vários tipos de usuários e que abranjam o maior número de pessoas com deficiência. Essas recomendações também se destinam às pessoas idosas, as quais adquirem algumas deficiências devido ao processo de declínio biológico, e assim possibilitar que o conteúdo Web fique mais acessível pelos usuários de uma forma em geral (WCAG 2.0,2008).

As WCAG 2.0 possuem dois objetivos principais: o $1^{\circ}$ refere-se à ideia de ser aplicado atualmente e futuramente em diferentes tecnologias $W e b$, a partir do W3C e de outras fontes. $02^{\circ}$ objetivo é a capacidade de ser testável através das avaliações realizadas por seres humanos, e um subconjunto das recomendações por testes automáticos (ALONSO et. al., 2010). Tendo em vista o atendimento de todo o universo de pessoas que as usam, as WCAG possuem vários níveis de abordagem, dentre eles cito como exemplos: os princípios (perceptível, operável, compreensível e robusto) que compõem a base para a fundação da acessibilidade Web; as recomendações que auxiliam os autores a entender os critérios de sucesso e a implementar as técnicas; os critérios de sucesso os quais permitem que as WCAG 2.0 sejam utilizadas em testes de conformidade. Existem três níveis de conformidade: A (o mais baixo), AA e AAA (o mais elevado), dentre outros.

\section{APLICAÇÃO DAS FERRAMENTAS}

A partir da URL da página, a ferramenta TAW faz a avaliação de acessibilidade segundo as regras WCAG 1.0 ou WCAG 2.0, além de fornecer as opções de nível A, AA ou AAA e as opções de tecnologias suportadas como o HTML, CSS e Javascript para que o usuário possa escolher (Figura 1). 
Figura 1 - Ferramenta automática TAW.

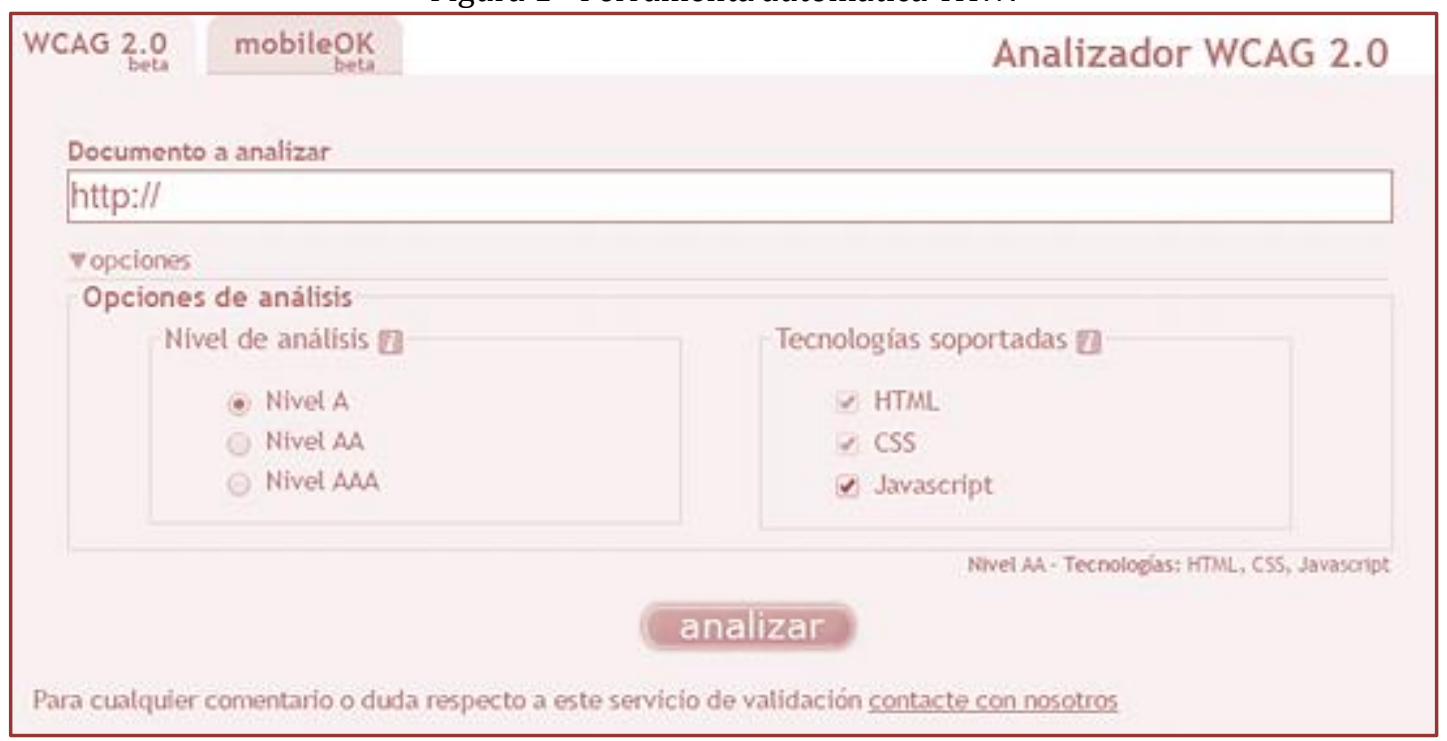

Ao inserir a URL e assinalar as opções, a ferramenta gera quatro tipos de relatórios: o relatório resumo, o marcado, o detalhado e a lista de problemas. Dentre eles, o usado para a avaliação automática foi o relatório detalhado que apresenta a quantidade de problemas, advertências e não verificados em cada um dos critérios de sucesso das WCAG. Apresenta também o número das linhas de código no qual os problemas ocorrem e fornece o código com as marcações dos problemas, advertências e não verificados.

\section{TRABALHOS RELACIONADOS}

Um estudo realizado no Departamento de Computação Aplicada, na Universidade de Dundee (http://www.dundee.ac.uk/), realizou uma auditoria de acessibilidade em 11 websites que fornecem informações e serviços ao setor de Ensino Superior do Reino Unido. Cada um desses onze sites é hospedado em uma instituição acadêmica da Comunidade de Ensino Superior do Reino Unido. Nesses estudos, realizaram-se avaliações automáticas utilizando as ferramentas: Bobby e $W 3 C$, além da avaliação manual. Os resultados mostraram que o nível global de acessibilidade dos sites era razoável. Detalhe: todos os sites avaliados apresentaram problemas de acessibilidade (SLOAN et. al., 2007).

Outro estudo foi realizado para analisar a acessibilidade de páginas Web de 162 Universidades do Reino Unido. Ao analisar os critérios WCAG 1.0 de prioridades 1 e 2, foi apontado que apenas 4 sites de Universidades atingiram o nível AA por não possuírem problemas de prioridade 1 e 2 . Entre elas estavam Universidade de Bristol, Universidade de East London, Universidade de Sheffield e Faculdade Writtle. A maioria dos sites pesquisados apresentam problemas de acessibilidade, menos da metade das páginas avaliadas violam a prioridade 1. Os principais problemas encontrados foram: a ausência de texto alternativo e a impossibilidade de redimensionamento das páginas. A pesquisa realizou apenas a avaliação automática e demonstrou a necessidade de realização de testes manuais, e, contudo, deixou claro que existe um longo esforço no trabalho de tornar os sites acessíveis (KELLY, 2002).

Na Universidade Federal de Lavras - portal UFLA (http://www.ufla.br/portal/), buscou-se analisar e avaliar a acessibilidade Web do referido portal. Os resultados desse estudo evidenciaram que foi um site concebido, desenvolvido, implementado a partir de recomendações/contribuições, inclusive para a acessibilidade de pessoas com deficiência. As avaliações realizadas pelos avaliadores automáticos de acessibilidade no site da UFLA mostram um bom padrão de qualidade, entretanto essas avaliações automáticas serviram como um bom aprendizado, confirmando as limitações da avaliação automática, sugerindo monitoramento da acessibilidade nos sites das instituições e inclusão de testes manuais, além de avaliações automáticas (RODRIGUES SOUZA, 2013). 
Também se realizaram pesquisas acerca de trabalhos relacionados à Avaliação da Acessibilidade web em portais de Instituições de Ensino Superior utilizando o Método Automático de Avaliação, apresentados no CBIE nas edições de 2013/2014/2015. De um modo geral, os trabalhos selecionados tratam de estudos pontuais. No caso específico deste, também se realizaram pesquisas acerca de trabalhos relacionados à Avaliação da Acessibilidade web nos portais de Instituições de Ensino Superior utilizando o Método Automático de Avaliação.

Entretanto, esses estudos evidenciam a importância e o avanço das pesquisas nessa área. Há um longo caminho a ser percorrido e, como forma de contribuir para o debate, este artigo se dedica a discorrer sobre a Avaliação de Acessibilidade web nos Instituições Federais de Ensino Superior utilizando o Método Automático de Avaliação a fim de discutir as dificuldades e benefícios encontrados na utilização desse método, bem como deixar uma proposta com recomendações que possibilitem aos desenvolvedores Web avaliar a acessibilidade de seu site.

\section{DISCUSSÕES}

A avaliação automática das 9 (nove) páginas principais dos portais da IFES, utilizando a ferramenta automática TAW, mostrou que todas as páginas (100\% das páginas) violaram o nível A que é o nível mínimo de conformidade e também violaram o nível AA e consequentemente o AAA. Com isso, a avaliação realizada mostrou que nenhuma das páginas analisadas está em conformidade com as WCAG 2.0.

Cada um dos tipos de problemas mais críticos encontrados na pesquisa será descrito no decorrer deste item. A partir da identificação e descrição de problemas, também serão fornecidas recomendações para melhoria e adequação do conteúdo de forma a torná-lo mais acessível.

Segundo as recomendações WCAG 2.0, se a página Web apresenta uma imagem que contém informações essenciais para a compreensão de um determinado conteúdo, esta deve apresentar texto alternativo (informado por meio do atributo alt), que transmita o mesmo significado da imagem e possibilite que o leitor de tela, ao focar na mesma, consiga ler o conteúdo e repassá-lo às pessoas com deficiências visuais.

0 portal da Universidade Federal da Paraíba (UFPB) não apresenta textos alternativos em imagens informativas de algumas páginas (Figura 3), é mostrada a ausência do atributo alt em imagens importantes no conteúdo da página inicial do Portal. Logo, para corrigir este problema, basta no código HTML, junto ao atributo img colocar um atributo alt especificando o significado da imagem.

Figura 2 - Ausência de texto alternativo nas imagens.

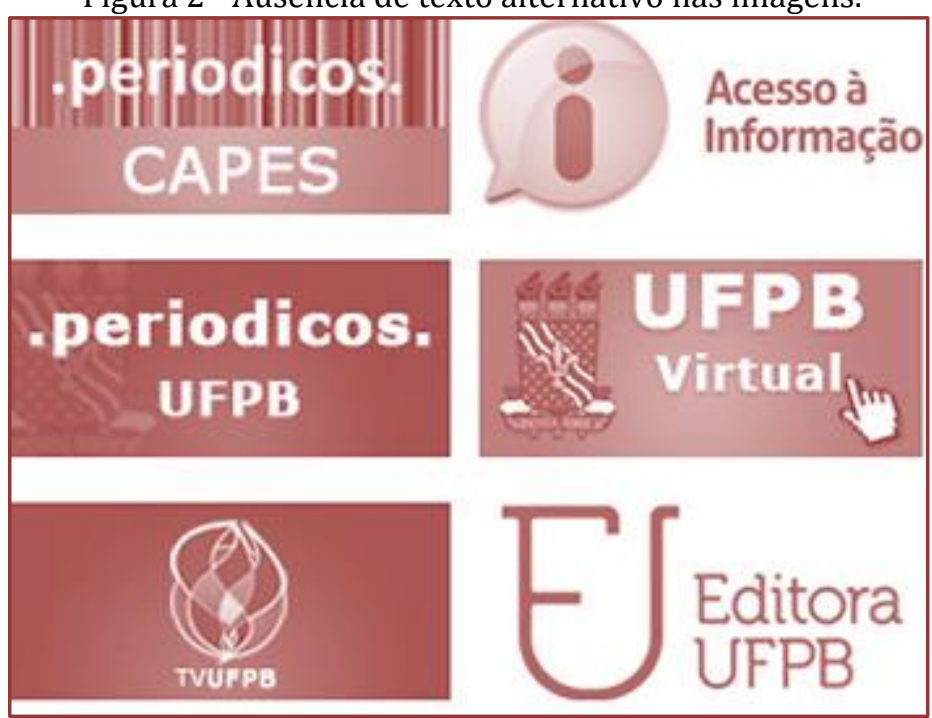


As WCAG 2.0 determinam que é necessário disponibilizar as informações transmitidas por meio do conteúdo de áudio e de vídeo a todos os usuários. Para que isso seja possível, todos os conteúdos de áudio e vídeo devem apresentar legendas e interpretação em língua de sinais, que permitem às pessoas surdas ou com dificuldades de audição a compreenderem o conteúdo.

Os portais da IFES analisados violam esses critérios de sucesso, uma vez que não apresentam legendas e nem a interpretação em língua de sinais para vídeos disponibilizados, como mostra a Figura 3. Para que esse problema seja solucionado, faz-se necessário que todos os conteúdos de vídeo apresentem alternativa em texto na forma de legenda, e que, por possuírem áudio, apresentem interpretação em Língua Brasileira de Sinais (LIBRAS) com um intérprete de língua de sinais ao canto do vídeo.

Figura 3 - Vídeo de notícias da TV Universitária em execução.

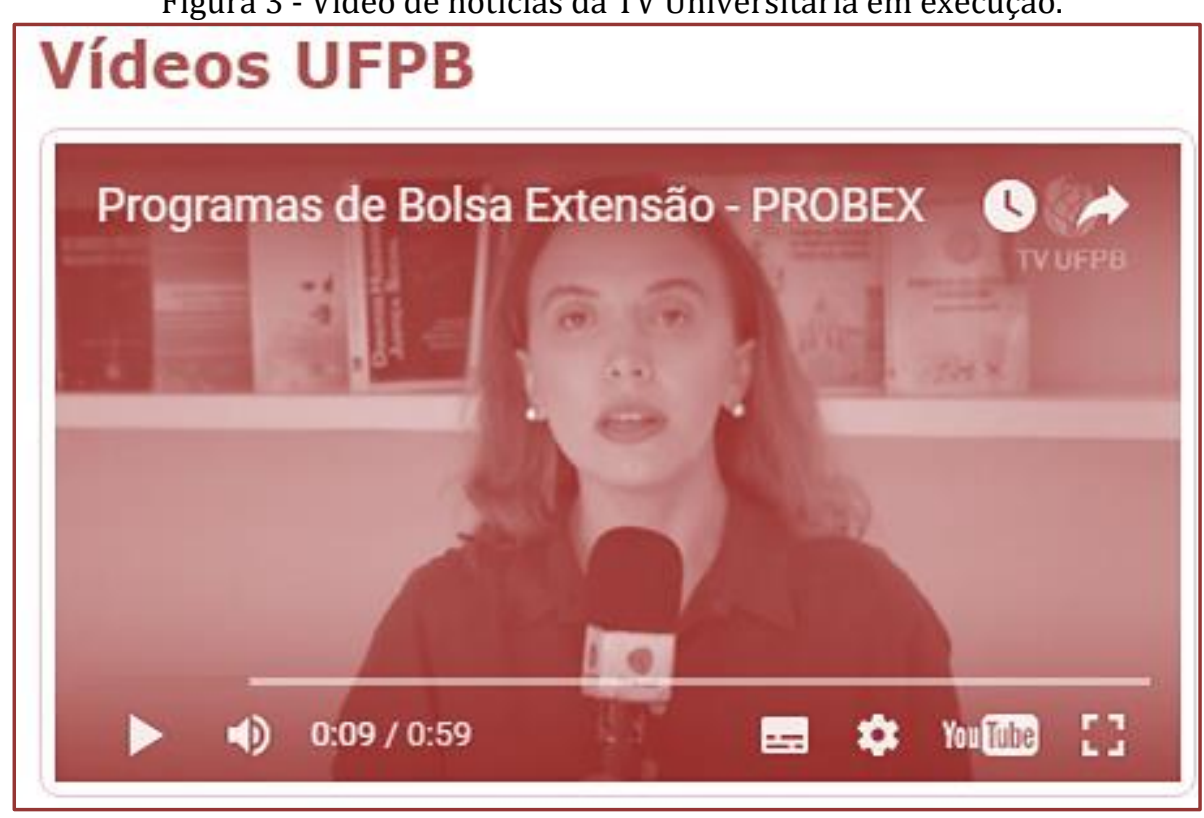

A ajuda contextualizada é essencial para evitar erros, uma vez que a probabilidade de usuários com deficiência cometerem alguns erros é muito maior, ao navegar em uma página $W e b$, do que para usuários sem deficiência. A ajuda contextualizada auxilia os usuários a efetuar uma tarefa sem se esquecer de outras que eles estavam executando. A mesma deve aparecer de forma clara em uma página Web para que o usuário possa consultá-la sempre que for necessário (WCAG 2.0, 2008).

As páginas analisadas na pesquisa não apresentam um link de ajuda contextualizada (Figura 4). Assim, segundo as WCAG 2.0, a ajuda deve aparecer na forma de um link que conduz a uma página de ajuda com informações específicas dessa página Web. A apresentação das informações de ajuda em uma nova janela do browser garante que todos os dados que foram introduzidos no formulário não sejam perdidos.

Figura 4 - - Ausência de ajuda contextualizada na página inicial do portal da IFES.

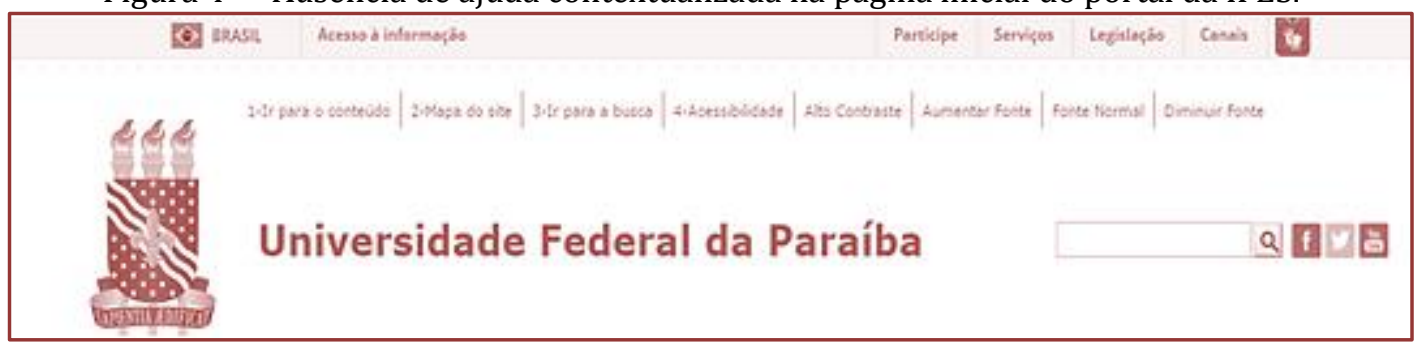

De acordo com as WCAG 2.0, a descrição do link deve permitir que um usuário diferencie este link de outros na página $W e b$, além de auxiliá-lo a determinar se deve ou não seguir o link. Não é recomendada a utilização de links do tipo "clique aqui", pois esta expressão não faz sentido fora do contexto. 
O portal da UFPB apresenta problemas relacionados aos links, pois, mesmo não possuindo o "Clique aqui" e o "Veja mais", os links estão difíceis de serem percebidos, pois não apresentam cor diferenciada dos demais elementos da página, como mostra a Figura 5.

Figura 5- Links na página Centros de Ensino do portal da UFPB

\begin{tabular}{|c|c|}
\hline $\begin{array}{l}\text { Consuatta Elehtorat } \\
\text { Reitoria } 2016\end{array}$ & Centros de Ensino \\
\hline Centros de tessino & $\begin{array}{l}\text { - Camplis I - Jasa Pessos } \\
\text { - Centro de Clencias Exatas e da Natureza }\end{array}$ \\
\hline Universidade & - Centro de Cancias Medicas \\
\hline Particlpativa & - Contro de Educas3o \\
\hline Concursos & $\begin{array}{l}\text { - Centro de Tecrofogia } \\
\text { - Centro de Cuencias do }\end{array}$ \\
\hline Comistises & $\begin{array}{l}\text { - Centro de Ciencias funidicas } \\
\text { : Centro de Bfotecnologias }\end{array}$ \\
\hline tstatuinte & $\begin{array}{l}\text { - Centro de Comunicacalo, Turismo e Artes } \\
\text { - Contro de Energias Aternativas e Renovdveis }\end{array}$ \\
\hline Assent, Comuaitarios & $\begin{array}{l}\text { - Centro de Informatica } \\
\text { - Centro de Tecrologla e Deseavalvimento Reglonal - Unidade Lynaido CavaleantuMMangubelta }\end{array}$ \\
\hline
\end{tabular}

\section{CONSIDERAÇÕES FINAIS}

O desenvolvimento desta pesquisa permitiu realizar algumas considerações relevantes para problematizar acerca da importância da acessibilidade virtual: um estudo sobre acessibilidade, usabilidade e comunicabilidade em conteúdos digitais.

A partir de análises dos portais, a saber: Universidade Federal do Rio Grande do Sul (UFRGS), Universidade Federal de São Paulo (Unifesp), Universidade de Brasília (UNB), Universidade Federal do Ceará (UFC), Universidade Federal da Paraíba (UFPB), Universidade Federal do Pará (UFPA). Quanto ao seu nível de conformidade com as recomendações das WCAG 2.0 e eMag 3.1, é possível afirmar que todas as nove páginas selecionadas para serem avaliadas não atingiram o nível mínimo de conformidade. Ou seja, todas as páginas avaliadas estão em desconformidade com as recomendações, além de implicar um desacordo com a legislação brasileira, que defende a obrigatoriedade dos sites e portais do governo brasileiro de garantir critérios mínimos de acessibilidade.

Este estudo mostrou que as avaliações automáticas realizadas nos portais contribuíram com um levantamento dos principais problemas de acessibilidade encontrados, dentre os quais se destacam: imagens de caráter informativo, como a ausência de legendas; texto alternativo (informado por meio do atributo alt); multimídia e conteúdo de vídeo sem legendas e interpretação em língua de sinais, dentre outros. Tudo isso prejudica a compreensão do conteúdo pelas pessoas surdas ou com dificuldades de audição, sendo necessária a correção dos problemas em relação aos links dessas páginas para promover de fato a acessibilidade digital.

De outro lado, este estudo evidenciou que a adoção de práticas para a promoção de acessibilidade web não exige custos elevados, uma vez que existem muitas ferramentas de avaliação automática e recomendações internacionais e nacionais disponíveis gratuitamente na Web. Essas ferramentas podem ser utilizadas por desenvolvedores a fim de aplicá-las em futuros projetos de sites acessíveis.

Contudo, a utilização de uma ferramenta de avaliação automática de níveis ou padrões de acessibilidade foi importante para auxiliar no processo de avaliação dos sites propostos. Como continuação deste estudo, procura-se ampliar as discussões acerca de critérios de avaliação e análises sobre uma avaliação mais detalhada a fim de avaliar os critérios de sucesso das WCAG 2.0 e eMAG 3.1.

\section{REFERÊNCIAS}

[1] Alonso, F. et. al. On the testability of WCAG 2.0 for beginners, Proceedings of the 2010 Internacional Cross Disciplinary Conference on Web Accessibility (W4A). Raleigh, Carolina do Norte, abr. 2010. Disponível em <http://oa.upm.es/7574/1/INVE_MEM_2010_77466.pdf>. Acesso em: 28 mar. 2016.

[2] Barbosa, S. D. J.; Silva, B. S. da. Interação Humano-computador. Rio de Janeiro: Elsevier, 2010.

[3] E-Mag 3.1. 2014. Modelo de Acessibilidade de Governo Eletrônico 3.1. Disponível em: <http://www.governoeletronico.gov.br/>. Acesso em: 30 mar. 2016. 
[4] Freire, A. P. Acessibilidade no desenvolvimento de sistemas Web: um estudo sobre o cenário brasileiro. Dissertação (Mestrado em Ciências de Computação e Matemática Computacional) - Instituto de Ciências Matemáticas e de Computação - ICMC-USP, São Carlos, 2008.

[5] Freire, A. P. Disabled people and the Web: user-based measurement of acessibility. Tese (Doutorado em Phisosophy) - Department of Computer Science - University of York, York, 2012.

[6] Harper, S.; Yesilda, Y. Web Accessibility and Guidelines. In: Web Accessibility - A Foundations for Research, Springer - Verlag London Limited, 61-78, 2008.

[7] International Standards Organization (1998) 'ISO 9241-11 - Ergonomic requirements for office work with visual display terminals (VDTs)-Part 11: guidance on usability - Part 11: guidance on usability',

[8] International Standards Organization (2008) 'ISO 9241-171: Ergonomics of human-system interaction. Part 171: Guidance on software accessibility', Junior, S. M. J. de; Almeida, G. W. de. Avaliação de Acessibilidade Web: Um estudo de caso em Sítios do Governo. Monografia (Bacharelado em Ciência da Computação) - Universidade de Brasília - UnB, Brasília, 2009.

[9] Kelly, B. An accessibility analysis of UK university entry points. Ariadne Issue 33 - University of Bath, Bath UK, 2002. Disponível em <http://www.ariadne.ac.uk/issue33/web watch>. Acesso em: 18 maio 2016.

[10] Queiroz, M. A. de. Acessibilidade web: tudo tem sua primeira vez. Bengala digital. 2007. Disponível em: <http://www.bengalalegal.com/capitulomaq.php>. Acesso em: 24 mar. 2016.

[11] Ribeiro, D. M. Vantagens Corporativas da Aplicação dos Padrões Web Voltados para Acessibilidade e Usabilidade. Monografia (Especialização em Gestão Estratégica da Informação) - Escola de Ciência da Informação, Universidade Federal de Minas Gerais - UFMG, Belo Horizonte, 2006.

[12] Rodrigues, S. S. Estudo Sobre a Acessibilidade do Portal de uma Instituição de ensino Superior. 2013.
Disponível Disponível <http://repositorio.ufla.br/bitstream/1/5486/1/Monografia_Estudo_sobre_a_acessibilidade_do_portal_de_uma_instit uicao_de_ensino_superior.pdf >. Acesso em: 17 maio 2016.

[13] Santarosa, L. M. C. Telemática y la inclusión virtual y social de personas con necesidades especiales: un espacio posible en la Internet - RIBIE 2000 - Chile. Disponível em: <http://www.c5.cl/ieinvestiga/actas/ribie2000> Acesso em: 23 mar. 2016.

[14] Sloan, D. et. al. Auditing accessibility of UK higher education web sites. Interacting with Computers - p. 313$325,2002$.

[15] Trentin, C. 0 que é acessibilidade para você? 2007. Disponível em: <http://cristiantrentin.com.br/blog/index.php/o-que-e-acessibilidade-para-voce/>. Acesso em: 3 jul 2007.

[16] Wcag 2.0. 2008. Web Content Accessibility Guidelines (WCAG) 2.0. 2008. Disponível em: <http://www.w3.org/TR/WCAG20/>. Acesso em: 29 mar. 2010. 


\section{Capítulo 21}

Reflexões sobre a formação de professores de língua portuguesa em contexto escolar: Um estudo comparativo entre teoria e prática

\section{Paulo Ricardo Ferreira Pereira}

Luciene Maria Patriota

Resumo: No Brasil, as discussões referentes à conjuntura educacional e à formação docente não são recentes. Na área de ensino de línguas, essas discussões referem-se, em especial, ao ensino meramente gramatical, o qual está alicerçado em concepções tradicionais, sendo alvo de discussões consideráveis desde 1980 (BAZARIM e APARÍCIO, 2009). Neste ensino, põem-se de lado os atos reflexivos do aluno, assim como a atuação reflexiva do professor, tornando a prática pedagógica um ato mecânico calcado em concepções paradigmáticas tradicionais. Diante disto, este estudo objetiva discutir a caracterização do profissional atual da área do magistério de língua portuguesa, a partir de observações de práticas educativas realizadas em contexto de sala de aula, comparando-as com as teorias educacionais do paradigma tradicional e do paradigma emergente. Como consequência dessa caracterização, suscitam-se questões referentes à formação docente e ao perfil identitário desse profissional educacional. Teoricamente, subsidiamo-nos, como aporte teórico, nas considerações de autores como Kuhn (1992), Perrenoud (2002), Flach e Behrens (2008), Ribeiro et. al. (2010), dentre outros. Metodologicamente, esta pesquisa caracteriza-se como qualitativa de natureza descritivo-interpretativista. Através da relação entre teoria e prática realizada, constatamos que, na atualidade, o perfil do profissional de docência caracteriza-se por manter-se tanto enraizado em concepções paradigmáticas tradicionais como emergentes, a fim de manter-se flexível, mas detentor de uma base em suas práticas educativas, a qual lhe propicie um norte. Nesse sentido, a construção identitária do profissional do ofício de magistério encontra-se nesta constante entre o agir tradicional e o agir inovador, o que possibilita atitudes reflexivas em sua atuação, seja consciente ou inconscientemente. Quanto à formação docente, isso aponta que os cursos direcionados à formação de professores devem alicerçarem-se em uma filosofia educacional que privilegie o estudo a partir das práticas reflexivas, tanto do corpo docente como do discente, a fim de que a instituição escolar possa corresponder aos anseios socioeducacionais dos alunos.

Palavras-Chave: Paradigmas educacionais; Teoria e prática; Identidade docente; Formação docente. 


\section{INTRODUÇÃO}

A escola, cada vez mais, demanda práticas que acompanhem os avanços (científicos, tecnológicos, sociais etc) que compõem a sociedade em que ela se situa. Esse cenário resulta, em particular, do paradigma que a constitui enquanto instituição socioeducacional. Nessa direção, de acordo com Flach e Behrens (2008, p.10123), "desde o final do século XX, vive-se uma transição paradigmática, buscando um novo paradigma que demanda uma revisão na visão de mundo, de sociedade e de homem" e, consequentemente, das práticas que integram os âmbitos sociais. Essa busca por um novo paradigma é evidenciada e explicada pelo ciclo paradigmático de Thomas Kuhn (1992), por meio do qual ele expõe a sua visão sobre a construção da ciência e do conhecimento científico.

Nesse ciclo paradigmático, Kuhn (1992) pontua que os paradigmas se originam a partir de um paradigma antigo, sendo que o novo surge para corresponder às demandas não solucionadas pelo anterior. Conforme esse autor, o novo paradigma deve resolver as questões não solucionadas pelo paradigma até então em vigência, independentemente da área em que ele se encontra. Sob esse ângulo, a ciência não é vista apenas como o acúmulo gradual de conhecimentos, mas como um ciclo constante constituído por paradigmas. É essa noção que alicerça a compreensão da perspectiva kuhniana.

As concepções paradigmáticas se refletem em diversos campos profissionais, tanto na abordagem teórica como na prática. Na área educacional, como nos asseguram Ribeiro et al. (2010, p.28), "nota-se que a Educação de hoje ainda traz em seu bojo ações e valores pautadas no cartesianismo e mecanicismo da ciência moderna e, por conseguinte, instrui alunos para o futuro com um pensamento tradicional do passado". Nesse sentido, o campo educacional insere-se no ciclo paradigmático, proposto por Kuhn (1992), a partir do momento em que não corresponde mais aos anseios socioeducacionais dos corpos discente e docente, visto que, como nos apontam Flach e Behrens (2008), as práticas pedagógicas precisam ser compatíveis com esta nova leitura de mundo, que demanda novas estratégias e práticas de ensino e aprendizagem.

Ao discutir essas concepções paradigmáticas, Ribeiro et al. (2010) ressaltam e caracterizam duas tipologias: o Paradigma Tradicional e o Paradigma Emergente ${ }^{27}$. De modo semelhante, Flach e Behrens (2008) compreendem os paradigmas a partir de dois tipos: Paradigmas Conservadores e Paradigmas da Complexidade. Conforme a leitura daqueles autores, na interface do Paradigma Tradicional, em razão das ciências naturais, exigia-se da educação o compromisso de acompanhar os avanços científicos. Dessa maneira, "acreditava que a Educação deveria fundamentar-se no conhecimento objetivo das ciências naturais" (RIBEIRO et. al., 2010, p.32), que passa a ser refletida e concebida no campo educacional a partir da racionalidade e cientificidade. Nesta concepção tradicional, a educação é compreendida como moderna. De acordo com esses autores, nesta educação moderna,

o que não é científico, calcado no cartesianismo e no mecanicismo, é desconsiderado. É uma Pedagogia induzida, behaviorista, a qual se baseia na transmissão do conhecimento pelo professor e no acúmulo do mesmo pelos alunos. Enfatiza-se o conteúdo programático, com vistas a instruir uma futura mão-de-obra técnica para o mundo do trabalho - de acordo com a demanda e os interesses da sociedade desenvolvimentista capitalista. 0 erro é tido como algo ruim e deve ser evitado. 0 importante é o resultado eficiente, as notas, ou melhor, o produto final. (RIBEIRO et. al., 2010, p.33-34)

Como nos assegura o fragmento acima, nesta concepção paradigmática de ensino, os alunos são direcionados para o futuro em uma concepção pedagógica alicerçada ainda no passado, a qual preconiza meramente a memorização, a fim de atingir resultados de cunho racionais, pois, como nos mostra a citação de Ribeiro et al. (2010), o que importa para esta concepção educacional é o resultado eficiente do produto final, não o processo ou os sujeitos imbricados nele.

Ainda em conformidade com Ribeiro et. al. (2010, p.36), o Paradigma Emergente "apresenta uma leitura de mundo globalizante, holística, o que implica em uma nova ordem: a totalidade indivisível", que ressalta o homem como um todo, ou seja, como um ser dotado de aspectos biopsicossociais e socioculturalmente situado. Nesta concepção paradigmática, ainda de acordo com os autores, a educação é compreendida como pós-moderna, sobretudo por centrar-se em um sujeito coletivo. Segundo Ribeiro et al. (2010, p.37), esta educação pós-moderna,

27 Neste trabalho, associamo-nos às concepções de Paradigma Tradicional e Paradigma Emergente (RIBEIRO et. al., 2010) em decorrência de nossas afiliações teórico-metodológicas. 
se preocupa com o processo de assimilação e acomodação, como também com a construção do saber de forma dialógica e criativa. É uma Pedagogia contextualizada, recursiva, interdependente com o Universo e que, por conta disso, é vista como um sistema aberto. Essa noção de interdependência na Educação se calca nas interações entre os diversos elementos que a compõem, tais como as disciplinas, a sua direção e administração, os docentes, os discentes, a comunidade, os pais, os funcionários, dentre outros. E ainda, é uma Educação comprometida com a valorização das experiências vividas subjetivas dos sujeitos educandos e com a sua formação política e ética, tendo em vista os conflitos étnico-culturais, a autoconsciência ecológica e os princípios humanitários.

De modo semelhante, ao discutirem os tipos que constituem o paradigma da complexidade, Flach e Behrens (2008, p.10128) compreendem que,

ser educador nos dias atuais depende da opção paradigmática que pode possibilitar um ensino que contemple o aluno como um todo, que entenda a sociedade e as suas reais necessidades, que permita a formação de seres humanos críticos, produtores de conhecimento, trabalhando com uma educação que resgate os valores e que seja acima de tudo um ato de amor.

É nesta concepção paradigmática emergente/da complexidade que se encontra o profissional reflexivo. Como nos aponta Perrenoud (2002), este profissional caracteriza-se por sua prática reflexiva, na qual há uma postura, uma caracterização identitária, enfim, um habitus, que o qualifica como um profissional reflexivo em sua atuação. Para isso, deve-se haver, consequentemente, uma mudança em sua formação, visto que para formar um profissional reflexivo, "é preciso formar pessoas capazes de evoluir, de aprender de acordo com a experiência, refletindo sobre o que gostariam de fazer, sobre o que realmente fizeram e sobre o resultado de tudo isso" (PERRENOUD, 2002, p.17). Portanto, é preciso "orientar com clareza a formação dos professores para uma prática reflexiva, valorizar os saberes advindos da experiência e da ação dos profissionais e desenvolver uma forte articulação teoria-prática (...)" (PERRENOUD, 2002, p.90) em contexto escolar.

A partir dessas considerações teóricas (KUHN, 1992; FLACH e BEHRENS, 2008; RIBEIRO et. al., 2010; PERRENOUD, 2002), realizamos a presente pesquisa em contexto escolar, na qual, por meio de observações escolares realizadas em uma das instituições escolares do estado da Paraíba, pudemos ter contato com a sala de aula de Língua Portuguesa, analisando, em específico, as práticas educacionais de um dos professores da instituição. Este professor ${ }^{28}$ atua na área educacional há mais de dez anos e a sua formação reflete um outro período institucional do saber. À medida que o agradecemos por nos conceder o espaço escolar de duas turmas em que leciona, ressaltamos que elas são compostas por um público divergente, pois alguns alunos encontravam-se no $2^{\circ}$ ano do Ensino Médio, enquanto outros estavam na 4o série do Ensino Fundamental, por exemplo. Por essa razão, as turmas são constituídas pela presença de alunos do Pro-Jovem Urbano, na modalidade de ensino Educação de Jovens e Adultos (EJA).

Neste trabalho, evidenciamos a relação estabelecida entre as teorias expostas pelos autores (FLACH e BEHRENS, 2008; RIBEIRO et. al., 2010) com a prática do referido professor. Em decorrência disso, analisamos a atuação deste professor à luz das teorias paradigmáticas tradicional e emergente. Desse modo, constitui-se como objetivo discutir a caracterização paradigmática que prevalece no profissional atual do magistério de língua portuguesa, ou seja, se esse profissional se caracteriza por agir tradicionalmente ou de forma inovadora. A partir desta caracterização, suscitam-se questões pertinentes que envolvem o perfil identitário desse profissional e, consequentemente, implicações referentes à formação docente na contemporaneidade.

Este estudo, portanto, está estruturado pela presente introdução, que explicita as bases teóricas e os objetivos que norteiam o trabalho, e, em seguida, pela metodologia utilizada para a realização da pesquisa. Em sequência, na seção de análise de dados, comparamos e discutimos os resultados obtidos à luz de nosso aporte teórico e metodológico. Como forma de concluir, tecemos as considerações finais, de forma a destacar pontos sobre o perfil identitário e formação docente do profissional de língua portuguesa em atuação escolar.

\footnotetext{
${ }^{28}$ Ao professor e às turmas selecionadas, agradecemos a acolhida amistosa e os reconhecemos como fundamentais para o desenvolvimento de nosso trabalho.
} 


\section{METODOLOGIA}

Metodologicamente, o presente trabalho caracteriza-se como uma pesquisa qualitativa de natureza descritiva e interpretativa. Conforme Minayo (1995, p.21-22),

a pesquisa qualitativa responde a questões muito particulares. Ela se preocupa (...) com um nível de realidade que não pode ser quantificado. Ou seja, ela trabalha com o universo de significados, motivos, aspirações, crenças, valores e atitudes, o que corresponde a um espaço mais profundo das relações, dos processos e dos fenômenos que não podem ser reduzidos à operacionalização de variáveis.

Associando-nos a esse paradigma qualitativo, analisamos os resultados obtidos na linha da descrição e interpretação, de modo a demonstrar o percurso traçado e evidenciado em contexto escolar, o que torna improvável uma postura neutra dos pesquisadores (ANDRÉ, 1995; SEVERINO, 2016). Na seção seguinte, discutimos os resultados decorrentes dos dados obtidos, que foram extraídos de observações realizadas durante cinco semanas em uma instituição pública de ensino do estado da Paraíba. Para isso, os resultados que se seguem foram retirados de blocos de anotações, os quais foram utilizados como forma de evidenciar e elucidar as situações presenciadas em contexto escolar pelos pesquisadores.

\section{RESULTADOS E DISCUSSÃO}

Os dados obtidos nos permitem organizar esta seção em dois momentos: no primeiro, discutimos sobre as práticas educacionais que evidenciam o paradigma tradicional; no segundo, ressaltamos as práticas que demonstram o paradigma emergente. No final desta seção, elaboramos um quadro que sintetiza os resultados verificados. Essa disposição é desenvolvida a partir da seleção de fragmentos das situações vivenciadas em sala de aula, as quais seguem abaixo:

Ao decorrer das aulas presenciadas, no que tange ao Paradigma Tradicional, destacamos os seguintes dados:

Logo nas primeiras aulas analisadas, o professor nos demonstrou fortes nuances do paradigma tradicional. Em uma das aulas, ao orientar os alunos para resolverem a atividade, o professor utilizava-se de uma abordagem prescritiva, visto que ele falava como queria as respostas da atividade, deixando de lado a subjetividade do aluno, incorporando, assim, as concepções paradigmáticas tradicionais. Ao término da aula, ele demonstrou-nos mais uma abordagem enraizada na concepção paradigmática tradicional, ressaltando que "quem fez o cartaz sobre o dia do estudante, ganhará 10" e quem não o fez, "está sem nota".

Na aula seguinte, ainda abordando à produção de cartazes, o professor demonstrou atitudes enraizadas na perspectiva de ensino tradicional, principalmente por ressaltar que "quem não quiser fazer os cartazes, pode ir para fora (da sala de aula)" e por pontuar as atividades no caderno como critérios para nota, além da presença e participação em sala, e quem não os tivesse, "só lamento" - como fora dito por ele em sala ao invés de tentar compreender ou pontuar outros critérios para se obter um outro resultado, isto é, um resultado almejado por ambos na relação entre professor-aluno, pois, como propõe Maia (2009), o professor deve desenvolver uma atuação socialmente comprometida, de forma a contextualizar o conteúdo a ser abordado, possibilitando também a participação do aluno enquanto sujeito ativo no corpo social, o que implica atribuir voz a este aluno em todas as instâncias através de um movimento dialógico.

Iniciando uma nova aula, o professor ressaltou que os alunos pegassem os livros e fizessem a atividade proposta em tal página. Quando era questionado novamente sobre a página, o professor repreendia os alunos, mas, ainda assim, explicava novamente. Em um momento de aflição, um dos alunos proferiu que "não entendi essa (questão), homem", o professor respondeu que "então marca a que você achou que é (a correta)". A partir dos teóricos que nos fundamentam, compreendemos que atitudes como a primeira pegar o livro e fazer a atividade - é aceitável a depender do contexto, pois há situações educacionais que exigem posturas como esta em sala.

Ainda ao decorrer da referida aula, o professor ressaltou que só daria visto - uma herança forte do paradigma tradicional de ensino - após todas as perguntas terem sido respondidas. Enquanto os alunos levavam as atividades para sua observação, o professor utilizava-se das técnicas de correção propriamente tradicionais: as concepções de certo e errado, as quais avaliavam exercícios de fixação e de produção textual. Neste caso, esses exercícios de fixação, oriundos dos livros didáticos, para Batista (1997), são veemente inerentes ao paradigma tradicional de ensino, assim como a seleção de materiais 
didáticos (no caso, o LDP) e a preferência do destaque de determinado conteúdo pelo professor, sendo, neste caso, os aspectos gramaticais da língua, visto que isso pode se distanciar dos interesses formativos dos alunos em determinado contexto.

Na aula da semana seguinte, o professor propôs uma nova produção textual, que enfatizava a vida interacional dos alunos na plataforma da internet, no entanto, os alunos deveriam dissertar a partir das palavras que constavam no texto base, o qual estava veiculado no livro didático de língua portuguesa (LDP), ressaltando que eles retirassem do texto base - como enfatiza Batista (1997), o texto como pretexto - determinadas palavras que deveriam constar nas produções textuais. Através desta atitude do professor, percebemos a prevalência de comportamentos educacionais que caracterizam o paradigma tradicional, visto que neste tipo paradigmático, segundo Flach e Behrens (p.10121, 2008), o aluno é tido como um ouvinte, receptivo e passivo, ao passo que o professor é considerado o "dono da verdade", o qual mantém comportamentos e atitudes autoritárias no contexto escolar. Nesse sentido, evidencia-se, mais uma vez, que o professor deixa de lado o subjetivismo do aluno ao moldar as produções textuais destes, alicerçando-se, consequentemente, em uma abordagem prescritiva, a qual está preconizada em uma perspectiva tradicionalista.

Com relação a atividade em si, quando um certo aluno ressaltou que "a proposta é ['hĩ]" ortograficamente, ruim - o professor, através de uma entonação sarcástica, enfatizou no ['hî] do aluno, ressaltando que "tem nada de RUIM" na atividade. Através dessa postura, percebemos a influência direta do paradigma tradicional, uma vez que o professor não pega a deixa da ocasião e a coloca como uma pauta de discussão, mas, sim, utiliza-a pejorativamente, oprimindo, de forma inconsciente, o aluno por sua variedade linguística, a qual é explicada por estudiosos da área de linguagens, especificamente pela corrente Sociolinguística. Ao decorrer da aula, percebemos a ausência da participação dos alunos, talvez em consequência da atitude de cunho autoritário do professor em "corrigir" o aluno na modalidade oral da língua, visto que, como nos assegura Batista (1997), estas ações corretivas e coercivas, além de causar a hierarquização e estratificação social e escolar, podem inibir a atuação do aluno em contexto escolar, tornando-o meramente um ser receptivo e o professor o ser dominante, ou, no caso do paradigma tradicional de ensino, o detentor da verdade (FLACH e BEHRENS, 2008; BATISTA, 1997).

$\mathrm{Na}$ aula do dia seguinte, as atividades foram continuadas e orientadas pelo uso exclusivo do livro didático de língua portuguesa (LDP), contendo apenas o auxílio individual quando o aluno solicitava a ajuda do professor. Retornando às atividades, o professor propôs a leitura de um texto, o qual seria lido em voz alta pelos próprios alunos. Enquanto os alunos liam timidamente, o professor ajudava-os na pronúncia de certas palavras, principalmente quando ocorria a pronúncia inadequada por parte deles, neste caso, ocorria a correção das palavras, embora sem fins caricatos e/ou pejorativos. Nesta aula, sumamente, percebemos a nuance de ambos paradigmas, sobretudo pelo professor dialogar tanto nas concepções tradicionais como nas emergentes.

No que se refere ao Paradigma Emergente, destacamos as seguintes situações:

Enquanto lecionava, o professor, na maioria das aulas presenciadas, pedia que os alunos relacionassem e refletissem sobre o que estava sendo abordado em sala com a realidade deles. Em uma das atividades aplicadas em sala de aula, pontuavam-se quais eram as concepções de aluno, de escola e educação e de cidadania para o próprio estudante, ou seja, há nuances de uma abordagem reflexiva do aluno sobre o seu próprio papel no cerne socioeducacional. Ao término da aula, o docente propôs uma atividade de pesquisa sobre substantivo e coletivo. A partir deste ato de pesquisa, temos, portanto, influência do paradigma emergente, em especial à concepção paradigmática que preconiza o ensino com pesquisa (FLACH e BEHRENS, 2008). Nesta referida concepção paradigmática, o professor utiliza-se de a filosofia educacional "aprender a aprender", instigando, assim, o aluno a avançar com autonomia, visando promover o seu distanciamento da reprodução do conhecimento à medida que o instiga a produzi-lo (FLACH e BEHRENS, p.10126-10127, 2008).

Em uma das aulas, ao término de dada atividade, a qual se enquadra nas concepções tradicionais, o professor propôs uma outra. Nesta atividade, também referente a um texto sobre tecnologia presente no LDP, ele questionou aos alunos sobre o que eles caracterizavam como tecnologia. A partir das respostas obtidas, o professor as colocou em evidência, partindo delas, ou seja, da realidade dos alunos, para contextualizar o conteúdo a ser trabalhado naquele momento, enfatizando que o sabonete - além dos sprays, esmaltes e eletrodomésticos - foi uma tecnologia para a época de sua fabricação, alertando-os sobre os pontos positivos e negativos das tecnologias ao longo da história. Nesta atividade, a partir do momento em que o professor parte das respostas e da realidade dos alunos, percebemos que ele se insere na acepção de uma pedagogia contextualizada socialmente, pois, como nos asseguram Ribeiro et al. 
(2010), essa concepção pedagógica se preocupa não só com o processo de ensino por parte do professor, mas também com o processo de assimilação dos alunos.

Assim como na situação exposta acima, em um certo momento de uma outra aula, um dos alunos falou que não sabia o que era rima. Diante disto, o professor ao ver que se tratava de um assunto também presente no texto que estava sendo trabalhado pelos alunos, abriu a questão para discussão em sala, explicando, posteriormente, a dúvida do aluno, contextualizando-a e socializando-a para a compreensão plena dele.

De maneira geral, a partir da análise comportamental e atitudinal realizada à luz das teorias paradigmáticas eleitas neste estudo, percebemos que os paradigmas educacionais encontrados no professor, em sua maioria, estão em sua postura pedagógica, em especial, em seu relacionamento com os alunos, além disto, percebemos a prevalência de ambos paradigmas nas aulas analisadas, a divisão realizada foi apenas em razão de fins didático-expositivos. Nesse sentido, evidenciamos a dualidade paradigmática encontrada neste profissional do ofício de magistério que ora é tradicional, ora inovador.

Em suma, sintetizando os resultados obtidos, destacamos os seguintes dados encontrados nas práticas pedagógicas do professor:

Quadro 1 - Concepções paradigmáticas verificadas e que influenciaram as práticas do professor

\begin{tabular}{|c|c|}
\hline PARADIGMA TRADICIONAL & PARADIGMA EMERGENTE \\
\hline $\begin{array}{l}\text { Orientações com os alunos de forma } \\
\text { prescritiva }\end{array}$ & $\begin{array}{l}\text { Relacionar/refletir o assunto em sala com a } \\
\text { realidade do aluno }\end{array}$ \\
\hline Concepções de certo e errado & $\begin{array}{l}\text { Fomentar a autonomia do aluno por meio da } \\
\text { pesquisa }\end{array}$ \\
\hline Atitudes coercivas/corretivas & $\begin{array}{l}\text { Contextualizar o tema proposto a partir da } \\
\text { realidade e das dúvidas dos alunos }\end{array}$ \\
\hline
\end{tabular}

Fonte: Os autores (2017)

O quadro exposto nos mostra que os resultados obtidos se referem a ambas concepções paradigmáticas. Neste sentido, percebemos que há uma dualidade nas práticas pedagógicas do professor analisado em sua atuação escolar, pois ora ele age tradicionalmente, ora de forma emergente, marcando, assim, a sua atuação escolar por esta mescla paradigmática, principalmente porque, na atualidade, as necessidades do corpus educacional os exigem, uma vez que o tradicional estar incorporado e alicerçado no cerne socioeducacional e o emergente surge como uma possibilidade de conciliar as novas demandas sociais da educação. Por esta razão, é válido ressaltar a formação continuada do professor atuante em sala, visto que estas novas demandas da classe educacional, principalmente no que se refere ao ensino de línguas, exigem que este professor esteja em constante atualização, caracterizando-o, sobretudo, como um pesquisador, o qual atua de forma reflexiva no contexto escolar (PERRENOUD, 2002).

\section{CONSIDERAÇÕES FINAIS}

Neste estudo, propomo-nos a discutir a caracterização do profissional atual da área do magistério de língua portuguesa. Para isso, a partir de blocos de anotações decorrentes das observações de práticas educativas em contexto escolar de um professor dessa modalidade, realizamos uma análise comparativa entre as práticas evidenciadas pelo professor, tanto comportamental como atitudinal, com as teorias educacionais paradigmáticas tradicional e emergente, tangenciando o obtido com considerações sobre sua construção identitária e formação docente.

Conforme análise, constatamos que, na atualidade, esse perfil do profissional da docência, especificamente de língua portuguesa, caracteriza-se por se manter tanto enraizado em concepções paradigmáticas tradicionais como emergentes. Desse modo, a sua construção identitária encontra-se nesta constante entre o agir tradicional e o agir inovador, possibilitando, em razão disto, atitudes reflexivas em sua atuação prática, seja consciente ou inconscientemente (PERRENOUD, 2002).

No que se refere à formação docente, isso aponta que os cursos direcionados à formação de professores devem alicerçarem-se em uma filosofia educacional que privilegie o estudo a partir das práticas reflexivas, tanto do corpo docente como do discente, a fim de que a instituição escolar, enquanto lócus da socialização e construção de saberes, possa corresponder aos anseios socioeducacionais dos alunos. Como nos assegura Perrenoud (2002, p.104), essa formação de profissionais reflexivos se torna necessária e, 
consequentemente, um "objetivo explícito e prioritário em um currículo de formação dos professores", assim, "em vez de ser apenas uma familiarização com a futura prática, a experiência poderia, desde a formação inicial, assumir a forma simultânea de uma prática "real" e reflexiva".

Reiteramos, ainda, que a relação paradigmática verificada nas práticas educacionais do professor é vista como decorrente da transição paradigmática (KUHN, 1992) que vivenciamos, bem como a sua caracterização identitária. Esperamos, portanto, que este estudo contribua e seja profícuo para (re)pensarmos as políticas educacionais, principalmente as referentes à formação docente dos profissionais de língua portuguesa, visto a discussão ora exposta.

\section{REFERÊNCIAS}

[1] André, M. E. D. A. Etnografia da prática escolar. Campinas: Papirus, 1995.

[2] Batista, Antônio Augusto Gomes. O Português que se ensina. In: Aula de Português: Discurso e Saberes Escolares. São Paulo: Martins Fontes, 1997.

[3] Bazarim, M.; Aparício, A. S. M. Gramatização: Uma (outra) forma de olhar a gramática e seus impactos de seleção dos objetos de ensino de língua portuguesa. Língua \& Educação, v. 01, p.01 - 09, 2009.

[4] Flach, Carla Regina de Camargo; Behrens, Marilda Aparecida. Paradigmas Educacionais e sua influência na prática pedagógica. Disponível em: <www.pucpr.br/eventos/educere/>. Acesso em: 16 junho 2016.

[5] Geraldi, João Wanderley. A aula como acontecimento. São Carlos: Pedro e João Editores, 2010.

[6] Kuhn, Thomas Samuel. A Estrutura das Revoluções Científicas. São Paulo: Perspectiva, 1992.

[7] Maia, Cristiane Martinatti. Escola e professor: função social. In: Maia, Christiane Martinatti; Scheibel, Maria Fani; Urban, Ana Claudia. Didática: Organização do Trabalho Pedagógico. Curitiba: IESDE Brasil S.A., 2009.

[8] Minayo, Maria Cecília de Souza (Org.). Pesquisa social: teoria método e criatividade. Petrópolis, RJ: Vozes, 1994.

[9] Perrenoud, Philippe. A Prática Reflexiva no Ofício de Professor: profissionalização e razão pedagógica. Porto Alegre: Artmed Editora, 2002.

[10] Ribeiro, W. C.; Lobato, W.; Liberato, R. C. Paradigma Tradicional e Paradigma Emergente: Algumas implicações na Educação. Rev. Ensaio, Belo Horizonte, v.12, n.01, p.27-42, jan-abr, 2010.

[11] Severino, Antônio Joaquim. Metodologia do trabalho científico. São Paulo: Cortez, 2016.

[12] Sousa, Maria Goreti da Silva. A formação continuada e suas contribuições para a profissionalização de professores dos anos iniciais do ensino fundamental de Teresina- Pi: revelações a partir de histórias de vida. Disponível em: <http://www.dominiopublico.gov.br/pesquisa/>. Acesso em: 21 agosto 2016. 


\section{Capítulo 22}

\section{Levantamento florístico da Praia de Intermares - Cabedelo (PB-NE)}

\section{Rita Braga Soares da Silva \\ Maria Clara Gomes da Silva \\ Priscila Santos Fidelis da Silva \\ Hermes Machado Filho}

Resumo: Localizado entre os ambientes marinho e continental, a Restinga é um ecossistema em constante mudança por processos naturais, como por exemplo a erosão e a drenagem hídrica, além de sofrer conjuntamente com a desenfreada ocupação urbana. Assim, neste estudo é apresentado o levantamento florístico de espécies em uma área costeira urbana antropizada, em Intermares, praia do município de Cabedelo no

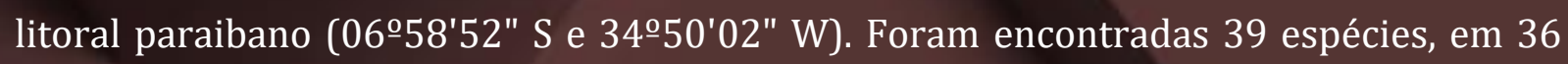
gêneros e 20 famílias. Entre elas, as famílias mais representativas foram as Fabaceae (20,5\%), Euphorbiaceae (15,4\%) e Rubiaceae (7,7\%). Predominou-se o estrato herbáceo e também as espécies autocóricas, que não precisam de agentes externos na sua dispersão. E ainda, na distribuição fitogeográfica, o maior número de plantas registradas foram as ocorrentes na província Pantropical. Infelizmente, nos últimos anos, o que se encontram na verdade são as partes remanescentes da restinga, pois o turismo e outras atividades urbanas contribuem ainda mais para que a alteração desses tipos de ambiente seja constante, ajudando consequentemente para a descaracterização da composição florística da área.

Palavras-chave: Restinga; Florística, Levantamento florístico, Zonas costeiras. 


\section{INTRODUÇÃO}

A existência de uma unidade geobotânica para a zona litorânea é notória entre vários especialistas da fitogeografia mundial. Todavia, a designação utilizada, seja para denominar e categorizar a flora litorânea, ou até para distinguir as suas referentes fitofisionomias é altamente variada. 0 próprio termo "Restinga" possui numerosas conotações, ora especifica o solo areento do relevo costeiro, ora limita-se ao tipo de vegetação que reveste o substrato e ora ao conjunto solo-flora por inteiro (SILVA, 1999).

As comunidades de restinga ocasionam-se de modo descontínuo no percurso de quase $5.000 \mathrm{~km}$ ao decorrer do litoral brasileiro (HOLZER et al., 2004). As mesmas estão sujeitas a circunstâncias ambientais intensas: elevada temperatura e salinidade, forte ocorrência de ventos, a consequente alta movimentação de partículas do substrato, carência hídrica e poucos nutrientes. Condições que circunscrevem a flora e o tipo das espécies e que impedem o crescimento de vegetação de grande porte (SCARANO, 2002).

Desse modo, é fundamental que levantamentos florísticos nessas áreas sejam realizados para o reconhecimento da fitodiversidade da zona praial que, por sua vez, possui um histórico geologicamente recente e ainda poucos estudos quando comparado à outras formações vegetais. Além disso, o desenfreado crescimento urbano sobre os remanescentes naturais desses ecossistemas ocasiona a perda de muitas espécies (FUHRO et al., 2005), e até mesmo, do registro de espécies raras. Com isso, o levantamento florístico constitui a base para a gestão ambiental de qualquer estudo de recuperação ou de conservação.

Com base nessa problemática, o objetivo desse trabalho foi realizar o levantamento florístico na praia de Intermares, Cabedelo-PB (Nordeste do Brasil) como subsídio de reconhecimento da flora.

\section{METODOLOGIA (OU MATERIAIS E MÉTODOS)}

0 estudo foi realizado na praia de Intermares, no município de Cabedelo, localizado na zona fisiográfica do litoral paraibano, entre as coordenadas $06^{\circ}-58^{\prime} 52^{\prime \prime} \mathrm{S}$ e $34^{\circ}-50^{\prime} 02^{\prime \prime} \mathrm{W}$. A área possui clima do tipo tropical úmido, cujas temperaturas variam entre a máxima de $31^{\circ} \mathrm{C}$ e mínima de $24^{\circ} \mathrm{C}$. Os meses mais chuvosos são abril, maio e junho e a precipitação média anual é de aproximadamente $1.634 \mathrm{~mm}$ (INPE, 2016).

É predominante a ocorrência de ondas que chegam à zona costeira de forma oblíqua acarretando uma deriva litorânea de sentido sul-norte. Essa característica provoca um deslocamento sedimentar praial de sul para norte, principal fator que molda as praias do município, incluindo Intermares (BARBOSA et al., 2018). Segundo Suguio et al. (2005), os cordões litorâneos de Cabedelo, formaram-se a partir da variação do nível do mar no Holoceno, onde ocorreram os eventos mais recentes da era cenozoica.

Para o levantamento florístico na área de estudo foram realizadas 4 expedições de coletas sistemáticas de material em estágio reprodutivo na área de estudo proposta, entre outubro de 2018 e maio de 2019. Todos os indivíduos férteis (flor e/ou fruto) foram coletados através de caminhamento pela areia da praia.

Os espécimes coletados foram herborizados: postos em prensas de madeira, cobertas por jornal e separadas por folhas de alumínio e papelão para acondicionar as plantas durante a secagem na estufa, que oscilava numa temperatura entre $60^{\circ}$ e $70^{\circ} \mathrm{C}$. E as mesmas foram levadas ao herbário Dárdano de Andrade Lima no Instituto Agronômico de Pernambuco (IPA) em Recife - PE.

As classificações taxonômicas foram feitas com base em literaturas especializadas e consulta a estudiosos e especialistas. Para a lista das espécies o sistema de classificação utilizado foi o proposto pelo APG IV (2016). Para determinar o hábito das espécies encontradas fundamentou-se nas terminologias propostas por Veloso et al. (1991), as síndromes de dispersão no sistema de classificação de Pijl (1972) e o espectro biológico em Raunkiaer (1934).

Os nomes das espécies e respectivos autores foram consultados na base The Plant List (2019) e na Lista de Espécies da Flora do Brasil (2019). Já os dados de distribuição fitogeográfica foram retirados da Global Biodiversity Information Facility (2019). 


\section{RESULTADOS E DISCUSSÕES}

Foram registradas 39 espécies, distribuídas em 36 gêneros e 20 famílias (Tabela 1). As famílias mais representativas foram Fabaceae $(20,5 \%)$, Euphorbiaceae $(15,4 \%)$ e Rubiaceae $(7,7 \%)$ e estas estão entre as dez famílias com maior registro de espécie citadas para outras restingas na região Nordeste por Esteves (1980), Oliveira Filho e Carvalho (1993) e Matias e Nunes (2001), demonstrando uma interrelação fitogeográfica, considerando nesse caso, apenas a nível de família. As famílias Poaceae, Convolvulaceae, Amaranthaceae e Cactaceae também foram recorrentes e correspondem a porcentagem de 5,1\% cada uma.

A predominância do estrato herbáceo foi evidenciada pelos resultados, com 82,1\% das espécies coletadas (Figura 1). Em relação às demais espécies, 5 têm hábito arbustivo e 2 têm hábito arbóreo, pois por ter substrato arenoso, e uma deficiência significativa de nutrientes, poucas espécies de grande porte conseguem se desenvolver.

Tabela 1: Lista de espécies das espécies registradas na área de estudo da praia de Intermares - Cabedelo (PB-NE). Legenda - Hábito: Erva (E), Arbusto (AB), Árvore (AV); Espectro Biológico: Caméfito Reptante (CR), Caméfito Ereto (CE), Caméfito Suculento (CS), Fanerófito (FA), Hemicriptófito (HC), Cripitófito (CP), Liana (LI); Síndrome de dispersão: Autocoria (AU), Anemocoria (AE), Zoocoria (ZO); Fitogeografia: Neotropical (NO), Tropical Americana (TA), Gondwânico (GO), Pantropical (PA), Cosmopolita (CO), Endêmica da Região (R), Tropical (TR).

\begin{tabular}{|c|c|c|c|c|c|c|}
\hline $\begin{array}{l}\text { Família / Espécie } \\
\text { 1-AMARANTHACEAE }\end{array}$ & Hábito & $\begin{array}{l}\text { Espectro } \\
\text { Biológico }\end{array}$ & $\begin{array}{l}\text { Síndrome de } \\
\text { dispersão }\end{array}$ & Fitogeografia & Seco & Chuvoso \\
\hline Alternanthera littoralis P.Beauv. & $\mathrm{E}$ & CR & $\mathrm{AU}$ & GO & $\mathrm{X}$ & \\
\hline $\begin{array}{l}\text { Blutaparon portulacoides (A.St.- } \\
\text { Hil.) Mears }\end{array}$ & $\mathrm{E}$ & CR & $\mathrm{AU}$ & $\mathrm{R}$ & & $\mathrm{X}$ \\
\hline \multicolumn{7}{|l|}{2 - ANACARDIACEAE } \\
\hline Schinus terebinthifolia Raddi & AV & FA & $\mathrm{ZO}$ & $\mathrm{CO}$ & $\mathrm{X}$ & $\mathrm{X}$ \\
\hline \multicolumn{7}{|l|}{3 - ASTERACEAE } \\
\hline Tridax procumbens (L.) L. & E & $\mathrm{CE}$ & $\mathrm{AE}$ & PA & $\mathrm{X}$ & $\mathrm{X}$ \\
\hline \multicolumn{7}{|l|}{4 - BORAGINACEAE } \\
\hline $\begin{array}{l}\text { Euploca polyphylla (Lehm.) J.I.M. } \\
\text { Melo \& Semir. }\end{array}$ & $\mathrm{E}$ & $\mathrm{CE}$ & $\mathrm{AU}$ & TA & $\mathrm{X}$ & $\mathrm{X}$ \\
\hline Heliotropium indicum L. & $\mathrm{E}$ & $\mathrm{CE}$ & $\mathrm{AU}$ & PA & $\mathrm{X}$ & $\mathrm{X}$ \\
\hline \multicolumn{7}{|l|}{5 - CACTACEAE } \\
\hline Cereus fernambucensis Lem. & E & $\mathrm{CS}$ & $\mathrm{ZO}$ & TA & $\mathrm{X}$ & $\mathrm{X}$ \\
\hline Opuntia stricta (Haw.) Haw. & $\mathrm{E}$ & $\mathrm{CS}$ & $\mathrm{ZO}$ & $\mathrm{CO}$ & $\mathrm{X}$ & $\mathrm{X}$ \\
\hline \multicolumn{7}{|l|}{6 - CHRYSOBALANACEAE } \\
\hline Chrysobalanus icaco L. & $\mathrm{AB}$ & $\mathrm{CE}$ & $\mathrm{ZO}$ & GO & $\mathrm{X}$ & $\mathrm{X}$ \\
\hline \multicolumn{7}{|l|}{7 - COMBRETACEAE } \\
\hline Terminalia catappa L. & AV & FA & $\mathrm{ZO}$ & PA & $\mathrm{X}$ & $\mathrm{X}$ \\
\hline \multicolumn{7}{|l|}{8 - COMMELINACEAE } \\
\hline Commelina erecta L. & E & $\mathrm{CE}$ & AU & GO & $\mathrm{X}$ & $\mathrm{X}$ \\
\hline \multicolumn{7}{|l|}{9 - CONVOLVULACEAE } \\
\hline Ipomoea imperati (Vahl) Griseb. & $\mathrm{E}$ & $\mathrm{HC}$ & AU & PA & $\mathrm{X}$ & $\mathrm{X}$ \\
\hline Ipomoea pes-caprae (L.) R. Br. & E & $\mathrm{HC}$ & $\mathrm{AU}$ & PA & $\mathrm{X}$ & $\mathrm{X}$ \\
\hline \multicolumn{7}{|l|}{10 - CYPERACEAE } \\
\hline $\begin{array}{l}\text { Cyperus appendiculatus (Brongn.) } \\
\text { Kunth }\end{array}$ & $\mathrm{E}$ & $\mathrm{CP}$ & $\mathrm{AU}$ & $\mathrm{R}$ & & $\mathrm{X}$ \\
\hline \multicolumn{7}{|l|}{11 - EUPHORBIACEAE } \\
\hline Cnidoscolus urens (L.) Arthur & E & $\mathrm{CE}$ & $\mathrm{AU}$ & TA & $\mathrm{X}$ & \\
\hline Euphorbia heterophylla L. & $\mathrm{E}$ & $\mathrm{CE}$ & $\mathrm{AU}$ & $\mathrm{CO}$ & $\mathrm{X}$ & $\mathrm{X}$ \\
\hline Euphorbia hirta L. & E & $\mathrm{CE}$ & $\mathrm{AU}$ & PA & & $\mathrm{X}$ \\
\hline Euphorbia hyssopifolia L. & $\mathrm{E}$ & $\mathrm{CE}$ & $\mathrm{AU}$ & $\mathrm{CO}$ & $\mathrm{X}$ & $\mathrm{X}$ \\
\hline Jatropha gossypiifolia L. & $\mathrm{AB}$ & $\mathrm{CE}$ & $\mathrm{AU}$ & PA & $\mathrm{X}$ & $\mathrm{X}$ \\
\hline Ricinus communis L. & $\mathrm{E}$ & $\mathrm{CE}$ & $\mathrm{AU}$ & $\mathrm{CO}$ & & $\mathrm{X}$ \\
\hline
\end{tabular}


(Continuação)

Tabela 1: Lista de espécies das espécies registradas na área de estudo da praia de Intermares - Cabedelo (PB-NE). Legenda - Hábito: Erva (E), Arbusto (AB), Árvore (AV); Espectro Biológico: Caméfito Reptante (CR), Caméfito Ereto (CE), Caméfito Suculento (CS), Fanerófito (FA), Hemicriptófito (HC), Cripitófito (CP), Liana (LI); Síndrome de dispersão: Autocoria (AU), Anemocoria (AE), Zoocoria (ZO); Fitogeografia: Neotropical (NO), Tropical Americana (TA), Gondwânico (GO), Pantropical (PA), Cosmopolita (CO), Endêmica da Região (R), Tropical (TR).

\begin{tabular}{|c|c|c|c|c|c|c|}
\hline Família / Espécie & Hábito & $\begin{array}{l}\text { Espectro } \\
\text { Biológico }\end{array}$ & $\begin{array}{l}\text { Síndrome de } \\
\text { dispersão }\end{array}$ & Fitogeografia & Seco & Chuvoso \\
\hline \multicolumn{7}{|l|}{12 - FABACEAE } \\
\hline Caesalpinia bonduc (L.) Roxb. & $\mathrm{AB}$ & $\mathrm{CE}$ & $\mathrm{AU}$ & PA & & $\mathrm{X}$ \\
\hline Canavalia rosea (Sw.) DC. & $\mathrm{E}$ & $\mathrm{HC}$ & $\mathrm{AU}$ & PA & $\mathrm{X}$ & $\mathrm{X}$ \\
\hline $\begin{array}{l}\text { Centrosema brasilianum (L.) } \\
\text { Benth. }\end{array}$ & E & LI & $\mathrm{AU}$ & NO & $\mathrm{X}$ & $\mathrm{X}$ \\
\hline Crotalaria retusa L. & E & $\mathrm{CE}$ & $\mathrm{AU}$ & PA & $\mathrm{X}$ & $\mathrm{X}$ \\
\hline $\begin{array}{l}\text { Macroptilium atropurpureum (DC.) } \\
\text { Urb. }\end{array}$ & E & $\mathrm{CE}$ & $\mathrm{AU}$ & PA & & \\
\hline Sophora tomentosa L. & $\mathrm{AB}$ & $\mathrm{CE}$ & $\mathrm{AU}$ & $\mathrm{CO}$ & $\mathrm{X}$ & $\mathrm{X}$ \\
\hline $\begin{array}{l}\text { Vigna halophila (Piper) Marechal \& } \\
\text { al. }\end{array}$ & E & LI & $\mathrm{AU}$ & $\mathrm{R}$ & & $\mathrm{X}$ \\
\hline \multicolumn{7}{|l|}{13 - GOODENIACEAE } \\
\hline Scaevola plumieri (L.) Vahl & E & $\mathrm{CE}$ & $\mathrm{ZO}$ & GO & $\mathrm{X}$ & $\mathrm{X}$ \\
\hline \multicolumn{7}{|l|}{14 - LOGANIACEAE } \\
\hline Spigelia anthelmia L. & E & $\mathrm{CE}$ & $\mathrm{AU}$ & PA & $\mathrm{X}$ & \\
\hline \multicolumn{7}{|l|}{15 - PASSIFLORACEAE } \\
\hline Passiflora foetida L. & E & $\mathrm{HC}$ & $\mathrm{ZO}$ & PA & $\mathrm{X}$ & $\mathrm{X}$ \\
\hline Turnera subulata Sm. & $\mathrm{E}$ & $\mathrm{CE}$ & $\mathrm{AU}$ & PA & $\mathrm{X}$ & $\mathrm{X}$ \\
\hline \multicolumn{7}{|l|}{16 - POACEAE } \\
\hline Cenchrus echinatus L. & $\mathrm{E}$ & $\mathrm{CP}$ & $\mathrm{AU}$ & $\mathrm{CO}$ & $\mathrm{X}$ & $\mathrm{X}$ \\
\hline $\begin{array}{l}\text { Dactyloctenium aegyptium (L.) } \\
\text { Willd. }\end{array}$ & E & $\mathrm{CP}$ & $\mathrm{AU}$ & PA & & \\
\hline \multicolumn{7}{|l|}{17 - PORTULACACEAE } \\
\hline Portulaca oleracea L. & E & CR & $\mathrm{AU}$ & $\mathrm{CO}$ & & $\mathrm{X}$ \\
\hline \multicolumn{7}{|l|}{18 - RUBIACEAE } \\
\hline Guettarda platypoda DC. & $\mathrm{AB}$ & $\mathrm{CE}$ & $\mathrm{ZO}$ & $\mathrm{R}$ & & $\mathrm{X}$ \\
\hline $\begin{array}{l}\text { Richardia grandiflora (Cham. \& } \\
\text { Schltdl.). Steud. }\end{array}$ & $\mathrm{E}$ & $\mathrm{CE}$ & $\mathrm{AU}$ & NO & $\mathrm{X}$ & $\mathrm{X}$ \\
\hline Spermacoce verticillata L. & E & $\mathrm{CE}$ & AU & PA & $\mathrm{X}$ & $\mathrm{X}$ \\
\hline \multicolumn{7}{|l|}{19 - SOLANACEAE } \\
\hline Solanum paniculatum L. & E & $\mathrm{CE}$ & $\mathrm{ZO}$ & $\mathrm{R}$ & & $\mathrm{X}$ \\
\hline \multicolumn{7}{|l|}{20 - ZYGOPHYLLACEAE } \\
\hline $\begin{array}{l}\text { Kallstroemia tribuloides (Mart.) } \\
\text { Steud. }\end{array}$ & E & $\mathrm{CR}$ & $\mathrm{AU}$ & TR & $\mathrm{X}$ & $\mathrm{X}$ \\
\hline
\end{tabular}

Figura 1: Riqueza de espécies encontradas, em relação ao seu hábito, na área de estudo na praia de Intermares - Cabedelo (PB-NE).

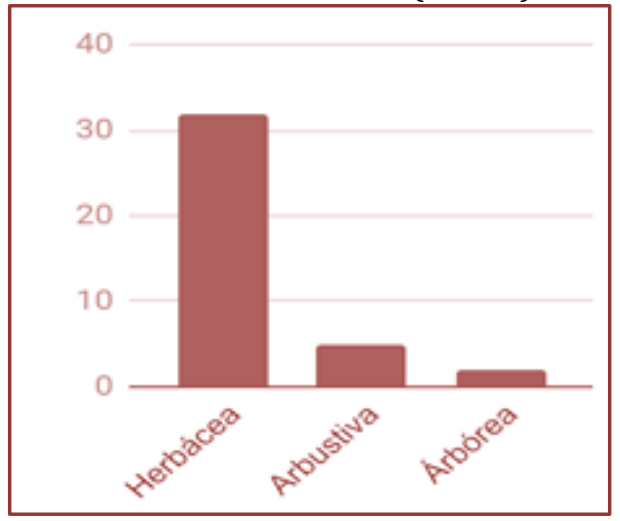


A predominância de ervas, acontece principalmente pelo fato de que algumas apresentam estratégias e mecanismos de adaptação a diferentes tipos de ecossistemas, ciclo de vida curto, com alta quantidade de produção de diásporos (Souza e Valio, 2001), em geral pequenos e leves, o que facilita a dispersão, além de contar com auxílio dos ventos alísios característicos de zonas praial em questão.

Reforçando essas características supracitadas, os resultados de síndrome de dispersão, indicaram que $71,8 \%$ das espécies são autocóricas (Figura 2), ou seja, não precisam de agentes externos para sua dispersão, pois mesmo não apresentando mecanismos morfológicos e funcionais para a dispersão, o vento colabora com esse processo local.

Figura 2: Síndrome de dispersão (segundo PIJL, 1972) das espécies registradas na área de estudo na praia de Intermares - Cabedelo (PB-NE).

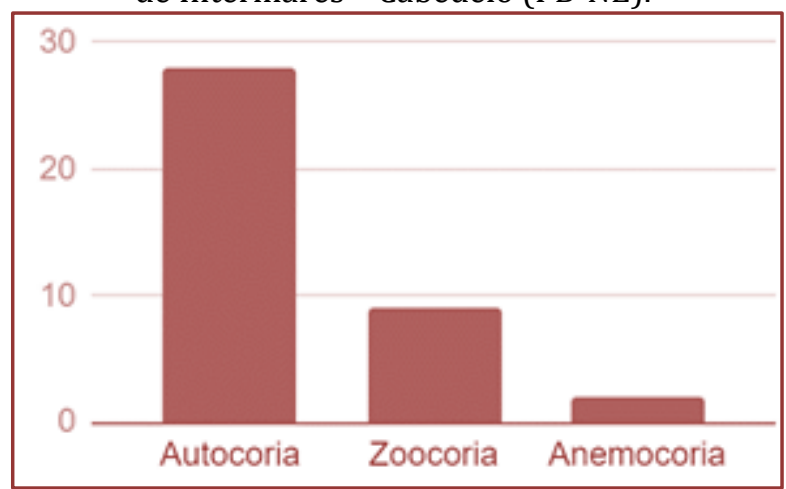

Destaca-se a grande quantidade de caméfitos (28 ssp.) entre os espécimes (Figura 3), que estão divididos em caméfitos eretos $(56,4 \%)$ caméfitos reptantes $(10,3 \%)$ e caméfitos suculentos $(5,1 \%)$. O número de caméfitos encontrada em região de dunas é geralmente alto, o que é comum em regiões inóspitas, submetidas a fortes ventos e secas Batalha \& Martins (2002).

Figura 3: Espectro biológico (segundo RAUNKIAER, 1934) das espécies registradas na área de estudo na praia de Intermares - Cabedelo (PB-NE).

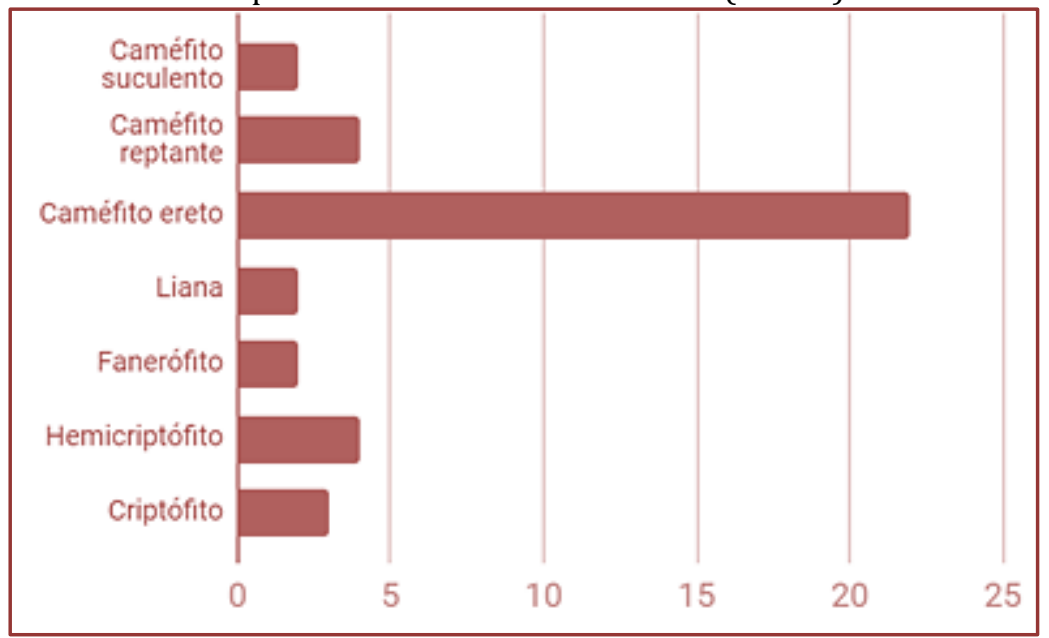

Foram ainda registradas algumas plantas endêmicas de outros biomas brasileiros, como por exemplo, da Caatinga, assim, é possível que isso aconteça majoritariamente porque a Restinga representa uma área de transição que pode agregar espécies muito comuns em outros ecossistemas. 
Também foi verificado o predomínio de ocorrências de plantas que são da província Pantropical (Figura 4) e também, um número considerável de espécies que se distribuem em outras províncias geográficas, demonstrando a variedade dos tipos de ocorrências mesmo sendo um ambiente inóspito e não favorável a uma larga biodiversidade da flora.

Figura 4: Padrões de distribuição geográfica das espécies encontradas na área de estudo na praia de Intermares - Cabedelo (PB-NE).

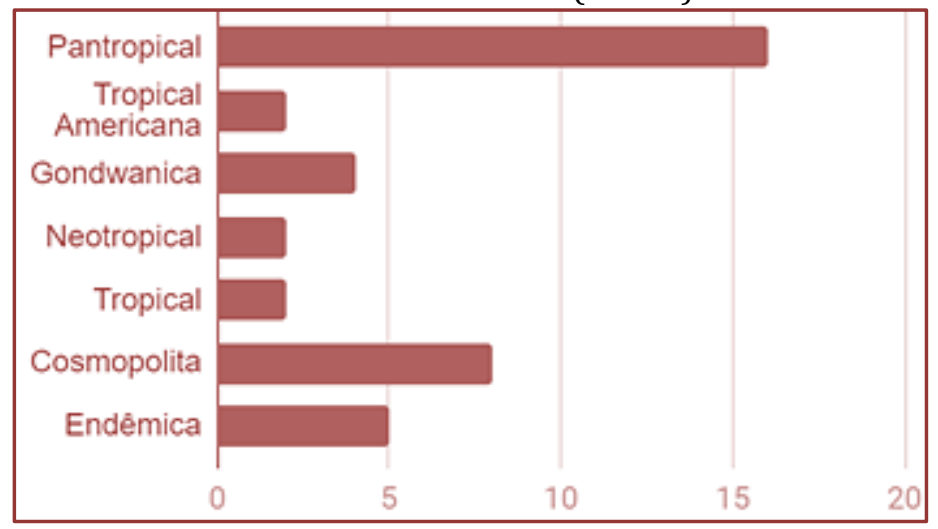

É indubitável ressaltar que Jatropha Gossypiifolia L., Terminalia catappa L., Ricinus Communis L. e Opuntia Stricta (Haw.) Haw. são espécies que não pertencem a flora nativa e foram introduzidas na área, ou seja, não são autóctones. Além disso, observa-se também que Tridax procumbens (L.) L. é uma nova ocorrência na Paraíba, de acordo com Lista de Espécies da Flora do Brasil (2019).

\section{CONSIDERAÇÕES FINAIS}

Apesar de ser uma área bem conhecida na região, poucos estudos da mesma abordagem foram realizados, e por ser bastante antropizada, é ainda mais necessário que já houvesse amostragem florística do local.

A flora pode ser considerada de pouca riqueza, quando comparada com outros biomas brasileiros, havendo poucas espécies endêmicas apenas deste ecossistema. Tal condição é relacionada à origem recente, da perspectiva geológica, dos locais de planície litorânea no Brasil, e, por conseguinte, ao pequeno tempo para que acontecesse a segregação de espécies novas (SILVA, 1990).

Estudos como este, podem auxiliar no manejo ambiental, gerenciamento e controle das espécies exóticas, para evitar o desaparecimento das espécies nativas, algumas dessas, já raras na área. Desse modo, para este trabalho foram consideradas espécies raras no local em estudo aquelas com distribuição fitogeográfica restrita, já quando encontradas ao longo de extensões quilométricas, foram consideradas de ampla distribuição.

Considera-se, portanto, que é necessário que ocorra o surgimento de um maior interesse às pesquisas nestas áreas, sobretudo para a seguridade do conhecimento e conservação da biodiversidade local.

\section{REFERÊNCIAS}

[1] APG IV (Angiosperm Phylogeny Group). An update of the Angiosperm Phylogeny Group classification for orders and families of flowering plants: APG IV.

[2] Botanical Journal of the Linnean Society, v. 181, 1-20. 2016.

[3] Barbosa, T.; Furrier, M.; Souza, A. S. Anthropogeomorphology of Cabedelo municipality - Paraíba state, Brazil. 13. 59-83, 2018.

[4] Batalha, M. A.; Martins, F. R. Life form spectra of Brazilian Cerrado sites. Flora 197: 452-460. 2004.

[5] Esteves, G.L. Contribuição ao conhecimento da vegetação da restinga de Maceió. Maceió, Secretaria de Planejamento do Estado de Alagoas. 1980. 
[6] Forzza, R. F. et al. Online [Internet]. Lista de espécies da flora do Brasil. Disponível em: <http://floradobrasil.jbrj.gov.br/reflora/PrincipalUC/PrincipalUC.do>. Acesso em: 01 ago. 2019.

[7] Fuhro, D.; Vargas, D.; Larocca, J. Levantamento florístico das espécies herbáceas, arbustivas e lianas da floresta de encosta da Ponta do Cego, Reserva Biológica do Lami (RBL), Porto Alegre, Rio Grande do Sul, Brasil. São Leopoldo: Instituto Anchietano de Pesquisas. N 56: 239-256, 2005

[8] Global Biodiversity Information Facility. Online [Internet]. Free and Open Access to Biodiversity Data. Disponível em: <23http:// www.gbif.org/>. Acesso em: 01 ago. 2019.

[9] Holzer, W.; Crichyno, J.; Pires, A.C. Sustentabilidade da urbanização em áreas de restinga: uma proposta de avaliação pós-ocupação. Paisagem Ambiente 19: 49-66. 2004.

[10] INPE - Instituto Nacional de Pesquisas Espaciais. Previsão do tempo para Cabedelo. Disponível em: <http://tempo.cptec.inpe.br/cidades/prevOceanica/1056>. Acesso em: 01 ago. 2019.

[11] Matias, L.Q.; Nunes, E.P. Levantamento florístico da área de Proteção Ambiental de Jericoacoara, Ceará. Acta Botanica Brasilica 15: 35-43. 2001

[12] Oliveira Filho, A.T.; Carvalho, D.A. Florística e fisionomia da vegetação no extremo norte do litoral da Paraíba. Revista Brasileira de Botânica 16: 115-130. 1993.

[13] PIJL, L. van der. Principles of dispersal in higher plants. 2 ed. Springer-Verlag, Berlin. 1972.

[14] Raunkiaer, C. The life forms of plants and statistical plant geography. Oxford: Claredon. 632p. 1934.

[15] Scarano, F. R. Structure, function and floristic relationships of plant communities in stressful habitats to the brazilian atlantic rainforest. Annals of Botany: v. 90, p. 517-524. 2002.

[16] Silva, S. M. Composição florística e fitossociologia de um trecho de floresta de restinga na Ilha do Mel, Município de Paranaguá, PR. Dissertação de Mestrado. Campinas. Universidade Estadual de Campinas. 146 p. 1990.

[17] Silva, S. M. Diagnósticos das restingas do Brasil. In: Workshop de Avaliação e Ações Prioritárias para Conservação da Biodiversidade da Zona Costeira e Marinha, Porto Seguro, BA. Anais: p. 30. 1999.

[18] Souza, R. P.; Valio, I. F. M. Seed size, seed germination and seedling survival of Brazilian tropical trees species differing successional status. Biotropica, v. 33, n. 3, p. 447-457, 2001.

[19] Suguio, K. et al. Paleoníveis do mar e paleolinhas de costa. In: Souza, C. R.;

[20] Suguio, K.; Oliveira, A. M. S.; de Oliveira, P. E. (Ed.). Quaternário do Brasil. Ribeirão Preto; Holos: Editora. p. 114-129. 2005.

[21] The Plant List. 2018. A working list of all plants species, Royal Botanic Gardens, Kew and Missouri Botanical Garden. Disponível em: <http://www.theplantlist.org/>. Acesso em: 01 ago. 2019.

[22] Veloso, H. P.; Rangel Filho, A. L. R.; Lima, J. C. A. 1991. Classificação da vegetação brasileira, adaptada a um sistema universal. Rio de Janeiro. IBGE - Derma. ISBN: 85-240-0384-7. 


\section{Capítulo 23}

De mentes atadas se condiciona o saber29: Eurocentrismo e colonialidade no ensino de história

\section{Cauê Almeida Galvão}

Resumo: Este artigo se propõe a debater os elementos constituídos como padrão oficial do ensino de História a partir da Base Nacional Curricular Comum (BNCC), em específico do currículo do sétimo e oitavo ano do ensino fundamental. Se parte do pressuposto da importância do processo de desconstrução eurocêntrica contido nos padrões de ensino, por se entender a necessidade de difusão dos elementos que vem sendo construídos a partir da discussão teórico-crítica da colonialidade do saber, poder e ser. Essa teoria, é fruto de uma luta de desconstrução epistêmica consolidada no seio da América Latina, e pode propiciar uma revolução teórica no sentido que imprimimos, entendemos e transpassamos em sala de aula como padrão normativo do que deve ser ensinado desde o padrão normativo da BNCC, assim como dos padrões eurocentrados aos quais a maior parte dos docentes do ensino básico foram formados. Por isso, esse artigo tem a intenção de refletir para avançar, entendendo a potência contida na construção teórica e propiciando elementos para fazerem parte do processo de ensino-aprendizagem da sala de aula por meio de questionamentos centrais e perspectivas distintas ao que se propõe a BNCC.

Palavras-chaves: Ensino de História; Colonialidade; BNCC.

${ }^{29}$ Se tomou no título uma referência à campanha de alfabetização emancipadora de Paulo Freire na cidade de Natal em 1961 denominada De pé no chão também se aprende a ler, fazendo referência a essa importante ação libertadora em contraponto ao ensino formal e suas limitações pelo dispositivo da colonialidade. 


\section{INTRODUÇÃO}

O contexto das definições de um saber histórico "oficial" foi determinante no processo de constituição da disciplina de História nas escolas básicas de ensino fundamental e médio e no processo de forjamento da identidade nacional e regional. Essa contextualização, antes pouco discutida, hoje é posta em xeque pelos pesquisadores e professores pelo avanço na compreensão divergente do modelo padrão eurocêntrico de como transmitir a memória e a história oficializadas no ensino de história.

Assim como, existem forças e frentes na sociedade sobretudo empresariais e vinculadas ao capitalismo comercial-educacional e aos organismos internacionais (Banco Mundial, OMC, think tanks) que articulam e defendem a manutenção desses mesmos pressupostos.

Por isso, a ideia desse artigo, é contextualizar as problemáticas articuladas pelo ensino de história envoltas nas construções didáticas pensadas na Base Nacional Comum Curricular (BNCC) para o Ensino Infantil e Fundamental - Anos iniciais e Anos finais, homologado pelo Ministério da Educação em dezembro de 2017, e instituído pela resolução do Conselho Nacional de Educação (CNE) CNE/CP no2, de 22 de dezembro de 2017.

Para uma compreensão mais bem apurada, escolheu-se para análise e interpretação, os currículos do 7ํㅡ e 8 o ano, por esses apontarem alguns elementos necessariamente essenciais, para uma reinterpretação do ensino de história afora da perspectiva eurocentrada e colonial do saber.

Nesse sentido, segundo o documento da BNCC, "no 7o ano, as conexões entre Europa, América e África são ampliadas. São debatidos aspectos políticos, sociais, econômicos e culturais ocorridos a partir do final do século XV até o final do século XVIII". E ainda, que, "no 8o ano, o tema é o século XIX e a conformação histórica do mundo contemporâneo. Destacam-se os múltiplos processos que desencadearam as independências nas Américas, com ênfase no processo brasileiro e seus desdobramentos". (BRASIL, 2017, p.418)

Esses elementos pautados na BNCC, são esmiuçados em partes fragmentadas, que voltaremos no decorrer do texto a demonstrar, por meio da correlação com a crítica que se apresenta.

A crítica que pautaremos aqui, é a necessidade de estar contido no ensino de história a compreensão por parte dos estudantes do processo de colonialidade do poder, saber, ser, de gênero, da natureza, jurídica, pedagógica, etc, para favorecer a possibilidade de ruptura com os elementos castradores da autonomia do pensar e do agir dos sujeitos latino-americanos e consequentemente dos brasileiros.

Nesse sentido, a importância desde o início do processo educativo formal de ter em conta que a identidade dos povos latino-americanos foi forjada e cooptada ao elemento do europeu como sujeito superior e central, fortalece a possibilidade de compreensão do que aponta Aníbal Quijano (2005, p.2), que "a ideia de raça foi uma maneira de outorgar legitimidade às relações de dominação impostas pela conquista".

Assim como compreender como infere Walter Mignolo (2007, p.28) que "América nunca foi um continente que tivesse que se descobrir, mas sim uma invenção forjada durante o processo da história colonial europeia e a consolidação e expansão das ideias e instituições ocidentais."

Acredita-se que somente por meio desse entendimento pelos estudantes das invenções históricas europeias e dos elementos legitimadores dela, é possível romper com essas estruturas e instituições e organizar os saberes desde a perspectiva geocultural latinoamericana.

\section{A COLONIALIDADE DO PODER, SABER E SER NA INTERPRETAÇ̃̃O HISTÓRICA}

Destarte, para que o ensino de história não eurocentrado possa ser organizado e pautado é necessário,

Considerar o sistema mundo como moderno-colonial e deixar que o espaço fale haja vista que é o espaço-mundo como um todo que se conforma, e não o mundo visto como se fosse estágios distintos da Europa e, assim, um evolucionismo em que os lugares e as regiões do mundo são silenciados. (QUENTAL, 2012, p.18)

A partir dessa consideração, os elementos constitutivos do modus operandi da educação eurocentrada pode ser questionado e até mesmo desconstruído, pois, quando entendemos a potência no ensino fundamental de interpretar a realidade social latino-americana desde a perspectiva decolonial, propiciamos a compreensão de que "a colonialidade, então, consiste em revelar a lógica encoberta que 
impõe o controle, a dominação e a exploração, uma lógica oculta por trás do discurso da salvação, o progresso, a modernização e o bem comum." (MIGNOLO, 2007, p.32)

A transformação dos ambientes educacionais e dos conteúdos disciplinares corroboram para que "o vínculo educação e decolonialidade, seja um contribuidor da construção de um sentido amplo de pertencimento pedagógico, mais além da atenção às necessidades imediatas do mercado profissional ou da transmissão de determinado projeto de nação." (PARRA, 2015)

Romper com esse padrão de método de ensino, requer compreender que a estrutura consolidada no seio da ciência moderna-colonial, foi forjado em primeira instância pelo fator religioso que reverberou a divisão binária de mundo, e produziu diversos racismos/sexismos-genocídios/epistemicídios como bem rememora Ramón Grosfoguel ao sinalizar para quatro determinantes momentos históricos ao longo do século XVI,

1. contra os muçulmanos e judeus na conquista de Al-Andalus em nome da "pureza do sangue"; 2. contra os povos indígenas do continente americano, primeiro, e, depois, contra os aborígenes na Ásia; 3. contra africanos aprisionados em seu território e, posteriormente, escravizados no continente americano; e 4. contra as mulheres que praticavam e transmitiam o conhecimento indo-europeu na Europa, que foram queimadas vivas sob a acusação de serem bruxas. (GROSFOGUEL, 2016)

Essa consolidação aos moldes escolásticos tomou proporções ainda maiores com a chegada dos europeus na zona latinoamericana e sua expansão econômica através da espoliação de recursos e exploração de corpos. Bem como, do posterior rebaixamento da região ibérica pela ciência moderna pautada sobre a ideia de Kant que demarca a linha divisória europeia a partir do século XVIII e consolida o motor do saber da humanidade na esfera de cinco países.

A visão antropológica racista de Kant, posicionando os Pirineus como linha divisora da Europa, que separava a irracionalidade da racionalidade, seguiu as modificações geopolíticas que tomaram corpo no século XVI. Kant aplicou na Península Ibérica, no século XVIII, a mesma visão racista aplicada ao resto do mundo no século XVI. Isto é importante para que possamos entender por que os portugueses e os espanhóis estão de fora do cânone das universidades ocidentais nos dias de hoje, a despeito de terem estado no centro do sistemamundial, criado após 1492. Desde o fim do século XVIII, apenas homens de cinco países (França, Alemanha, Inglaterra, Itália e Estados Unidos) monopolizam o cânone nas universidades ocidentalizadas. (GROSFOGUEL, 2016)

Ao estar fora dos cânones das universidades ocidentais, os países ibéricos e a zona latinoamericana, foram engendradas como células pertencentes ao imaginário inventado do Ocidente, assim sendo, um apêndice da história sem grandes importâncias.

O fator negacionista do pensamento eurocêntrico-ocidentalocêntrico é um produto pré-pronto, uma espécie de fast-food do saber que já vem pronto, só nos resta alimentar-se sem questionar o que contém nele.

Esse fato, é corroborado ainda pelo que o autor acima citado põe em relevo de que o primeiro genocídioepistemicídio perpetrado contra os muçulmanos e judeus na conquista de Al-Andalus ainda não se questionava a humanidade dos sujeitos, pois,

A humanidade das vítimas não era posta em julgamento. 0 que se colocava em dúvida era a identidade ideológica e teológica dos sujeitos sociais. A classificação social usada na época tinha relação com uma questão teológica de ter o "Deus equivocado" ou a "religião errada" para dividir a sociedade em grupos religiosos. (IDEM, 2016)

Entre a conquista de Al-Andalus e da América ocorreram algumas vinculações entre os elementos genocidas-epistemicidas, pois "Os métodos de colonização e dominação utilizados em Al-Andalus foram transportados para as Américas (Garrido Aranda, 1980)". Assim como, o epistemicídio ocorreu em AlAndalus pela queima de bibliotecas, "o mesmo aconteceu com os códices indígenas - a parte escrita da prática utilizada pelos ameríndios na busca pelo conhecimento". (GROSFOGUEL, 2016)

Porém, como aponta Nelson Maldonado Torres, 
[...]as coordenadas conceituais que definiram a "luta pelo império" e as formas de classificação do século IV e dos séculos seguintes, antecessores da "descoberta" e da conquista das Américas, mudaram drasticamente no século XVI. A relação entre a religião e o império estaria no centro de uma transformação dramática de um sistema de poder baseado em diferenças religiosas para outro baseado em diferenças raciais. É justamente por essa razão que na Modernidade a episteme dominante não seria mais definida pela tensão e pela colaboração mútuas entre a ideia de religião e a visão imperialista do mundo conhecido, mas, mais precisamente, através de uma relação dinâmica entre o império, a religião e a raça. (MALDONADO-TORRES, grifo nosso, 2008)

Essa transformação dramática que aponta o autor do sistema de poder a partir de então baseado na raça, vinha vinculado aos entendimentos necessários para o poder religioso estruturar as fórmulas de espoliação e extermínio dos indígenas com o argumento dos povos "sem religião". Sobre essa questão cabe destacar para uma melhor compreensão que,

0 que estava sendo questionado era a "teologia" do outro. Tudo foi radicalmente modificado em 1492, com a conquista das Américas e a caracterização de povos indígenas por Colombo como "povos sem religião". Como dissemos, uma leitura anacrônica desta frase pode fazer parecer que Colombo se referia a "povos ateus". Mas, no imaginário cristão da época, não ter uma religião equivalia a não ter uma alma, isto é, ser expulso da esfera do humano. (GROSFOGUEL, 2016)

Ao ser expulso da esfera do humano, e ter castrada sua humanidade, os povos latino-americanos foram o fator determinante da expansão do ideal eurocentrista e para a fundamentação do sistema-mundo moderno-colonial, que será aperfeiçoado com as bases do capitalismo industrial e com a fundamentação racista que Kant organizará na cientificidade como apontado acima.

É nesse sentido que o autor acima citado assevera que "O racismo de Estado não é um fenômeno posterior ao século XVIII, emergiu da conquista das Américas no século XVI". E esse racismo de Estado será aperfeiçoado no decorrer dos séculos através da colonialidade do poder, do ser e do saber, forjando movimentos de independência que foram produzidos e pensados aos moldes europeus, e a ascensão do Estado-nação como elemento globalizador do sistema-mundo capitalista e controlador de corpos, mentes e ações limitadoras ao cerco possível do padrão eurocentrado.

Esse cerco é diretamente refletido no padrão educacional, que tem seu princípio também no elemento da conquista com a obrigação dos indígenas ao catecismo jesuítico, passando pelas estruturas do Estadonacional moderno-colonial e da sistematização do que se deve e pode aprender dentro do padrão normativo eurocêntrico.

É esse padrão, rearticulado na BNCC de 2017, que faremos uma análise crítica para tentar compreender os elementos de sustentação do padrão eurocentrado do ensino de história como disciplina escolar.

\section{PADRÃO MODERNO-COLONIAL NO ENSINO DE HISTÓRIA NA BNCC DE 2017}

A BNCC do 70 ano está organizada em 4 Unidades Temáticas com 11 Objetos de Conhecimento (1 - 0 mundo moderno e a conexão entre sociedades africanas americanas e europeias - A construção da ideia de modernidade e seus impactos na concepção de História/ A ideia de "Novo Mundo" ante o Mundo Antigo: permanências e rupturas de saberes e práticas na emergência do mundo moderno/ Saberes dos povos africanos e pré-colombianos expressos na cultura material e imaterial - 2 - Humanismos, Renascimentos e o Novo Mundo- Humanismos: uma nova visão de ser humano e de mundo/ Renascimentos artísticos e culturais/ Reformas religiosas: a cristandade fragmentada/ As descobertas científicas e a expansão marítima - 3 - A organização do poder e as dinâmicas do mundo colonial americano - A formação e o funcionamento das monarquias europeias: a lógica da centralização política e os conflitos na Europa/ A conquista da América e as formas de organização política dos indígenas e europeus: conflitos, dominação e conciliação/ A estruturação dos vice-reinos nas Américas/ Resistências indígenas, invasões e expansão na América portuguesa - 4 - Lógicas comerciais e mercantis da modernidade - As lógicas mercantis e o domínio europeu sobre os mares e o contraponto Oriental/ As lógicas internas das sociedades africanas/ As formas de organização das sociedades ameríndias/ A escravidão moderna e o tráfico de escravizados/ A emergência do capitalismo -) 
Assim como 17 habilidades como método de ensino dos 11 objetos de conhecimento. Sendo elas (EF07HI01) Explicar o significado de "modernidade" e suas lógicas de inclusão e exclusão, com base em uma concepção europeia; (EF07HI02) Identificar conexões e interações entre as sociedades do Novo Mundo, da Europa, da África e da Ásia no contexto das navegações e indicar a complexidade e as interações que ocorrem nos Oceanos Atlântico, Índico e Pacífico. (EF07HI03) Identificar aspectos e processos específicos das sociedades africanas e americanas antes da chegada dos europeus, com destaque para as formas de organização social e o desenvolvimento de saberes e técnicas. (EF07HI04) Identificar as principais características dos Humanismos e dos Renascimentos e analisar seus significados. (EF07HI05) Identificar e relacionar as vinculações entre as reformas religiosas e os processos culturais e sociais do período moderno na Europa e na América. (EF07HI06) Comparar as navegações no Atlântico e no Pacífico entre os séculos XIV e XVI. (EF07HI07) Descrever os processos de formação e consolidação das monarquias e suas principais características com vistas à compreensão das razões da centralização política. (EF07HI08) Descrever as formas de organização das sociedades americanas no tempo da conquista com vistas à compreensão dos mecanismos de alianças, confrontos e resistências. (EF07HI09) Analisar os diferentes impactos da conquista europeia da América para as populações ameríndias e identificar as formas de resistência. (EF07HI10) Analisar, com base em documentos históricos, diferentes interpretações sobre as dinâmicas das sociedades americanas no período colonial. (EF07HI11) Analisar a formação histórico-geográfica do território da América portuguesa por meio de mapas históricos. (EF07HI12) Identificar a distribuição territorial da população brasileira em diferentes épocas, considerando a diversidade étnico-racial e étnico-cultural (indígena, africana, europeia e asiática). (EF07HI13) Caracterizar a ação dos europeus e suas lógicas mercantis visando ao domínio no mundo atlântico. (EF07HI14) Descrever as dinâmicas comerciais das sociedades americanas e africanas e analisar suas interações com outras sociedades do Ocidente e do Oriente. (EF07HI15) Discutir o conceito de escravidão moderna e suas distinções em relação ao escravismo antigo e à servidão medieval. (EF07HI16) Analisar os mecanismos e as dinâmicas de comércio de escravizados em suas diferentes fases, identificando os agentes responsáveis pelo tráfico e as regiões e zonas africanas de procedência dos escravizados. (EF07HI17) Discutir as razões da passagem do mercantilismo para o capitalismo.

Já na primeira habilidade surge a proposição de explicar o significado de "modernidade", com base em uma concepção europeia. A inferência do documento como um modelo já castra logo de início apresentar uma perspectiva que destoe do pensar eurocêntrico. Além disso, como essa habilidade está na Unidade Temática que expressa o mundo "moderno" e a conexão com as outras sociedades, subentende-se como apontamos acima, que as outras sociedades não-modernas, são apêndices do processo de explicação, sendo tidas como inferiores no processo histórico de consolidação da história "oficial" como disciplina escolar.

Na segunda Unidade Temática onde entra em debate o Humanismo, Renascimentos e o "Novo Mundo" a proposta passa então para a fundamentação do humanismo eurocêntrico pautado sobre os ideais do "ego, cogito" (penso, logo existo) de Descartes, evidentemente, sem levantar o debate proposto por Enrique Dussel (2005) de que "o "penso, logo existo" de Descartes é precedido por 150 anos de "conquisto, logo existo". O Ego conquiro é a condição de existência do Ego cogito de Descartes. Pois, no primeiro momento se nega uma abordagem não-europeia. Nem tampouco é possível se pensar que,

O que conecta o "conquisto, logo existo" (Ego conquiro) com o idolátrico "penso, logo existo" (Ego cogito) é o racismo/sexismo epistêmico produzido pelo "extermino, logo existo" (Ego extermino). É a lógica conjunta do genocídio/epistemicídio que serve de mediação entre o "conquisto" e o racismo/sexismo epistêmico do "penso" como novo fundamento do conhecimento do mundo moderno e colonial. (GROSFOGUEL, 2016)

Na terceira Unidade Temática, entra em discussão A organização do poder e as dinâmicas do mundo colonial americano. Nessa unidade na primeira habilidade se propõe entender as razões para a centralização do poder dos sistemas monárquicos, porém, como seria possível compreender essas razões sem levar em consideração os elementos negados anteriormente nas unidades anteriores?

Em nenhum momento nessa unidade se discute o contexto de escravidão e os processos de controle interno e externo que ocorreram desde a metrópole, bem como, não se toca no aspecto da exploração excessiva da natureza por parte das colônias, feitos a partir do sistema de trabalho escravo.

Ao apontar nessa unidade para o debate das resistências, alianças e confrontos, qual seria a base dos estudantes para interpretar essas resistências e confrontos se o modelo padrão é a concepção histórica europeia? 0 contexto de aliança nesse sentido parece dominar o debate como forma de interpretar a 
história desde a importância dos europeus no processo de conquista para um avanço civilizatório da zona latinoamericana, fortalecendo até a atualidade os complexos de vira-lata de inferiorização de si mesmo, perpetrados desde 1492 .

Na quarta Unidade Temática onde entra em discussão as Lógicas comerciais e mercantis da modernidade, surge a ideia de caracterizar as lógicas mercantis europeias como elemento de domínio do Atlântico, sem, entretanto, levar em consideração os extermínios perpetrados para que essa veia mercantil pudesse ser recontada na atualidade como elemento positivo.

Também aparece, apenas nessa unidade, a discussão do conceito de escravidão, porém, com as habilidades metodológicas de explicar a distinção entre escravismo antigo e servidão medieval. Nesse aspecto, cabe recordar, que como apontamos acima, a chegada a América irá ressignificar os processos de entendimento do humano e não-humano, o que favorecerá a estruturação de um novo sistema de poder, que inclui a economia e a relação de trabalho, como aponta muito bem Immanuel Wallerstein (1990) no seu conceito de sistema-mundo moderno.

Além disso, se imprime um discurso na última habilidade de uma história em série, ao propor a discussão da passagem do mercantilismo para o capitalismo. Nesse ponto, se anuvia debates incessantes que partem de pressupostos diferentes e questionam esse modelo de história-régua, como a ideia de Wallerstein de que o capitalismo se inicia com a chegada europeia em 1492 na América, e que esse fator, será o fator determinante desse sistema econômico dominante, que terá no mercantilismo uma fase de capitalismo acumulativo, o que possibilitou o avanço da industrialização no século XVIII.

Como é visível, os dispositivos reverberados como modelo comum curricular da BNCC para o 70 ano são preenchidos pelo elemento eurocêntrico de negação da colonialidade e valorização excessiva da modernidade e do europeu. Não alcançando chegar à conclusão do pensamento da colonialidade de que só é possível a modernidade por conta dos dispositivos da colonialidade.

Passamos então a análise da BNCC para o 8o ano que está organizada em 4 Unidades Temáticas com 22 Objetos de Conhecimento (1- 0 mundo contemporâneo: o Antigo Regime em crise. - A questão do iluminismo e da ilustração/ As revoluções inglesas e os princípios do liberalismo/ Revolução Industrial e seus impactos na produção e circulação de povos, produtos e culturas/ Revolução Francesa e seus desdobramentos/ Rebeliões na América portuguesa: A conjuração Mineira e Baiana -. 2 - Os processos de independência nas Américas. - Independência dos Estados Unidos da América/ Independências na América espanhola/ Os caminhos até a independência do Brasil/ A tutela da população indígena, a escravidão dos negros e a tutela dos egressos da escravidão - . 3 - O Brasil no século XIX. - Brasil: Primeiro Reinado/ O Período Regencial e as contestações ao poder central/ O Brasil do Segundo Reinado: política e economia 0 escravismo no Brasil do século XIX: plantations e revoltas de escravizados, abolicionismo e políticas migratórias no Brasil Imperial/ Políticas de extermínio do indígena durante o Império/ A produção do imaginário nacional brasileiro: cultura popular, representações visuais, letras e o Romantismo no Brasil -. 4 - Configurações do mundo no século XIX. - Nacionalismo, revoluções e as novas nações europeias/ Uma nova ordem econômica: as demandas do capitalismo industrial e o lugar das economias africanas e asiáticas nas dinâmicas globais/ Os Estados Unidos da América e a América Latina no século XIX/ O imperialismo europeu e a partilha da África e da Ásia/ Pensamento e cultura no século XIX: darwinismo e racismo/ 0 discurso civilizatório nas Américas, o silenciamento dos saberes indígenas e as formas de integração e destruição de comunidades e povos indígenas/ A resistência dos povos e comunidades indígenas diante da ofensiva civilizatória -

Como também 27 habilidades como método de ensino para os 22 objetos de conhecimento. Sendo elas (EF08HI01) Identificar os principais aspectos conceituais do iluminismo e do liberalismo e discutir a relação entre eles e a organização do mundo contemporâneo. (EF08HI02) Identificar as particularidades político-sociais da Inglaterra do século XVII e analisar os desdobramentos posteriores à Revolução Gloriosa. (EF08HI03) Analisar os impactos da Revolução Industrial na produção e circulação de povos, produtos e culturas. (EF08HI04) Identificar e relacionar os processos da Revolução Francesa e seus desdobramentos na Europa e no mundo. (EF08HI05) Explicar os movimentos e as rebeliões da América portuguesa, articulando as temáticas locais e suas interfaces com processos ocorridos na Europa e nas Américas. (EF08HI06) Aplicar os conceitos de Estado, nação, território, governo e país para o entendimento de conflitos e tensões. (EF08HI07) Identificar e contextualizar as especificidades dos diversos processos de independência nas Américas, seus aspectos populacionais e suas conformações territoriais. (EF08HI08) Conhecer o ideário dos líderes dos movimentos independentistas e seu papel nas revoluções que levaram à independência das colônias hispano-americanas. (EF08HI09) Conhecer as características e os principais pensadores do Pan-americanismo. (EF08HI10) Identificar a Revolução de 
São Domingo como evento singular e desdobramento da Revolução Francesa e avaliar suas implicações. (EF08HI11) Identificar e explicar os protagonismos e a atuação de diferentes grupos sociais e étnicos nas lutas de independência no Brasil, na América espanhola e no Haiti. (EF08HI12) Caracterizar a organização política e social no Brasil desde a chegada da Corte portuguesa, em 1808, até 1822 e seus desdobramentos para a história política brasileira. (EF08HI13) Analisar o processo de independência em diferentes países latino-americanos e comparar as formas de governo neles adotadas. (EF08HI14) Discutir a noção da tutela dos grupos indígenas e a participação dos negros na sociedade brasileira do final do período colonial, identificando permanências na forma de preconceitos, estereótipos e violências sobre as populações indígenas e negras no Brasil e nas Américas. (EF08HI15) Identificar e analisar o equilíbrio das forças e os sujeitos envolvidos nas disputas políticas durante o Primeiro e o Segundo Reinado. (EF08HI16) Identificar, comparar e analisar a diversidade política, social e regional nas rebeliões e nos movimentos contestatórios ao poder centralizado. (EF08HI17) Relacionar as transformações territoriais, em razão de questões de fronteiras, com as tensões e conflitos durante o Império. (EF08HI18) Identificar as questões internas e externas sobre a atuação do Brasil na Guerra do Paraguai e discutir diferentes versões sobre o conflito. (EF08HI19) Formular questionamentos sobre o legado da escravidão nas Américas, com base na seleção e consulta de fontes de diferentes naturezas. (EF08HI20) Identificar e relacionar aspectos das estruturas sociais da atualidade com os legados da escravidão no Brasil e discutir a importância de ações afirmativas. (EF08HI21) Identificar e analisar as políticas oficiais com relação ao indígena durante o Império. (EF08HI22) Discutir o papel das culturas letradas, não letradas e das artes na produção das identidades no Brasil do século XIX. (EF08HI23) Estabelecer relações causais entre as ideologias raciais e o determinismo no contexto do imperialismo europeu e seus impactos na África e na Ásia.

(EF08HI24) Reconhecer os principais produtos, utilizados pelos europeus, procedentes do continente africano durante o imperialismo e analisar os impactos sobre as comunidades locais na forma de organização e exploração econômica. (EF08HI25) Caracterizar e contextualizar aspectos das relações entre os Estados Unidos da América e a América Latina no século XIX. (EF08HI26) Identificar e contextualizar o protagonismo das populações locais na resistência ao imperialismo na África e Ásia. (EF08HI27) Identificar as tensões e os significados dos discursos civilizatórios, avaliando seus impactos negativos para os povos indígenas originários e as populações negras nas Américas.

Na primeira unidade temática, denominada 0 mundo contemporâneo: o Antigo regime em crise, a BNCC coloca como método de explicação a apresentação do Iluminismo e do Liberalismo como elemento fundante dessa "modernidade", porém, como apontamos acima, essa estrutura de invenção da modernidade tem sua origem no século XVI, mais precisamente desde 1492. 0 Iluminismo e o Liberalismo têm seu fator de importância histórica, porém, só foram possíveis por conta da estrutura consolidada durante dois séculos anteriores que propiciaram esses movimentos, e não a partir e desde a Europa pela Europa, como sempre nos é contado.

Além disso, a primeira unidade temática traz ainda uma parte para explicar a Revolução Gloriosa inglesa e a Revolução Industrial, como se esses dois elementos fossem a explicação chave de consideração da entrada da humanidade ocidentalocêntrica na modernidade. Assim como a Revolução Francesa, porém, no caso específico da Revolução Francesa, os aspectos apropriados desse movimento histórico pelos movimentos independentistas latino-americanos construídos pelas elites criollas e luso-brasileiras, produziram as estruturas do Estado-nação como elemento demarcador das classes sociais em uma zona espoliada por séculos e com uma desigualdade estrutural crônica. Os louros dessa Revolução transpassados à zona latinoamericana foram estruturados para uma manutenção dos privilégios dessas classes dominantes e o controle das classes baixas desde as esferas jurídica, política e governamental.

A cópia posta em prática na região, não levou em consideração a reforma agrária por exemplo, que é um fator determinante para a redução das desigualdades, e isso fortaleceu as estruturas coronelistas e clientelistas, já que como aponta Octávio Ianni (2004), o que ocorreu no Brasil foi uma modernização conservadora, ou seja, uma mudança de sistema-regime desde as elites, sem levar em conta a população. Uma espécie de República sem povo.

Ainda na primeira unidade temática, se traz ao debate a Inconfidência Mineira e a Revolta dos Alfaiates, denominadas como conjurações, que no dicionário pode ser entendida como conspiração. 0 movimento da Inconfidência foi um movimento das elites e dos militares contra a coroa, e exatamente por ser constituído por elementos da elite, ficou marcado na história "oficial" do Brasil. Já a Revolta dos Alfaiates, foi um movimento popular emancipacionista, que contou com a participação de ex-escravos e escravos e tinha como uma das bandeiras de luta o fim do sistema escravocrata, e tem sua importância reduzida no contexto do pensamento social nacional. 
Assim como também são deixados de lado os movimentos confederados e revoltosos de indígenas como a Confederação dos Cariris (1683-1713) ocorrida na então capitania do Pernambuco que engloba atualmente os estados do Rio Grande do Norte, Paraíba e Ceará, e que será denominada pela historiografia oficial como Revolta dos Bárbaros, palavra inclusive, bastante sugestiva para explicitar os indesejáveis para o sistema. Tinha como alvo principal o avanço dos sesmeiros, que se apossavam das terras para pecuária e escravizava indígenas, além do recurso da violência sexual e do extermínio. Assim como, a Revolta de Mandu Ladino (1712-1719) ocorrida no Piauí e estendida ao Maranhão e Ceará, e que teve como alvo os fazendeiros mandonistas que escravizavam os indígenas e os aldeamentos construídos pelos jesuítas forçosamente.

Esses movimentos, por mais que tenham ocorrido algum tempo antes dos citados pela BNCC, representam a consolidação dos indígenas contra a repressão sempre existente na colônia brasileira, e a questão já levantada acima da apropriação das terras como elemento condicionador do poder das elites locais e regionais, que favorecerá então, os movimentos independentistas nacionais ao final do século XVIII.

Por serem invisibilizados, a historiografia faz parecer que tudo ocorria em paz no processo de colonização, até a ascensão dos movimentos que a BNCC propõe, negando dessa forma, as constantes lutas e conflitos pela terra e contra a violência e extermínio indígena, assim como sua escravização forçada. Nesse sentido, seria interessante analisar também esses movimentos revoltosos indígenas como elemento aglutinador de possibilidades de levantes populares, exatamente em um momento de consolidação das elites por meio da apropriação dos territórios com as sesmarias. Esse elemento é importantíssimo para entender que "o novo enquadramento consiste em pesquisar o problema indígena no problema da terra". (MARIÁTEGUI, 1975, p.28)

Passando para a Unidade Temática denominada Os processos de independência nas Américas, surgem elementos que poderíamos considerar mais interessantes para explicar a resistência à conquista desde uma perspectiva menos eurocentrada quando se propõe a identificação e contextualização dos processos de Independência das Américas, sem necessariamente mencionar quais. Um aspecto positivo a se considerar nessa unidade é a definição para se explicar a Revolução Haitiana, que foi a primeira região independente na zona latinoamericana, e protagonizou uma revolução de escravos. Até mesmo por esse fator, até hoje é reduzida sua importância em relação a Revolução Estadunidense e Francesa.

Dentro das habilidades surge também a recomendação de caracterizar o período de 1808-1822, ou seja, da chegada da coroa portuguesa fugida da Europa para a Colônia, até a Independência do Brasil. 0 que é interessante, é que o Brasil, saiu de uma monarquia para um império, e diferente dos irmãos latinoamericanos, não produziu uma república como modelo posterior a sua independência. Esse elemento é importante para compreendermos por exemplo, o período do Império como o momento histórico onde houve mais revoltas e insurreições populares. Entre essas insurreições e revoltas se destaca a Confederação do Equador (1823-1824), Noite das Garrafadas (1831), Federação dos Guanais (1832), Revolta dos Malês (1835), Cabanagem (1835-1840), Balaiada (1838-1841), Revolta das Mulheres (1875), Revolta do Quebra-Quilos (1872-1877), entre diversos outras.

Esses levantes ocorreram por diversos motivos, mas representam incondicionalmente a crise de controle do poder central, exigindo então, a estruturação e o fortalecimento da figura dos coronéis locais e regionais. Esse será um fator marcante do processo de constituição da República, e representará a continuidade do poder central exercido pelas elites locais com aval do poder central que reorganizará sua estrutura de controle e poder, além de consolidar as relações de privilégios entre as classes abastadas e os pobres.

O objeto de conhecimento separado no final dessa unidade temática, é denominado como A tutela da população indígena, a escravidão dos negros e a tutela dos egressos da escravidão. Nesse objeto, se propõe discutir a tutela indígena e a participação dos negros na sociedade brasileira, identificando permanências de preconceitos, estereótipos e violências.

Nos faz necessário então, compreender que a participação dos negros na sociedade brasileira foi a negação da participação deles nessa "nova sociedade", e que sua importância surge das suas lutas e levantes contra o processo de escravização. Se analisamos o primeiro código criminal brasileiro de 1830, podemos encontrar as diferenças de tratamento ao negro em relação ao branco, sobretudo nas definições de 
castigos corporais e dos valores das multas, assim como na instituição das galés, que terá o sistema de trabalho forçado e o uso de grilhões, uma espécie de continuidade do sistema escravocrata ${ }^{30}$.

Como também, os levantes indígenas e suas resistências representaram a sua sobrevivência no processo histórico, mesmo que até a atualidade sendo entendidos como entes jurídicos tutelados pelo Estado.

Passando a outra Unidade Temática denominada O Brasil no século XIX, se coloca em debate os levantes durante o Império brasileiro, sem necessariamente citar algum desses movimentos, como fizemos acima nesse texto, e traz ao debate mesmo que timidamente a Lei de Terras, que representou a consolidação da usurpação territorial feita pelas sesmarias.

Traz também a Guerra do Paraguai (1865-1870) intencionando debater as versões sobre o conflito, entretanto, não se menciona o impacto dessa guerra ao país irmão latinoamericano, e o extermínio concebido por Brasil, Argentina e Uruguai ao povo paraguaio. Caberia então, ao professor expressar esses elementos da história contada pelos "opositores"? Todos fariam essa análise? Seria possível com o saber eurocentrado vinculado ao patriotismo nacional imbuído nesses debates? Inclusive que essa guerra é concebida desde o nome até fontes, divergentes do modelo inventado pelo Brasil como vencedor, de contar e interpretar esse momento histórico?

Logo em seguida se propõe discutir o legado da escravidão nas Américas, sem, entretanto, questionar se foi um legado ou uma marca negativa histórica que favoreceu o processo de consolidação de um Estadonação preenchido pela negação do não-branco e posteriormente no século XX favoreceu a estrutura de teorias científicas de uma democracia racial. Nesse objeto, se parabeniza o fato de levantar a discussão da importância das ações afirmativas, tendo em vista a problemática gerada sobre esse tema na atualidade, exatamente pela falta de melhor explicitação do tema no período escolar e na consolidação de uma historiografia oficial.

Na quarta Unidade Temática denominada Configurações do mundo no século XIX, se traz ao debate o tema dos nacionalismos e das novas nações europeias, se propondo pelas habilidades, estabelecer relações entre racismo e determinismo biológico no contexto do imperialismo europeu, também conhecido como movimento neocolonialista.

Nesse aspecto, é importante analisar que como aponta Grosfoguel em citação feita nesse texto, a partir do século XVIII se inicia a transição do poder no interior da Europa para a região norte, o que solidificou a produção dos cânones científicos em apenas 5 países, e sempre sendo homens brancos. Essa transição, fortalecerá a potência da Inglaterra e condicionará na versão histórica eurocentrada a ela, a iniciativa do capitalismo industrial. Um ponto importante nesse elemento, é a proposição do estudo dos impactos nas sociedades africanas e asiáticas afetadas pela política neocolonial iniciada no século XVIII e que durará até o século XX com os movimentos de descolonização da África.

Um outro aspecto importante, é o objeto de conhecimento denominado 0 imperialismo europeu e a partilha da África, pois, esse aspecto, nos faz refletir que o imperialismo europeu nesse caso não se trata de uma novidade, mas de uma rearticulação dos países imperiais com a anexação da região ibérica como região integrante da sociedade irracional e inferiorizada como o resto do mundo desde 1492. E que esse modo de recompilar a história fortalece a estrutura racista inventada por Kant, como citado por Grosfoguel.

Ao final, se parabeniza novamente a habilidade levantada para que se identifique as tensões dos discursos civilizatórios, avaliando seus impactos negativos aos indígenas e povos negros nas Américas.

Nesse sentido, seria interessante também questionar se esses discursos foram civilizatórios, ou se na realidade foram discursos colonizadores, que ao final dos processos de colonização, se consolidaram sobre as estruturas de colonialidade do poder, ser e saber, pois, ao negar, exterminar e espoliar os povos latinoamericanos por centenas de anos, a complexidade do processo não se tornou civilizatória, e sim, condicionadora da manutenção dos elementos da colonização, entretanto, não mais por meio das estruturas monárquicas ou imperiais, mas sim pelas estruturas do saber como as universidades e escolas, pela estrutura do poder como o Estado-nação e os elementos iluministas e pela estrutura do ser por meio do racismo de Estado.

\footnotetext{
30 Sobre essas correlações recomenda-se a leitura do artigo A ameaça negra no cotidiano da elite branca: a resistência escrava ensaiando a liberdade no século XIX, de Fernando Henrique da Silva Santana. Esse trabalho consta nas referências finais desse trabalho.
} 


\section{CONCLUSÃO}

Ao refletirmos, pudemos perceber nessa curta análise, que a estruturação de uma Base Nacional Comum Curricular traz consigo diversos aspectos de invisibilização de uma história menos eurocentrada, sobretudo pela negação constante da correlação modernidade-colonialidade e pela estruturação do vislumbre da zona latinoamericana ser vista como apêndice da história europeia.

Como parabenizamos ao longo do texto, ela traz ainda elementos interessantes para uma reinterpretação histórica, porém, requer dos professores um amplo leque em sua formação para romper e apresentar aos estudantes os elementos instigantes de ruptura do padrão normativo eurocentrado.

Para que de fato seja rompido esses elementos de colonialidade no ensino, é importante que a formação de professores de História leve em consideração essa teoria crítica histórica da colonialidade, para favorecer a reinterpretação, e ainda, pesquisas que fortaleçam o surgimento de novas histórias não percebidas pelo seio eurocentrado, pois a carga do modelo padrão de ensino é necessária para novos processos de investigação da história desde outras perspectivas.

Por isso, nesse artigo trazemos algumas críticas a BNCC, pois, entendemos que é importante haver mais elementos que constituam essa construção do ensino de história no contexto escolar.

E concluímos, defendendo a liberdade de cátedra dos professores para um fortalecimento de uma história múltipla e diversa, com parâmetros curriculares, mas jamais com limitações do que pode ou não pode ser trabalhado em sala de aula, pois, entende-se que no ensino-aprendizagem deve-se levar em consideração sempre as experiências e vivências tanto dos professores como dos estudantes, para que o desinteresse de uma história distante da realidade não seja motivo de abandono escolar por parte dos estudantes e nem dos afastamentos de professores de suas funções.

\section{REFERÊNCIAS}

[1] Appel, Karl-Otto; Dussel, Enrique. Ética del discurso, ética de la liberación. Madrid: Trotta, 2005.

[2] Brasil. Ministério da Educação. Secretaria da Educação Básica. Base nacional comum curricular. Brasília, DF, 2017

[3] Garrido Aranda, Antonio. Moriscos e indios: precedentes hispánicos de la evangelización de México. México: Universidad Nacional Autónoma de México, 1980.

[4] Grosfoguel, Ramon. A estrutura do conhecimento nas universidades ocidentalizadas: racismo/sexismo epistêmicos e os quatro genocídios/epistemicídios do longo século XVI. Revista Sociedade e Estado. v. 31, no 1, 2016.

[5] Ianni, Otávio. A idéia de Brasil moderno. São Paulo: Brasiliense, 2004

[6] Maldonado-Torres, Nelson. Religion, conquête et race dans la fondation du monde moderne/colonial. In: Mestiri, Mohamed; Grosfoguel, Ramon; SOUM, El Yamine (Eds). Islamophobie dans le monde moderne. Paris: IIIT, 2008

[7] Mariátegui, José Carlos. Sete ensaios de interpretação da realidade peruana. São Paulo: Alfa Omega, 1975.

[8] Mignolo, Walter. La idea de América Latina: la herida colonial y la opción decolonial. Barcelona: Gedisa, 2007

[9] Parra, Jaime Andrés Argüello. Pedagogía decolonial: trazos para la construcción de un paradigma-otro desde la educación. Correo del Maestro, México, v.00, p.28-37, 2015.

https://www.correodelmaestro.com/publico/html5032015/capitulo4/Pedagogia_decolonial.html. Acesso em: 23 maio 2019.

[10] Quental, Pedro de Araújo. A latinidade do conceito de América Latina. Rev. Geographia, Rio de Janeiro, v.14, n.17, pp.46-72, 2012. Disponível em: <http://www.uff.br/geographia/ojs/index.php/geographia/article/view/520/338.>. Acesso em: 23 maio 2019.

[11] Santana, Fernando Henrique da Silva. A ameaça negra no cotidiano da elite branca: a resistência escrava ensaiando a liberdade no século XIX. Disponível em:

https://www.even3.com.br/Anais/historiaecontemporaneidades/83648-a-Ameaca-Negra-no-Cotidiano-da-EliteBranca--a-Resistencia-Escrava-Ensaiando-a-Liberdade-no-Seculo-XIX. Acesso em: 24 maio 2019.

[12] Quijano, Aníbal. Colonialidade do poder, eurocentrismo e América Latina. In: Lander, Edgardo. A colonialidade do saber: eurocentrismo e Ciências Sociais: Perspectivas latino-americanas, Buenos Aires: Clacso, 2005.

[13] Wallerstein, Imannuel. O sistema mundial moderno. Porto/POR: Afrontamento, 1990.404p 


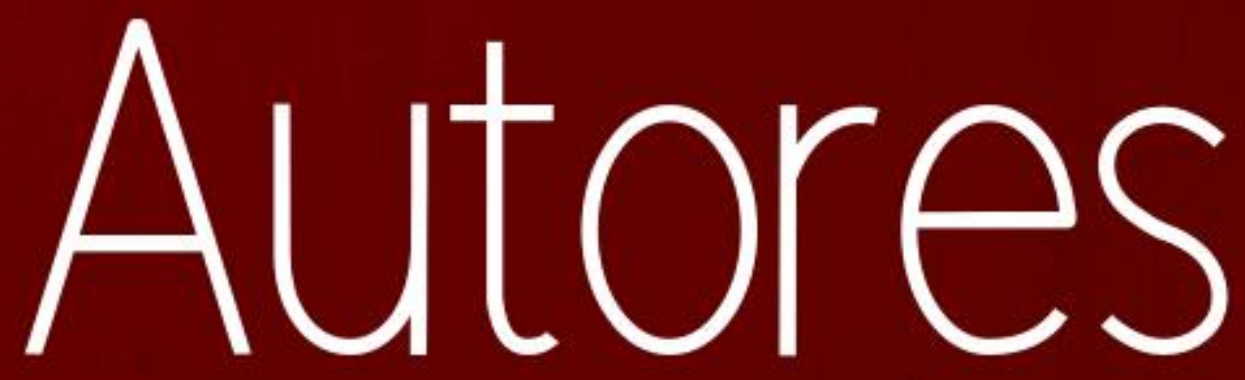




\section{ADRIANA DOROTEU DANTAS}

Possui graduação em Sistemas de Informação pelo Centro Universitário Luterano de Manaus (2008), graduação em Gestão Pública pela Universidade do Estado do Amazonas (2010) e mestrado em Mestrado em Informática pela Universidade Federal do Amazonas (2017). Atualmente é professor do Instituto Federal de Educação, Ciência e Tecnologia do Amazonas. Tem experiência na área de Ciência da Computação, com ênfase em Ciência da Computação, atuando principalmente nos seguintes temas: ambiente virtual de aprendizagem, sloodle e moodle.

\section{ADRIANA FERREIRA DE SOUZA}

Graduada em Letras Vernáculas e Pós-graduada em Metodologia da Pesquisa, Ensino e Extensão, em Educação pela Universidade do Estado da Bahia (UNEB-campus II). Também possui Pósgraduação em Gestão Escolar pela Universidade Federal da Bahia (UFBA, Salvador/BA), quando exerceu o cargo de vice-diretora no Colégio Estadual Mário Costa Filho, na cidade de Inhambupe. Professora de Língua Portuguesa Ensino Fundamental II e no Ensino médio pelas redes municipal e estadual de educação. Possui outros cursos de extensão em Sintaxe, Tópicos da Língua Falada e cursos na área de língua estrangeira (inglês e espanhol). Atualmente é mestranda do Programa Pós-Critica Cultural da UNEB- Campus II, 2018.1, em Alagoinhas/BA.

\section{AFONSO DE DEUS NUNES NETO}

Possui graduação em Administração de Empresas pela Universidade Federal do Ceará (2002). Possui MBA em Finanças pelo IBMEC. Pós-graduando em Direito tributário (FGV). Mestre em Economia pela Universidade Federal do Ceará. Atualmente é Consultor Empresarial e presta serviços a grandes empresas, gestoras e Fundos de Investimento. Professor nas áreas Administrativa-Financeira e Econômica. Consultor Financeiro com experiência nas áreas de Administração e Economia, com ênfase em Administração Financeira. Possui experiência nas área de recursos humanos, onde atuou em indústria de grande porte. Possui também experiência na área comercial e marketing, tendo se destacado como supervisor comercial em empresa de grande porte do ramo de bebidas. Especialista com experiência na área financeira, atuando em grandes empresas do ramo de bebidas e educacional, tendo recebido prêmios de destaque funcional. Experiência com consultoria financeira e empresarial no norte e nordeste do país. Trabalhou como Gerente Nacional na gestão da área de Crédito do Banco PETRA. Atualmente é empresário e presta serviços para empresas nas áreas administrativa e financeira. Ministra aulas de graduação e pósgraduação.

\section{ALANE DE SOUZA SILVA}

Graduanda em Licenciatura Plena em Geografia, pela Universidade Estadual da Paraíba (UEPB), do Centro de Humanidades, Campus III, em Guarabira PB.

\section{ANA PAULA PEQUENO MATOS}

Mestra em Gestão e Avaliação da Educação Pública pela Universidade Federal de Juiz de Fora (2017). Especialista em Gestão Educacional pela Universidade Estadual Vale do Acaraú (2014). Graduada em Ciências Biológicas pela Universidade Federal do Ceará (2000). Orientadora de célula da Coordenadoria de Avaliação e Desenvolvimento Escolar para Resultados de Aprendizagem (2019 - Atual). Desenvolve atividade didático-pedagógicas nas áreas de avaliação da aprendizagem e avaliação externa.

\section{ANTÔNIO RIBEIRO DA COSTA NETO}

Engenheiro Agrônomo graduado pela Universidade Federal do Amazonas (UFAM, 1991), Tecnólogo Florestal - modalidade na Indústria da Madeira graduado pelo Instituto Tecnologia da Amazônia (UTAM, 1998) e Engenheiro Florestal graduado também pelo UTAM (2000). Especialista em Recursos Naturais pela Universidade Federal de Viçosa, Minas Gerais (UFV/MG, 2002). Mestre em Ciências Florestais e Ambientais pela Universidade Federal do Amazonas (UFAM, 2006). 
Doutor em Desenvolvimento e Sustentabilidade Ambiental pela Universidade de Brasília (UnB, 2013), além de ter obtido aprovações em 2008 em mais dois programas de doutoramento como o de Engenharia Florestal da Universidade Federal de Lavras (UFLA-MG) e o de Clima e Ambiente do Instituto Nacional de Pesquisas da Amazônia (INPA). Exerceu funções na qualidade membro titular do Conselhos Municipal de Meio Ambiente e Sustentabilidade do Município de Manaus e da Comissão Interinstitucional de Educação Ambiental do Estado do Amazonas (CIEA-AM). Desenvolve atividades profissionais como professor de carreira no ensino básico, técnico e tecnológico do Instituto Federal de Educação, Ciência e Tecnologia do Estado do Amazonas (IFAM), com experiência docente em programas de graduação e de pós-graduação lato sensu em instituições de ensino superior. Experiência em ensino, pesquisa e extensão nas áreas de Ciências Agrárias (agronomia e engenharia florestal - ecologia florestal, silvicultura, agroecologia, áreas naturais protegidas), Ciências Ambientais (com ênfase na avaliação e na gestão ambiental, atuando principalmente nas seguintes temáticas: percepção e sensibilização ambiental, educação ambiental, gestão ambiental, avaliação de impacto ambiental, desenvolvimento local e sustentável, planejamento ambiental), Ciências Sociais Aplicadas (como turismo - turismo receptivo, turismo sustentável, turismo de natureza, turismo rural), Geociências (geoecologia, bio e fitogeografia, geografia física, geografia física, geografia agrária e geografia do turismo), além de ensino de metodologia do trabalho científico, da pesquisa e na elaboração de projetos. Atualmente, exerce as funções na gestão administrativa da Reitoria do IFAM com Pró-Reitor de Ensino, de Presidente do Conselho de Ensino, Pesquisa e Extensão do IFAM - CONSEPE e do Coordenador Geral do Comitê Gestor de Formação Inicial e Continuada de Professores da Educação Básica - COMFOR.

\section{BENILDES COURA MOREIRA DOS SANTOS MACULAN}

Doutora em Ciência da Informação pelo Programa de Pós-Graduação em Ciência da Informação, na Escola de Ciência da Informação (ECI) da UFMG/BRASIL. Atualmente, Professora Adjunto no Departamento de Organização e Tratamento da Informação, na ECI/UFMG. Participa do Grupo de Pesquisa MHTX, e do Grupo de Pesquisa RECRI. Pesquisadora no Programa de Pós-Graduação em Gestão \& Organização do Conhecimento (PPGGOC/ECI/UFMG), na linha de pesquisa Arquitetura e Organização do Conhecimento.

\section{CAUÊ ALMEIDA GALVÃo}

Doutorando no Doutorado Latino-Americano em Educação da Universidade Federal de Minas Gerais (UFMG). Mestre em Estudos Latino-Americanos (IELA-UNILA). É bacharel em História América Latina na Universidade Federal da Integração Latino-Americana (UNILA) e licenciado em História pelas Faculdades Integradas de Ariquemes (FIAR). Membro do Grupo de Estudos sobre Política Educacional e Trabalho Docente (GESTRADO) da UFMG. Tem experiências nas áreas de História da América Latina, Ensino de História, Estudos Interdisciplinares, Guerra às Drogas, Estudos Antiproibicionistas, Racismo Institucional, Seletividade Penal, Colonialidade do poder, saber e ser.

\section{CELSIANE ALINE VIEIRA ARAÚJO}

Doutoranda em Gestão e Organização da Informação pela Universidade Federal de Minas Gerais, Mestre em Gestão e Organização da Informação pela Universidade Federal de Minas Gerais, Especialista em Organização da Informação em Contexto Digital pela Universidade Federal de Minas Gerais, Bacharel em Ciência da Informação pela PUC Minas, Técnica em Processamento de Dados pela Funec/ Centec. Experiência com palestras, treinamentos e docência em ensino superior bem como atuação como Consultora em Gestão da Informação, Analista de Informação, Coordenadora de Serviços de Informação e Supervisora de Projetos. Membro do grupo de Pesquisa MHTX - Modelagem Conceitual para Organização e Representação da Informação Hipertextual, registrado no CNPq desde 2004. Foi bolsista e voluntária no Programa de Incentivo a Formação Docente - PFID do Grupo de Pesquisa Representação do Conhecimento e Recuperação da Informação - RECRI-ECI-UFMG; Foi bolsista e voluntária do Projeto Política de Periódicos para Minas Gerais e Periódicos de Alagoas. Atua no Projeto Políticas públicas para a melhoria do ensino médio: socialização científica, tradução e transferência de resultados. 


\section{DEMÓSTENES DANTAS VIEIRA}

Doutorando em Letras pela Universidade Federal do Pernambuco - UFPE; Mestre em Ciências Sociais e Humanas pela Universidade do Estado do Rio Grande do Norte - UERN; Professor de Língua Portuguesa e Literatura Brasileira no Instituto Federal de Educação, Ciência e Tecnologia do Rio Grande do Norte - IFRN.

\section{EFRAIM DE ALCÂNTARA MATOS}

Licenciado e mestre em Matemática pela Universidade Federal Rural do Semi-Árido - UFERSA; Professor de Matemática no Instituto Federal de Educação, Ciência e Tecnologia do Rio Grande do Norte - IFRN.

\section{ELIANE DOS SANTOS MALHEIROS}

Mestre em Educação pela Universidade Estadual de Londrina (UEL). Centro de Educação, Comunicação e Artes - CECA.

\section{ELIANE PICÃO DA SILVA COSTA}

Possui graduação em Ciências Biológicas - Unidade de Ensino Superior Ingá (2009).Curso Técnico em Meio Ambiente pelo Instituto Federal do Paraná (2014).Pós Graduação em Especialização Interdisciplinar em Ciências Sociais e Humanidades CEICH) Formação de Professores/ Turma 2014, UNESPAR, Campus Paranavaí. Pesquisadora do grupo de pesquisa CNPq: grupo de estudos( GECENA) sobre Educação Ambiental do PROEDUCOM. UEM. Mestre em Ensino: Formação Docente Interdisciplinar - PPIFOR - UNESPAR/ Campus Paranavaí/2016. Doutoranda da Pós Graduação em Educação para Ciência e Matemática - Universidade Estadual de Maringá. (ínício em 2017).

\section{FABRÍCIA DOS SANTOS PEREIRA}

Licencianda em Matemática pelo Instituto Federal de Educação, Ciência e Tecnologia da Paraíba. Bolsista do Programa Institucional de Bolsa de Iniciação à Docência - Pibid.

\section{FELIPE ERICK MOURA DA SILVA}

Licenciando em Matemática pelo Instituto Federal de Educação, Ciência e Tecnologia da Paraíba. Bolsista do Programa Institucional de Bolsa de Iniciação à Docência - Pibid.

\section{FERNANDA MARCONDES DE PAIVA}

Graduanda de Licenciatura em Química do Instituto Federal de Brasília.

\section{GEAM KARLO-GOMES}

Doutor e Mestre pelo Programa de Pós-Graduação em Literatura e Interculturalidade (UEPB). Professor da Universidade de Pernambuco. Orienta mestrandos no PPGFPPI. Líder do ITESI. Formador de professores de Língua Portuguesa. Entre outros trabalhos, autor de 0 Diário de leituras na escola e na universidade: estudos do gênero e práxis pedagógica, pela Mercado de Letras.

\section{GEZENIRA RODRIGUES DA SILVA}

Possui Graduação em Letras pela Universidade Federal do Ceará (2002) e título de Mestre em Linguística pela Universidade Federal do Ceará (2007). É especialista em Gestão da Educação Pública pela Universidade Federal de Juiz de Fora (2011). Possui Doutorado pelo curso de PósGraduação em Linguística da Universidade Federal do Ceará (2015). É professora titular de Língua Portuguesa da Secretaria da Educação do Ceará (SEDUC) e da Secretaria de Educação do de 
Fortaleza (SME). Atualmente exerce o cargo de orientadora da Célula de Desenvolvimento da Educação em Tempo Integral, na Coordenadoria da Educação em Tempo Integral da Secretaria da Educação do Ceará (SEDUC)

\section{GISELY CAPITULINO DA FONSECA}

Graduanda de Licenciatura em História pela Universidade Federal Rural de Pernambuco - UFRPE.

\section{GRACIANE SILVA BRUZINGA BORGES}

Bibliotecária, Mestre em Ciência da Informação pelo Programa de Pós-Graduação em Ciência da Informação (PPGGCI), da Escola de Ciência da Informação (ECI), da Universidade Federal de Minas Gerais (UFMG). Doutoranda em Gestão e Organização do Conhecimento pelo Programa de PósGraduação em Gestão e Organização do Conhecimento (PPGGOC/ECI/UFMG). Assessora em planejamento e execução de pesquisa científica. Consultora Técnicas em Arquitetura da Informação, com vistas à Gestão do Conhecimento em instituições públicas e privadas. Professora em Elaboração e Apresentação do Trabalho Científico. Especializada em Normalização Documentária e Revisão Sistemática da Literatura (RSL). Experiência em orientação para o desenvolvimento de trabalho científico. Desenvolvimento de Arquitetura da Informação para modelagem de Sistemas de Gestão de Documentos e Informação. Ampla atuação em Capacitação de Equipes voltada para a Excelência no Atendimento ao Cliente. Forte interesse na área de Organização, Gestão e Uso da Informação, com ênfase em processos de tratamento de documentação pública e corporativa. Experiência em Disseminação Seletiva da Informação (DSI); Pesquisa Especializada em Fontes de Informação e Documentação Técnica; Serviços de Referência; Gestão Documental em Arquivos Corporativos; Pesquisa Bibliográfica. Participante do Programa de Incentivo a Formação Docente (PIFD), da Pró-reitoria de Graduação (PROGRAD) da UFMG. Coordenadora da Comissão Científica do Grupo de Pesquisa Modelagem Conceitual para Organização e Representação da Informação Hipertextual (MHTX) da ECI/UFMG. Membro da diretoria de Associação dos Bibliotecários de Minas Gerais (ABMG). Professora responsável pela disciplina de Elaboração de Monografia do curso de Especialização em Ultrassonografia do Instituto Mineiro de Ultrassonografia (IMEDE/FELUMA). Professora responsável pela disciplina de Elaboração de Monografia dos cursos de Especialização em Videolaparoscopia; Videohisteroscopia e Cirurgia Vaginal e Uroginecologia, da Pós-graduação em Ginecologia Minimamente Invasiva, da Faculdade Ciência Médicas de Minas Gerais (FCM-MG/FELUMA).

\section{HERMES MACHADO FILHO}

Doutor em botânica (UFRPE), mestre em ecologia (UEPB), especialista em desenvolvimento e meio ambiente (UNIPE) e bel. Biologia (UFPB). Trabalha com florísticas em diversos ecossistemas e diferentes escalas geográficas.

\section{ISOMAR LIMA DA SILVA}

Doutorando em Engenharia e Tecnologia Espaciais, área de concentração em engenharia e gerenciamento de sistemas espaciais no Instituto Nacional de Pesquisas Espaciais - INPE. Mestre em Informática linha de pesquisa inteligência artificial. Especialista em engenharia de redes e sistemas de telecomunicações. Bacharel em sistemas de informação. Tem experiência na área de Ciência da Computação com ênfase em Redes de Computadores.

\section{JANIELE PEREIRA DA SILVA SANTOS}

Graduanda em Licenciatura Plena em Geografia, pela Universidade Estadual da Paraíba (UEPB), do Centro de Humanidades, Campus III, em Guarabira PB. 


\section{JEANE DOS SANTOS SILVA VIANA}

Mestre em Educação, com área de concentração em Educação Social, pela Universidade Federal do Mato Grosso do Sul - Campus do Pantanal (UFMS - CPAN). Especialista em Educação Física Escolar pela Faculdade do Noroeste de Minas (FINOM). Licenciada em Educação Física pela Universidade Estadual do Sudoeste da Bahia - Campus Jequié (UESB). Pesquisadora do Grupo de Estudos em Ciências Humanas (GEHU) do IFBaiano - campus Santa Inês e do Grupo de Estudo e Pesquisa em Políticas Educacionais, Formação docente e Educação (GEPEFE) da UFMS - CPAN. Área de atuação: Ciência Política; Políticas Educacionais; Educação Física Escolar. Professora do Instituto Federal de Educação, Ciência e Tecnologia Baiano - Campus Santa Inês (IF Baiano - SI).

\section{JOSÉ ALVES FERREIRA NETO}

Possui graduação em História pela Universidade Federal do Ceará (2008) e especialização em Gestão Escolar e Coordenação Pedagógica pela Faculdade Sete de Setembro - FA7 (2017). Atualmente atua na Secretaria da Educação Básica do Ceará (SEDUC-CE) na Coordenadoria de Avaliação e Desenvolvimento Escolar para Resultados de Aprendizagem - COADE como Assessor Técnico da Célula de Avaliação e Desempenho Acadêmico - CEADE.

\section{JOSÉ JORGE DE SOUZA SILVA}

Licenciando em Matemática pelo Instituto Federal de Educação, Ciência e Tecnologia da Paraíba. Bolsista do Programa Institucional de Bolsa de Iniciação à Docência - Pibid.

\section{JOSEFA MARIA DOS SANTOS}

Doutoranda em linguística pela Universidade Federal de Alagoas- UFAL. Mestra em letras pelo PROFLETRAS na Universidade de Pernambuco, campus Garanhuns. Professora da educação básica da rede estadual e municipal de Pernambuco. Desenvolve pesquisas sobre gênero, discurso e redes sociais digitais.

\section{JOSENILDO PINHEIRO DA SILVA}

Licenciado em Letras pela Universidade Federal do Rio Grande do Norte - UFRN; Especialista em Literatura e Ensino pelo Instituto Federal de Educação, Ciência e Tecnologia do Rio Grande do Norte - IFRN, onde também atua como Professor de Língua Portuguesa e Literatura Brasileira.

\section{JOSIMERE MARIA DA SILVA}

Mestra em Literatura e Interculturalidade pela Universidade Estadual da Paraíba. Especialista em Linguística Aplicada a Práticas Discursivas pela Faculdade Frassinetti do Recife. Licenciada em Letras (Língua Portuguesa, Língua Inglesa e suas Literaturas. Professora do Instituto Federal de Educação, Ciência e Tecnologia de Alagoas - Campus Piranhas.

\section{KEITE MARIA SANTOS DO NASCIMENTO LIMA}

Mestra em História Social pela Universidade Federal da Bahia, especialista em História Regional e Local pela Universidade Estadual de Santa Cruz e licenciada em História pela Universidade do Estado da Bahia (Campus II). Atualmente compõe o corpo docente da Faculdade Santíssimo Sacramento em Alagoinhas (BA). Ocupou o cargo de Diretora Pedagógica da Secretaria Municipal de Educação do município de Alagoinhas-BA (2017-2019) e, atualmente, ocupa o cargo de Subsecretária Municipal. Possui certificação internacional PECC® - Professional Executive Coach Certification. Tem interesse por pesquisas relacionadas ao trinômio História/Educação/Gestão. 


\section{LETÍCIA DOS SANTOS MIRANDA}

Estudante do curso de graduação em Biblioteconomia da Universidade Federal de Minas Gerais (UFMG). Possui interesses nas temáticas: Organização e representação do conhecimento e da informação; Sistemas de organização do conhecimento; Indexação; Mapas conceituais; Modelagem conceitual; tecnologia da informação; Políticas de Indexação; Indexação de Imagens; Padrão de metadados (Dublin Core, MARC21). Integrante do Grupo de Pesquisa Representação do Conhecimento e Recuperação da Informação - RECRI/UFMG.

\section{LIC. LEONARDO RODRIGUES DE ALMEIDA}

Graduando em Licenciatura em Ciências da Computação - UFPB Campus IV - Rio Tinto.

\section{LUCIANO NERY FERREIRA FILHO}

Professor da Rede Pública Estadual de Ensino do Ceará. Licenciado em Biologia pela Universidade Estadual do Ceará (UECE). Especialista em Gestão da Educação Pública pela Universidade Estadual do Ceará (UECE). Especialista em Gestão e Avaliação da Educação Pública pela Universidade Federal de Juiz de Fora (UFJF). Mestre em Gestão e Avaliação da Educação Pública pela Universidade Federal de Juiz de Fora (UFJF). Coordenador por 3 anos da Coordenadoria de Avaliação e Acompanhamento da Educação da SEDUC/CE. Atualmente é Coordenador da Coordenadoria da Educação em Tempo Integral da SEDUC/CE

\section{LUCIENE MARIA PATRIOTA}

Possui graduação em Licenciatura plena em Letras pela Universidade Federal da Paraíba (1993), mestrado em Mestrado em Linguagem e Ensino pela Universidade Federal de Campina Grande (2006) e doutorado em Lingüística pela Universidade Federal da Paraíba (2011). Atualmente é professor adjunto da Universidade Federal de Campina Grande. Tem experiência na área de Letras, com ênfase em Letras, atuando principalmente nos seguintes temas: ensino, gíria, livro didático, variação e sala de aula.

\section{LUCILA AKIKO NAGASHIMA}

Possui graduação em Química pela Universidade Estadual de Maringá (1977), graduação em Ciências de Primeiro Grau pela Universidade Estadual do Paraná (1972), mestrado em Engenharia Química pela Universidade Estadual de Maringá (2004) e doutorado em Engenharia Química pela Universidade Estadual de Maringá (2009). Professora aposentada da Universidade Estadual do Paraná. Atua como docente no programa de pós-graduação strictu sensu (mestrado acadêmico em formação docente interdisciplinar).nas disciplinas - 0 Ensino de Ciências e os conhecimentos básicos comuns para o ensino-aprendizagem e 0 ensino de Física e Química na Educação Brasileira.Tem experiência na área de Química, e a pesquisa é essencialmente na área de Saneamento Ambiental, em tratamento de efluentes com Reagente Fenton e com coagulante orgânico a base de tanino. Também atua na área gerenciamento de resíduos sólidos.

\section{LUIZ FERNANDES DA COSTA}

Professor de Matemática do curso de Administração da Faculdade Machado de Assis (FAMA - RJ). Aposentado na Rede Pública Estadual pelo Instituto de Educação Sarah Kubistchek (IESK), sendo também pesquisador da história da instituição. Mestre em Educação pela Universidade Estácio de Sá (UNESA) e atualmente em fase final do doutorado em Epistemologia e História da Ciência pela Universidad Nacional Tres de Febrero (Buenos Aires - Argentina).

\section{MARIA CLARA GOMES DA SILVA}

Estudante do ensino médio integrado ao curso técnico em Controle Ambiental pelo IFPB, trabalhando com pesquisa em florística. 


\section{MARIA DE FÁTIMA PEREIRA DA SILVA}

Graduada em Ciências com Habilitação em Matemática pela Universidade Federal de Campina Grande (2005). Graduada em Enfermagem pela Universidade Federal de Campina Grande (2017). Especialização em Agroecologia pela Universidade Federal da Paraíba (2008). Especialização em Educação Matemática pela Faculdade Integrada de Patos (2009). Técnica em Enfermagem pela Escola Técnica Maria Letícia Botelho, atual Escola Técnica de Saúde de Cajazeiras da Universidade Federal de Campina Grande (2002). Pós-graduanda em Docência do Ensino Superior. Atualmente é professora de matemática - EMEF Crispim Coelho e supervisora do Programa Institucional de Bolsa de Iniciação à Docência - Pibid. Tem experiência na área de Matemática e Enfermagem.

\section{MARIANA FREITAS CANIELO DE CARVALHO}

Mestranda em Ciência da Informação pelo PPG-GOC ECI/UFMG, graduada em biblioteconomia pela Universidade Federal de Minas Gerais. Atua como analista do projeto BPM Acadêmico: modelagem de processos administrativos e fluxos informacionais, com pesquisas voltadas para mapeamento e modelagem de processos e fluxogramas informacionais. Atuou como bolsista voluntária no Programa de Incentivo a Formação Docente - PFID do Grupo de Pesquisa Representação do Conhecimento e Recuperação da Informação - RECRI-ECI-UFMG; bolsista de Iniciação Científica no projeto BPM Acadêmico; foi monitora na disciplina de sistema de Classificação Decimal Dewey (CDD) de 2017 a 2018, no curso superior de biblioteconomia da UFMG; e no período entre 2015 a 2017 realizou estágio remunerado na biblioteca do centro Cultural SESIMINAS em Belo Horizonte.

\section{MARINALVA DA SILVA FERREIRA}

Mestra em Ensino pela Univates, é especialista em Docência da Educação Superior, Gestão Educacional, Tecnologia da Informação para Educadores e Gestão de Políticas Públicas em Gênero e Raça, possui Licenciatura Plena em Pedagogia pela Universidade Federal do Maranhão (2002). Atuou como Professora Substituta na Universidade Federal do Maranhão, atualmente trabalha como pedagoga em Escola da Rede Municipal em Imperatriz e na Secretaria Municipal de Educação de Davinópolis.

\section{MARIO CEZAR ALVES FERREIRA}

Mestre em Ensino de Ciências Humanas Sociais e da Natureza pela Universidade Tecnológica Federal do Paraná, UTFPR, Brasil. Programa de Pós-Graduação em Ensino de Ciências Humanas Sociais e da Natureza - PPGEN. Londrina/PR. E mail: mariocezara@hotmail.com.

\section{MARLI TERESINHA QUARTIERI}

Possui graduação em Ciências - Licenciatura de 1ํㅡ Grau pela Faculdade de Educação Ciências e Letras do Alto Taquari (1987), graduação em Matemática - Licenciatura Plena pela Faculdade de Educação Ciências e Letras do Alto Taquari (1989), especialização em Educação Matemática pela Universidade de Santa Cruz do Sul (1998), mestrado em Matemática Aplicada pela Universidade Federal do Rio Grande do Sul (2004), doutorado em Educação pela Universidade Vale do Rio dos Sinos - RS. Atualmente é professora da Universidade do Vale do Taquari - UNIVATES, atuando nos cursos de graduação e de Pós-graduação (Mestrado em Ensino de Ciências Exatas e no Programa em Ensino). Bolsista de Produtividade em Pesquisa 2 do CNPq. Tem experiência na área de Ciências Exatas, com ênfase no Ensino de Matemática, atuando principalmente nos seguintes temas: modelagem matemática, investigação matemática, formação de professores, uso de tecnologias no ensino de Matemática.

\section{MIRIAM INES MARCHI}

Possui graduação em Química Industrial pela Universidade de Santa Cruz do Sul (1994), mestrado em Química pela Universidade Federal de Santa Maria (1998) e doutorado em Química pela Universidade Federal de Santa Maria (2003). Atualmente é professora titular da Universidade do Vale do Taquari - UNIVATES. Atua, principalmente, nas seguintes linhas de pesquisa: Tecnologias, 
metodologias e recursos didáticos para o ensino e Formação de Professores e Práticas Pedagógicas no Ensino.

\section{PATRÍCIA ARAÚJO DE SOUSA}

Possui formação em Magistério de Nível Médio Normal, concluída em 2015, pela Escola Normal Estadual Oswaldo Trigueiro de Albuquerque Mello, em Alagoa Grande - PB. Atualmente é graduanda em Licenciatura Plena em Pedagogia, pela Universidade Estadual da Paraíba (UEPB), do Centro de Humanidades, Campus III, em Guarabira - PB.

\section{PAULO RICARDO FERREIRA PEREIRA}

Mestrando do Programa de Pós-graduação em Linguagem e Ensino (PPGLE), da Universidade Federal de Campina Grande (UFCG). Graduado em Letras - Língua Portuguesa, pela (UFCG), e formado pela instituição de ensino profissional SENAI. Na graduação, foi aluno bolsista dos projetos PIBIC (PIBIC 2016-2017/CNPq/UFCG), PIVIC (2017-2018/CNPq/UFCG) e PIBIC (20182019/CNPq/UFCG), assim como professor voluntário de gramática e redação do Pré-Vestibular Solidário (PVS), da UFCG, no período de 2017 a 2018. Tem interesse em: letramento, currículo, formação de professor e ensino-aprendizagem de escrita.

\section{PEDRO FELIPE DE LIMA HENRIQUE}

Licenciado em Letras pela Universidade Federal do Rio Grande do Norte - UFRN; Especialista em Literatura e Ensino pelo Instituto Federal de Educação, Ciência e Tecnologia do Rio Grande do Norte - IFRN, onde também atua como Professor de Língua Portuguesa e Literatura Brasileira.

\section{PRISCILA SANTOS FIDELIS DA SILVA}

Estudante de tecnólogo em gestão ambiental (IFPB) com curso na área de assistente administrativo e digitação (CCI), pesquisando sobre diversidade florística.

\section{PROF. DR. MARIANO CASTRO NETO}

Licenciatura em pedagogia pela Universidade Tuiuti do Paraná (1996). Mestrado em Ergonomia (2000) e Doutorado (2006) em Mídia e Conhecimento, ambos pela Universidade Federal de Santa Catarina. A tese conquistou dois prêmios; um pelo MEC/CNPQ/CAPES/SEED/PAPED, e o de EXCELÊNCIA em EaD da ABED/2007 obtendo, entre 93 trabalhos inscritos, o 1ำ lugar na categoria Pesquisa. Vice Coordenador e Professor permanente do Programa de Pós-Graduação em Políticas Públicas, Gestão e Avaliação da Educação Superior - MPPGAV . Professor Adjunto IV lotado no Departamento de Educação do Campo do Centro de Educação da Universidade Federal da Paraíba. Campus I - Cidade Universitária - João Pessoa / PB / Brasil. Áreas de interesse: processos ensinoaprendizagem realizados por meio de tecnologias digitais, hipermídia adaptativa, aspectos ergonômicos de acessibilidade, inclusão digital nas escolas do campo, agentes pedagógicos e teoria da atividade.

\section{RAQUEL FIGUEIREDO BARRETTO}

Professora do Centro Universitário Fanor Wyden. Possui graduação em Letras (2001) e Especialização em Ensino de Língua Portuguesa (2005) pela Universidade Estadual do Ceará, Mestrado em Saúde Coletiva (2008) pela Universidade de Fortaleza (UNIFOR).

\section{RITA BRAGA SOARES DA SILVA}

Estudante do ensino técnico em Controle Ambiental integrado ao ensino médio no Instituto Federal da Paraíba. Participa de projetos de pesquisa com levantamento florístico e faz trabalhos voluntários na área ambiental. 


\section{RODINEY MARCELO BRAGA DOS SANTOS}

Licenciado em Matemática pela Universidade Estadual do Ceará - UECE (2003), Licenciado em Pedagogia pelo Centro Universitário Internacional - UNINTER (2019), Especialista em Gestão Escolar pela UECE (2006), Especialista em Educação a Distância pelo Serviço Nacional de Aprendizagem Comercial - SENAC (2007), Mestre pelo Programa Interdisciplinar em Logística e Pesquisa Operacional da Universidade Federal do Ceará - UFC (2011), na Linha de Logística e Sustentabilidade e Doutor pelo Programa em Rede de Biodiversidade e Biotecnologia da Amazônia Legal da Universidade Federal de Roraima - UFRR (2017), na Linha de Gestão Logística. Atualmente é professor do Instituto Federal de Educação, Ciência e Tecnologia da Paraíba - IFPB, com atuação no Curso de Licenciatura em Matemática e Especialização em Matemática. Desenvolve atividade de orientação de estágio supervisionado. Coordenador do Subprojeto de Matemática do Programa Institucional de Bolsa de Iniciação à Docência - Pibid. Pesquisador do Grupo Cajazeirense de Pesquisa em Matemática vinculado ao CNPq/IFPB. Atuou como professor efetivo do Instituto Federal de Educação, Ciência e Tecnologia de Rondônia - IFRO (2012-2013). Atividades desenvolvidas na Área de Educação Matemática, atuando com os temas: Formação Inicial e Continuada de Professores e Metodologias para o Ensino e Aprendizagem da Matemática.

\section{SABRINA KARINA DA SILVA SOUSA}

Licencianda em Matemática pelo Instituto Federal de Educação, Ciência e Tecnologia da Paraíba. Bolsista do Programa Institucional de Bolsa de Iniciação à Docência - Pibid.

\section{TAMIRES DOS SANTOS CIRILO DINIZ}

Graduanda em Licenciatura Plena em Geografia, pela Universidade Estadual da Paraíba (UEPB), do Centro de Humanidades, Campus III, em Guarabira PB.

\section{THAÍS HELENA CHAVES DE CASTRO}

Professora adjunta da Universidade Federal do Amazonas, onde orienta alunos de graduação, mestrado e doutorado. Concluiu o Doutorado em Informática na PUC-Rio (2011), durante o qual fez o programa Doutorado Sanduiche na University of Edinburgh (2009-2010). Seu foco de pesquisa é na elucidação de processos de design inclusivo e avaliação de artefatos computacionais interativos, utilizando técnicas de Inteligência Artificial aplicadas a Informática na Educação, Interação Humano-Computador e Interação Multimodal, com ênfase em Acessibilidade. Na medida em que busca técnicas inovadoras em computação para a inclusão de pessoas com deficiência, o foco de pesquisa também permeia a área de Ensino de Ciências e Matemática. Ela também é interessada em metodologias e técnicas para Aprendizagem de Programação. Tem coordenado e participado de vários projetos financiados pela FAPEAM (Fundação de Amparo à Pesquisa do Amazonas), CNPq e Capes. Atualmente é docente do Programa de Pós-Graduação em Informática da UFAM e coordenadora do Programa de Pós-Graduação em Ensino de Ciências e Matemática também da UFAM. Além disso, é vice-coordenadora da Comissão Especial de Informática na Educação da Sociedade Brasileira de Computação, é vice-coordenadora da Comissão Especial em Sistemas Colaborativos da Sociedade Brasileira de Computação, é revisora da RBIE e membro do comitê de programa dos eventos: SBSC, IHC, SBIE e FIE, dentre outros.

\section{THAMYRIS MARIANA CAMAROTE MANDÚ}

Professora Adjunto A da Universidade Federal da Paraíba, vinculada ao Departamento de Habilitações Pedagógicas do Centro de Educação. Doutora em Educação pelo Programa de PósGraduação em Educação da UFPE (2017). Possui mestrado em Educação pela UFPE (2013) e graduação em Pedagogia, também pela UFPE (2010). Tem experiência de ensino na área de Gestão Educacional e Políticas Educacionais. Possui experiência de pesquisa na área de Formação de Professores, principalmente nos seguintes temas: curso de pedagogia, representações sociais, identidade, currículo e prática pedagógica. 


\section{YASMIN COELHO FIGUEIREDO MANFREDO}

Possui graduação em Letras pela Faculdade Estadual de Educação, Ciências e Letras de Paranavaí (1993). Tem experiência na área de Letras, com ênfase em Língua Portuguesa, Literatura e Língua Inglesa. Professora PDE formada em 2011 com especialização em Língua Inglesa. Mestranda no Programa de Pós-Graduação Mestrado em Ensino: Formação Docente Interdisciplinar-PPIFOR na UNESPAR- Campus de Paranavaí. Professora estatutária concursada desde 1996. 


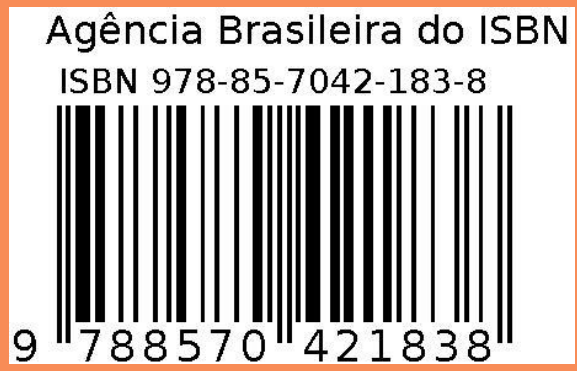

